Historic, Archive Document

Do not assume content reflects current scientific knowledge, policies, or practices. 

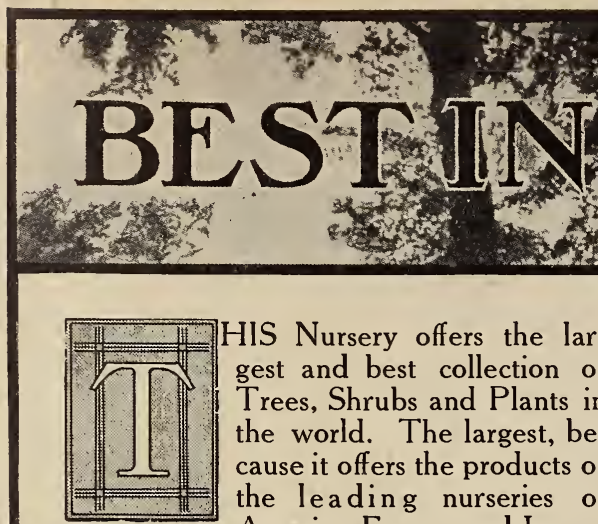

HIS Nursery offers the largest and best collection of Trees, Shrubs and Plants in the world. The largest, because it offers the products of the leading nurseries of America, Europe and Japan; the best, because, in addition to its specialties, which it grows, expert knowledge is used in selecting stock in the best nurseries. This business, established 20 years, has given such satisfaction that there are but few nurserymen and plantsmen who handle so great a variety or quantity of stock.

Our business is a unique one. As growers, we grow only specialties, and endeavor to grow these better than they can be obtained elsewhere. When anything else is ordered, we buy it direct from the very best grower of that particular tree, shrub or plant, wherever he may be found, in America, Europe, or Japan. By combining the orders of a great many, we obtain very low prices, and give our customers the benefit by charging only a moderate profit for our services.

In connection with our office, we have extensive Experimental Grounds, in which all novelties, rarities and standard varieties are tested. To avoid misunderstandings, customers are requested to read terms on second page before ordering.

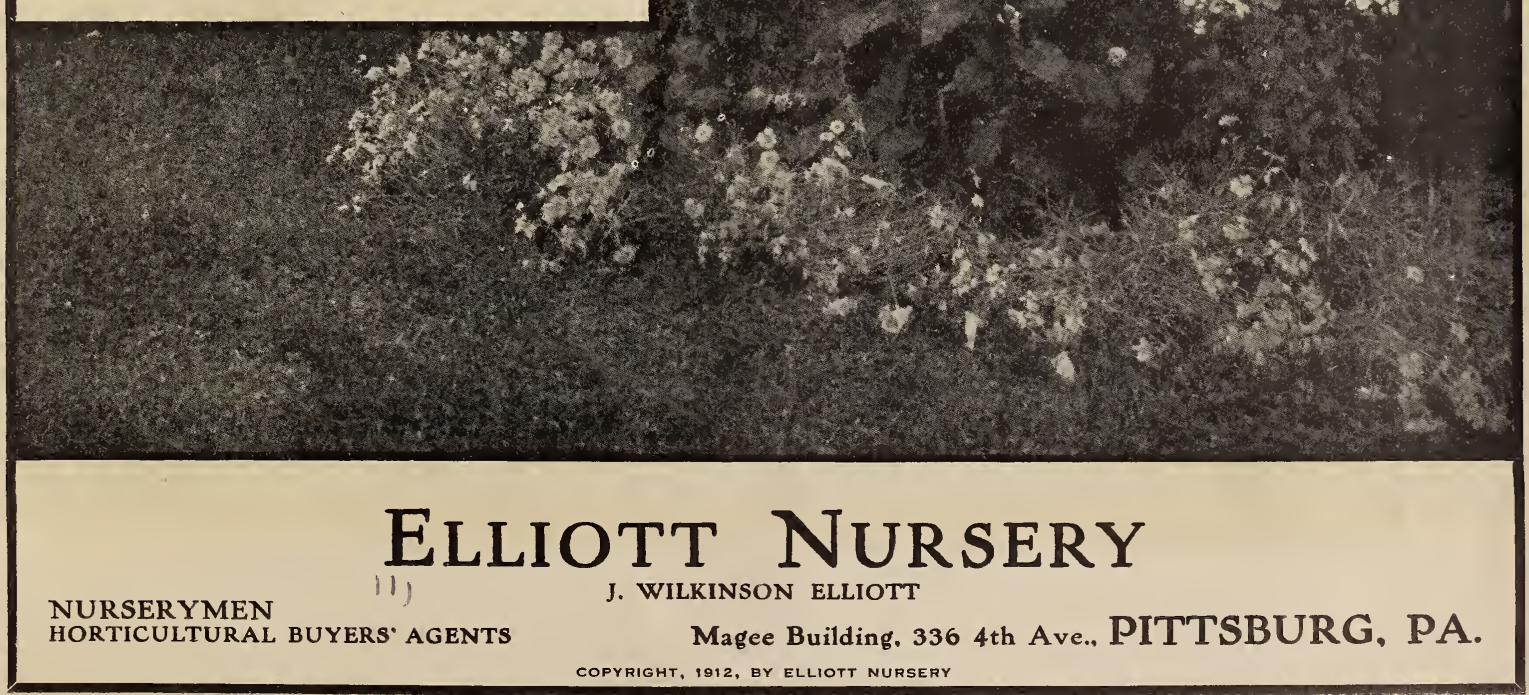




\section{Terms of Payment}

Our terms of payment are invariably cash on delivery, which does not mean that we ship C. O. D., as we will not do so under any circumstances. We deliver the goods and mail bills at the same time, and expect payment within a few days. People unknown to us will please send references with their order.

\section{NO AGENTS EMPLOYED}

It has been reported to us that swindlers have represented themselves as our agents in various parts of the country. We employ no agents whatever, but do an EXCLUSIVELY RETAIL BUSINESS DIRECT WITH OUR CUSTOMERS.

\section{PRICES}

Prices in this list are made subject to stock offered being unsold when ordered.

\section{GUARANTEES}

We guarantee all nursery stock furnished by us to be first-class, true to name, and delivered in good condition when shipped by express, and will replace free any stock spoiled in transit. Stock is shipped by freight at purchaser's risk, unless otherwise agreed upon.

WE DO NOT GUARANTEE STOCK TO GROW, OR RESULTS IN ANY WAY. NO COMPLAINT WILL BE ENTERTAINED THAT IS NOT MADE IMMEDIATELY UPON RECEIPT OF STOCK.

There are so many causes for failure over which we have no control that we can assume no responsibility after stock is delivered in good order. Poor soil, unfavorable weather, ignorant or careless culture-all contribute to failure and all are beyond our control.

A Catalogue as comprehensive as this must of necessity offer some varieties of difficult culture, and, when these are ordered, we presume the people ordering them have the knowledge needed for their culture. Successful gardening requires knowledge, enthusiasm and perseverance, and these we cannot supply, but we shall be glad to make selections for the "can't-be-killed" class of plants for people who wish them.

\section{IMPORT ORDERS}

Import orders are taken subject to failure of crops.

\section{SHIPPING DIREGTIONS}

Please give explicit shipping directions, stating whether stock is to be shipped by freight or express, and by what route. Early orders for trees, shrubs and bulbs can be generally shipped safely by freight, but shipments will be sent by freight at the risk of the purchaser only. 


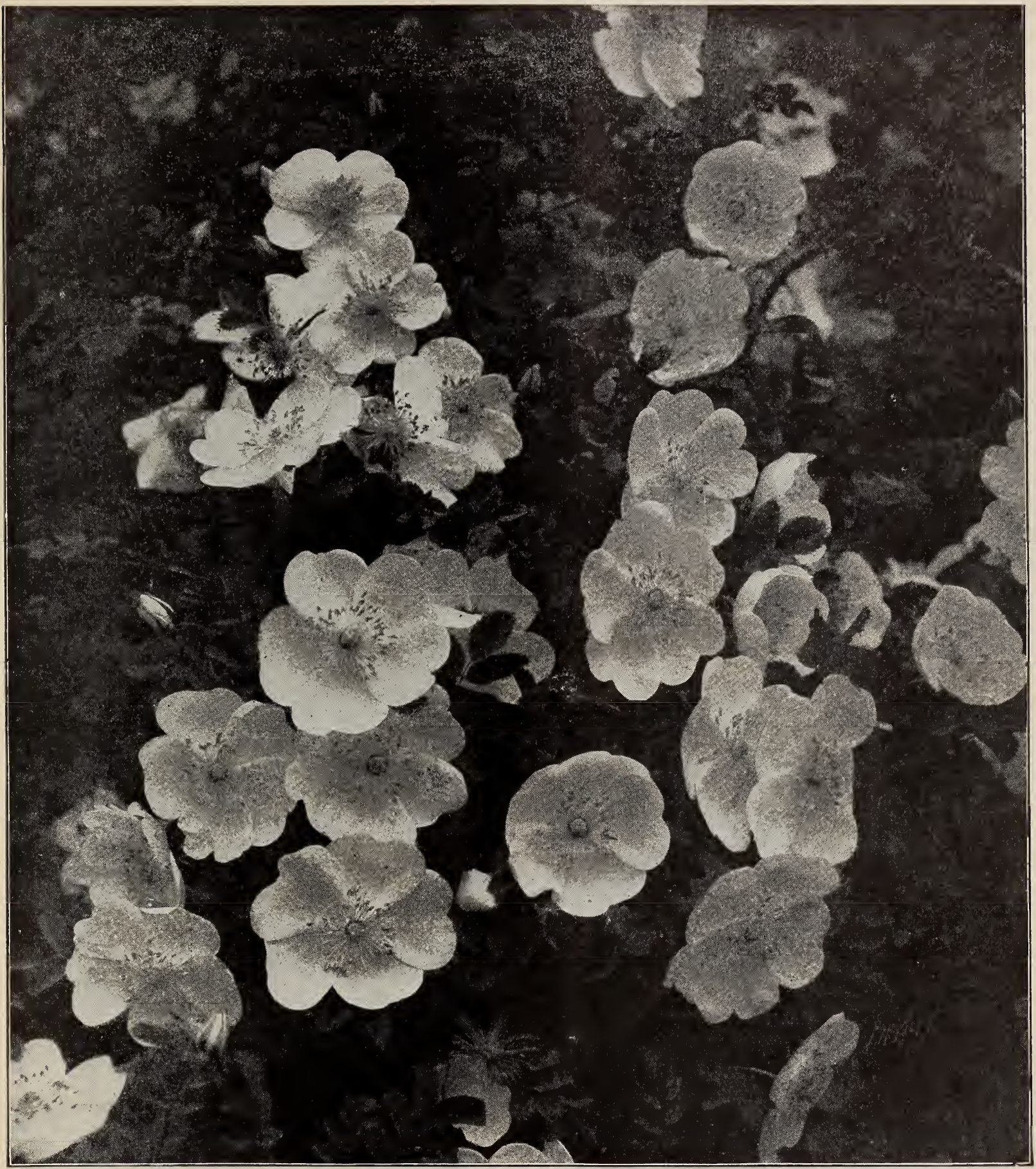

\section{Rosa Spinosissima LIMITED stock}

We have again succeeded in getting a stock of this rare and exquisitely beautiful single hardy Rose. In our opinion it is one of the most beautiful things on earth, and is surpassed only by the Cherokee Rose of the South, which is not hardy in our climate. This Rose grows to 4 or 5 feet; compact and bushy in habit, and in June is covered with large yellowish single white flowers of indescribable beauty. Planted in groups in the shrubbery, it produces an effect to which no description can do justice. 75 cts. each, $\$ 8$ per doz.. 


\section{NOVELTIES AND SPECIALTIES}

Our experience has been that not one horticultural novelty in ten is worth growing, and we have made it a rule never to offer any new tree, shrub or plant until it has been thoroughly tested; consequently, the noveltics of the season are never found in our catalogue.

\section{Pronia festiva maxima}

Of this glorious white Peony we now have a stock of over ten thousand plants, and to induce people to plant it in quantity, we have decided to offer it at a specially low price. It is the most satisfactory Peony in cultivation, and can not be surpassed either for cut-flowers or for decorative effect in the garden. Very large, pure white flower, with a few blood-red stains in the center; tall stalks, beautiful foliage and very freeflowering. Strong undivided clumps, $\$ 2$ each, $\$ 20$ per doz., $\$ 150$ per $100 ; 25$ at the 100 rate. Strong-flowering plants, 75 cts. each, $\$ 8$ per doz., $\$ 50$ per $100 ; 25$ supplied at the 100 rate. Small plants, 30 cts. each, $\$ 3$ per doz., $\$ 20$ per $100 ; 25$ supplied at the 100 rate.

\section{Hydrangea, Standard}

Of the well-known hardy Hydrangea we have secured some fine standards. 50 cts. each.

\section{Hydrangea arborescens grandiflora}

This is a splendid improvement of our native Hydrangea. It has large panicles of pure white flowers ranging from 6 to 10 inches across and is in bloom from July until frost, and is undoubtedly one of the most valuable shrubs introduced for many years. It will thrive in either sun or shade. 30 ets. each, $\$ 3$ per doz. Extra-strong plants, 50 cts. each, $\$ 5$ per doz.

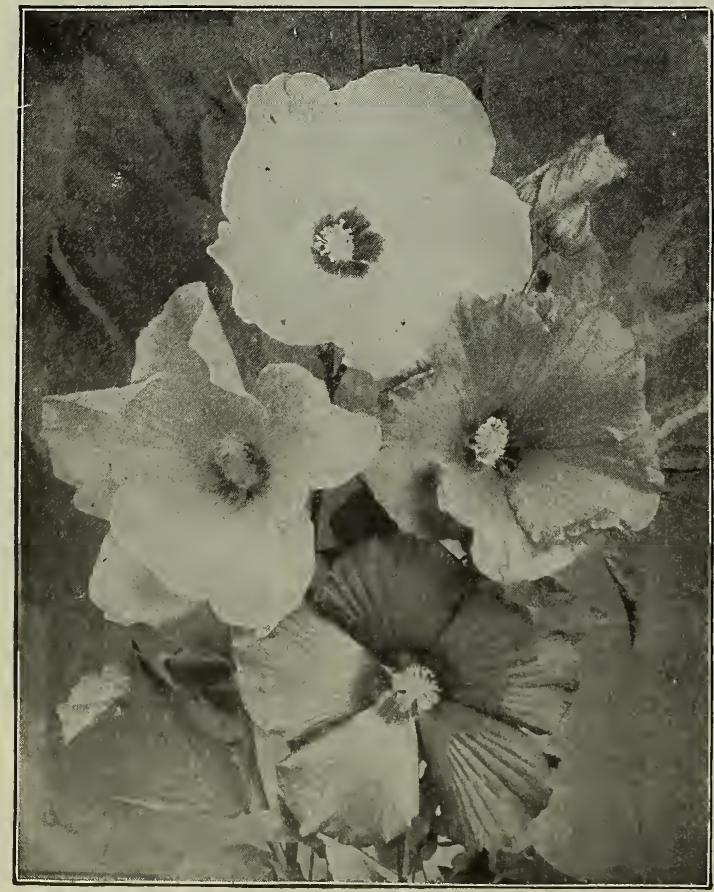

"Meehan's Mallow Marvels"

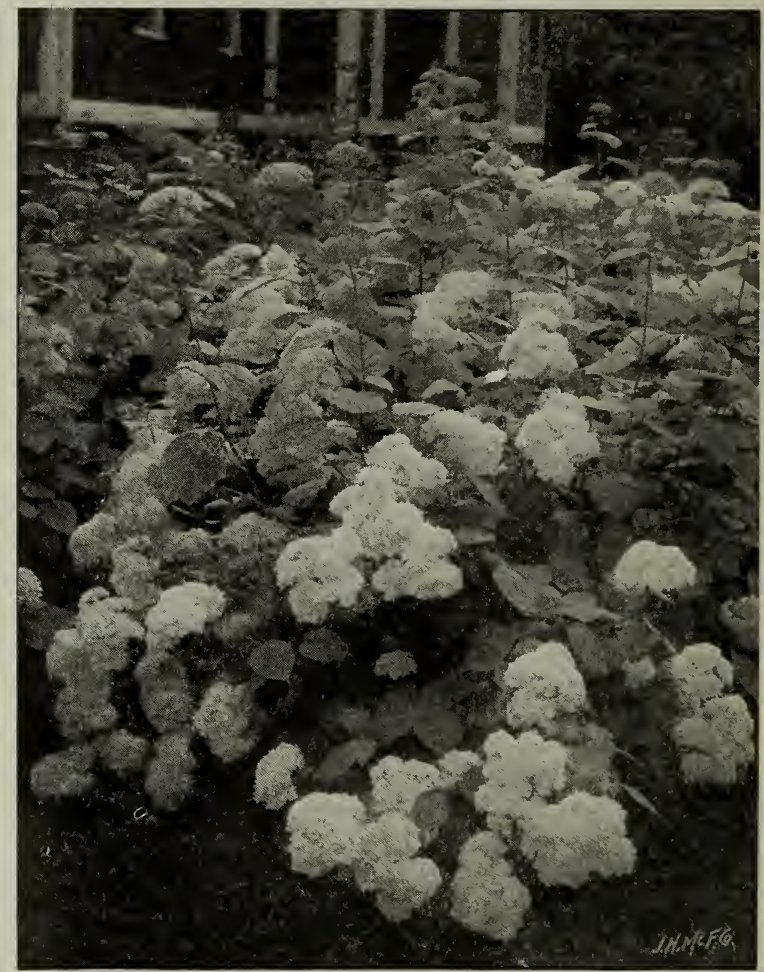

Hydrangea arborescens grandiflora

\section{Heuchera, "Rain of Fire"}

We have thoroughly tested this new Heuchera and find it one of the most desirable hardy plants introduced in many years. It has the same habit and foliage as Heuchera sanguinea, but the color is a more brilliant crimson, and five or six times as many flowers are produced. Blooms in May, and when in bloom is about 15 inches in height. The flowers last for almost three months, which makes it very desirable. 25 cts. each, $\$ 2.50$ per doz.

\section{"Meehan's Mallow Marvels"}

We have thoroughly tested this new Hibiscus and have found it very beautiful and desirable in every respect. It is a hybrid of the well-known Hibiscus Moscheutos and the tropical Hibiscus so largely grown in Florida, and combines the hardiness of the former with the brilliant colors of the latter. It makes a large bush, and produces its immense, brilliant flowers freely from July until frost. The white-flowered varieties are very nearly like the white variety of Hibiscus Moscheutos. In separate colors selected, red, crimson and pink, 60 cts. each, $\$ 6$ per doz. Mixed colors, unlabeled, 15 cts. each, $\$ 1.50$ per doz. 


\section{A Splendid Evergreen Vine, Euonymus Radicans}

This vine is in no sense a novelty, as it has been well and favorably known by a few people for many years. For covering stone, brick or cement walls, it is the best vine that can be used, and it is the only evergreen vine that is reliably hardy in this climate. The leaves are small, of a rich lustrous green and quite as beautiful in winter as in summer. The house in Erie, of which we show an illustration, we think is the most effective vine-clad house we have ever seen. The climate of Erie, which is on the lake, is a very severe one. This vine is very slow-growing for two or three years, but after it becomes well established it grows more rapidly and it is well worth waiting for. This Euonymus can also be used instead of dwarf box, which is not reliably hardy north of Washington, for garden or border edging or small hedges, and nothing is more effective for the purpose. For this purpose it should be planted 6 inches apart and kept sheared, and treated in this way it will make as neat an edging or miniature hedge as one could wish. 20 cts. each, $\$ 2$ per doz., $\$ 14$ per 100 . Extra-strong plants, 30 cts. each, $\$ 3$ per doz., $\$ 20$ per 100 . Can be planted until midsummer.

\section{Azalea Canescens}

We consider this the best of our native Azaleas. It is the earliest to bloom, and its pink flowers are of a brighter color than any other sort, and in fragrance it far surpasses them all, having the same odor as the common grass pinks. We have a good stock of this fine shrub in transplanted stock. $\$ 1$ each, $\$ 10$ per doz.

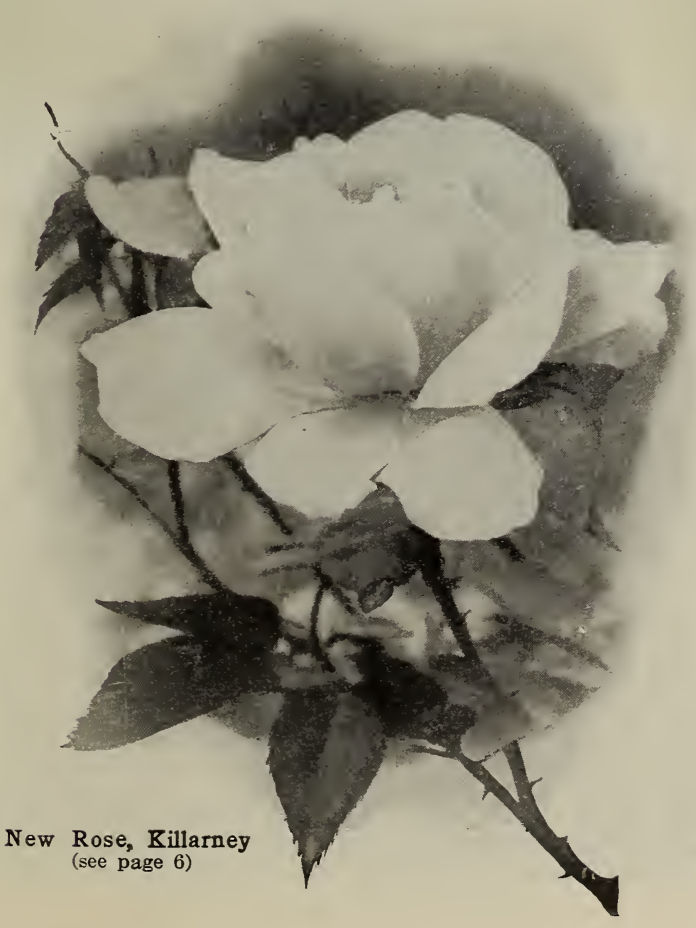

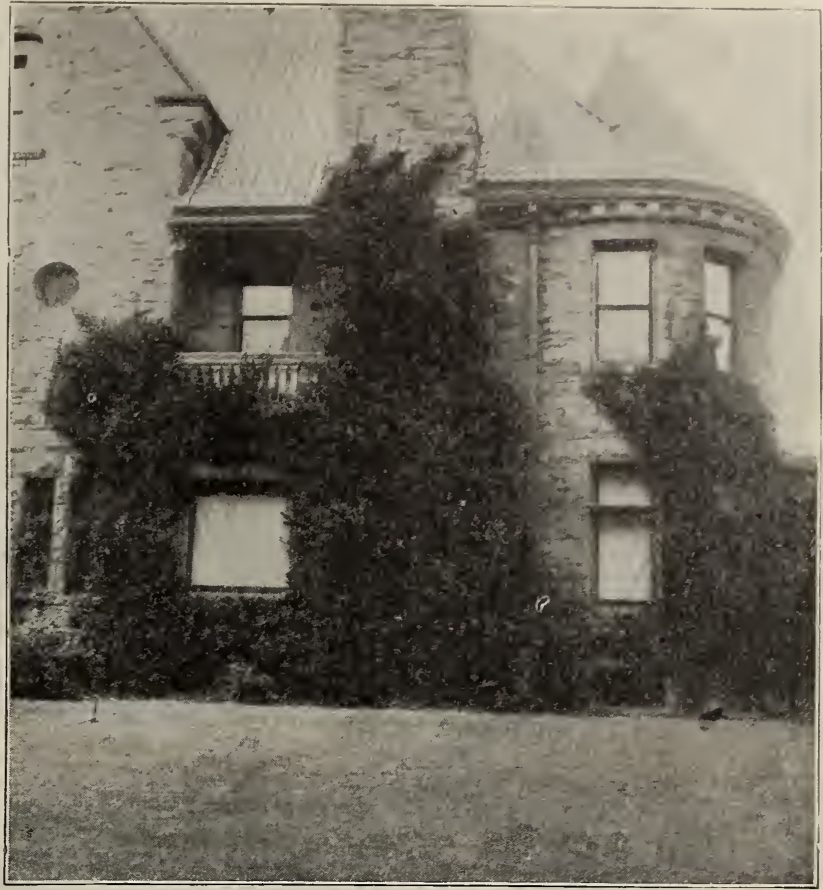

Euonymus radicans on stone house in Erie

\section{Stenanthium Robustum (MOUNTAIN FEATHER FLEECE)}

This remarkably hardy perennial is without doubt one of our best new introductions, and may be classed with the showiest of all herbaceous plants. As the buds begin to unfold, they are quite upright, and of a light green tinge, gradually becoming whiter until at last they burst forth into a veritable snowbank of drooping, fleecy bloom of the purest white, the panicles often 2 to 3 feet long. After several weeks, the flowers as they ripen, turn to shades of pink and purple. It is a vigorous perennial, attaining a height of 5 to 8 feet, and is absolutely hardy throughout the United States and Canada.

The Mountain Feather Fleece is of easy cultivation, but takes some time to become well established, and, if given plenty of food, makes a wonderful show equaled by few plants of any description. It prefers a moist and partially shaded position. It would be impossible to give an idea of the wonderful effect of a large mass of Stenanthiums when in full bloom, as no description conveys the beauty of the delicate, feathered, drooping flowers. Strong plants, 50 cts. each, $\$ 5$ per doz.

\section{Viburnum tomentosum}

We think this one of the most beautiful and satisfactory shrubs in cultivation. Closely allied to the Japanese Snowball, but much hardier-in fact, perfectly hardy. More vigorous in growth and much handsomer foliage, which turns a beautiful wine-red in the fall. Either for planting in masses or as specimens, it cannot be surpassed. As a specimen it makes a perfectshaped bush 10 feet high and as many feet across. Its beautiful white flowers are produced in May. Strong plants, 30 cts each, \$3 per doz., \$20 per 100 . 


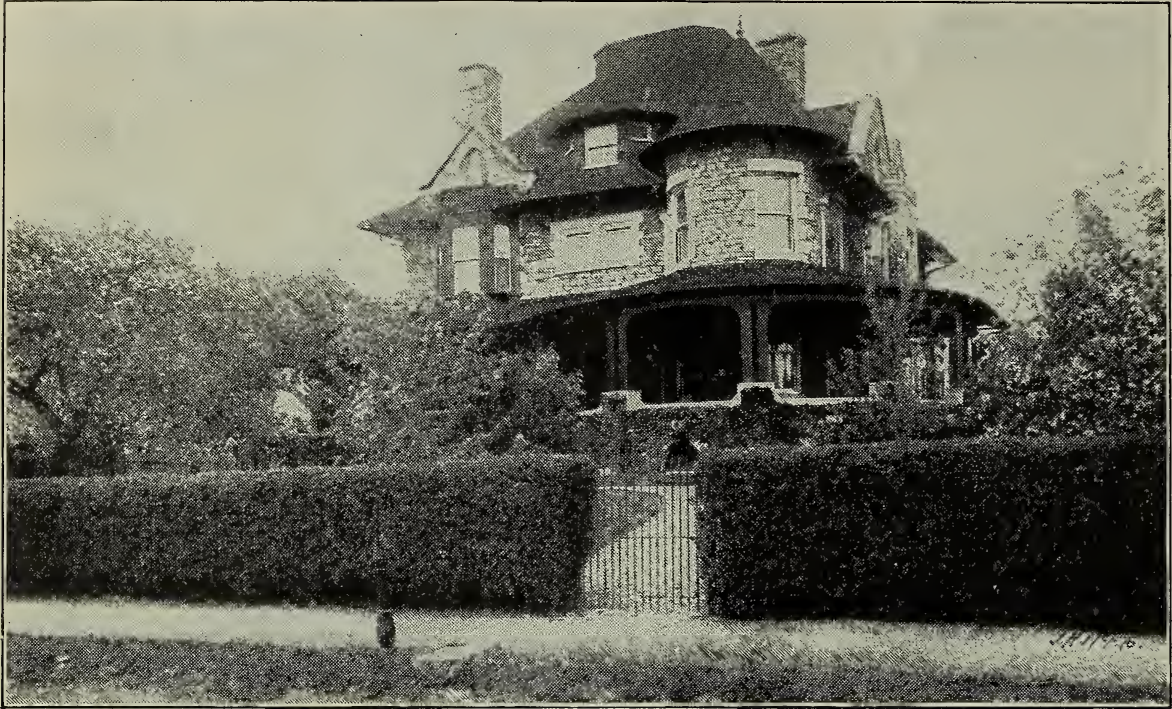

Ligustrum Amurense

\section{Ligustrum} Amurense

(AMOOR PRIVET;

A more slender grower than the conmon Privet. Hardier than the California, while the foliage is finer and of a lighter green, and retains a better color during the winter. It makes a more satisfactory hedge than the California, and should be more extensively planted. We offer the true variety. The Privet generally sold in the South for Amoor River is Ligustrum Chinense, and is not hardy in the North. While we are reading proof of this Catalogue the temperature is about 20 degrees below zero over a wide range of country, which means that California privet will be again killed to the ground. $15 \mathrm{cts}$. each, $\$ 1.50$ per doz., $\$ 8$ per 100 .

\section{New Rose Killarney}

Probably no Rose has ever taken such a prominent place so quickly as Killarney. It is already one of the most popular of our Garden Roses, and also one of the leading varieties for winter cut-flowers. It is perfectly hardy in this latitude; in growth it is strong and robust, and as free-flowering as any Rose we know. In color it is a sparkling, brilliant imperial pink; the blooms are large, the buds long and pointed; the petals very large, and of great substance, and just as handsome in the full-blown flower as in the bud form. 30 cts. each, \$3 per doz. Potgrown plants ready in May, 20 cts. each, $\$ 2.25$ per doz., $\$ 16$ per 100 .

\section{Phlox divaricata Laphami}

Variety of $P$. Canadensis, one of the finest hardy perennials adapted for the rockery, for the border and for naturalizing; remarkably free-blooming; forms a somewhat shrubby plant 18 inches in height. Individual flowers much larger than P. Canadensis; the heads are larger, and the petals not cleft as in the type. One of the really good new things which we have thoroughly tested. 25c. ea., $\$ 2.50$ per doz.

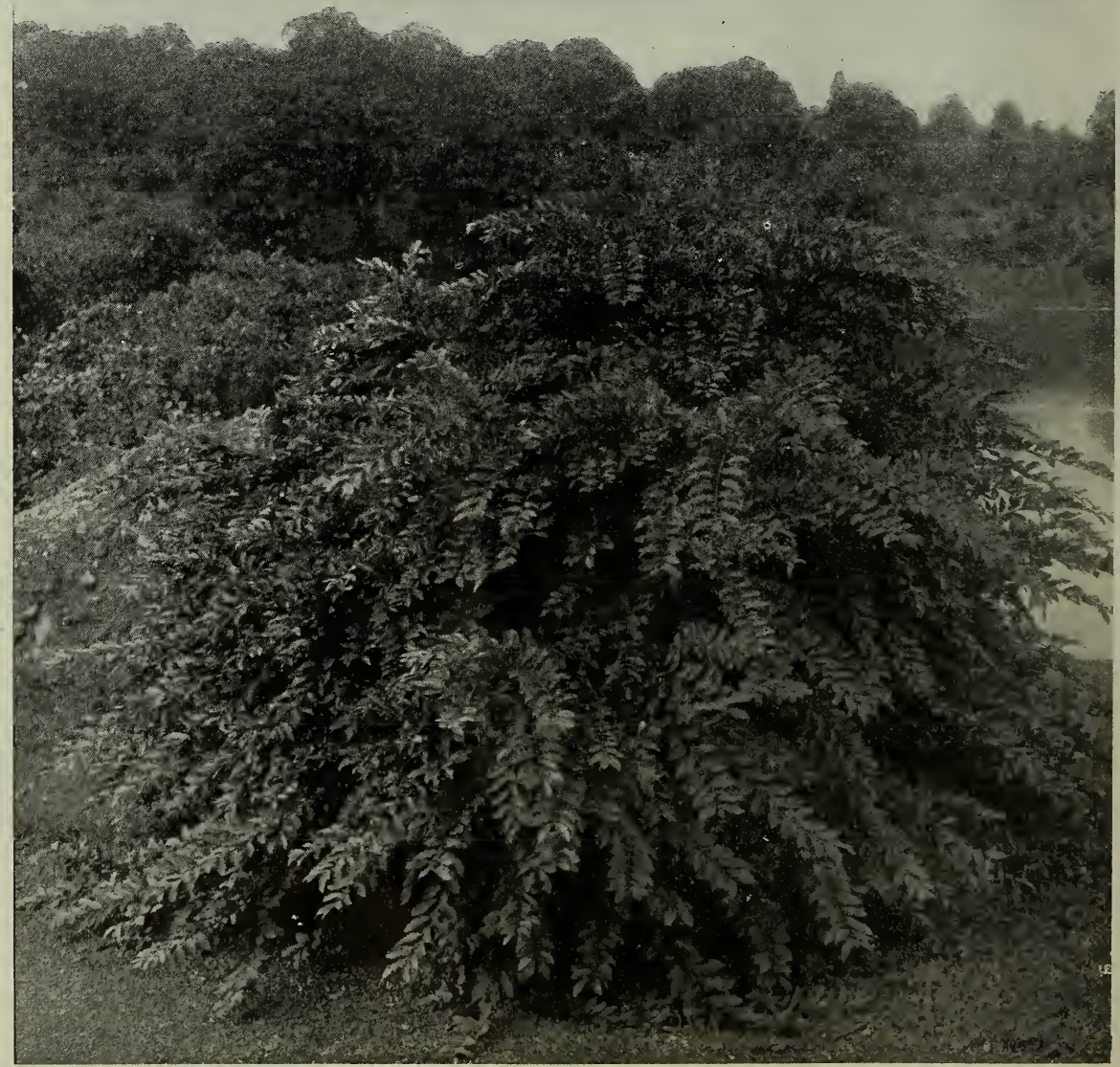

Regel's Privet (See page 10) 


\section{New Rugosa Rose, "Blanche Double de Coubert"}

The very desirable qualities of the Rugosa Roses have led the hybridizers to attempt the production of new varieties, and many Rugosa Hybrids have been offered, but with a single exception they are like the play of Hamlet with Hamlet left out. New colors and forms of flowers have beell produced but the vigor and all the desirable qualities of the Rugosa parent have been lost. The exception is the Rose named above, which is identical with the Rugosa species in foliage, habit and vigor, but has semi-double pure white flowers which are most deliciously fragrant. The llowers are produced freely throughout the season. On our grounds it is the first Rose in bloom in spring and the last in the fall. We have known for some years that this was a most valuable Rose but the stock was so scarce that we didn't dare say much about it. Valuable for grouping or planting in the shrubbery, and makes a most attractive untrimmed hedge. 35 cts. each, $\$ 3.50$ per doz., $\$ 25$ per 100 .

\section{Sciadopitys verticillata}

This rare Japanese evergreen is one of the most distinct and beautiful varieties in cultivation. It is not perfectly hardy north of this, but can be grown in a sheltered position. We have a stock of extremely fine plants coming from Japan. 2 to $3 \mathrm{ft} ., \$ 2.25 ; 3$ to $4 \mathrm{ft} ., \$ 6.50 ; 5$ to $6 \mathrm{ft} ., 58,50$.

\section{Symphoricarpos}

There is no more useful or desirable shrub than this. It is of the easiest culture, thriving in full sun, and it will stand more shade than any other shrub we know. For covering ground under trees there is nothing better. The red-fruited variety, known as Indian Currant, is especially effective in the winter when the ground is covered with snow, and the loveliness of the white-fruited sort, commonly called Snowberry, is shown by the illustration. Price of either variety, 20 cts. each, $\$ 1.75$ per doz., $\$ 13$ per 100 .

\section{Hydrangea scandens}

This is the true climbling Hydrangea, one of the rarest and most difficult vines to obtain We have succeeded in getting a small stock from Japan. It is of slow growth, but a plant will eventually cover the end of a house and is wonderfully beautiful when in bloom. Strong plants 75 cts. each.

\section{"Baby Crimson Rambler"}

This Rose is a cross between Crimson Rambler and Gloire de Polyantha, showing all the qualities of Crimson Rambler and at the same time flowering perpetually as a Polyantha Rose. Madame N. Levavasseur, however, is not a climbing Rose; it does not grow higher than 2 to $2 \frac{1}{2}$ feet, forming a lovely bush, all covered with flowers and blooming from spring until frost. Strong plants, 25 cts. each, $\$ 2.50$ per doz, $\$ 18$ per 100 .

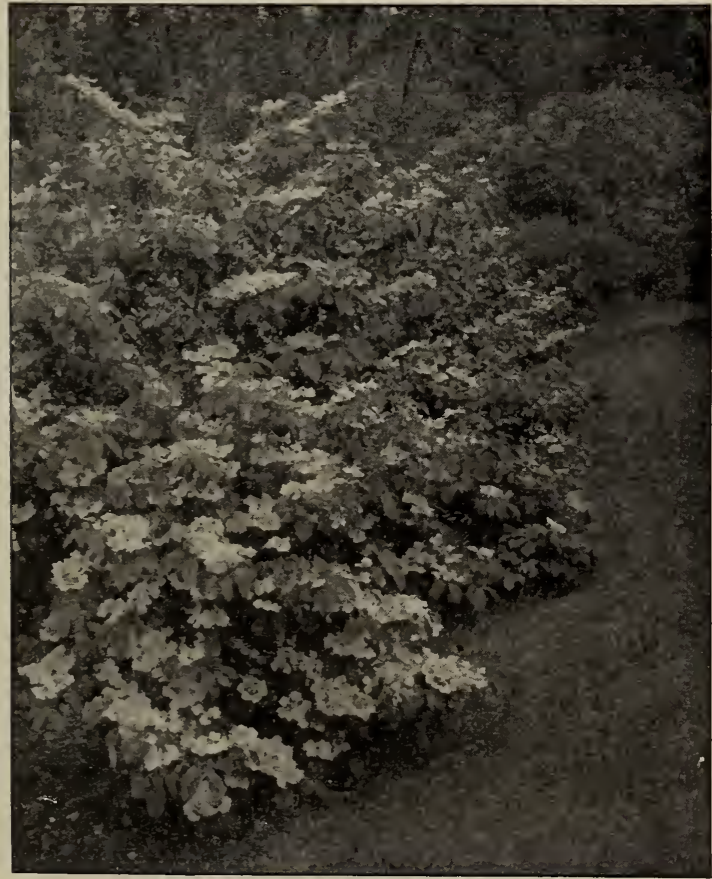

Viburnum tomentosum (see page 5)

\section{Spiræa Filapendula}

A plant of decided merit growing 2 to $2 \frac{1}{2}$ feet high, with fern-like foliage, with loose clusters of white flowers; blooms end of May. $15 \mathrm{cts}$. each, $\$ 1.50$ per doz.

\section{Hardy Bamboos}

The following Bamboos have proven perfectly hardy in the latitude of Philadelphia.

BAMBUSA AUREA has straight, erect, slender stems, with very short internodes, which have attained heights of 12 to 15 feet in this country. It is one of the most graceful of the genus and particularly effective when planted in large, bold masses. \$1 each; large plants, \$2.

BAMBUSA JAPONICA (Metake of gardens). One of the best known of all the hardy Bamboos. The stems are often 15 feet high, with internodes 6 to 8 inches long, and with tapering leaves a foot long, smooth and shining above, glaucous beneath. It forms fine clumps when sheltered from the east wind, and will grow in drier situations than most Bamboos. $50 \mathrm{cts}$. each; large plants, $\$ 1$.

\section{Anemone Pennsylvanica}

This fine native wild flower would sell by the thousands if it were well known, for it is really one of the most desirable of hardy plants and especially so when naturalized in large masses. It is of the easiest culture, requiring no attention after planting, and increases with great rapidity, so that a large space of ground can soon be covered with it. It grows about 12 inches high, has good foliage throughout the season, and in June is covered with charming white single flowers. 15 cts. each, $\$ 1.50$ per doz., $\$ 10$ per 100 .

\section{Lily-of-the-Valley}

We can supply good strong pips of the American Lily-of-the-Valley at 20 cts. per doz., $\$ 1.25$ per 100 . They should be planted 3 or 4 inches apart in a artially shaded position. 


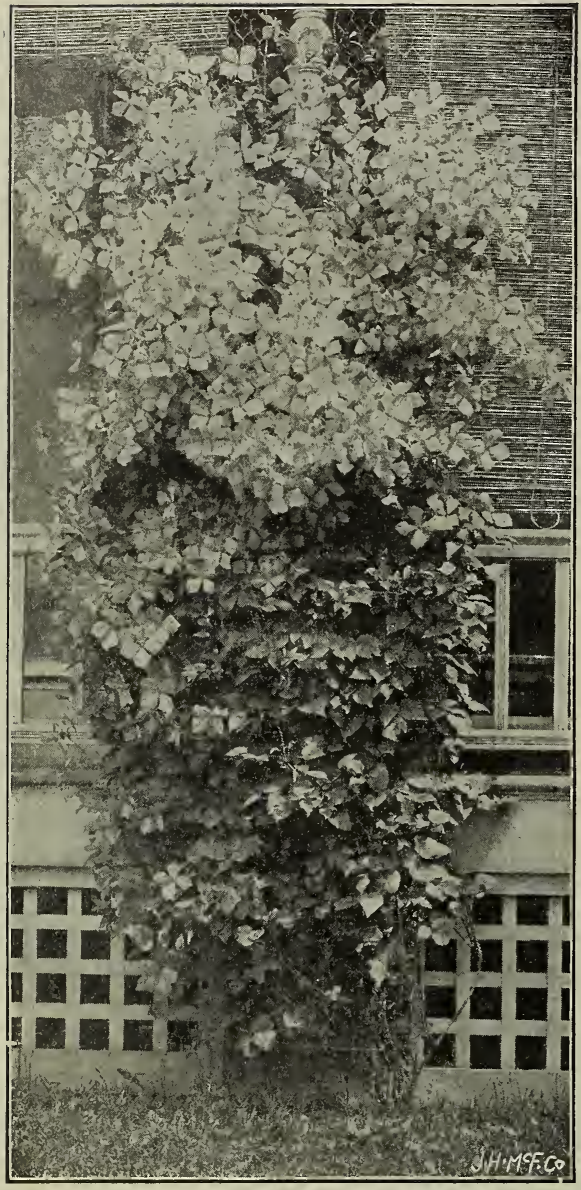

Large-flowering Clematis

\section{New Weeping Colorado Blue Spruce}

\section{(Picea pungens glauca pendula)}

This splendid new evergreen is undoubtedly one of the finest novelties ever sent out, and was awarded First-class Certificates by the Royal Horticultural Society, London, and the Pomological Society of Holland. This variety has fine rich blue foliage, even brighter than the upright-growing variety, and possesses all the desirable and valuable qualities of its parents. The great quality of this new conifer is its striking and graceful pendulous habit in all stages of its growth. All the branches, even the young shoots, are very drooping

This evergreen is recommended to those who desire a tree of great distinction and rarity. $2 \frac{1}{2}$ to 3 feet, $\$ 4$ each; 4 feet, $\$ 8$ each.

\section{Japanese Cherries}

The double-flowering Japanese Cherries are beautiful beyond description, and nothing is more free-flowering-even the smallest are covered with the lovely white or delicate pink flowers early in the spring, before the leaves appear. $75 \mathrm{c}$. ea., $\$ 8$ per doz.

\section{CLEMATIS}

COCCINEA HYBRIDS. These are a new race of hardy Clematis, obtained by Messrs. George Jackman \& Son from the beautiful American species, $C$. coccinea, and one of the older hybrids, named Star of India. The flowers of the progeny are quite distinct, both in color and shape, from all other Clematis in cultivation, and the plants are hardy, free-growing and free-flowering

COUNTESS OF ONSLOW. Flowers bell-shaped, bright violet-purple, with a broad scarlet median band on each petal. First-class certificate, Royal Horticultural Society. Extra strong plants, $\$ 1$.

DUCHESS OF ALBANY. Flowers bright pink, deeper in the center, lighter at the edge of the petals. Useful for cutting. Award of Merit, Royal Horticultural Society. Extra-strong plants, $\$ 1$.

\section{LARGE-FLOWERED CLEMATIS}

We have secured a limited stock of extra-large and strong plants of the following: 75 cts. each, $\$ 8$ per doz., except where noted

Jackmani. The well-known purple variety.

Fairy Queen. White, lilac burs.

Gypsy Queen. Dark purple.

Henryi. Pure white; extra large.

M. Koster. Bright rosy carmine; very free-flowering variety.

Ville de Lyon. Fine new variety; brilliant carmine-red, strong grower; $\$ 1$ ea.

sieboldii. Lavender-blue.

\section{Climbing Hydrangea}

We have at last succeeded in getting a stock of the rare Schizophragma Hydrangeoides, known as the Climbing Hydrangea. It is one of the rarest and most beautiful vines, having flowers similar to Hydrangea Hortensia. Fine, strong, pot-grown plants, 50 cts. each, $\$ 5$ per doz.

\section{New Upright Honeysuckles}

We have never seen anything more striking than the display of the New Upright Honeysuckles in the Arnold Arboretum in Boston. These splendid shrubs are made a special feature in this famous botanical garden, and nothing is more worthy of a prominent position. They delight thousands in the spring when they are covered with their charming sweet-scented flowers, but their great glory is at midsummer when they are loaded with the most brilliant and beautiful berries borne by any shrub. When they become known, we predict a popularity for these shrubs beyond that of the popular Hardy Hydrangea which is now sold by the hundreds of thousands. They have a every good quality: Perfect hardiness, vigorous growth, beautiful rich green foliage that is as persistent as that of the California privet and this season was bright and green until almost Christmas, having two distinct seasons of unsurpassed beauty. These must not be confused with the climbing Honeysuckles so extensively used for covering porches. They are vigorous, upright-growing shrubs, suitable for large groups, specimens, screens or untrimmed hedges.

Lonicera bella candida. White. 25 cts. each, \$2.50 per doz., \$16 per 100.

\section{Iris Pallida Folia Variegata}

This new Iris is conspicuous on account of its beautifully variegated foliage, which is of a glaucous green, with broad bands of ereamy yellow, every leaf being well marked. It is of free growth, and when well established attains a height of 2 to $2 \frac{1}{2}$ feet, and is very attractive. Its flowers are of a soft, pale lavender. $50 \mathrm{cts}$. each, $\$ 5$ per doz.

\section{Speaking of Shrubs}

Miss Jekyl, in her book, Wood and Garden, says: "What a precious thing this fine old Mahonia is! What should we do in winter without its vigorous masses of grand foliage in garden and shrubbery, to say nothing of its use indoors? . . When one reflects that Mahonio aquifolium is individually one of the handsomest of small shrubs, that it is at its very best in midwinter, that every leaf is a marvel of beautiful drawing and construction, and that its ruddy winter coloring is a joy to see; and further, when one remembers that in the spring the whole picture changes - that the polished leaves are green again and the bushes are full of tufted masses of brilliant yellow bloom and fuller of bee-music than any other plant then in flower. . . . It is the only hardy shrub I can think of that is in one or other of its varied forms of beauty throughout the year.

\section{Aquilegia Canadensis nana}

A diminutive form of our lovely native Co!umbine, A. Canadensis, with exquisite red flowers. A charming plant for the border or for naturalizing. 15 cts. each, $\$ 1.50$ per doz., $\$ 9$ per 100 . 


\section{Evergreens Specially Prepared for Transplanting}

The following Evergreens have all been specially prepared for transplanting by shearing and frequent transplanting, and will be shipped with ball of earth about their roots. They are from leading European and American nurseries, and if wanted in quantity must be ordered before March 1. Such evergreens are much higher priced than those grown and handled in the ordinary way, but really they are cheaper and give much greater satisfactionn, for, if planted with any care whatever, every tree will grow.

ABIES concolor violacea (Concolor Spruce). 4 feet........ Each

3 feet...................................... 400

Nordmanniana (Nordmann's Fir). The Nordmann's Fir is one of the handsomest evergreens, and is unsurpassed in form and

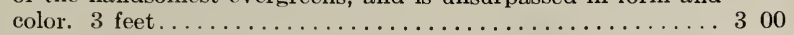

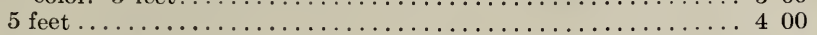

brachyphylla. Distinct and hardy; fine green foliage. 3 to 4 feet.. 200 Cilicica. A beautiful rare tree with fine dark green leaves that are silvery white beneath. 4 feet ................. 200

firma. An erect tree of great beauty and hardiness. 5 feet..... 400

CR YPTOMERIA Lobbi. An evergreen of great distinction and beauty, and the only variety of the species hardy in this climate.

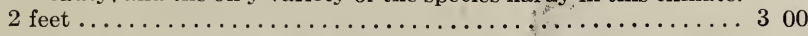

JUNIPERUS Canadensis aurea. A dwarf Juniper of great beauty and hardiness. Extra-fine specimens, 18 inches high...... 125

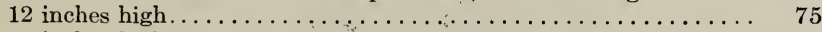

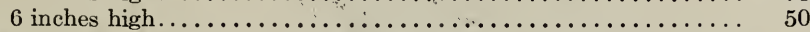

Japonica aurea. Very beautiful Japanese Juniper, with splendid golden color. 3 to 4 feet....................... 300

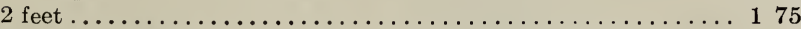

Sinensis Pfitzeriana. An elegant tree with fine feathery foliage, light silvery green in color; absolutely hardy. 3 to 4 feet..... 400

procumbens. (Creeping Juniper.) Small plants............ 25

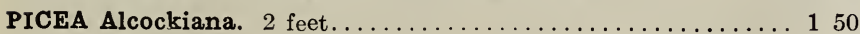

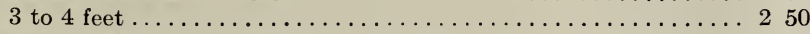

excelsa inverta (Weeping Norway Spruce) ............. 150

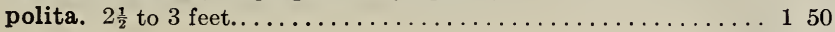

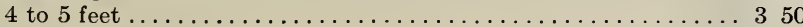

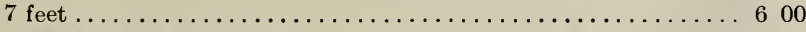

pungens glauca (Koster's Blue Spruce). The Koster Blue Spruce

is the bluest of all blue Spruces. $2 \frac{1}{2}$ feet..............6 600

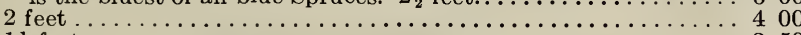

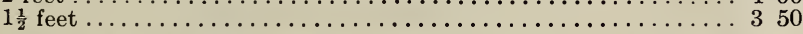

TAXUS Canadensis Washingtoni. A fine dwarf Yew with varie-

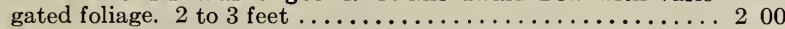

cuspidata brevifolia. A fine form of the Japanese Yew, and perfectly hardy. 2 feet............................. 200

TSUGA Canadensis (Hemlock Spruce). Sheared and bushy. 3 feet. 150

$3 \frac{1}{2}$ to 4 feet ................................. 400

Canadensis Fremdi. A splendid variety of Hemlock, with thick, glossy foliage and forming a perfect-shaped tree. $3 \frac{1}{2}$ feet... 300

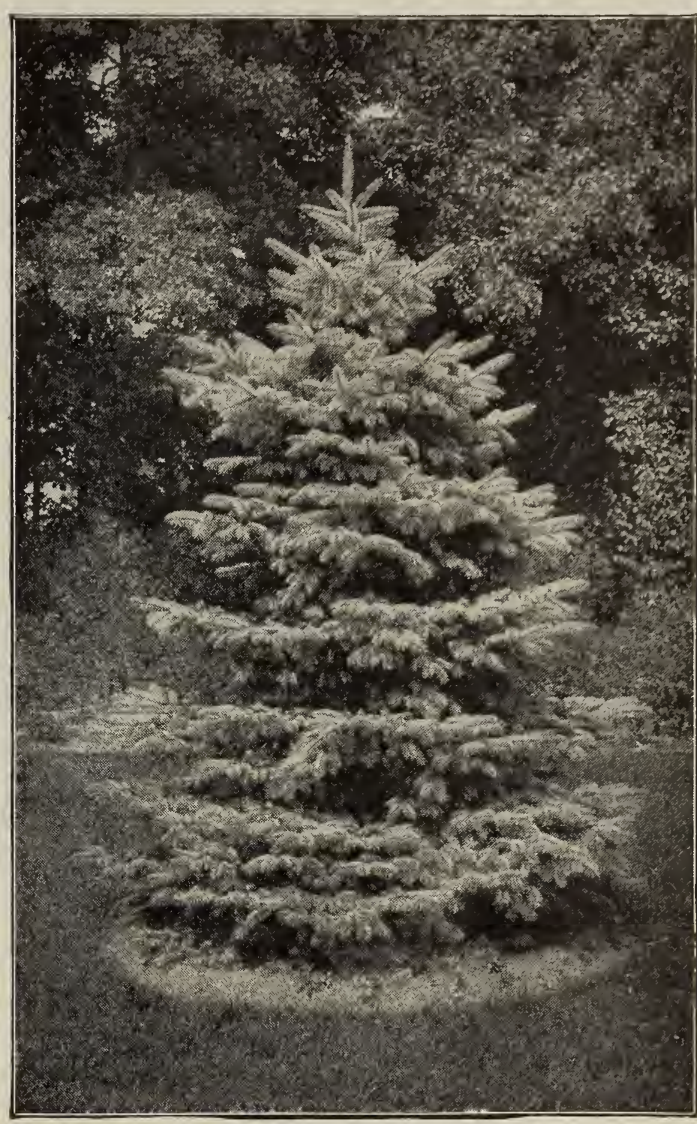

Koster's Blue Spruce

\section{A Bargain in Extra-Large Shrubs}

We have a lot of extra-large shrubs on ground that we wish to clear. These shrubs range from 3 feet to 6 feet high, and are extra strong and bushy; such shrubs as are sold by many nurseries at 50 cents to $\$ 1$ each, but to close them out quickly we offer them at $\$ 13$ per 100 , but packing will be charged for in addition at cost. In a carload lot we will pack them free. The varieties are as follows: Cornus Sibirica, C. sanguinea, C. stolonifera, C. sericea, Spiraea opulifolia aurea, S. Billardii, S. Douglasii, S. Regeliana. S. carpinifolia, Philadelphus grandiflorus, P. Sutzmannii, Symphoricarpos racemosus. 


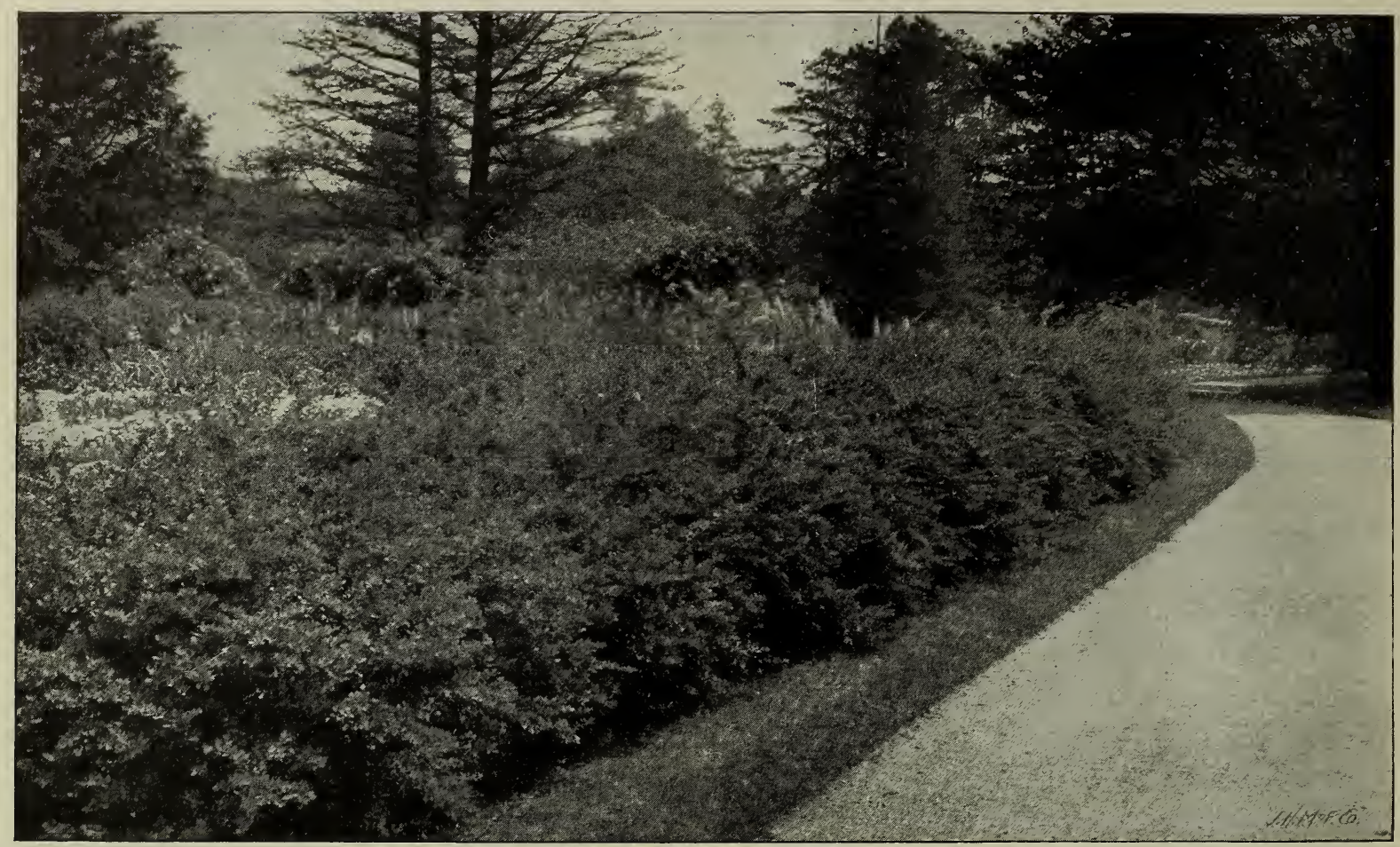

Japanese Barberry Hedge

\section{The Best Hedges}

\section{Japanese Barberry}

We are frequently asked to recommend the best shrub for hedge planting, and, after many years' experience, we are decidedly of the opinion that the Japanese Barberry, Berberis Thunbergi, is the best hedge plant in existence, and either as an ornamental, defensive, trimmed or untrimmed hedge, it is unsurpassed. As an ornamental hedge it is beautiful throughout the year, its abundant crop of bright red berries makes it even more attractive in the winter than the summer. Its compact growth and thorny branches make a defensive hedge that will turn cattle after five years' growth. As an untrimmed hedge, it requires no attention except an occasional cutting of a few straggling branches. The natural growth is so dense and even that it forms a perfect hedge without shearing, but if a formal hedge is desired, by shearing, it can be made as even as a stone wall. This Berberis is absolutely hardy, of the easiest culture, and will grow in any soil or situation. It will stand considerable shade and can be grown under trees if not planted too closely to the trunks. It is of slow, compact growth, but will eventually attain a height of 5 or 6 feet. It is also one of the very best of shrubs for general planting. For a hedge, plant a single row 18 inches apart in the row. We have a very large stock of fine plants which we offer at $\$ 8, \$ 10, \$ 13, \$ 16$ and $\$ 20$ per 100 , according to size. Special prices quoted on lots of one to ten thousand, on application.

\section{Actinidia arguta}

This vine is little known, but is really one of the best, and we highly commend it for either porch, trellis or pergola. Vigorous grower of distinguished effect. Leaves bright green with red stems; very clean in appearance and not subject to attack of insects or disease. Strong pot-grown plants, 50 cts. each, $\$ 5$ per doz.

\section{Regel's Privet}

Regel's Privet is not only the best Privet, but is also one of the very best shrubs for many purposes that we know of. Is perfectly hardy, of most beautiful pendulous habit and splendid foliage. It is of vigorous growth and will thrive in either sun or shade. In good soil it will attain a height of 8 or 10 feet, and spread almost as great. It is fine as a specimen or for planting in masses in the shrubbery, but its greatest value is for hedging. As a hedge plant it is unsurpassed. It can be kept closely trimmed, or trimmed but little, when it will preserve its natural drooping character which is most graceful and beautiful. A partially trimmed hedge of this Privet on the grounds of $\mathbf{M r}$. Clarence Byrnes, Sewickly, Pa., we think one of the handsomest hedges we have ever seen. On account of its spreading habit this Privet makes a hedge solid to the ground whether it is sheared hard or not. We can not understand why people continue to plant California Privet, which is inferior in every respect and not reliably hardy. Regel's Privet is somewhat higher-priced, but on account of its spreading habit it requires only half the quantity that it does of the California Privet to plant a hedge. For a hedge, plant Regel's Privet 18 inches apart in a single row. We offer a splendid stock at the following prices: $2 \frac{1}{2}$ to 3 feet, 20 cts. each, $\$ 2$ per doz., $\$ 15$ per $100 ; 12$ to 18 inches, 15 cts. each, $\$ 1.50$ per doz., $\$ 10$ per 100 . (See illustration on page 6 .)

\section{Incarvillea delavayi (Hardy Gloxinia)}

A new, hardy tuberous-rooted plant, and one of the choicest perennial plants introduced in recent years. It produces large, gloxinia-like rose-colored flowers, which last in perfection a long time; these are produced in clusters on stems 18 inches high; should be protected with a covering of leaves during winter. 15 cts. each, $\$ 1.50$ per doz. 


\section{Extra-Fine Specimens MAGNOLIA}

STELLATA. Of this exquisitely beautiful dwarf white Magnolia we have secured some fine bushy specimens that have been grown in pots. 3 feet, $\$ 3$ each; from 8-inch pots, $\$ 1.50$.

FINE BUSHY SPECIMENS, specially prepared for transplanting, in the following varieties: Alexandrina, white and red; Norbertiana, white, purple at base of petals; Soulangeana, white, with deep flush of purple; Speciosa, white, blush at base of petals, and Speciosa nova, white. \$3 each.

LENNE. Reddish purple. $\$ 4$ each.

CONSPICUA (Yulan). Pure white. \$5 each.

The Chinese Magnolias are the most beautiful of all spring flowering trees, but as ordinarily grown in American nurseries, almost impossible to transplant successfully. The above, imported from Europe, have been specially prepared for transplanting and are certain to grow.

\section{Wistaria Sinensis}

We have a few extra-large plants of the well-known purple Chinese Wistaria, with extra-heavy tops. 50c. and $75 \mathrm{cts}$. each, according to size.

\section{ROSES}

STANDARD CRIMSON RAMBLER. This Rose, on account of its free-flowering qualities and vigorous growth, makes a beautiful object when grown as a standard. Fine strong plants, $\$ 1$ each.

CRIMSON RAMBLER. A few extra-strong plants, 50 cts. each, $\$ 5$ per doz.
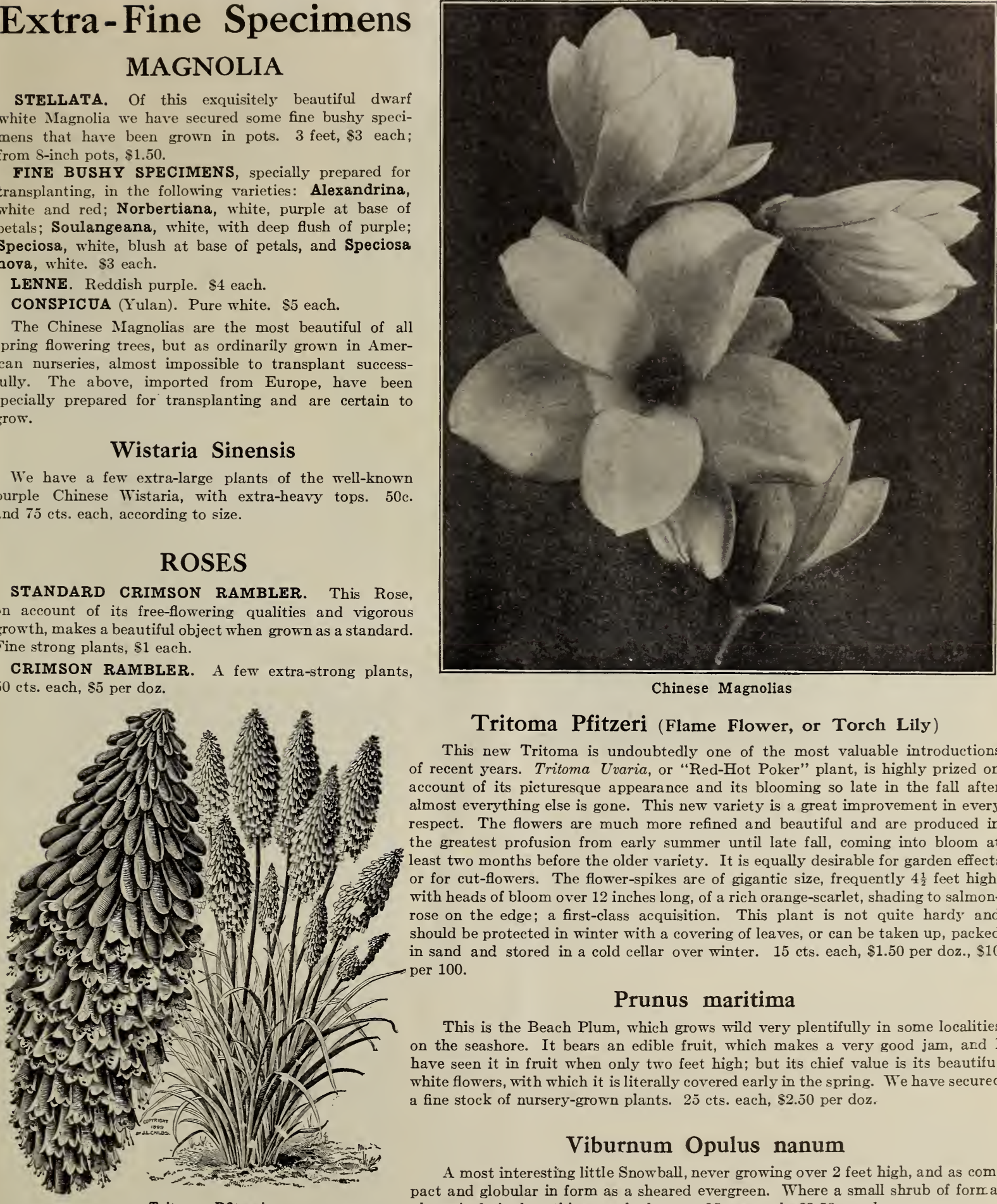

Chinese Magnolias

\section{Tritoma Pfitzeri (Flame Flower, or Torch Lily)}

This new Tritoma is undoubtedly one of the most valuable introductions of recent years. Tritoma Uvaria, or "Red-Hot Poker" plant, is highly prized on account of its picturesque appearance and its blooming so late in the fall after almost everything else is gone. This new variety is a great improvement in every respect. The flowers are much more refined and beautiful and are produced in the greatest profusion from early summer until late fall, coming into bloom at least two months before the older variety. It is equally desirable for garden effects or for cut-flowers. The flower-spikes are of gigantic size, frequently $4 \frac{1}{2}$ feet high, with heads of bloom over 12 inches long, of a rich orange-scarlet, shading to salmonrose on the edge; a first-class acquisition. This plant is not quite hardy and should be protected in winter with a covering of leaves, or can be taken up, packed in sand and stored in a cold cellar over winter. $15 \mathrm{cts}$. each, $\$ 1.50$ per doz., $\$ 10$ per 100.

\section{Prunus maritima}

This is the Beach Plum, which grows wild very plentifully in some localities on the seashore. It bears an edible fruit, which makes a very good jam, and I have seen it in fruit when only two feet high; but its chief value is its beautiful white flowers, with which it is literally covered early in the spring. We have secured a fine stock of nursery-grown plants. 25 cts. each, $\$ 2.50$ per doz.

\section{Viburnum Opulus nanum}

A most interesting little Snowball, never growing over 2 feet high, and as compact and globular in form as a sheared evergreen. Where a small shrub of formal shape is desired, nothing can be better. 35 cts. each, $\$ 3.50$ per doz.

The Blue Rose Is it blue? Possibly, but it belongs to that class of blues that one gets after a night of dissipation. We The Blue Rose. Is it have it, but are not selling it. 


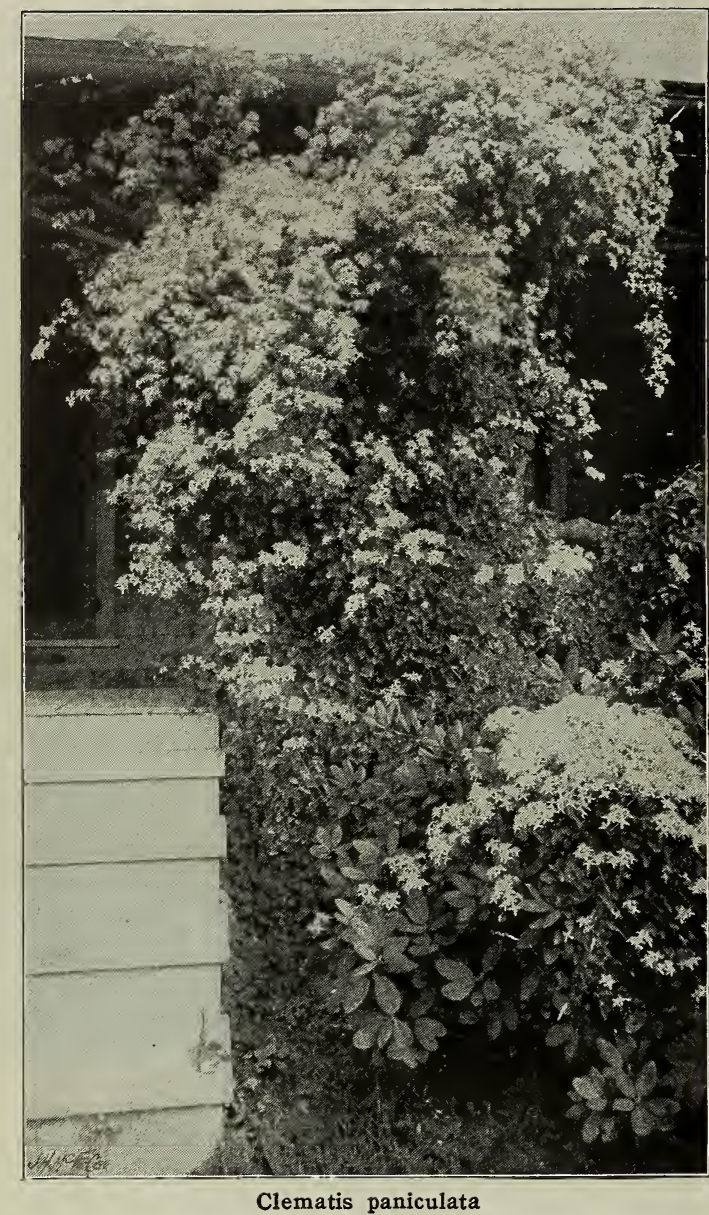

\section{Clematis paniculata}

This handsome hardy climber is one of the choicest and most satisfactory climbling flowering plants we know. The plant is of strong, rapid growth, with small, dense, cheerful green foliage, giving it a grace and elegance possessed by no other hardy climber, and, even did it not flower at all, it would be one of the most desirable vines. The flowers appear in the greatest profusion during August and continue until late in the fall, are of white color and most deliciously fragrant. The plant succeeds in almost any position; not only is it well adapted to run up all kinds of supports, but it is just as useful for planting among rockwork, sloping banks, or, in fact, any position where a graceful vine is desired.

$$
\begin{aligned}
& \text { 2-year-old. } \\
& 3 \text {-year-old, extra strong } \\
& \text { 4-year-old, extra strong }
\end{aligned}
$$

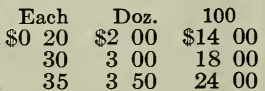

\section{HEMEROCALLIS (Yellow Day Lily)}

The varieties here offered are immense improvements on the wellknown Yellow Day Lily, and should be found in every border of hardy plants.

Aurantiaca. Exceedingly large trumpet-shaped, bright orange-yellow, sweet-scented flowers during June and July. $25 \mathrm{cts}$. each.

Aurantiaca major. Very free-flowering, with trumpet-shaped, sweet-scented deep orange flowers, which, on well-established plants measure 5 inches across. July and August. 25 cts. each.

Florham. Produces very large golden yellow, sweet-scented flowers during June and July. This variety is of American origin, and we believe is the best of all Hemerocallis in commerce. 25 cts. each.

\section{Stuartia pentagyna}

This is not a novelty, but an extremely scarce, rare and beautiful shrub belonging to the Camellia family and resembling a single Camellia in flower. The flowers are creamy white with crimson-red stamens, about 3 inches across. Very hardy and exquisitely beautiful. $\$ 1$ each, $\$ 10$ per doz.

\section{Salix Salamoni}

This is a new variety of Weeping Willow, of remarkably rapid growth. A tree of it on my grounds, four years old from a cutting, is 20 feet high. It is not as pendulous as the old Weeping Willow, but is much handsomer. $75 \mathrm{cts}$. each.

\section{Cornus stolonifera pendula}

This is a new variety of dwarf Dogwood originating in our nursery, which is very valuable for planting on the banks of streams or ponds, or on steep banks. It is a compact, low-growing shrub with pendulous branches. As it spreads from the roots it soon covers a large area closely. It is of the easiest culture and will thrive in almost any soil or situation. 20 cts. each, \$2 per doz., \$14 per 100

\section{POLYGONUM}

BALDSCHUANICUM. A hardy climber of recent introduction from the mountains of Turkestan; it is of rapid growth, frequently attaining a height of 10 to 12 feet in one season. The stems are twining and cling for support to any object within reach. Every branchlet terminates in a panicle of white, foamy flowers, which are produced during August and September. Strong plants, $75 \mathrm{cts}$. each.

MULTIFLORUM. Another grand addition to our list of rapidgrowing hardy climbers, attaining a height of 15 to 20 feet in a single season, and one which seems peculiarly adapted to our climatic conditions. It has bright green heart-shaped foliage, which does not appear to be attacked by any insect pest, and during September and October produces masses of delicate white flowers in trusses at the axils of every leaf. Erroneously this plant has been distributed by some growers as $P$. Baldschuanicum, from which it is quite distinct. Good young plants, $25 \mathrm{cts}$. each, $\$ 2.50$ per doz.

\section{CLEMATIS}

Integrifolia Durandi. A deep steel-blue, large-flowering Clematis non-climbing, growing from 4 to 5 feet, flowering from June till October. Not subject to the Clematis disease. Nice plants, 75c. ea. Montana Grandiflora. A large-flowering variety of the useful and well-known Clematis montana; perfectly hardy. \$1 each.

Montana rubens. A Montana variety with soft rosy red flowers, very useful and attractive; perfectly hardy. $\$ 1.50$ each.

Tangutica. The flowers are of a rich golden yellow, solitary, produced on peduncles 6 inches long. Foliage coarsely serrate and of a glaucous green hue; perfectly hardy. Strong plants, $\$ 2$ each.

\section{WATER LILIES}

N YMPH

Gladstoniana. White. Strong grower......... $50 \quad 500$

Marliacea chromatella. Best yellow.......... $75 \quad 750$

Marliacea rosea. Best pink................. $100 \quad 1000$

Odorata. Common Pond Lily.............. $20 \quad 200$

Tuberosa rosea. Exquisite shade of pink ....... $50 \quad 500$

Tuberosa richardsonni. White flowers........ $50 \quad 500$

Devoniensis. Tender; large red flowers......... $75 \quad 7 \quad 50$

Dentata. Tender; large white flowers.......... $75 \quad 7 \quad 50$

Zanzibariensis. Tender; deep purplish blue..... 150

Zanzibariensis azurea. Tender; blue........ 75

NELUMBIUM album striatum. ........... 300

Album grandiflorum. Best white ......... 250

Luteum. Yellow...................... 125

Pekinensis rubrum. Rosy carmine......... 400

Pekinensis rubrum plenum. Double carmine

flowers.......................... 500

Shiroman. Double white.............. 300

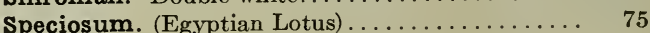

Speciosum. Large plants............... 150

The above are the very best of the Water Lilies, and all that are really worth growing. 


\section{SOME GOOD LILIES}

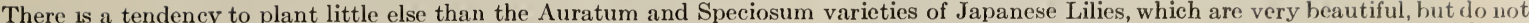

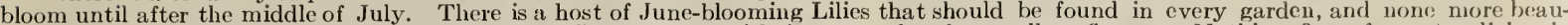

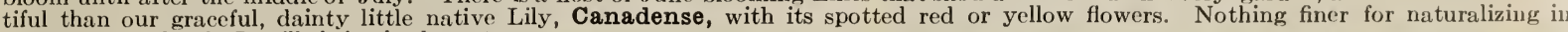
meadow or orchard. It will thrive in the wettést ground, and so will the splendid Superbuns, also a native Lily, blooming the end of June or early in July. We have seen the plants of this 8 feet high, with 30 or 40 flowers. All varieties of Thunbergianum (Elegans) and Umbellatum Lilies bloom in June, and none are more vigorous and hardy or showier when planted in large clumps, and they are abundantly able to take care of themselves in almost any situation; and so are all varieties of Tiger Lilies, which make bold and most effective groups. A Japanese Lily, not so well known, is Hansoni, but one of the most distinct and desirable. It has a trick, however, of remaining dormant for a year after it is planted; in fact, I think it always does this if planted in the spring. Henryi, the new variety from Japan, is wonderfully vigorous and fine when established, but, as yet, the bulbs are extremely scarce and difficult to get. Brownii and Excelsum are two lovely Lilies, but the bulbs are getting very scarce and high-priced.

\section{Lilies for Spring Planting}

The Lily bulbs otfered below were received from Japan in December, were repacked in sand and stored in a cold cellar, and are now in prime condition for spring planting.

Lilies like a light, rich, well-drained but moist soil, and a partially shaded location. If planted in full exposure to the sun, the bed

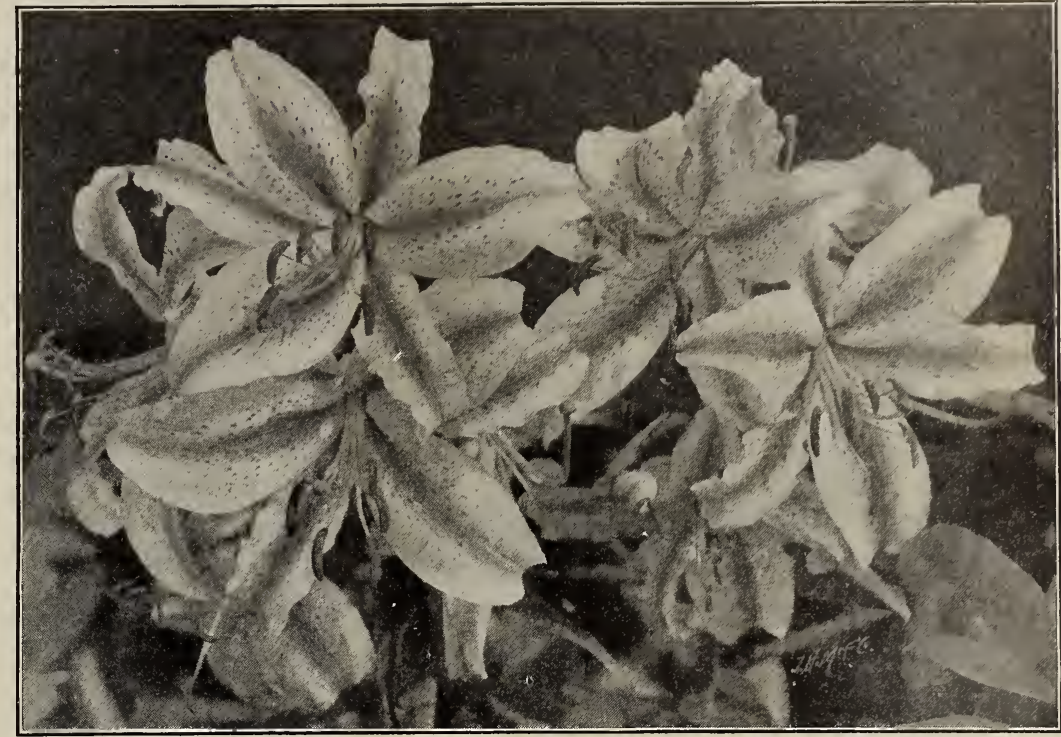

Lilium auratum

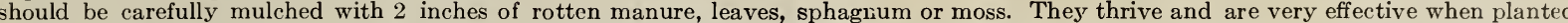

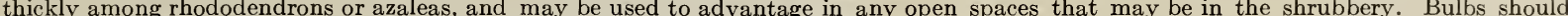

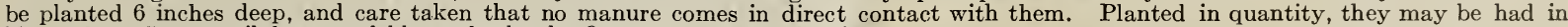
bloom from June until frost, and bloom freely the first season after planting.

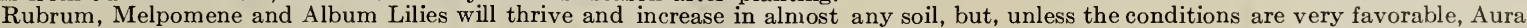
tum Lilies deteriorate and a percentage will be lost every year; but they are so truly splendid, and are so inexpensive at the low prices at which we offer them,

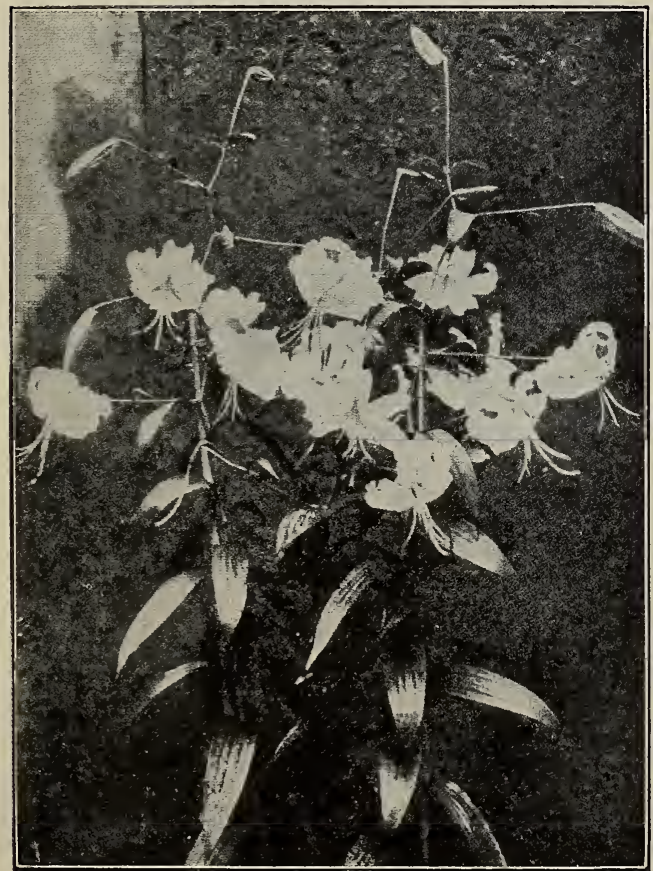

Lilium speciosum album that they will be found the best garden investment that can be made. Try these Lilies, and send your order at once, so that they can be sent to you early in the spring. Longiflorums are similar in appearance to the Bermuda Easter Lilies, but are much more satisfactory for outdoor planting, as they are perfectly hardy.

\section{PRICES OF LILIES}

The measurements given refer to circumference of bulbs, but the Japanese evidently use an elastic tape, as the bulbs never quite come up to the measurements given. We give these sizes, as they are generally used by the trade.

Auratum. 9 to 11 inches. Per doz. 100

Longiflorum. Ready in October. Has large, pure white, trumpetshaped flowers like the Bermuda Easter Lily, but is quite hardy

5 to 7 inches.

6 to 8 inches.

8 to 10 inches. $\$ 15 \$ 1200$

9 to 11 inches.

11 to 13 inches.

Speciosum Melpomene. Similar to Roseum or Rubrum; more

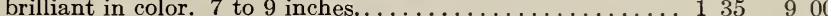

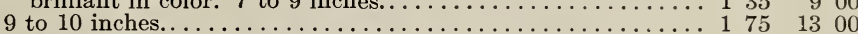

Speciosum rubrum, or roseum. Pink. 8 to 9 inches........ $125 \quad 750$

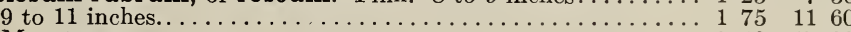

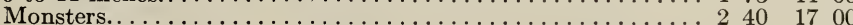

\section{Superbum Lilies}

We make an annual contract to have 25,000 bulbs of this grand Lily grown for us. This enables us to offer it at low prices, which makes it available for naturaliz ing in quantity. It is unquestionably one of the most satisfactory Lilies that can be planted either in the garden or in the meadows, on the edge of woods or in any rough or wild parts of the grounds, where it will take care of itself without any attention whatever after planting. It will also thrive in wet or swampy places It is a grand Lily, often growing over 8 feet high, and produces twenty to thirty beautiful orange-red flowers in July, when flowers are apt to be rather scarce. Extra-selected bulbs, $\$ 1.25$ per doz., $\$ 2.25$ for $25, \$ 7$ for $100, \$ 16.50$ for 250 $\$ 27$ for $500, \$ 50$ per 1,000 . 


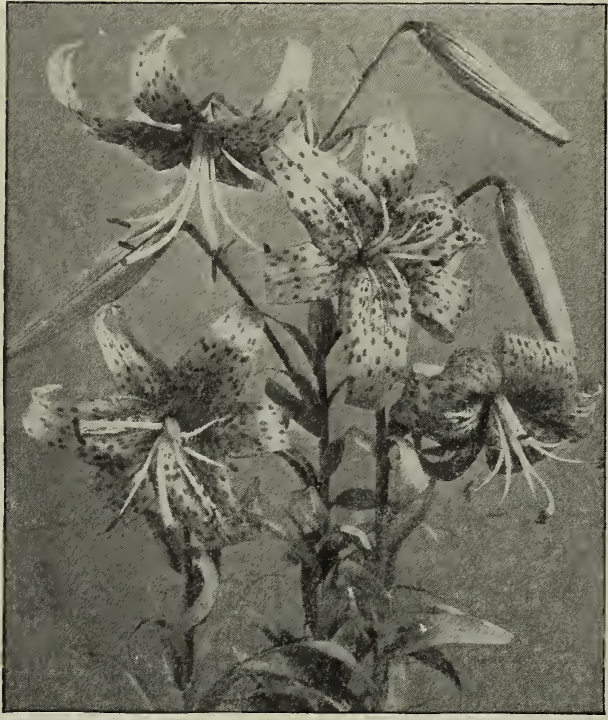

Lilium tigrinum

\section{Other Japanese Lilies}

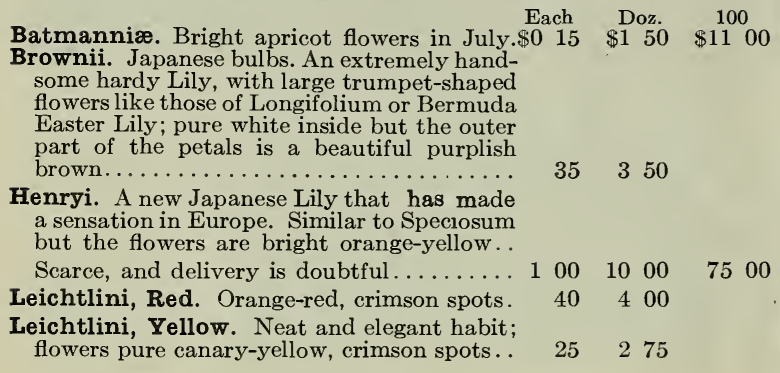

\section{Rubus odoratus}

This is a Flowering Raspberry which grows wild by the tens of thousands in many parts of this country. We want to call special attention to it, for nothing can be better for covering steep and partially shaded banks. It does best on moist north hillsides. It makes masses of most pleasing and effective foliage and its large purplish red flowers are produced all summer. 20 cts. each, $\$ 1.25$ per doz., $\$ 8$ per 100 .

Since the above was written we have tested the shrub in our experimental grounds, and have found it one of the most beautiful shrubs in our collection, and one of the easiest culture. If it never bloomed, its foliage would make it entirely satisfactory. It was planted in full exposure to the sun, in ordinary garden soil.

\section{Sambucus pubens}

This is the Red-berried Elderberry which grows so plentifully in the Adirondacks. It is a vigorous, free-growing shrub, that does equally well in sun or shade. The flowers are inconspicuous; but the fruit, which is most freely produced, is extremely effective, being a brilliant crimson in color, which contrasts splendidly with its fine foliage. It is the first shrub to ripen its fruit, being in full color by the end of May, when the common Elderberry is in bloom. Like most shrubs that thrive in shade it will also do well in full sun. 25 cts. each, $\$ 2.50$ per doz.
OTHER JAPANESE LILIES, continued

Rubellum. This is a beautiful new Lily similar to Each Krameri. It is unknown in this country, but in England, where it has been fully tested, it is highly praised, and it seems likely to become as popular as the Speciosum varieties; subject to Lily disease. $\begin{array}{llll}\$ 0 & 25 & \$ 2 & 25\end{array}$

\section{European-Grown Lilies}

(E)

Yellow; dwarf.\$1 $50 \quad \$ 1000$

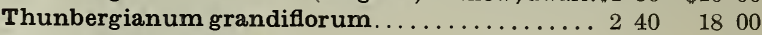

Thunbergianum, Mixed.................. $150 \quad 1000$

Tigrinum flore pleno (The Double Tiger Lily). The only double Tiger Lily worth growing............

Tigrinum simplex (The well-known Single Tiger Lily). Of the easiest culture and worthy of general planting on account of stately habit and fine effect

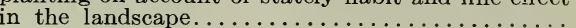

Tigrinum splendens (Improved Single Tiger Lily). . 65

Umbellatum erectum. Scarlet, brown spots...... 150

Umbellatum incomparabile. Dark red, brown spots 180

Umbellatum, Fine Mixture.............. 125

Wallichianum. Immense, white trumpet flowers, suffused with yellow; very scarce..Each, $\$ 2.50$..

\section{Native and American-Grown Lilies}

Canadense flavum. Our dainty, beautiful native Lily. Doz. 100 Graceful and charming yellow flowers.........\$1 $50 \quad \$ 10 \quad 00$

Canadense rubrum. Red flowers............ $150 \quad 1000$

Canadense, Mixed. ................... $75 \quad 5 \quad 50$

Elegans bicolor. Apricot, spotted ............ $175 \quad 1100$

Elegans robusta. Crimson-black; fine......... $175 \quad 1100$

Grayi. A small native Lily. Very dainty and rare.

The bulbs are quite small............... 300

Philadelphicum. Native Lily. Orange-red, black

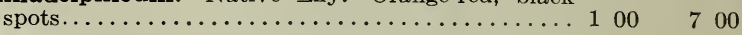

Tenuifolium. A beautiful graceful Lily, with crimson reflex flowers. One of the choicest Lilies, but dies out in a year or two, but can be renewed from seed. Blooms in June...................... 125800

Wallacei. Very free-flowering, hardy, and showy; each bulb sends up many stems which bear several lovely vermilion-orange flowers.................. 125

\section{The Oak-Leaved Hydrangea (Hydrangea quercifolia)}

The Oak-leaved Hydrangea, although a native shrub, is one of the rarest and, in my estimation, one of the most beautiful and picturesque in cultivation. Flowers, foliage, and habit all combine to make it the most striking, and it should be included in every planting list. It is rather dwarf and spreading, and plants over 3 feet high are not often seen. The foliage is distinctly beautiful, the leaves being somewhat of the shape of oak leaves, and slightly white on the under surface. As the plants gain age and strength they assume a picturesque relation to the surroundings that gives them unique value. I have secured a small stock of nice plants, which I do not expect will last half through the season; wherefore, early orders are suggested to avoid disappointment. $50 \mathrm{cts}$. each, $\$ 5$ per doz.

\section{IMPORT PRICE-LIST OF BULBS}

Our Import Price-List of Bulbs is ready the latter part of May, and is mailed to all addresses on our books, and to others on request. We import to order bulbs of exceptional high quality and at a great saving in cost. 


\section{Rhododendron Catawbiense}

All things ronsidered, this is the most desirable Rhododendron in cultivation. It is a native variety, growing wild in the southern mountains. It is absolutely hardy and hardier than any other variety in existence and has the most splendid foliage of all. The flowers range from bright pink to decp reddish purple and are freely produced in Mav. We can not too highly recomnend this Rhododendron as we know it will give unqualified satisfaction. We have a splendid stock of nursery-grown plants which we offer at the following prices, according to size; 1 st size, $\$ 1$ each, $\$ 10$ per doz., $\$ 75$ per $100 ; 2 \mathrm{~d}$ size, 75 cts. each, $\$ 8$ per doz., $\$ 60$ per $100 ; 3$ rd size, 50 cts. each, $\$ 5$ per loz., $\$ 40$ per 100 ; specimens, $\$ 2$ and $\$ 3$ each.

\section{Dwarf Rhododendrons}

The dwarf Rhododendrons are extremely attractive and desirable, beautiful both in foliage and flowers. The following varieties are perfectly hardy.

R. mysthyfolium. Lavender flowers, unspotted.

R. arbutifolium. Pale lavender flowers, dark foliage and red wand. Punctatum. Pink flowers.

$$
\$ 1 \text { each, \$10 per doz. }
$$

\section{Rhododendron maximum IN CAR-LOAD LOTS}

Rhododendron maximum, commonly known as the Large-leaved Laurel, grows wild over a large extent of territory in this country, but usually under such conditions that it is impossible to successfully transplant it. I have found a source of supply where, although the plants are growing wild, they are in as good condition as if growing in a nursery, and of course can be supplied at one-fifth the cost of nursery-grown stock. The value of this Rhododendron for planting in quantity in country places cannot be overestimated. It is perfectly hardy, thrives in sun, partial or full shade; extremely showy when in bloom in July, the large heads of flowers being white or blushwhite, and on account of its bold evergreen foliage is extremely effective throughout the year. It is fine for naturalizing in the woods or the edge of the wood. It has been used in this way by the hundred car-loads on the grounds of Mr. William Rockefeller, near Tarrytown, N. Y., and the head gardener there reports that the loss in transplanting did not average one plant to the car-load. My own experience has been the same. I have used great quantities on the grounds of my clients and practically have not lost a plant, and nothing I have used has been so immediately effective or satisfactory. Price on car-load lots furnished on application.

\section{Bedding Rose, Gruss an Teplitz \\ (CRIMSON HERMOSA)}

This, the reddest of all red Roses, is to the amateur, who has no greenhouse, and depends on his garden for flowers, one of the most important varieties yet introduced. It is a rose for everybody, succeeding under the most ordinary conditions. In color it is of the richest scarlet, shading to a velvety crimson as the flowers mature; in size it is larger than Hermosa, very fragrant, a free, strong grower, quite hardy, and a most profuse bloomer, the mass of color produced being phenomenal; the foliage is extremely beautiful,all the younger growth being of a bronzy plum color. We offer two sizes, all of which will flower freely this season. Selected size, strong 2-year-old plants, 40 cts. each, \$4 per doz. First size, strong 1-year-old plants, 25 cts. each, $\$ 2.50$ per doz., $\$ 16$ per 100 .

\section{Celastrus paniculata}

This is a comparatively new variety of Bittersweet from Japan. It is a beautiful vine of very rapid growth and fine foliage, and produces fruit much more freely than our native variety. The plants being male and female, one of each should be planted if fruit is desired. The fruit is orange-red in color and is extremely effective in the fall. 30 cts. each, $\$ 3$ per doz.

\section{Japanese Maples}

The Japanese Maples are of dwarf habit, rarely growing over 5 o 10 feet high, and are entirely hardy in the latitude of New Y ork. The rich and glowing color of the leaves in spring and carly summer makes them the most beautiful objects that can be planted on a lawn. A group of them during the months of May and June is a sight to b remembered. There are many varieties, all of which we can supply when desired; but the varietics offered below are the most beautifu and satisfactory of them all, and there is 110 place so small that should not have at least one of these cxquisite dwarf trees. The stock that we offer is American grown, and is much superior to the cheap imported Japanese stock, which I consider almost worthless.

Acer Japonicum aureum. 24 inches, from pots... \$2 50 polymorphum. Green-leaved. Makes a fine fully in the fall

Purple Cut-leaved. 24 ins. from pots.

Purple Cut-leaved. Large specimens. ..

Blood-leaved. 12 to 18 inches, bushy specimens.

Blood-leaved. Large specimens 400

Green Cut-leaved. Makes a splendid specimen. 24 inches from pots. .

Distinct and beautiful

Filicifolium. Specimens.

\section{Kalmia latifolia}

Kalmia latifolia. commonly known as Mountain Laurel, is the most beautiful of all evcrgreen shrubs. Like the Rhododendron it likes a light, loose soil that is free from lime, and will grow in either sun or shade but will flower more freely in the sun. The flowers are wheel-shaped and set in close corymbs on the end of the stems, pure white to pink, and appear in June in such profusion as to almost hide the foliage. It is only of late years that American planters have awakened to the beauty and value of this native shrub in all proper locations, though it has been highly esteemed and largely planted in Europe for many years. In numerous show places in England, the collection of "American plants," to which a visitor is conducted with pride, is made notable by our Mountain Laurel, which can so readily be established in proper locations anywhere in the United States. Collected specimens are not so useful as nursery-grown plants, which transplant with entire safety. Fine nursery-grown plants, 25 cts. each, $\$ 2.50$ per doz.; 50 cts. each, $\$ 5$ per doz.; 75 cts. each, $\$ 8$ per doz.; $\$ 1$ each, $\$ 10$ per doz.; $\$ 1.50, \$ 2$ and $\$ 3$ each, according to size.

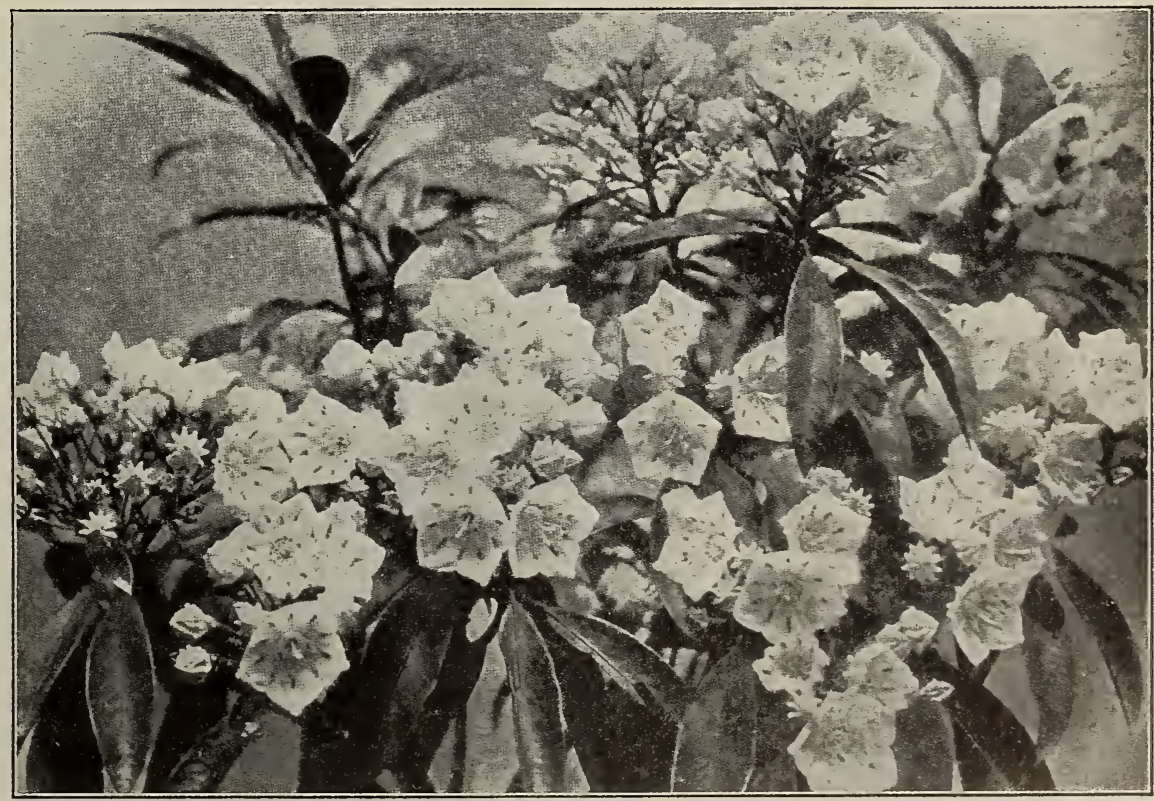

Kalmia latifolia 


\section{Special Offer of Gladioli}

Gladioli sent postpaid by mail for 10 ets. per doz. and 75 cts. per 100, in addition to prices quoted. Prices good until withdrawn. Delivery at any time from November until June 15

For cutting, for the decoration of the house, or for any purpose for which cut-flowers are used during the summer and fall months, no flower can be grown so satisfactorily as the Gladiolus. The spikes of flowers are large, showy and very beautiful, and last a week in water after cutting. By planting at intervals from April 1 to June 15, they can be had in blossom from June 25 until frost. For cutting purposes they can be grown in the vegetable garden or any convenient place, and, as they can be planted very closely, a large quantity can be grown in a very small space. They are of the easiest culture, failure being practically impossible, and it can be safely estimated that the bulb will increase at least 50 per cent every season. The bulbs can be wintered in any room or cellar that is free from frost. The bulbs offered below are strictly first-class, and are from the largest and best Gladiolus growers in the world.

Seeding Gladioli. Superb quality; all colors...... Per $\begin{gathered}100 \\ 25\end{gathered} \$ 1800$ Mixed Gladioli. Best quality; all colors......... $200 \quad 1500$

Red and Scarlet Gladioli. Splendid for massing in

shrubberies and borders................ 200

White and Light Gladioli. A choice mixture made from all named Gladioli; equal to what is generally sold at four times the price.

Pink Gladioli. Best quality
White and Light Gladioli. Finest quality Doz. 100 made up from the choicest named varieties........................ $\$ 075$

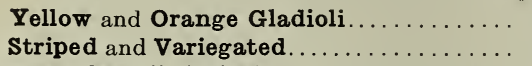
New Gladioli Childsii.

Best quality mixed. named varieties. . 10 to $50 \mathrm{cts}$. each, $\$ 1$ to .......... 500
1,000

$\begin{array}{lllll}75 & \$ 4 & 50 & \$ 40 & 00\end{array}$

$\begin{array}{lllll}70 & 5 & 00 & 45 & 00\end{array}$

$\begin{array}{lllll}60 & 4 & 00 & 30 & 00\end{array}$

$50 \quad 3 \quad 50$

\section{MIXTURE}

This is a specially fine mixture, made up of over 100 fine named varieties, and includes also a good percentage of Childsii $\mathrm{Hybrids}$ Just the stock for those who want only the very best that can possibly be had. First size, $\$ 3$ per 100 , $\$ 25$ per 1,000 .

\section{Gardening Books and Papers}

It is hardly now necessary to call attention to that splendid magazine Country Life in America, published by Doubleday, Page \& Co., of New York. This is hardly a gardening magazine, but considerable space is devoted to gardening matters and it is altogether the most beautiful and interesting magazine that we find on our library table. This magazine has been run on a liberal scale, the publishers believing that there is ample field for a magazine appealing to the better class of country-lovers. We are glad to say that their experience has borne out this hope, and the magazine has prospered so that it now has a regular circulation of above 50,000 copies. Its continuation on its present scale should be a satisfaction to every country-lover and every person connected with the country. The price is $\$ 4$ a year; it is printed on coated paper, most superbly illustrated, and in every way worth what the publishers charge.

The best book on gardening ever published, and worth more than all other books on gardening and landscape gardening, is Wm. Robinson's The English Flower Garden, now in its eighth edition. Whatever success we have made as landscape gardeners we owe to the inspiration of this book. It not only teaches good gardening but, what is quite as important, condemns bad, giving reasons that are convincing for both. This book has done more to improve the gardening in England than all other influences combined, and we wish it were in our power to secure its reading by all thoughtful, intelligent people in this country. The book is very comprehensive, treating of the arrangement of various styles of gardens, and contains descriptions of almost every tree, shrub, plant and bulb of value used in ornamental gardening. It is profusely illustrated by the best English artists with pictures made in hundreds of English gardens. The price is $\$ 6$. It may be ordered from any bookseller, or we will forward it on receipt of the price.

A delightful book recently published in England is Wood and Garden, by Miss Jekyll. The book hasn't much to say about culture, but is full of good suggestions for arrangement, and the illustrations, from photographs made by the author, are a delight, and should do much toward the banishment of ugly and inartistic gardens. It is charmingly written by an enthusiastic amateur, and should be read and owned by every lover of a good garden as well as by those who know nothing of the pleasures of a garden. The book can be obtained through any bookseller. A later book written by Miss Jekyll, Wall and Water Gardens, tells most interestingly of two of the most fascinating phases of gardening. The pictures are superb and should do much to improve the gardens of England and America. Still another book by Miss Jekyll is Lilies for English Gardens. A friend complains that he finds no good lily illustrations. Well, he will find them here, and the best and most exhaustive work on lilies yet written.

\section{THE GARDEN MAGAZINE A Monthly Magazine on TWENTY REGULAR DEPARTMENTS}

The Gardener's Reminder; Coldframes and Hotbeds; The Back Yard; Vegetables; Bulbs; Roses; Annual Flowers; The Small Greenhouse; The Water Garden; The Window Garden; Garden Insects; The Hardy Border; Recent Discoveries, etc. PRICE, \$1.50 A YEAR

\section{SPECIAL OFFERS OF THE GARDEN MAGAZINE}

No "1. The Garden Magazine for one year, and the beautiful book price of the book alone.

No. 2. To any order for plants, bulbs or shrubs, amounting to $\$ 1$ or more, a year's subscription to The Garden Magazine may be added for $\$ 1$.

No. 3. 12 Choice Hardy Plants, assorted, our selection of varieties, and the Garden Magazine for one year, will be sent for $\$ 2$.
No. 4. 12 Choice Aquilegias, in six finest varieties, our selection, and The Garden Magazine for one year, will be sent for $\$ 2$.

No. 5. 12 Choice Hardy Asters, best varieties, our selection, and The Garden Magazine for one year, will be sent for $\$ 2$.

No. 6. 12 Hardy Sunflowers (Helianthus), best varieties, our selection, and The Garden Magazine for one year, will be sent for $\$ 1.75$.

TEIE GARDEN MAGAZINE is the best gardening paper ever published. Our customers can find nothing else so helpful 


\section{Formation of Lawns from Seed}

The ground should be thoroughly drained and well prepared. The soil ought not to be too rich, as a rapid growth is not wanted in the grasses of a lawn, but the surface should be as much alike in quality as possible. After sowing, the ground should be rolled, in order to press the seed firmly into the soil. The proper time to sow grass seed depends, of course, upon the latitudes. In the central and eastern states, from September 15 to October 15 is the best time. Seed may also be sown in the spring, provided it is done early enough to secure a good, strong growth before the lot, dry weather of summer sets in. The sowing should be done when the ground is moist, or before an expected rain, and a subsequent rolling is always advisable.

Rolling.-As soon as the frost is out of the ground in the spring the land should be gone over with a heavy roller. Winter frosts loosen the soil, and rolling is necessary to compress it again. If grass seed is to be sown, this should be done first and the rolling immediately afterward. Frequent rollings are recommended.

Mowrvg.-All turf-forming grasses are improved, both in vigor of root-growth and fineness of texture, by frequent mowings. It is impossible to say just how often the grass should be mown, as that depends upon the rate at which it grows. Too close cutting should be guarded against, however, especially during the hot summer months, when the roots require some top-growth to protect them from the burning sun. A good top-growth is also necessary to protect the roots from the severe winter frosts. Mowing should, therefore, be discontinued in time to let the grass grow pretty long before winter sets in.

To Grass a BaNk or Terrace.-For each square rod

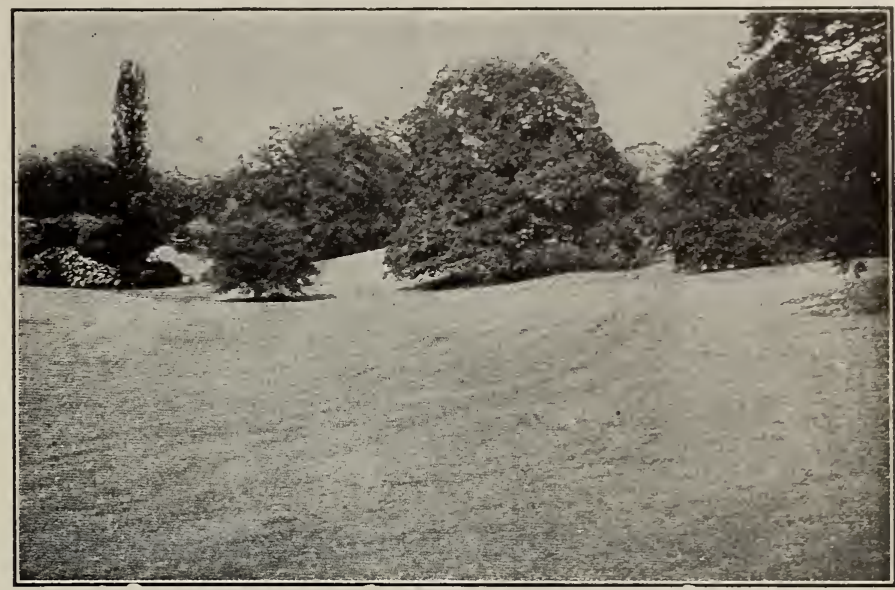
take a pound of lawn grass seed and mix it thoroughly with six cubic feet of good, dry garden loam. Place in a tub and add liquid manure diluted with about two-thirds of water, so as to bring the whole to the consistency of mortar. The slope must be made perfectly smooth, and then well watered, after which the paste should be applied and made as even and as thin as possible.

\section{PRICES OF GRASS SEED}

We can supply the very best quality of Mixed Lawn Grass Seed for $\$ 1$ per bushel. This is exactly the same quality of seed that is

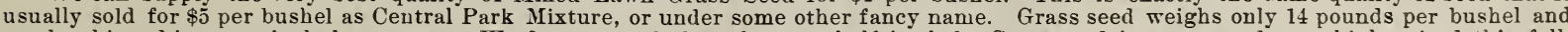
can be shipped inexpensively by express. We do not supply less than one-half bushel. Grass seed is scarce and rery high priced this fall. Grass seed is sold by weight, 14 pounds for a bushel; but 14 pounds of clean grass seed will not fill a bushel. Grass seed can be sown advantageously in the fall, preferably in September. Prices: $1 / 2$ bushel, $\$ 2.10 ; 1$ bushel, $\$ 1 ; 10$ bushels, $\$ 3.75$ per bushel; 25 bushels or over, $\$ 3.50$ per bushel. Small quantities shipped from here; large quantities from Cincinnati.

\section{Low Prices for Hydrangeas}

No more popular plant or shrub has ever been sent out than Hydrangea paniculata grandiflora, and we take great pleasure in offering our customers a large stock of splendid vigorous plants at such extremely low prices as will enable them to plant this effective shrub in quantity. People who have only seen this Hydrangea grown singly as specimens have no conception of how beautiful and effective

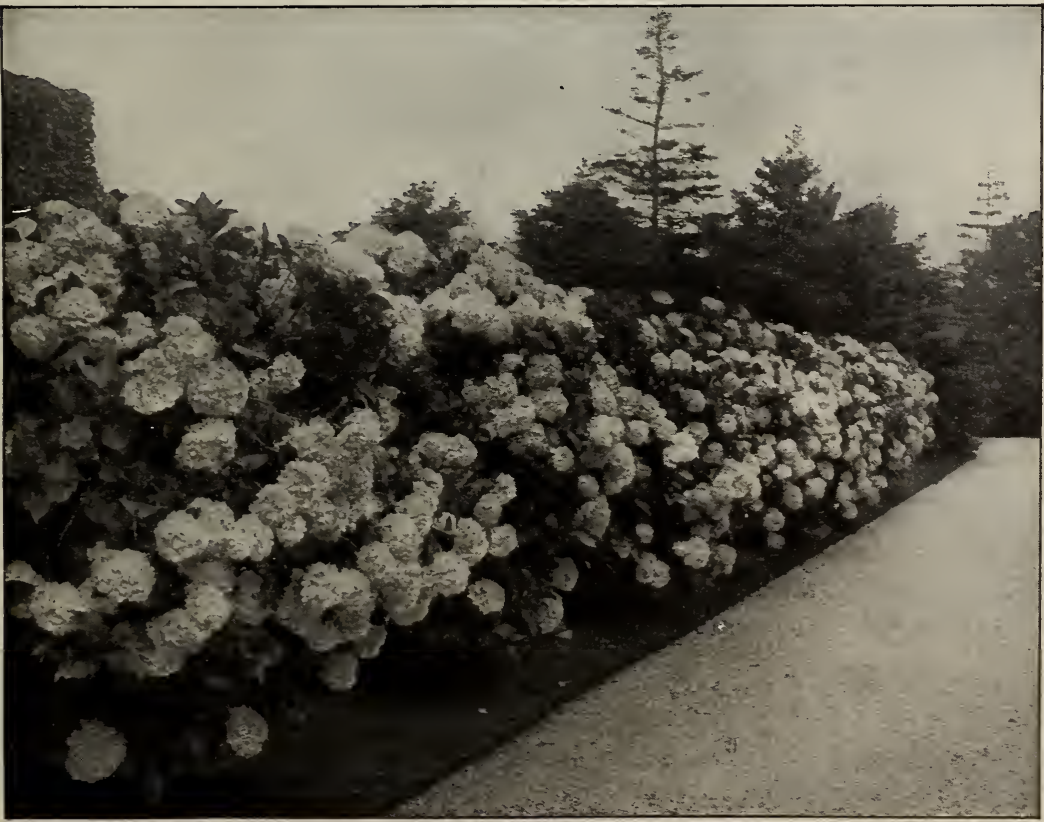

Border of Hydrangeas they are when planted in masses. They are planted in this way at Newport, R. I., which is famous for its fine gardens, and almost as famous for its Hydrangeas. These Hydrangeas can be planted in connection with other shrubbery or in isolated beds, in the same manner as cannas, caladiums or other strong-growing bedding plants. They are perfectly hardy, and, once planted, they are a permanent addition to the lawn or garden. When grown in beds or groups they should be planted about 2 feet apart, in very rich soil, which should be liberally enriched annually with rotten stable manure; and in the early spring, before they commence to grow, cut back so as to leave only two or three inches of the new growth of the previous season, and, if extremely large flowers are desired, cut out some of the weaker shoots after growth has commenced. Treated in this manner they will produce enormous panicles of flowers, and the beds will be a solid mass of bloom. They bloom profusely the same season planted. Try them. You will find them more than satisfactory. Prices good until stock is exhausted. Fall or spring delivery.

Hydrangea paniculata grandiflora-

18 to 24 inches... \$ \$3 $50 \$ 6 \quad 50 \$ 1200$ 2 to $3 \mathrm{ft}$.

large and bushy. $500 \quad 8 \quad 50 \quad 1500$

All of the above will bloom the first year, and are superior to the stock commonly retailed at $25 \mathrm{cts}$. to $\$ 1$ each.

It is suggested that when smaller quantities are wanted, two or three club together in ordering. For prices on smaller quantities. see list of Hardy Shrubs. 


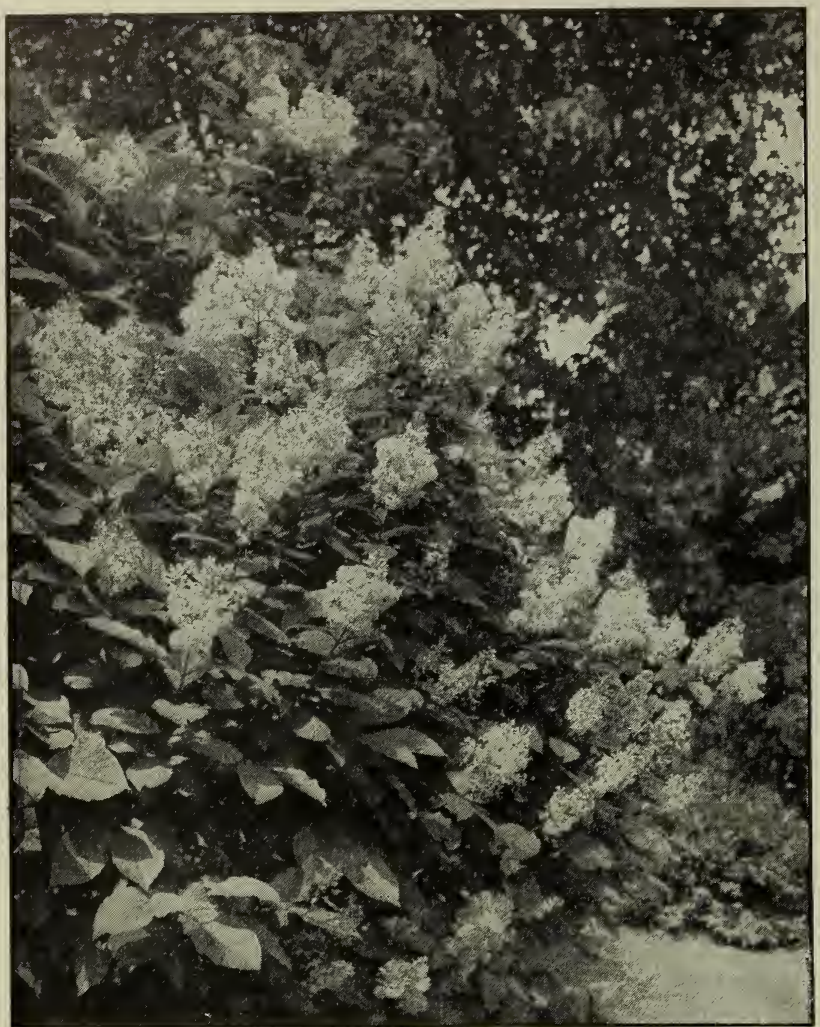

Syringa villosa lutea

Dr. Masters. Double; lilaceous.

Dame Blanche. Double; white. \$1.

Emile Lemoine. Double; very large flowers, of fine globular form; rosy lilac. Beautiful.

Geant des Batailles. Bright reddish lilac, in large trusses. $75 \mathrm{cts}$.

Grand Duc Constantine. Ashy lilac; double.

Jeanne d'Arc. Double; enormous spikes; pure white flowers, large and full; buds creamy white.

La Ville de Troyes. Large, purplish red flowers; fine. $75 \mathrm{cts}$.

La Tour d'Auvergne. Double; purplish violet. $\$ 1$.

Le Gaulois. Rosy lilac; a very lovely variety. 50 cts.

Lemoinei. Rose, turning to lilac; double.

Lemoinei ff. pl. Double; carmine-violet.

Leon Simon. Double, compact panicles; flowers bluish crimson.

Madame Lemoine. Superb; double; white. $\$ 1$.

Madame F. Morel. Violet-pink; large and fine; single.

Madam Casimir-Perier. Creamy white; lovely double.

Mad. Abel Chatenay. Double; milk-white. $\$ 2$.

Marie Legraye. Large panicles of white flowers. The best white Lilac. $75 \mathrm{cts}$.

Michael Buchner. Dwarf plant; very double; color pale lilac. $\$ 1$.

Negro. Very dark violaceous purple.

President Carnot. Double; lilac tint, marked in center with white. $\$ 1$.

Rothomagensis. Violacenus lilac. $35 \mathrm{cts}$.

Souvenir de Louis Spæth. Most distinct and beautiful variety; trusses immense; very compact florets, very large; the color is deep purplish red. \$1.

Villosa Lutea. A late-flowering species, blooming a month later than other varieties, with deep pink flowers; extremely free-flowering and effective. Makes a large splendid specimen. $\$ 1$.

Viviand Morel. Long spikes; light bluish lilac, center white; double. Wm. Robinson. Double; violaceous pink.

\section{New Lilacs on Their Own Roots}

Of late years there has been a multitude of new varieties of lilacs grown, and some of them have very great beauty, but, unfortunately, almost all the stock offered, both in this country and Europe, has been budded on privet and is practically worthless, for Lilacs grown on this are certain to die in a few years. Nurserymen bud Lilacs on privet because they can produce a large stock quickly and inexpensively, but one Lilac on its own roots is worth a score of budded plants.

Ten years ago we bought all the available stock of choice named Lilacs on their own roots in Europe, and since then we have been both growing and buying until we have a very large and fine stock, and the only stock of named Lilacs grown on their own roots, in America.

Price, except where noted, $\$ 1.50$ each, $\$ 15$ per doz. Amethystina. Very dark reddish purple.

Alba grandiflora. Very large, pure white trusses of flowers.

Alphonse Lavalle. Double; large panicles; blue, shaded violet. $\$ 2$. A. W. Paul. Red, back of flower whitish.

Bertha Dammann. Pure white; very large panicles of flowers; fine. $\$ 2$.

Charles $\mathbf{X}$. Large, shining leaves and great trusses of reddish purple flowers. $50 \mathrm{cts}$.

Charles Joly. A superb dark reddish purple variety; double. $\$ 1$.

Congo. Bright wallflower red. $\$ 1$.

Dr. Lindley. Large, compact panicles of purplish lilac flowers; dark red in bud; very fine.

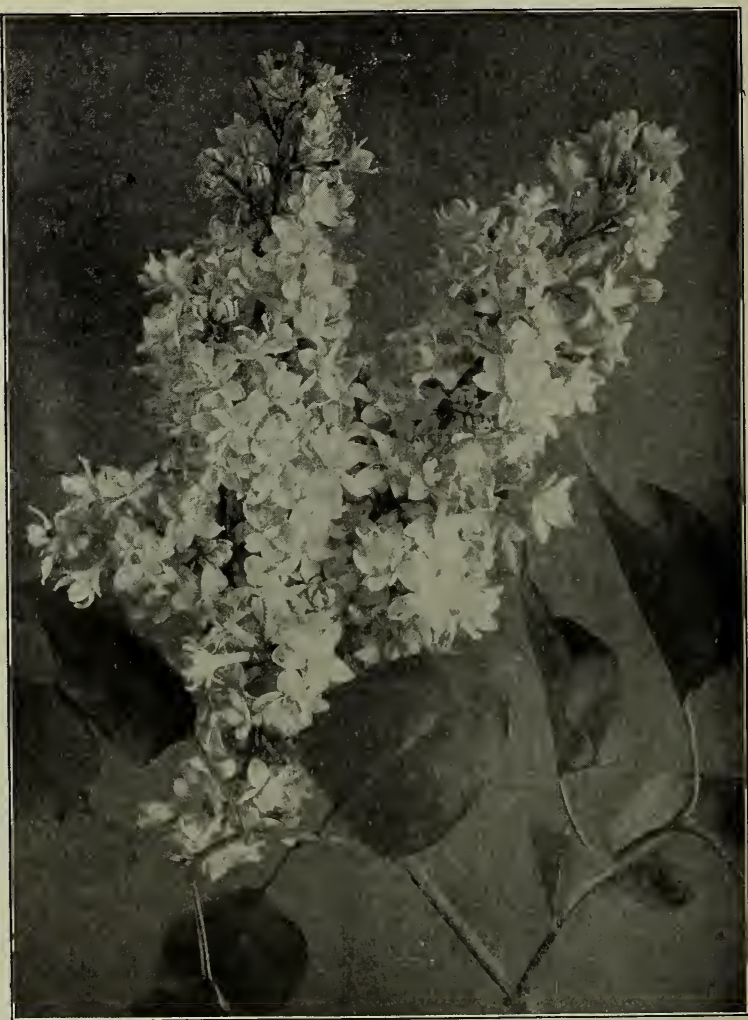

New Lilac, Marie Legraye 


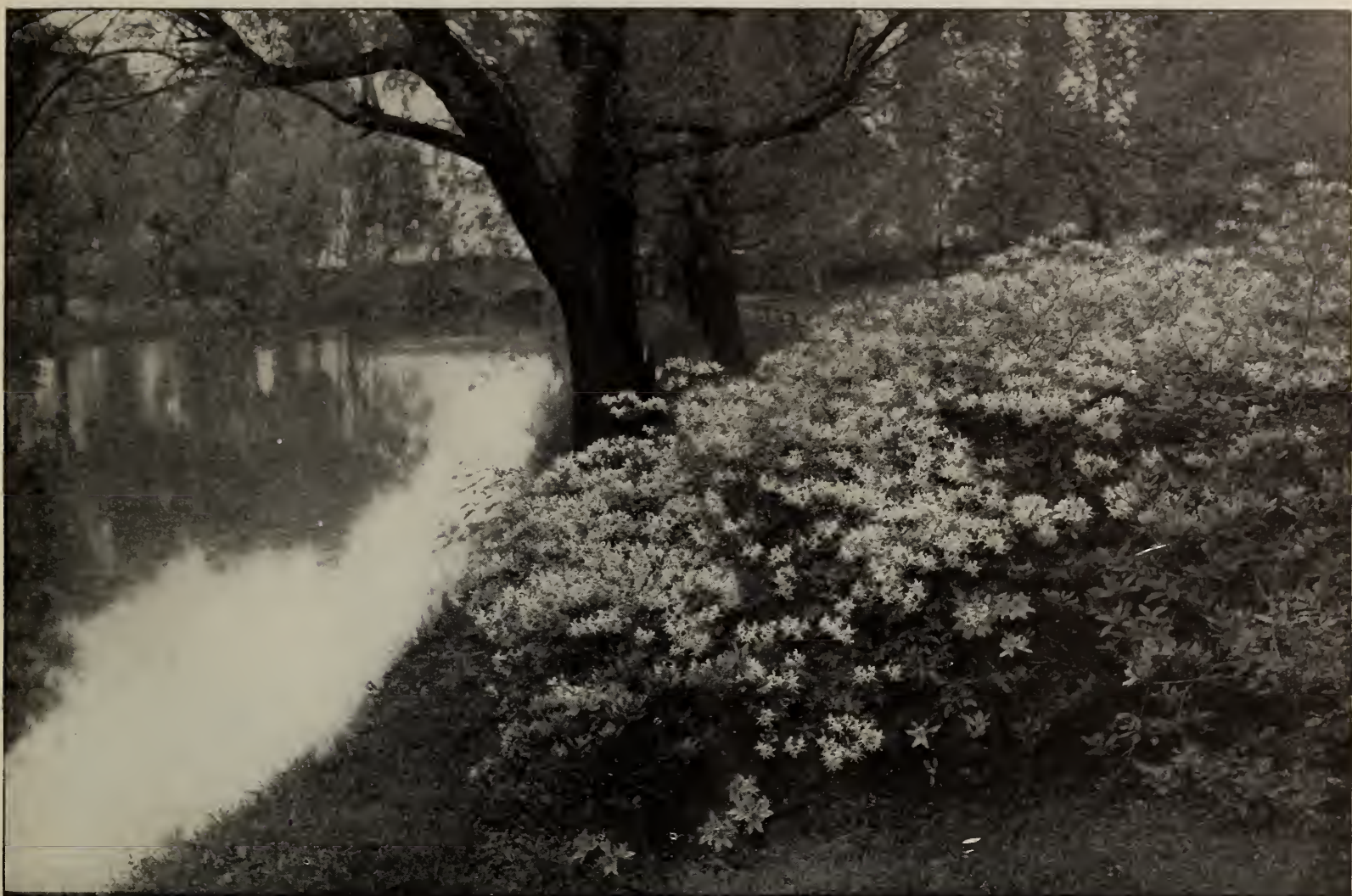

Azalea Nudiflora (see page 20)

\section{HARDY AZALEAS}

We make a specialty of Hardy Azaleas, and have undoubtedly the largest collection and best stock in America. The Azaleas are the most beautiful and desirable flowering shrubs in cultivation and a collection should be included in every garden. Azalea mollis is especially valuable on account of its very showy bloom, hardiness and ease of culture, being quite as easy to grow as the commonest shrubs. All Azaleas can be grown in partial shade, and the native varieties are fine for naturalizing. We wish to call especial attention to the value of our Native Azaleas. There is nothing in flowering shrubs more beautiful, and they are of the easiest culture, being much hardier than the imported varieties. For naturalizing, for the shrubbery or as individual specimens they are unsurpassed, and on large grounds they should be planted by the hundred.

\section{Azalea mollis}

We take special pleasure in offering an exceptionally nice lot of small Azalea mollis at a price much less than ever made before. The plants are hardy and in fine condition, and, with the exception of the small plants, are well set in bloom buds. Azalea mollis is of comparatively dwarf, bush-like habit, with light green leaves, which are somewhat larger than those of other Azaleas.

The flowers are as large as the Indian Azaleas usually seen in greenhouses, being $2 \frac{1}{2}$ to 3 inches in diameter, and appear in bunches on the ends of the shoots. The colors are of various shades of yellow and red, and they expand about the middle of May.

We know of no other flowering shrub to equal them in attractiveness, and when massed in a large bed they create a particularly beautiful spot on the lawn. They are also very effective when planted around the edges of rhododendron beds, as the dark green leaves of the rhododendrons make a strong background for the bright colors of the Azaleas. They are also valuable for mixing in beds with the Azalea Pontica (Ghent Azalea), as they bloom a little in advance of the others.

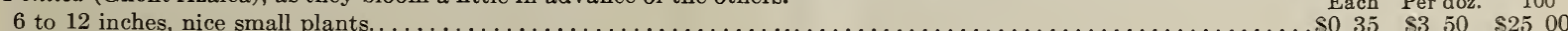

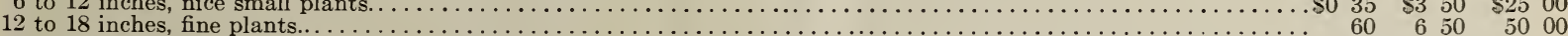

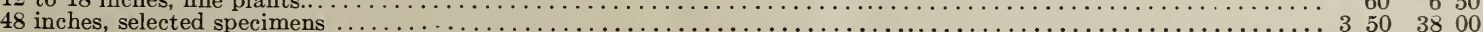

\section{Ghent Azaleas}

The following were imported from the best Azalea nurseries in Europe, and have since been grown in this country. They. are exceptionally fine plants and well set with bloom buds. The Ghent varieties are the finest of all Azaleas, and should be made a feature of every garden. The flowers, sweet-scented, are produced in the greatest profusion and range in color from white to deep crimson through all shades of pink and yellow. Ghent Azaleas require a light soil, and should be kept well watered during a dry time.

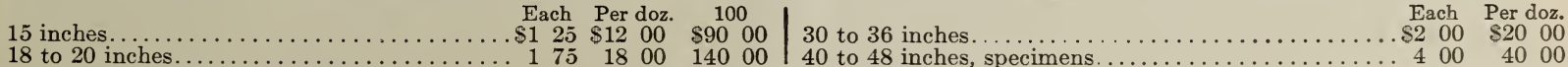

Special Offer of Large Ghent Azaleas. We have too large a stock of large specimen Ghent Azaleas. They are splendid, $3 \frac{1}{2}$ to 4 feet high and well worth $\$ 4$ to $\$ 5$ each, but until our stock is sufficiently reduced we will fect safety. We reserve the right to withdraw this offer at any time. $\$ 24$ per doz., $\$ 190$ per 100 . Six at the doz, rate, 50 at the 100 rate. 


\section{Native and Other Azaleas}

Our native Azaleas are easily among the most beautiful flowering shrubs in the world, but hitherto it has been impossible to get good plants of them, as the stock generally offered is newly collected from the woods and very unsatisfactory. The following stock we have had specially grown for our customers, and it is strictly first-class and in splendid condition, and many of the plants well set with bloom buds.

AZALEA arborescens (Native). Splendid foliage, throughout the summer. Large, white, sweet-scented flowers; the latest Azalea to bloom; fine plants. 18 inches, 50 cts. each, $\$ 5$ per doz.

Amoena. A dwarf, compact evergreen variety, with rosy purple flowers; makes a beautiful specimen or can be used for an ornamental hedge. 50 cts. each, $\$ 5$ per doz., in 4 -in. pots; 75 cts. each, $\$ 8$ per doz., in 5 -inch pots.

Calendulacea (Native). Great Flame-colored Azalea. Flowers vary from deep crimson to bright sulphur-yellow; very showy. Fine plants, 18 to 24 inches, 75 cts. each, $\$ 8$ per doz., $\$ 65$ per 100: 36 to 48 inches, $\$ 1.50$ each, $\$ 15$ per doz., $\$ 100$ per 100 .

Canescens. A lovely native variety with bright pink flowers. Very sweet-scented and the first to bloom. $\$ 1$ each, $\$ 10$ per doz.

Hinodegiri. This new Azalea is similar to A. amcena but hardier, and the flowers are much more brilliant. It makes a beautiful
Azalea Hinodegiri, continued

dwarf evergreen shrub. The flowers produced in the spring are a bright fiery red. 5-inch pots, $\$ 1$ each, $\$ 10$ per doz.; 4 -inch pots, 75 cts. each, $\$ 8$ per doz.

Nudiflora (Native). This is the Azalea found so plentiful in the Pennsylvania mountains and along the Allegheny river, and commonly known as the Wild Honeysuckle. Lovely pink flowers produced in the greatest profusion. One of the most desirable shrubs in cultivation. $75 \mathrm{c}$ each, $\$ 8$ per doz., $\$ 60$ per 100 .

Vaseyi (Native). This lovely Azalea has attracted a great deal of attention lately, especially in England, where it is highly prized. The flowers appear before the foliage in April in the greatest profusion and vary from blush to deep pink. This Azalea will in time grow to be 12 or 15 feet high. 75 ets. each, $\$ 8$ per doz.

Viscosa (Native). A dwarf variety with white flowers; nice plants, 24 to 36 inches, 75 cts. each, $\$ 8$ per doz.

\section{Rhododendrons}

We believe we are the largest importers of these splendid evergreen shrubs in this country, and offer a very superior quality of plants. The varieties we supply are of unquestioned hardiness, and are certain to give first-class results when properly planted. They require a deep and light soil, and a bed for them should be dug out to the depth of 2 feet and filled in with light loamy soil mixed with one-half its bulk of turfy sods chopped up fine. No manure should be mixed in the soil, but an annual mulching of cow manure is beneficial.

We will also quote very low prices on Rhododendrons by the 100, to be imported to order; orders not to be received later than March 1 . Best Named Varieties. About 18 inches high; good bushy plants, set with bloom buds. $\$ 1.50$ each, $\$ 16$ per doz.

Best Named Varieties, Selected. 24 to 30 in., $\$ 2.50$ each, $\$ 27$ per doz.

Specimens, $\$ 5, \$ 8, \$ 10, \$ 15, \$ 20$ and $\$ 25$ each, according to size. Imported to order only

\section{HERBACEOUS PEONIES}

It gives us great pleasure to see the increasing popularity of Peonies, for there is nothing more deserving, and when the merit and beauty of the newer varieties are known every garden will contain a large collection. Like the Irishman's whiskey, all varieties of Peonies are good, even the commonest old-fashioned sorts, but there is no language to describe the glorious beauty of the finest of the newer varieties. In no other flower has there been such a marked improvement, and they actually surpass the rose in size, form and coloring, and their ease of culture and extreme hardiness are too well known to enlarge upon. Always having a keen appreciation of these superb flowers, we have for years collected all the varieties obtainable in the world, and now have the largest collection of varieties and the most extensive stock in America. Peonies planted in August or September will bloom the following season. Of many varieties offered in the following list, we can supply large undivided clumps at from three to five times the prices quoted-prices depending upon how many salable plants the clumps would make if divided. By planting these undivided clumps a fine display of flowers can be had next season. Price-list of undivided clumps sent on application.

\section{Tree Peonies}

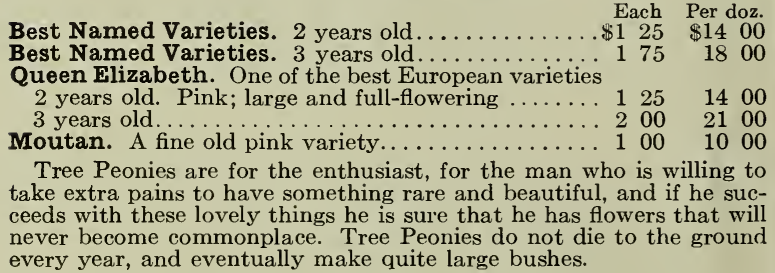

\section{Japanese Peonies}

Double and Semi-Double. Fine varieties. Each Per doz. 100

These are really very choice and distinct

from varieties grown in this country and will

give the greatest satisfaction.

$\begin{array}{llllll}\$ 0 & 60 & \$ 6 & 00 & \$ 45 & 00\end{array}$

Single. Fine varieties. The finest Single

Peonies undoubtedly come from Japan.

They are equal or superior to single sorts com-

ing from Europe costing three times as much.

$\begin{array}{lll}70 & 7 & 50\end{array}$

5500

\section{Choice Named Peonies}

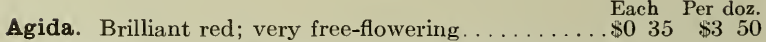
Arthemise. Large flowers; lovely soft rose and salmon, very beautiful...

Albert Crousse. Immense flowers; very full; fresh
CHOICE NAMED PEONIES, continued

Asa Gray. Large, full flower; imbricated; beautiful Each Per doz. form; carnation-salmon, powdered with carmine-lilac.

One of the best......................... 50

Avalanche. Large flowers of perfect shape; milk-white, creamy center with a few carmine stripes; late and very free-flowering; splendid habit. A variety of great distinction and beauty (see illustration, p. 22). 150

Armandine Mechin. Large; blooms in clusters; very brilliant, clear amaranth, extra ............ $50 \quad \$ 500$

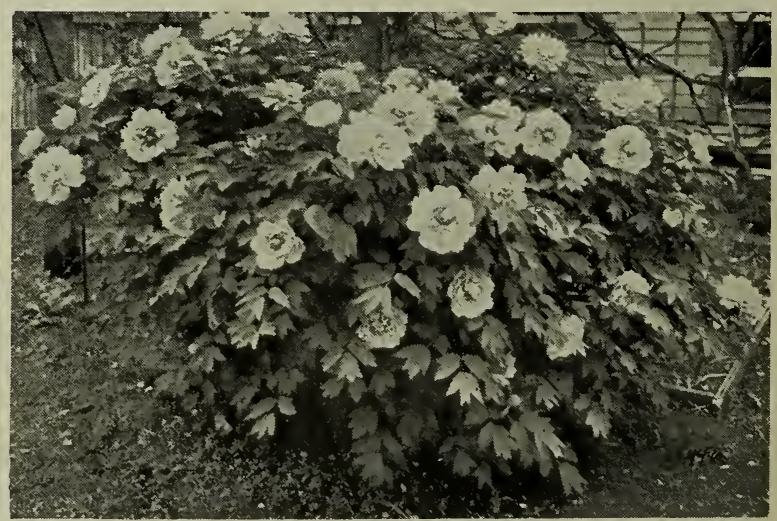

Specimen Tree Peony 


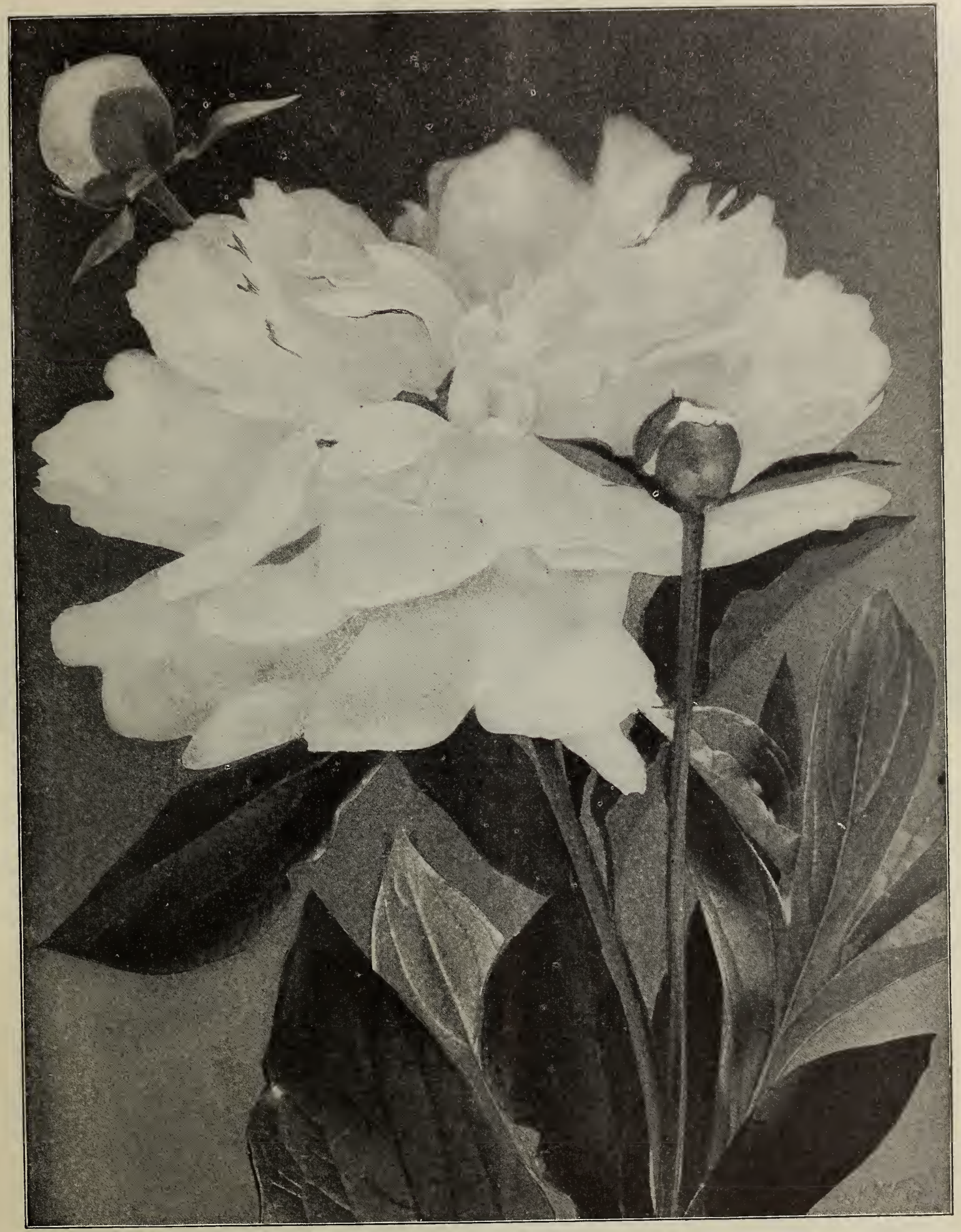

PEEONY FESTIVA MAXIMA

One of the finest white Peonies in cultivation. See special offer, page 22

(21) 


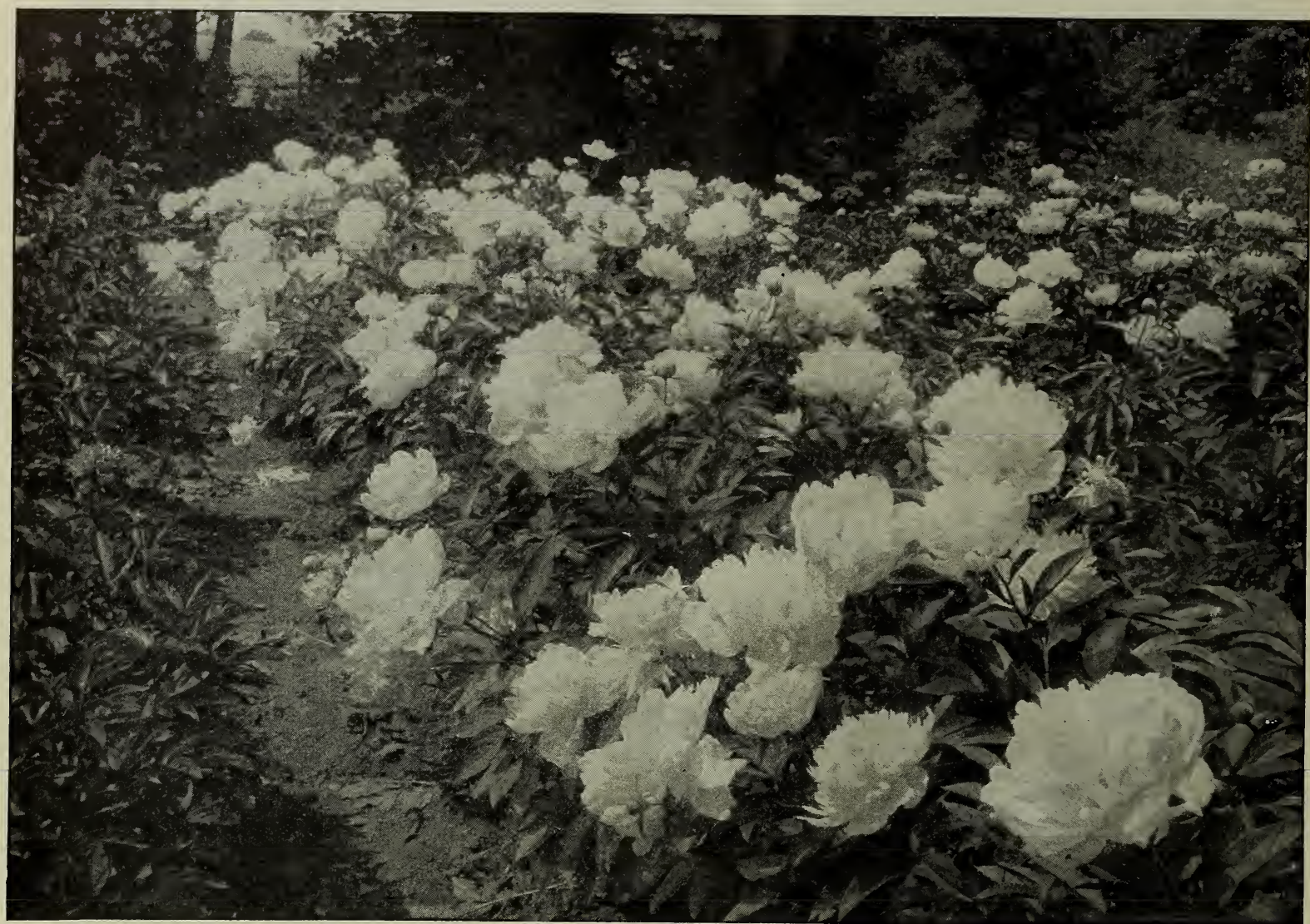

Avalanche Peonies (see page 20)

CHOICE NAMED PEONIES, continued

Ambrose Verschaffelt. Large, cup-shaped bloom; Each Per doz. deep crimson-purple......................

Augustin d'Hour. Large blooms; scarlet-purple, with silvery reflex.

Boule de Neige. Large, cup-shaped flower of perfect shape; white, lightly sulphured, center bordered with

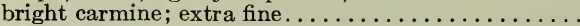

Beranger. Large, cup-shaped, imbricated flower;

mauve, shaded pink; late variety .......................
Beaute Francais. Delicate flesh-pink, with white and carmine spots............................................ with carmine reflex; golden stamens. Very elegant variety.

Couronne d'Or (Golden Crown). Large, imbricated white flower, yellow reflex, with stripes of carmine and golden stamens; extra fine. One of the very best late.

Curiosity. Large petals of clear violet-red, those of the center transformed into golden ligules; very distinct and pretty variety

Charlemagne. Large flower, creamy white, shaded chamois

Claire Dubois. Large, globular flowers, very full, most beautiful pink, glossy reflex. Very fine

Caroline Allain. Guard petals clear rose. Center flesh and salmon

$35 \quad 350$

White with sulphurish center. Doyene D'Enghien. Rose-violet, very dark, prettily veined.

Descartes. Very large flower; brilliant clear amaranth Dr. Bretonneau (Verdier). Large, globular flower; large rose petals and clear white; beautiful ..

Duchesse de Nemours (Calot). Very beautiful cupshaped flower; sulphur-white with greenish reflex; pretty bud; extra fine.....................

\section{Dugueslin. Rosy carmine.}

Dorchester. Cream-color, tinged pink; very double;

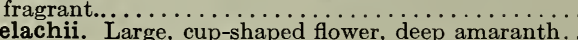

Delachii. Large, cup-shaped flower, deep amaranth..

Edulis superba. Very large flowers of perfect shape beautlful, brilliant tinted violet mixed with whitish

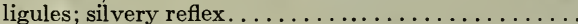

Edouard Andre. Large globular flower. Deep crimson red shaded black, with metallic reflex; stamens goldyellow, magnificent coloring, producing grand effect.

Electra. Extra-large flower. Light crimson shading to pink; yellow center; very good................... Felix Crousse. Enormous flower; brilliant red; extra..

Festiva. Dwarf; pure white, center carmine-spotted the same as Festiva Maxima but dwarf. An excellent white variety....

Festiva maxima. Very large, pure white flowers, with some blood-red stains in center; tall stalks; beautiful foliage, and very free-flowering. One of the very best white Peonies in cultivation. (See illustration, p. 20). Small Plants

Clumps.

F. B. Hayes. Enormous globe-shaped, soft pink flowe Fioral Treasure. Soft rose; ligules buff, with tufts of rose petals in center; distinct and fine; fragrant

Formosa. Pretty convex flower, yellowish white; bright red stigmas . . . . . . . . . . . . . . . . . Faust. Anemone-flowered, guard petals, soft lilac center; flesh shaded chamois.................... flowers; very rich. . . . . . . . . . . . . . . . . . . General Cavaignac. Lovely lilac-pink, shaded clearer

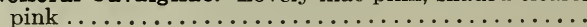

Each Per doz. $\$ 0 \quad 40 \quad \$ 400$

\section{0}

30

300

30

300 


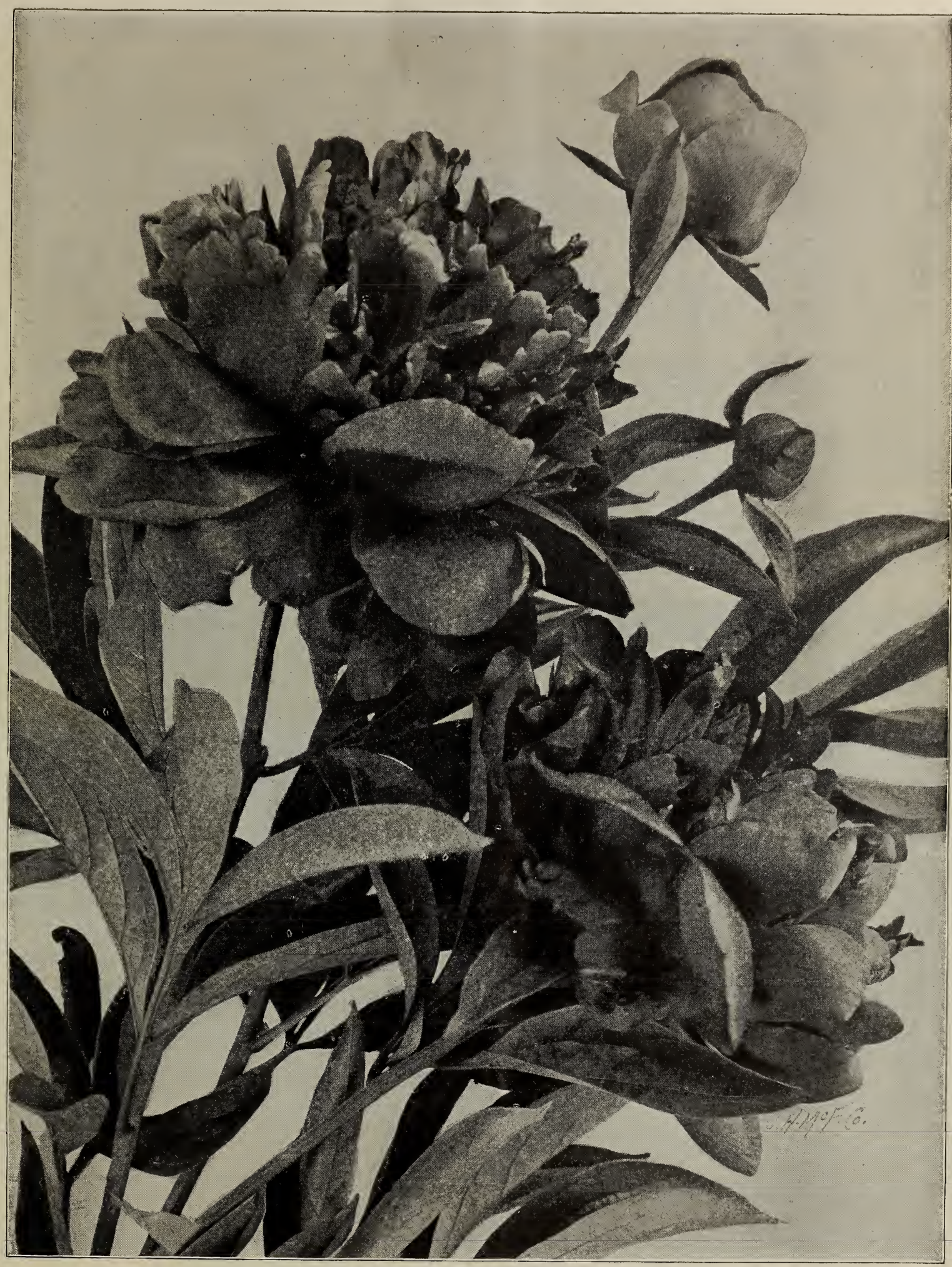

PEONY, RUBRA SUPERBA

(23) 
CHOICE NAMED PEONIES, continued

Each Per doz

Gloire de Charles Gombault. Pretty globular flower, extra full; deep fleshy pink collar, center petals salmoned clear fleshy color, shaded apricot with tuft of petals pink striped with carmine; multicolor variety of lovely coloring.

General Bertrand. Guard petals violaceous pink; center shaded salmon

Goliath. Enormous rose-pink flower ................ 200

Gubretæ. Single flowers; rich carmine, bright yellow stamens; extra fine.

Humei rosea. A splendid old sort, with deep rose flowers; one of the latest to bloom.

Hon. B. F. Jones. Semi-double outer petals white; center filled with yellow stamens resembling a water lily; very lovely

La Tulipe. Very large, globular flower; rosy white center, outside of the flower lively carmine, center striped deep carmine; extra fine.

Louis Van Houtte. Large flower of lively violet-red; very brilliant; a very beautiful variety. .

Lutea variegata. Fleshy white, shaded yellow. . .

La Rosiere. Imbricated petals, straw-yellow center, yellowish white border; similar to a tea rose...

La Fayette. Large, imbricated flower, fringed petals, velvety purplish pink, with silvery reflex; extra. .

Lady Leonora Bramwell. Silvery rose; fragrant.... .

L'Eclatante. Carmine; very beautiful...

La France. Enormous double, apple-blossom-pink flowers

Livingston. Large flowers, soft pink, washed with white; center touched carmine; lovely.

Lacepede. Single flower. Light crimson, yellow center; extra good form.

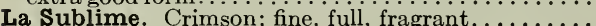

$\$ 050$

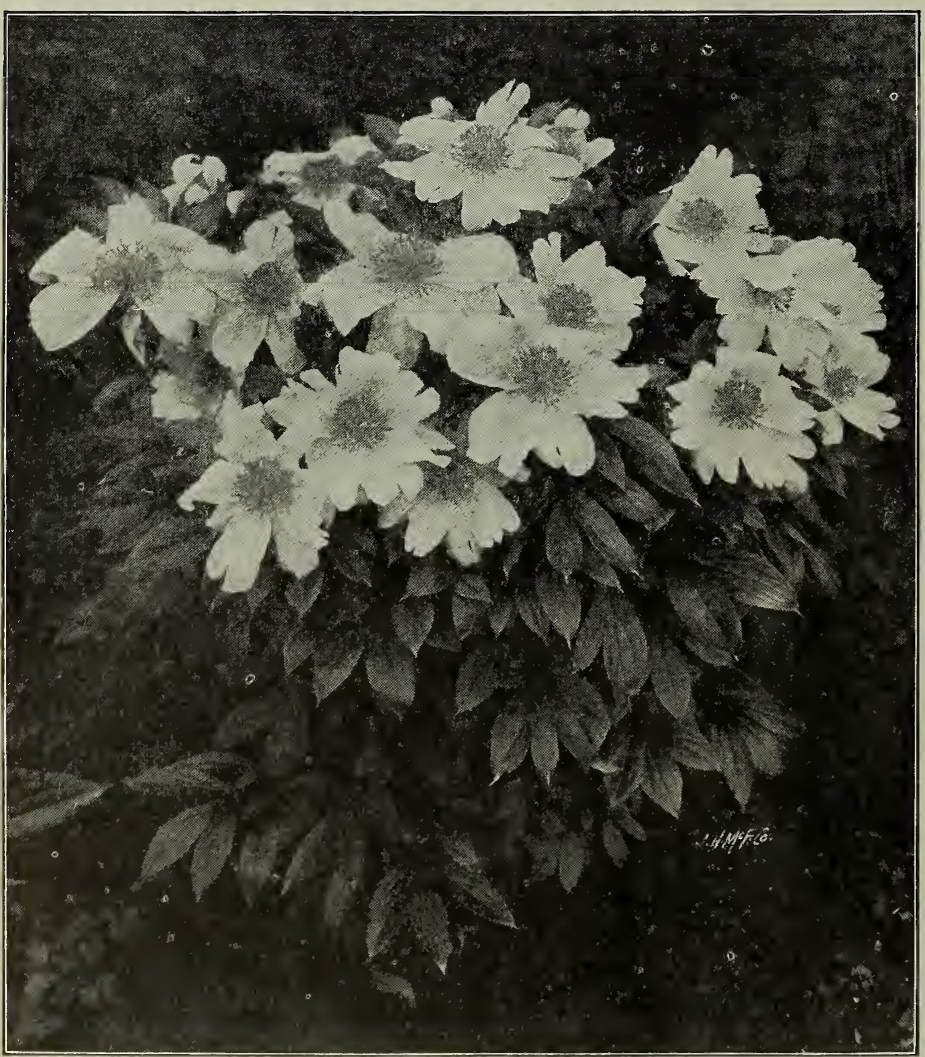

Single Peonies
Marie Lemoine (Lemoine). Extra-large, free-flower- Each Per doz. ing; ivory-white

M. Martin Cahuzac. Large, purple-red, shaded with black-maroon; very brilliant, and the darkest variety in cultivation; extra fine.......................... carnation-white, tinted yellow.

Mme. Chaumy. Large flowers in cluster; rose-shaded, large silvery border; very late variety ............. Mme. de Verneville. Very pretty anemone flower, very full; collar of large petals, those of the center very close; carnation-white and sulphur, sometimes carmine; extra.

Mme. de Vatry. Very large flower of perfect shape; color clear carnation; sulphur-white center with carmine stripes; extra-fine variety...

Madama Montot. Large flower, broad petals; bright cherry-carmine with silvery reflex on the border...

Marie. White, washed with chamois; very late variety Modeste Guerin. Broad flower; outside rose, center pink

Marguerite Gerard. Lovely light pink; one of the most exquisitely beautiful Peonies in cultivation....

Mlle. Leonie Calot. Soft salmon-flesh, occasional petal tipped carmine; fragrant....................

Magnifica. White, center yellowish.............

Madame Bucquet. Velvety black amaranth, coloring extremely dark and rich.....................

Madame Geissler. Glossy silvery pink...........

Marie Stuart. Soft pink and sulphury white; early; extra.

Nivea plenissima. Yellowish white, stained carmine; dwarf plant

Noemie. White, shaded flesh; very fresh coloring.... Numillo. Semi-double; dark crimson, reverse of petals shaded with purple;

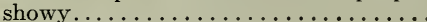

Officinalis. Single; white.......... Officinalis alba (Old Double White). Blush-white; early-flowering.......... Officinalis rosea (Old Double Rose). Rich bright shining rose; very early...

old Double Crimson. This fine old Peony is very effective when planted in masses; one of the earliest to bloom. $\$ 20$ per $100 \ldots \ldots \ldots \ldots \ldots \ldots \ldots$.

Octave Demay. Very large flower, very delicate pink, with narrow collar of ribbon-like white petals, center deeper flesh with occasional purple petaloids. Fragrant and good keeper; dwarf and distinct............................ fading to flesh; fine and fragrant. .....

Philomele. Soft satiny rose-color, center composed of saffron-yellow ligules tufted lively red; an elegant flower of remarkable freshness................

Prince de Salm Dyck. Lovely lilac, chamois center, tufted lilac ..........

Princess Galitzen. Soft carnation, very narrow center, petals of sulphur-yellow; fine ..............................

Petite Renee. Very large flowers in clus-
ters, clear carmined purple, central petters, clear carmined purple, central pet-
als very narrow, clear carmine striped white, golden extremities, yellow background. Very striking variety and very showy; extra fine................

Preciosa nova. Yellowish white, washed with bright carmine..............

Pottsi plena. Fine crimson-purple.....

President Roosevelt. Perfectly shaped; double flower, dark red .

Rubra superba. (Richardson). Grand globe-shaped flower; purplish crimson; very late. One of the finest reds in

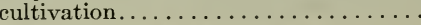

Rubra Triumphans. Crimson-purple... 
CHOICE NAMED PEONIES, continued

Reine Victoria. Carnation-white, center clear ycllow, Each Per doz. red stamens.. Ca.................. 25 \$2 50

Rose d'Amour. Large flower of very sof t carnation pink; very fresh color; fine

Solfaterre. Collar of large, pure white petals, those of the center narrow and sulphur-yellow. One of the best.

Souvenir de l'Exposition du Mans. Large flower; beautiful lively violet-red, with brilliant silvery reflex; extra fine.

$\begin{array}{llll}25 & \$ 2 & 50\end{array}$

$\begin{array}{lll}75 & 7 & 50\end{array}$

Sara Bernhardt. Large flowers of fine cffect; corolla of large petals, lively violet-rose, center salmon

Sulphurea. White, shaded with light sulphur. Very chaste...

Souvenir de i'Exposition Universelle. Clear cherry rose. very brilliant.

Tenuifolia. Same as following variety, but with beautiful single flowers.

Tenuifolia flore pleno. Deeply eut, fringe-like foliage; flowers bright searlet-crimson; rare and fine.

Triomphe de l'Exposition de Lille. Large, imbricated flower; soft carnation-pink, with white reflex, carmine center; very fresh coloring. One of the best.

Triomphe du Nord. Violet-rose, lilac shade.

Triumphans Gandavensis. Large flower, pinkish white, shaded chamois; good habit..............

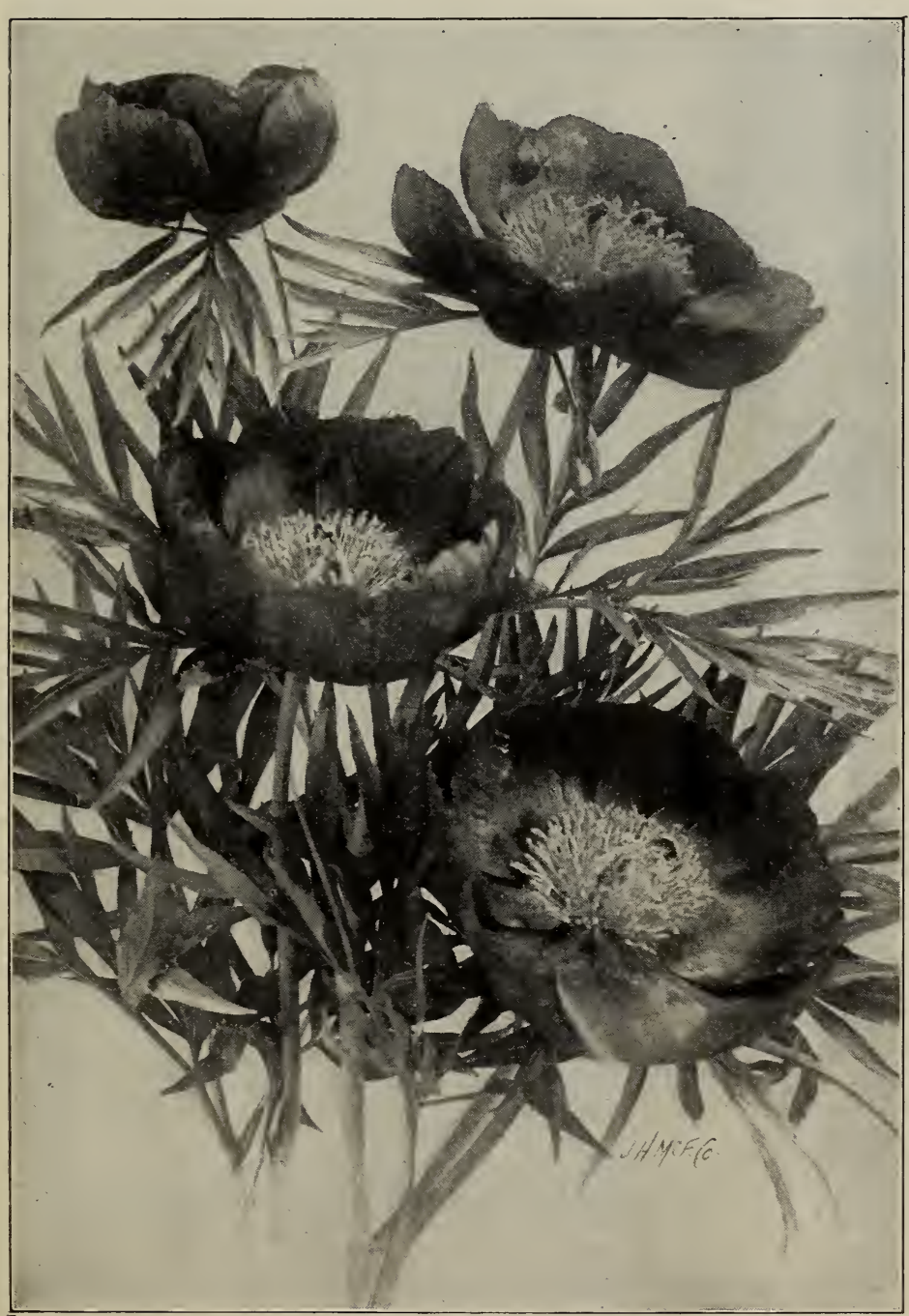

Peony Tenuifolia
$100 \quad 1000$

75

$75 \quad 800$

$50 \quad 500$

$\begin{array}{lll}00 & 10 & 00\end{array}$

$30 \quad 300$

75800 B. S....
CHOICE NAMED PEONIES, continued

Van Dyck. Fresh salmon-rose, with lighter center; Each Per doz. large convex flower. Very striking..............so 50

Victoria Modeste. Large flowers of violet-rose, center petals marked with large salmon lines.

Victoire de l'Alma. Large flower of perfect form, purplish violet-searlet; silvery reflex; cxtra.

$75 \quad 800$

$40 \quad 400$

Victoire Leman. Fresh pink collar, sulphur center, bordered carmine; very pretty flower

Victor Hugo. Very large; brilliant carmine-red; extra.

Virginie. Large flower, pink, tinted lilac; very fresh coloring; late

Whitleyi. White; large and sweet

\section{Kelway Peonies}

Kelway \& Son are the most famous of the English Peony-growers. The following is a selection of their best varieties:

Agnes Mary Keiway. Light rose guard petals, yellow peta-

loids, with a rose tuft; extra fine. First-class certificate, R. Each

so 75

Arimus. Purple-crimson, showing golden anthers............ 75

Baroness Schroeder. Lovely flesh-pink. First-class certificate,

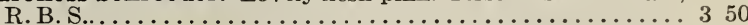

Cyclops. Purple-crimson. First-class certificate, R. B. S.

Cavalleria Rusticana. Very full, dark purplecrimson. First-class certificate, R. B. S.

Duke of Cambridge. A very handsome bright crimson flower; a superb variety; the very best of its color. $\$ 8$ per doz..

Helena. White, inner petals tipped yellow. First-class certificate, R. B. S.

Duke of Devonshire. "A large variety of deep rose color, with large outer guard petals and dense center."-Journal of Horticulture. "Duke of Devonshire is a fine large double variety, with deep rose guard petals and a mass of small inner petals of the same color."-Gardeners' Magazine. Award of Merit, R. H. S...

Ilion. White guard petals and white narrow center petals.

Limosel. Very bright, clear light lilac-rose very large flower; full double, with a broad guard petal and narrower petals in the center; sweet-scented. Certificate of merit, R. B. S., 1897

Lord Roseberry. Crimson; very fine.

Lottie Collins. Deep purple; early-flowering. Award of merit, R. H. S..

Lyde. Rose-color center, tinted pink; distinct and extra fine. First-class certificate, R. H. S. 100

Miss Brice. Rose guard petals, yellow and rose petaloids, rose tuft. First-class certificate, R. H. S. .

Miss Salway. White guard petals, sulphur center; very fine. First-class certificate, R. H. S. and certificate of merit, R. B. S.

Moonlight. Large white, tufted in the center. Award of merit, R. H. S.

Mr. Manning. Deep glowing crimson. Certificate of merit, R. B. S..

olivia. A lovely flower with broad white guard petals and a sulphur-colored center.

Prince George. Fine purple. First-class certificate, R. B. S..

Prince of Wales. Soft lilac-rose; very large flower. First-class certificate, R. B. S............ 150

Princess Irene. Pink guard petals, yellow petaloids.............................

Summer Day. Creamy white. Certificate of merit, R. B. S.

Sir T. J. Lipton. Large flower, with golden stamens appearing in the center of bright rosy crimson petals. "A huge double, bright rosy carmine flower of great merit." -Gardening World. Certificate of merit, R. B. S., 1897.

\section{Peony Clumps}

We can supply large undivided clumps of many varieties of Peonies. Typewritten price-list of these will be sent on request. 


\section{German Iris}

In the Iris family the German varieties rank second in importance, the magnificent Japanese Iris being first, of course. They bloom profusely early in May, are of the greatest hardiness and easiest culture, and should be freely planted in every garden. These Irises are the "Flags" of the oldfashioned gardens. They are most effective when used as edging for a shrubbery or garden border. There are no pure white varieties.

Named varieties. 15 cts. each, $\$ 1.25$ per doz., $\$ 8$ per 100 , unless otherwise noted.

Mixed Varieties. 10 cts. each, 75 cts. per doz., $\$ 5$ per 100 .

Canary Bird. Pale yellow; lovely.

Florentina Alba. Silvery white; early.

Honorable. Yellow; falls brownish maroon.

Madam Chereau. Pearly white, daintily edged with lavender.

Viscount de Brabant. Falls dark purple; standards light purple.

Dalmatica. Delicate lavender. Tall, vigorous plant with very large flowers; one of the finest of all Irises. 25 cts. each, $\$ 2.50$ per doz.

Parkmani. Falls purple and white; standards pale yellow.

Fragrans. Lovely white, edged with violet.

Dalmatica "Khedive." Pale blue. 25 cts. each, $\$ 2.50$ per doz.

Queen of the Gypsies. Standards bronze; falls light purple.

Donna Maria. White, tinged lilac.

Charlotte Patti. Standards lemon-yellow; falls same, veined reddisb. brown; dwarf.

Gracchus. Crimson, reticulated white.

Her Majesty. Lovely rose-pink. A variety of great distinction and beauty. 25 cts. each.

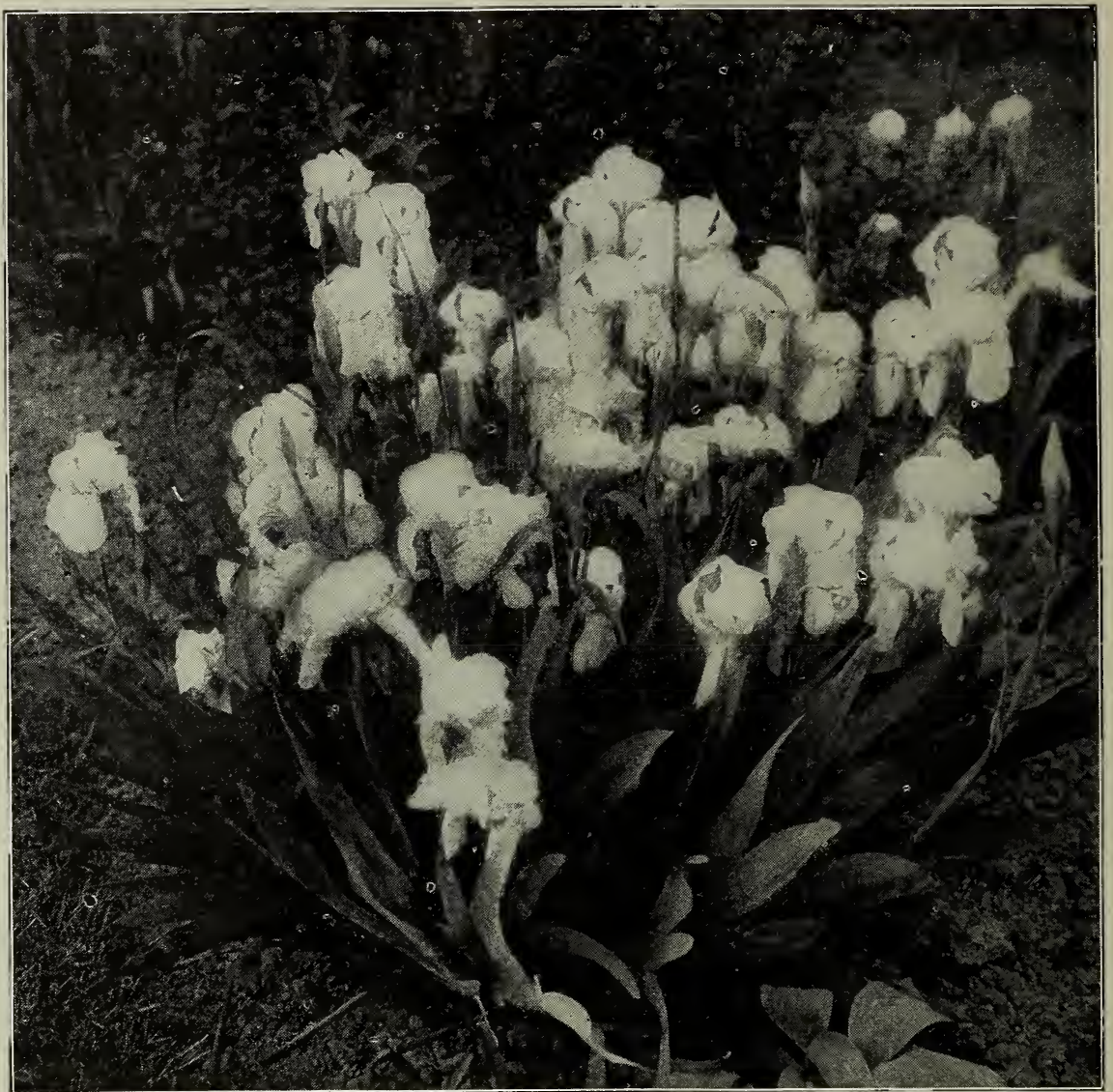

German Iris

Oroyo. Standards purple; falls purple, penciled white and mauve. Darius. Large; yellow and lilac.

Hamlet. Standards light bronze; falls dark maroon, reticulated white.

Queen of May. Lovely rose-lilac.

Agnes. Standards white; falls purple, edged white.

Gluck. Standards white; falls purple.

\section{Japanese Iris}

Some years ago a set of Japanese Iris (I. Kampferi) were sent to us from Japan to test, which were said to be identical with the collection in the Royal Gardens. We cannot vouch for this statement, as we have never been in Japan, but we have never seen another collection in America or Europe that would equal it in any way. The collection contained many colors and varieties we had never seen before, and the flowers were of remarkable size and beauty. When these Irises were in bloom they excited the greatest admiration and enthusiasm, and it was hard to convince people that these unique and exquisitely beautiful flowers were as hardy as apple trees, and as easily grown as potatoes. They will thrive in any good garden soil, but if the soil is made very rich and deep, and flooded with water for a month before and during their blooming season, they will produce flowers of a wonderful size, sometimes 10 to 12 inches across. These Irises should be planted in full exposure to the sun. As the Japanese names are unintelligible and impossible to remember, we have renamed this collection.

Since the above collection was received we have annually added to it the newest varieties from Japan and new varieties selected from thousands of seedlings grown on our own grounds, until we now have what is unquestionably the finest and most complete collection of Japanese Iris in the world.

\section{PRICES OF JAPANESE IRIS}

Named varieties, described in the following list, 25 cts. each, $\$ 2.50$ per doz., $\$ 15$ per 100 , except where noted. American-grown, fine mixed, without names, $\$ 1.25$ per doz., $\$ 6$ per 100, $\$ 50$ per 1,000

Alice Kiernan. Single. White, suffused with pale blue; center white, edged blue; extra large and fine; loveliest variety in cultivation. 50 cts. each, $\$ 5$ per doz.

Allegheny. Double. Pale lavender, striped white; late. $50 \mathrm{cts}$

Amoret. Double. Blue, blotched and mottled with dark blue and reddish plum, yellow bar at base; late. 


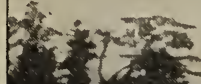

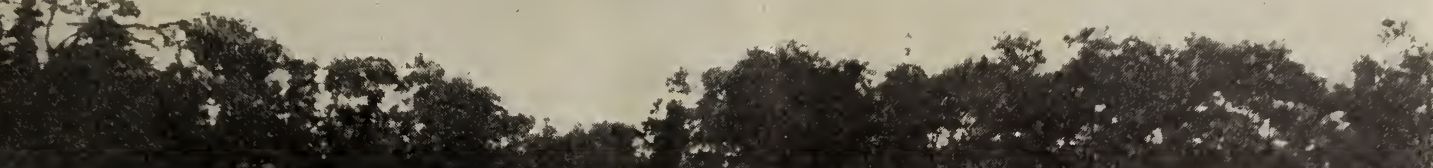

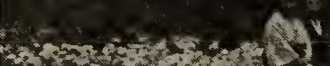

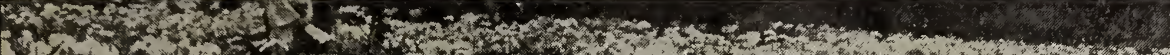

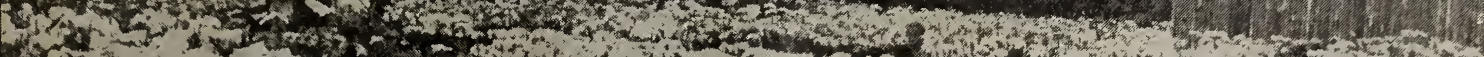

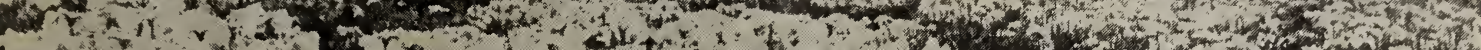

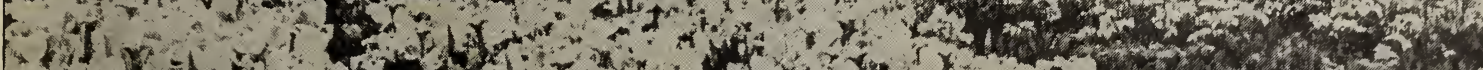

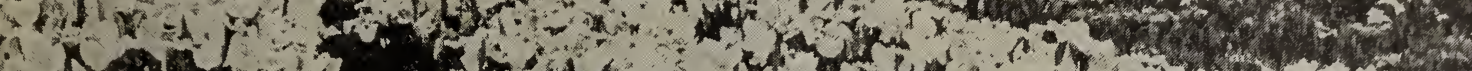

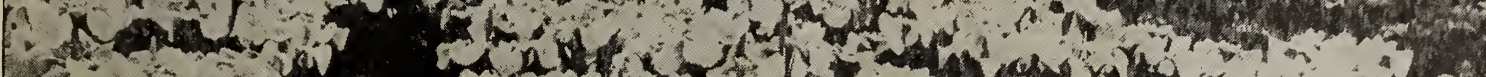

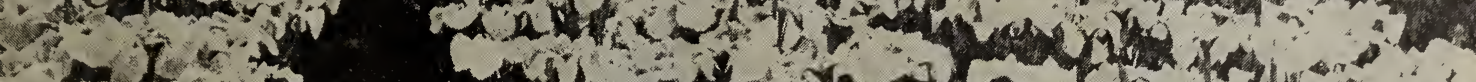

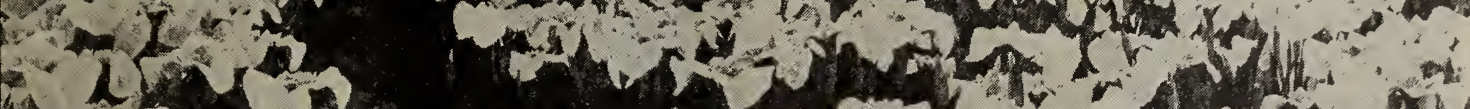

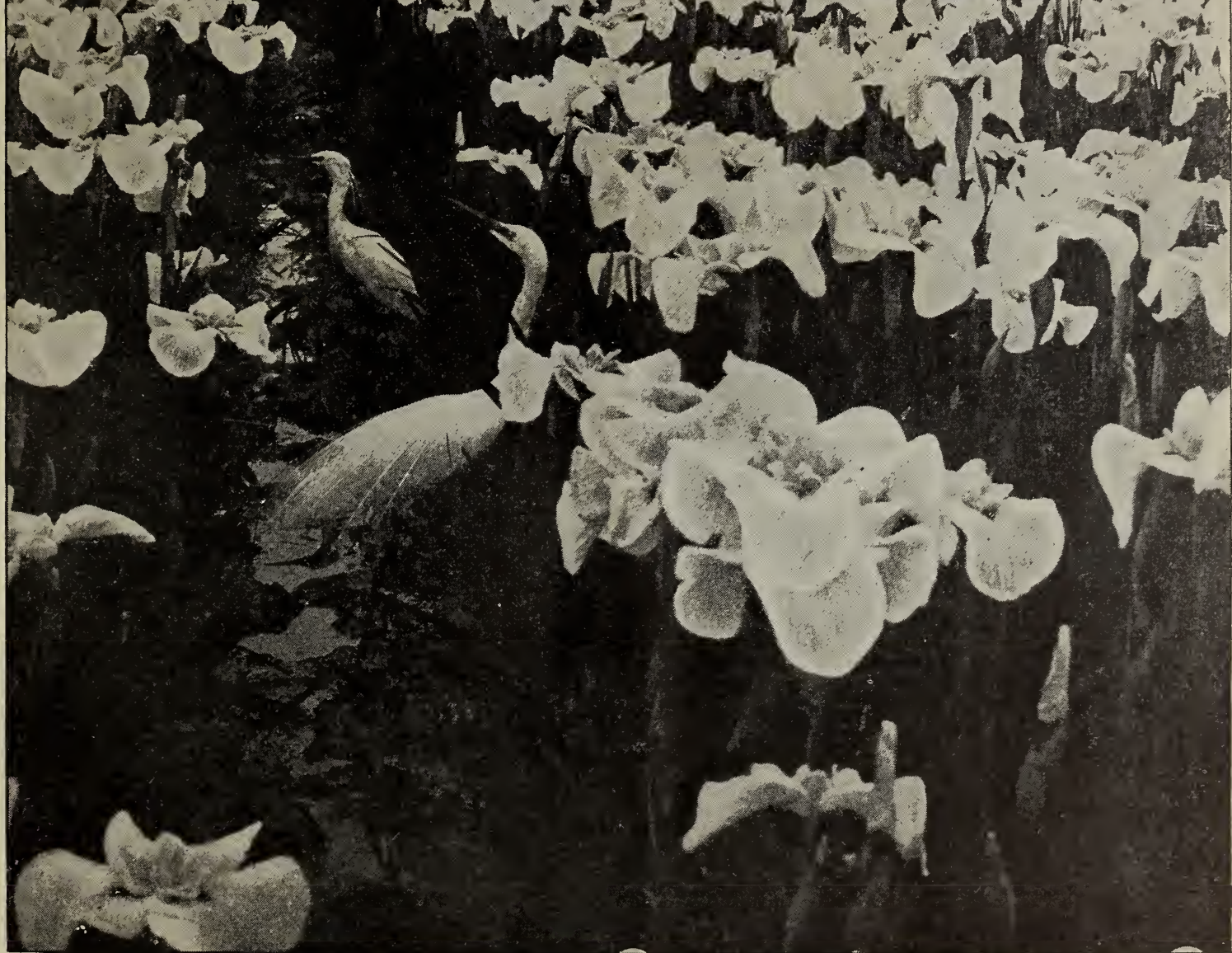

THE JUNE GLORY OF THE JAPANESE IRIS IN JAPAN (From The Country Calendar)

All the varieties of this beautiful Iris succeed in American gardens 


\section{JAPANESE IRIS, continued}

Angelo. Double. Bluish purple; center of petals white, with yellow band at base.

Apollyon. Double. Reddish plum, striped white; base of petals yellow; large and fine.

Aurora. Single. White, freely striped and suffused with magenta.

Blue Flag. Double; indigo-blue; base of petals yellow; the last variety to bloom. 75 cts. per doz., $\$ 5$ per $100, \$ 40$ per 1,000 .

Captain Brown. (New). Double. Petals blue and rose, with white edge; yellow bar at base; distinct and fine. $\$ 1$.

Cœrulea. Double. Lavender-blue, delicate coloring; large and distinct. 50 cts. each, $\$ 5$ per doz.

Edward A. Woods. (New). Single. Dark maroon, shading to white at margin of petals; extra-large and distinct. $\$ 1$.

Enchantress. Single. Pale blue, penciled with dark blue.

Esmeralda. Single. Magenta, penciled white, center white.

Fairy Queen. Single. White; base of petals yellow; maroon center. 50 cts. each, $\$ 5$ per doz.

Gigantea. Double. Bluish purple, lightly striped white; vigorous grower and free bloomer. The earliest-flowering variety in the collection. $\$ 10$ per 100 .

Glow. Double. Velvety maroon; large.

Heart of Gold. Double. Extra-large white flowers; yellow center.

Hermione. Single. White; maroon center; petals penciled with blue.

Ida. Reddish plum; rich and velvety; narrow yellow band on base of petals.

James R. Mellon. Double. Extra-large flower; lilac-striped with purplish blue, purple center; distinct and fine.

John Marron. Double. White, distinctly penciled with blue; blue center; base of petals yellow; late.

J. C. Slack. Double. Lilac, heavily blotched with magenta and blue; yellow center; distinct.

James F. Parker. Double. Rich dark blue; yellow center; large and fine. $35 \mathrm{cts}$.
Kitty. Single. Slightly suffused with pale blue. $50 \mathrm{cts}$.

Lorna Doone. Double. White, delicately penciled with blue; yellow band at base of petals; blue center.

Mrs. Morris Brandon. (New.) Double. White, penciled deep blue; center dark purple; late and fine. $\$ 1$.

Mrs. W. R. Massie. (New.) Single. Light maroon, blotched white; lovely. $\$ 1$.

Mrs. J. H. Ballantine. Single. Extra-large white flower, delicately suffused with pale blue; margins of petals pure white; fine. $50 \mathrm{cts}$.

Mont Blanc. Double. Pure white; large and fine. One of the finest of the white varieties.

Moonlight. Double. White flower, with yellow center. Rich and dainty in effect.

Octavia. Single. White; dark center; petals distinctly netted with blue.

Queen of the Whites. Double. White; vigorous grower.

Romola. Single. Lilac, striped with plum, plum center.

Rosalind. Double. Light purple, freely striped with white.

Snowårift. Single. Pure white.

Springdale. Single. Bluish purple, slightly striped white.

W. H. Buttfield. Double. Center of petals white, heavily margined with magenta; vigorous grower. $\$ 10$ per 100 .

Wm. J. Matheson. Double. Reddish plum; base of petals yellow; large and fine.

Wm. A. Procter. Double. Dark blue, slightly striped with white; yellow center.

Wm. Falconer. Double. Rich royal purple; extra fine. 50 cts. each, \$5 per doz.

Westmoreland. Double. Light blue, striped and suffused with darker blue.

Yokohama. Double. Reddish purple; base of petals yellow; large and fine. Late.

\section{New Irises}

\section{Siberian Irises}

Sibirica, Queen Victoria. Stiff, upright foliage, with flower-stems fully 4 feet high. Lovely white flowers, the largest of this section. 15 cts. each, $\$ 1.50$ per doz.

Sibirica, Snow Queen. An exquisite new hardy Iris; the flowers of a snowy whiteness, large and well-formed, produced in great abundance; foliage light and graceful. A gem for flower border or waterside. 3 feet high. Award of Merit, R. H. S., June 24, 1902. 15 cts. each, $\$ 1.50$ per doz.

Sibirica superba. Large violet-blue flowers; handsome foliage. Fine border plant and a grand subject for planting near water. 10 cts. each, $\$ 1$ per doz.

\section{German Irises}

Stylosa Innocens. Exquisitely beautiful white flowers, tinted with blue and yellow; almost pure white; a color never before obtainable in German Irises. 20 cts. each, $\$ 2$ per doz.

Aurea. A pure, rich, deep yellow; very distinct and fine. $15 \mathrm{cts}$. each, $\$ 1.50$ per doz.

\section{Dwarf Bearded Irises}

These Irises have flowers similar to the German Iris, but are much dwarfer and bloom in April. They are extremely free-flowering and desirable. $15 \mathrm{cts}$. each, $\$ 1.50$ per doz.

Socrates. Bright claret-red; falls deeper claret; beard yellow.

Orange Queen. Beautiful clear yellow, with orange beard.

\section{Native Irises}

Pseudo-acorus. Semi-aquatic variety; valuable for planting in swamps and on the edge of pouds; vigorous plant with lovely yellow flowers. 15 cts. each, $\$ 1.50$ per doz.

Pseudo-acorus variegata. Same as above with variegated foliage. 15 cts. each, $\$ 1.25$ per doz.

Versicolor. The common blue flag of our swamps and meadows; valuable for naturalizing. $10 \mathrm{cts}$. each, $\$ 1$ per doz., $\$ 6$ per 100 .

\section{Iris pumila}

These beautiful little Irises do not grow over 4 inches high, and bloom in April and May. We offer blue, indigo-blue, dark blue, deep yellow, and in mixed varieties. 10 cts. each, $\$ 1$ per doz., $\$ 6$ per 100 .

\section{Special Offer.}

Of some of the fine named Japanese Iris we have immense stocks, larger than we wish to carry, and, to reduce them, we are offering these varieties at prices very little higher than those of the common mixed varieties. Where the selection of varieties is left entirely to us, we will furnish fine plants and fine varieties at $\$ 9$ per 100 , $\$ 70$ per 1,000 and will furnish 500 at the 1,000 price. 


\section{Tall English Delphiniums}

We are tempted to say that the Improved English Delphiniums are the most beautiful hardy plants in cultivation, but we are also tempted to say this of a score of other things, and, of course, it is impossible to say which is the most beautiful of hardy plants, for they have such an immense varicty of beauty that the wonder grows that peoplc continue to plant, by the million, bedding plants which have little or no beauty, are an annual expense, and cost quite as much as hardy plants, whose first cost is their only cost, and which increase in size, in beauty, and often in quantity, year after year. These Delphiniums may not be the most beautiful hardy plants, but they are among the most beautiful, and nothing can be morc distinct and satisfactory. They are statcly and picturesque, some varicties growing cight feet high in rich soil; they have immense spikes of most beautiful flowers of every imaginable shade of blue, and their season is a long one; in fact, they will bloom from spring till fall if properly treated.

CULTURE OF DELPHINIUMS.-The culture of Delphiniums is exceedingly simple, and the results out of all proportion to the slight amount of care necessary. They thrive in almost any position, and may be planted at any time of the year, provided that in summer the plants are not too forward, and that they be wcll watered if the weather be dry. The soil may be a rich, friable loam, which suits them finely; but any soil, even hot and sandy, if well watered and manured will give excellent results. Dig deeply-trenching is better,-add plenty of well-rotted manure, and plant about $2 \frac{1}{2}$ feet apart. Placed in lines, as a background to a border, or in groups of, say, three plants at intervals, the effect of the Delphinium is exceedingly fine. They look well in beds, also, arranged at the same distance apart each way. They are grand grown in masses of large groups of separate colors, and may be associated with shrubs with great advantage, succeeding well in shrubberies because of their robustness. A succession of flowers may be expected from spring to early autumn, especially if the spikes which have done flowering early be cut down to the ground; fresh growth will then be produced which will give blossom. Copious watcring in summer will be attended by increased size of spike and flower; in fact, in seasons of prolonged drought, water is absolutely a necessity on many soils if the varieties are to exhibit themselves in their true size and beauty of flower and spike. Top-dressing is greatly recommended on certain soils, instead of the bare surface of the ground being left exposed to the sun. Some of the neater dwarf alpine and other hardy plants may be utilized to plant between and around Delphiniums. Coal ashes strewn over the crowns will protect the plants from slugs through winter and spring. As we have intimated, any garden soil suits the Delphiniums; it is, however, necessary to secure sorts such as are offered below in order to obtain an effect superior to that afforded by the old smaller-flowered varieties. No amount of liberal treatment will cause the smaller-flowered kinds of a few years back to develop into the gorgeous hybrids of today.

\section{SPECIAL OFFER OF IMPROVED ENGLISH DELPHINIUMS}

I want every one who receives this price-list to try these improved English Delphiniums, and to that end offer them at extremely low prices. I guarantee that they will give unqualified satisfaction in every instance and will be a revelation of beauty to most people.

Fine Mixed English, grown from seed of Kelway's Per doz. 100

famous named sorts.................... $51 \quad 50 \quad \$ 10 \quad 00$

English, in separate colors, grown from Kclway's newest named sorts. . .

\section{$200 \quad 1300$}

Selected Varieties, selected from thousands of seed-

lings grown from Kelway's choicest named sorts... 300

Extra Selected Varieties...........each, $50 \mathrm{cts...5} 00$

2000

Winter Varieties. Not recommended.... each, $\$ 1 . .$.

\section{Delphinium formosum}

In the perennial Delphiniums, or Larkspurs, we have one of the most beautiful and useful families in hardy plants. The old $\mathrm{Del}$ phinium formosum is one of the few hardy plants which have been pretty generally offered by the plant trade, yet is comparatively unknown, although few things can be planted that will give more satisfaction, whether the object is decorative effect in the garden or flowers for cutting for the house. Messers J. H. Small \& Sons, the leading florists of New York and Washington, have made quite a hit with it as a novelty in cut-flowers. The flowers are intense deep blue, perhaps the most brilliant blue to be found in flowers freely produced in long spikes. It blooms in June and July and continues for a long time in bloom, and if the plants are cut back after flowering will bloom a second time in the fall. Plants grow to 4 or 5 feet high, and, if planted in masses about 2 feet apart, will produce a splendid effect. $15 \mathrm{cts}$. each, $\$ 1.25$ per doz., $\$ 8$ per 100 .

\section{Delphinium formosum cœlestinum}

This rare and scarce Delphinium has all the good qualities of the well-known Formosum, but instead of dark blue flowers produces great spikes of exquisite light blue bloom, the loveliest shade of blue in the floral world. We have always treasured this Delphinium in our garden, but could never get enough stock of it to offer. This season we have secured a few thousand plants, which we can offer at a reasonable price. 15 cts. each, $\$ 1.50$ per doz., $\$ 8$ per 100 ,

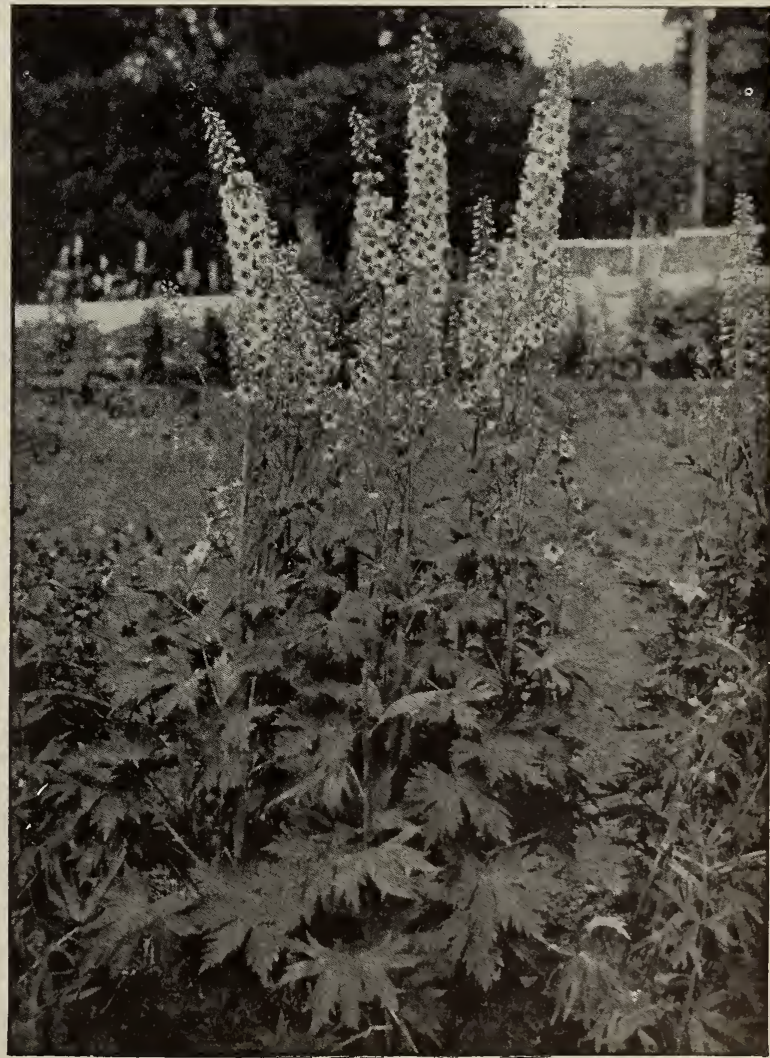

Specimen plant of Improved English Delphiniums 


\section{Hardy Perennial Phloxes}

The beauty and usefulness of these grand border plants give to them a deservedly first place among hardy plants. For cutting, their large trusses go a long way in floral decoration. In color they range from pure white to the richest crimsons and purple, and from soft rose and salmon to bright coral-red, all having a delicate fragrance. Perennial Phloxes succeed in almost any soil enriched with manure, but are much benefited by a mulching of decomposed manure in the spring, and in hot weather an occasional soaking of water. If the first spikes of bloom are removed as soon as over and the plant given a good soaking of water, they will produce a second supply of flowers, thus continuing the display until late in autumn. These later blooms are often finer than the first.

The following list includes a selection made by us in France, Germany, Holland, and England during the last summer, as well as all of the very best of the new and old varieties.

We grow upward of a hundred thousand Phloxes annually, and when these are in bloom, they are well worth coming to see.

Field-grown plants, 15 cts. each, $\$ 1.50$ per doz., $\$ 10$ per 100. Late orders will be filled with pot-grown plants after it is too late to transplant from the field.

A. G. McKimmon. Early-flowering; purplish lilac; large truss. Adonis. China-rose; large carmine eye.

Albion. Strong, vigorous grower; large panicles of pure white flowers with faint red eye.

Astier Rheu. Deep purplish crimson.

Beranger. Rosy white, suffused gray; very delicate shade; lovely.

Boule de Feu. Bright rosy red, dark center.

Champs Elysees. Fine rich purplish crimson.

B. Compte. Glowing red; a vigorous, free variety.

Bacchante. Crimson, with carmine eye; dwarf and very bushy; full-flowering.

Bouquet Fleur. White, pink center.

Comet. Rich dark crimson; the richest colored of all Phloxes.

Duqueslin. Deep rose, edged lilac.

Eclaireur. Bright purplish rose; light center; enormous flowers.

Edmond Rostand. Reddish violet, shading brighter toward the center of petals; large, white star-shaped center.

Forerunner. Early-flowering; white, suffused with rosy purple.

Ferdinand Cortez. Bronzy copper; distinct and fine.
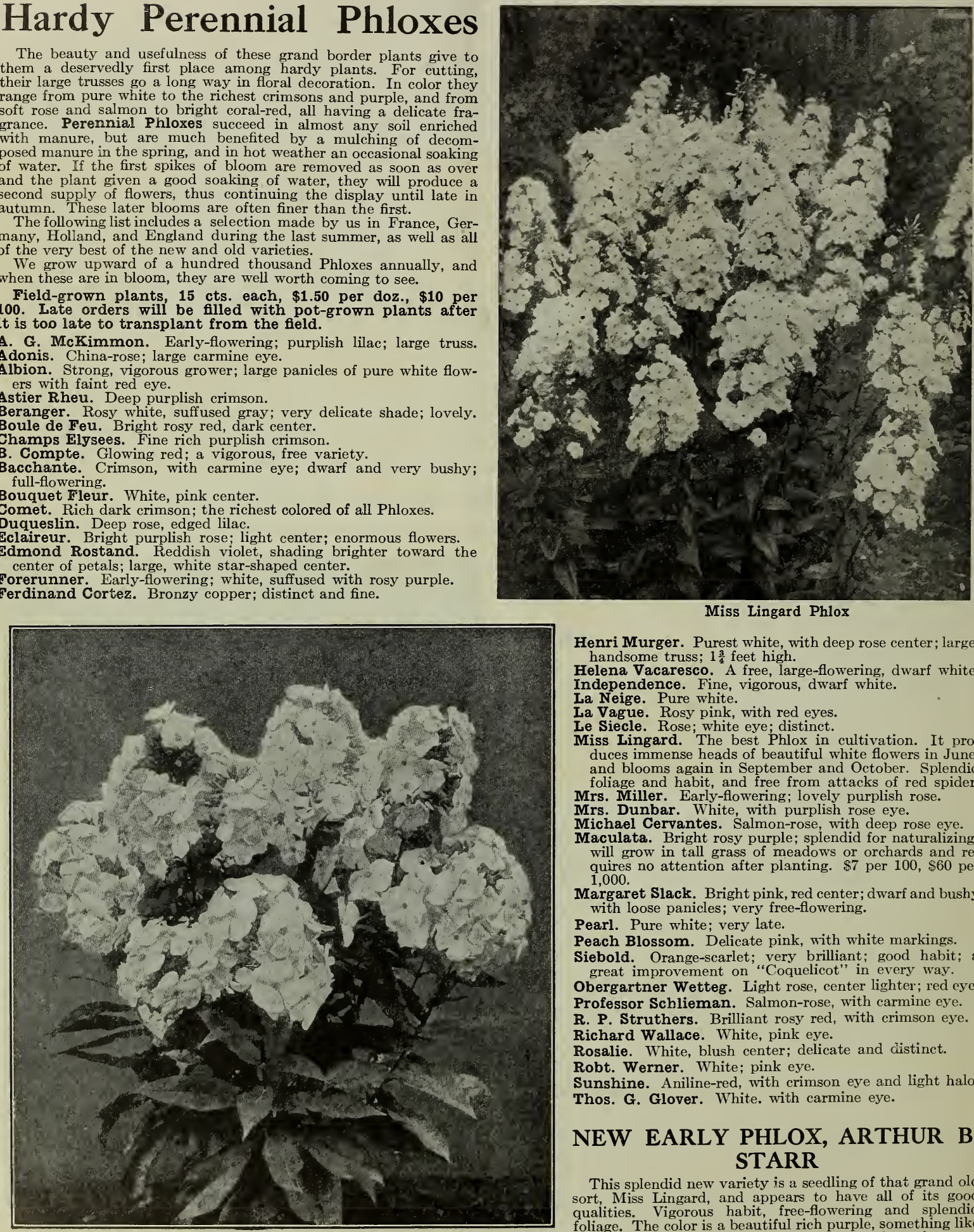

Miss Lingard Phlox

Henri Murger. Purest white, with deep rose center; large, handsome truss; $1 \frac{3}{4}$ feet high.

Helena Vacaresco. A free, large-flowering, dwarf white. Independence. Fine, vigorous, dwarf white.

La Neige. Pure white.

La Vague. Rosy pink, with red eyes.

Le Siecle. Rose; white eye; distinct.

Miss Lingard. The best Phlox in cultivation. It produces immense heads of beautiful white flowers in June, and blooms again in September and October. Splendid foliage and habit, and free from attacks of red spider.

Mrs. Miller. Early-flowering; lovely purplish rose.

Mrs. Dunbar. White, with purplish rose eye.

Michael Cervantes. Salmon-rose, with deep rose eye.

Maculata. Bright rosy purple; splendid for naturalizing; will grow in tall grass of meadows or orchards and requires no attention after planting. $\$ 7$ per $100, \$ 60$ per 1,000 .

Margaret Slack. Bright pink, red center; dwarf and bushy with loose panicles; very free-flowering.

Pearl. Pure white; very late.

Peach Blossom. Delicate pink, with white markings.

Siebold. Orange-scarlet; very brilliant; good habit; a great improvement on "Coquelicot" in every way.

Obergartner Wetteg. Light rose, center lighter; red eye.

Professor Schlieman. Salmon-rose, with carmine eye.

R. P. Struthers. Brilliant rosy red, with crimson eye.

Richard Wallace. White, pink eye.

Rosalie. White, blush center; delicate and distinct.

Robt. Werner. White; pink eye.

Sunshine. Aniline-red, with crimson eye and light halo. Thos. G. Glover. White. with carmine eye.

\section{NEW EARLY PHLOX, ARTHUR B. STARR}

This splendid new variety is a seedling of that grand old sort, Miss Lingard, and appears to have all of its good qualities. Vigorous habit, free-flowering and splendid foliage. The color is a beautiful rich purple, something like Perennial Phlox the late variety Le Mahdi. $25 \mathrm{cts}$. each, $\$ 2.50$ per doz. 


\section{Plants Suitable for Naturalizing}

The most delightful and least troublesorne form of gardening is the planting of suitable hardy plants and bulbs in the rougher parts of the grounds and allowing them to take care of themselves exactly the same as the wild flowers. Many plants are perfectly at home in the grass; of course we do not mean the grass of a lawn which must be mown, but the grass of meadows and orchards, along streanis and ponds and on the edges of woods and wild shrubbery. We give a few suitable varieties below, but there are scores of others, and we shall be glad to send a list of these when desired.

BELLIS perennis (Double English Daisy). There is nothing more charming for naturalizing than this popular little flower endeared to thousands by Robert Burns' delightful poem. It can even be grown on the lawn, as it accommodates itself to the lawn-mower. White and pink varieties. 50 cts. per doz., $\$ 3.50$ per 100 .

ASTER Novæ-Angliæ rubra. Everybody knows the wild Asters which make such beautiful pictures along the roadsides in the fall, but this splendid largeflowered variety does not grow wild throughout the country. Either for naturalizing, for the garden, or for planting among shrubbery, there is no finer fallflowering plant. $\$ 1.50$ per doz., $\$ 8$ per 100 .

A QUILEGIA Canadensis. This beautiful native Columbine grows wild in many parts of the country. There is no finer subject for naturalizing. It is perfectly at home on a rocky bank or in the grass. $\$ 1.50$ per doz., $\$ 10$ per 100 .

Cœrulea (True). This charming blue and white Columbine is one of the loveliest of garden plants and just as desirable for naturalizing. $\$ 1.75$ per doz., $\$ 12$ per 100 .

Chrysantha. A bright yellow Columbine that is in bloom for two months. Used with $A$. cœrulea, blue, and A. Canadensis, red, a most charming picture can he made. $\$ 1.50$ per doz., $\$ 8$ per 100.

HARDY ENGLISH PRIMROSE. One of the loveliest sights in all England are the hardy primroses in bloom in orchard and meadows in early spring. In many places the ground is carpeted with their lovely canary-yellow flowers, which are delightfully fragrant. They are equally hardy here, and nothing can be more delightful, either for naturalizing in orchard, meadow, along a brook, or planting in borders or along the edge of a shrubbery border. 10 cts. each, $\$ 1$ per doz., $\$ 5$ per 100.

CORONILLA varia. One of the prettiest floral pictures we have ever seen was a great mass of this in one of the meadows of Franklin Park, Boston. It completely covered the ground and had piled itself up in a pleasing tangled mass of green foliage and white and pink bloom. $\$ 1.25$ per doz.

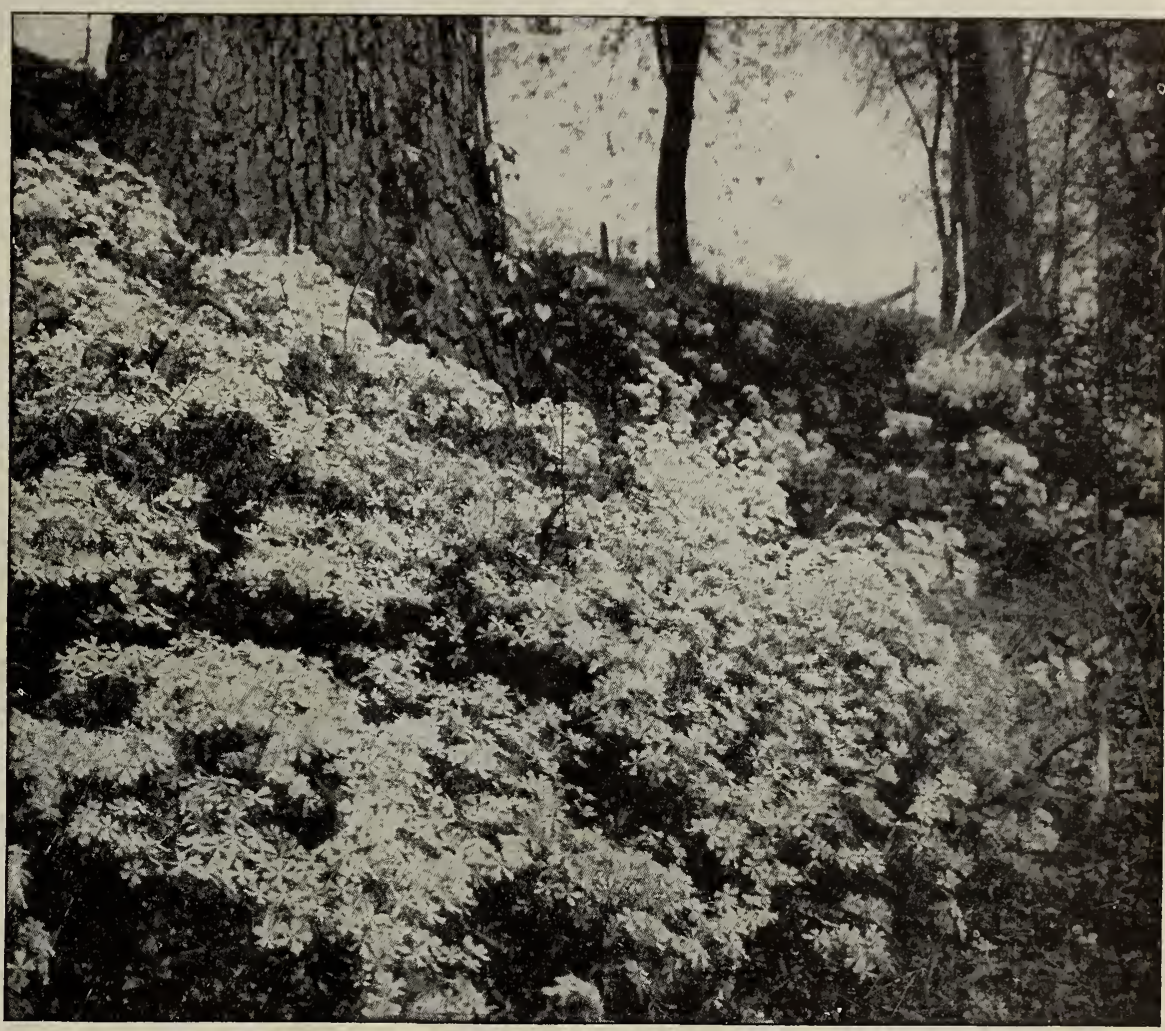

Phlox divaricata Canadensis, naturalized

HELIANTHUS, or HARDY SUNFLOWERS. All varieties of hardy Sunflowers are fine for naturalizing, and where the selection of varieties is left to us we will furnish them at the following low prices. $\$ 1$ per doz., $\$ 6$ per $100, \$ 50$ per 1,000 .

\section{Phlox divaricata Canadensis}

One of our native varieties that is but rarely met with, and which has been introduced into Europe the past few years as a novelty. A plant that is certain to meet with much favor when better known, as nothing can produce such a cheerful corner in the garden in very early spring. Frequently beginning to bloom early in April, it continues until about the middle of June, with large, bright lilac-colored flowers, which are produced on stems about 10 inches high, in large, showy heads, and are very fragrant. Extremely fine for naturalizing in the woods and shady places. Although this Phlox is usually found growing wild in shady places, it will do better if it is planted where it has full exposure to the sun and will bloom more freely. $10 \mathrm{cts}$. each, $\$ 1$ per doz., $\$ 6$ per 100 .

\section{Other Choice Hardy Perennial Flowers Suitable for Naturalizing}

Butterfly-weed (Asclepias). Orange or yellow day-lilies (Hemerocallis).

Sweet rocket (Hesperis).
Anemone Pennsylvanica.

Japanese anemones, white.

Iris versicolor.
Iris Sibirica, var. sanguinea.

Lythrim roseum.

Giant knot-weed.
Forget-me-not (Myosotis)

Phlox (maculata).

Goat's beard (Spirapa aruncus) 


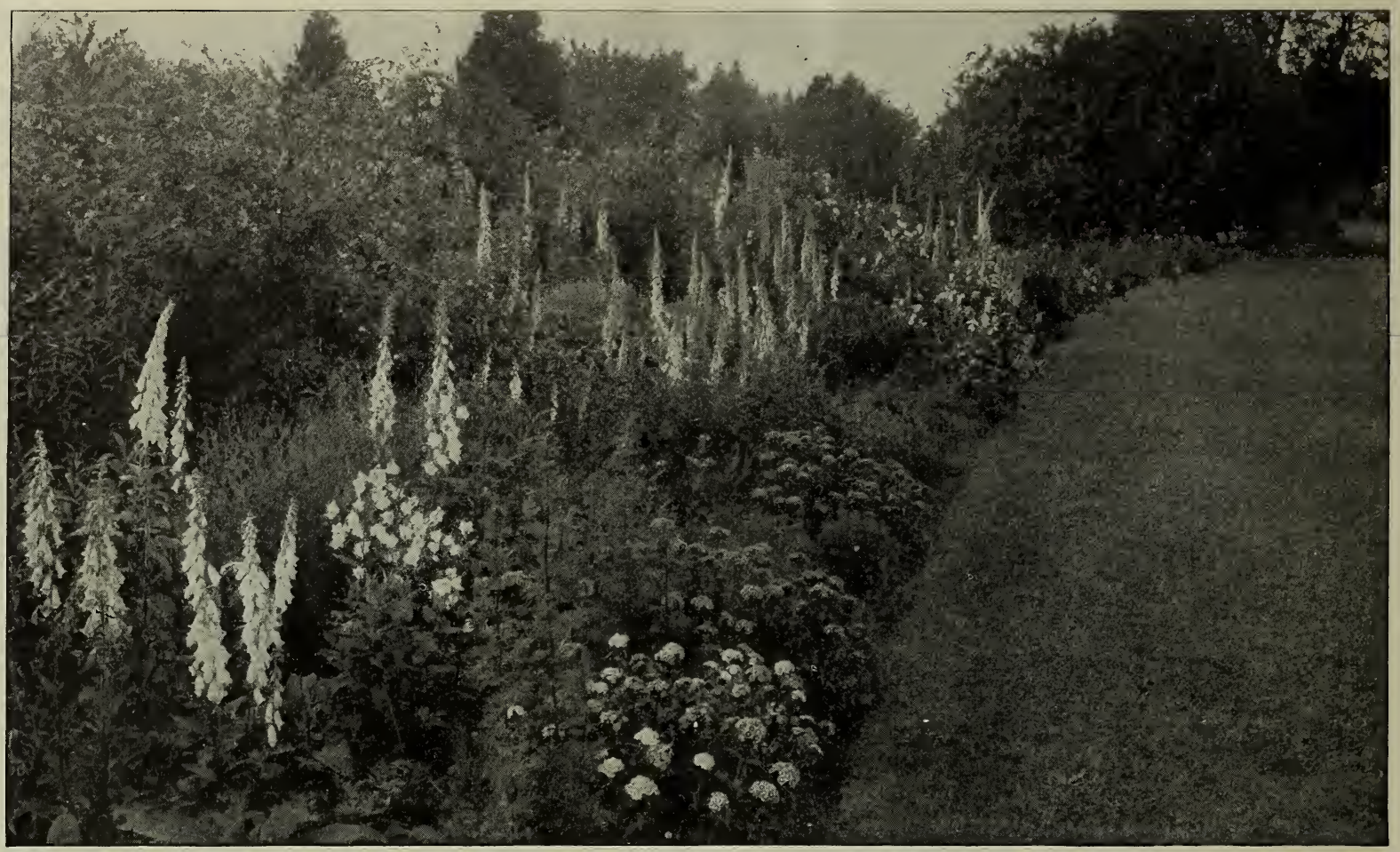

Border of Hardy Plants

\section{Some Notable Hardy Plants}

Elsewhere will be found a very complete list of hardy plants, but the following varieties are especially desirable, and I am in a position to furnish them in quantity at very low prices.

\section{Aquilegias}

All of the single, long-spurred Aquilegias, or Columbines, are extremely beautiful, and a collection of them should be a feature in every garden. Foremost among these choice plants are our native Aquilegias. If these and other choice hardy plants were as well known as bedding plants, the day of geraniums, coleus, and other commonplace plants would soon be over. The flowers of these Aquilegias are most lovely and delicate, ranging from white to crimson, including shades of blue and yellow. The exquisite Rocky Mountain Columbine, Aquilegia cœrulea, is one of the loveliest flowers in cultivation, and it and Aquilegia Canadensis, which grows wild so plentifully in many localities, are both fine for naturalizing and will thrive if planted in the grass of meadows and allowed to take care of themselves. They are also fine for the formal garden. Assorted varieties, our selection, $15 \mathrm{cts}$. each, $\$ 1.25$ per doz., $\$ 8$ per 100 . For complete list of varieties, see general list of hardy plants.

\section{Armeria (Thrift)}

Attractive dwarf plants that will succeed in any soil, forming evergreen tufts of bright green foliage, from which innumerable flowers appear in dense heads, on stiff, wiry stems about 9 inches high. They flower more or less continuously from early spring until late in the fall. Very effective in the rockery and indispensable in the border. Fine for edging beds and borders on account of extremely dwarf habit of growth.

Formosa. Pink.

Cephalotes. Bright, rosy pink flowers.

Maritima splendens. Bright pink; fine.

15 ets. each, \$1.25 per doz., \$7 per 100

\section{Calimeris incisafolia}

A graceful little plant with finely cut foliage and the prettiest of all single white daisy-like flowers. Blooms all summer and is distinct and fine. 15 cts. each, $\$ 1.50$ per doz., $\$ 8$ per 100 .

\section{Stokesia cyanea}

\section{(The Cornflower, or Stokes' Aster)}

A most charming and beautiful native hardy plant, which for the past few seasons, has been the most admired flower on our grounds. The plant grows from 18 to 24 inches high, bearing freely, from early in July until late in October, its handsome lavender-blue centaurealike blossoms, which measure from 4 to 5 inches across. It is of the easiest culture, succeeding in any open sunny position, and not only is it desirable as a single plant in the hardy border, but it can also be used with fine effect in masses or beds of any size. 15 cts. each, $\$ 1.50$ per doz., $\$ 8$ per 100 .

\section{Malva moschata}

This lovely Mallow blooms profusely in June and July, and grows 18 to 24 inches high. The flowers are rose-colored; 2 inches across. 15 cts. each. $\$ 1.50$ per doz.

\section{Arenaria montana}

Forming fine mounds smothered with large snowy white flowers in early summer. A valuable rock-garden and border plant; grows 6 inches high. 20 cts. each, $\$ 2$ per doz. 

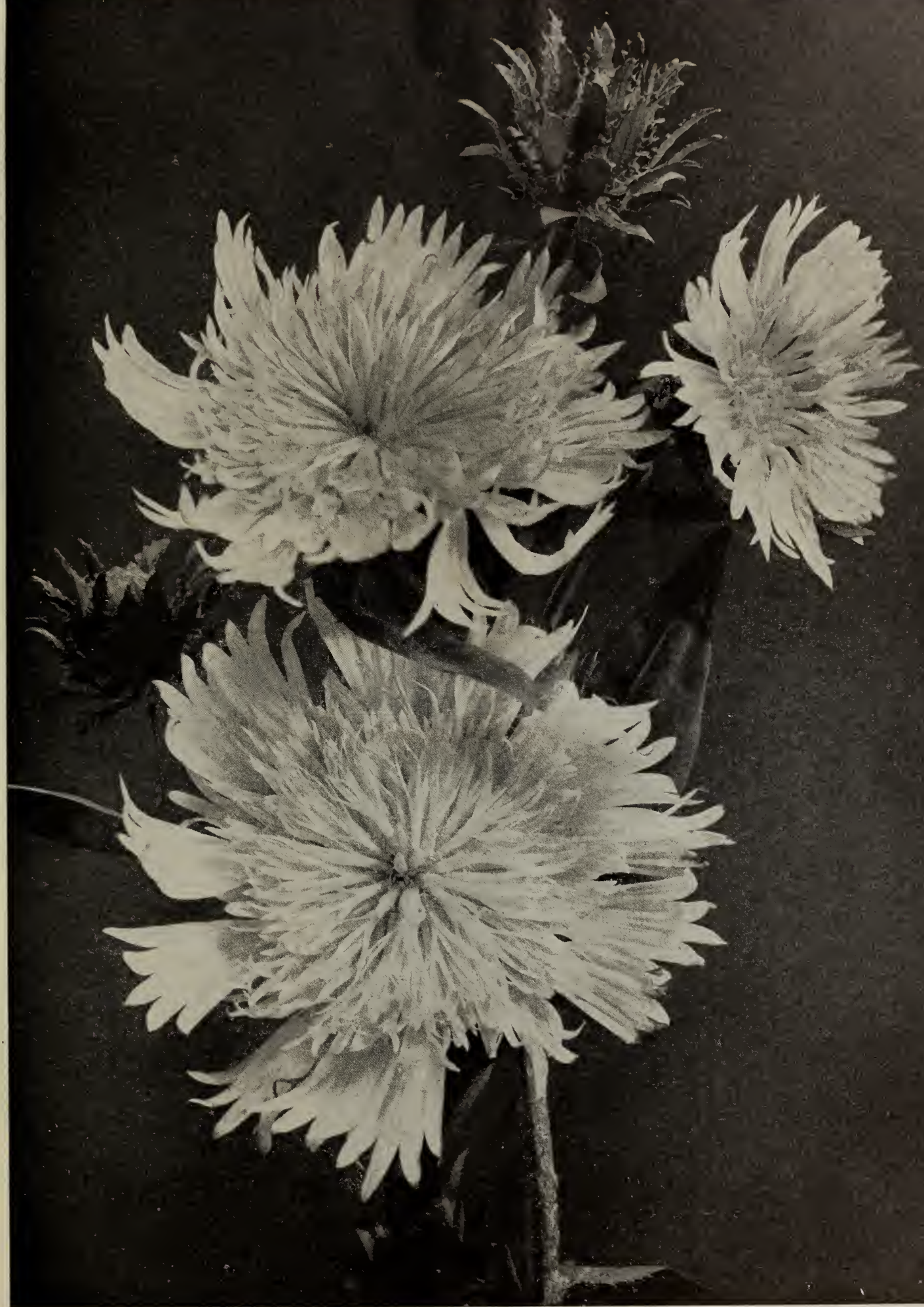


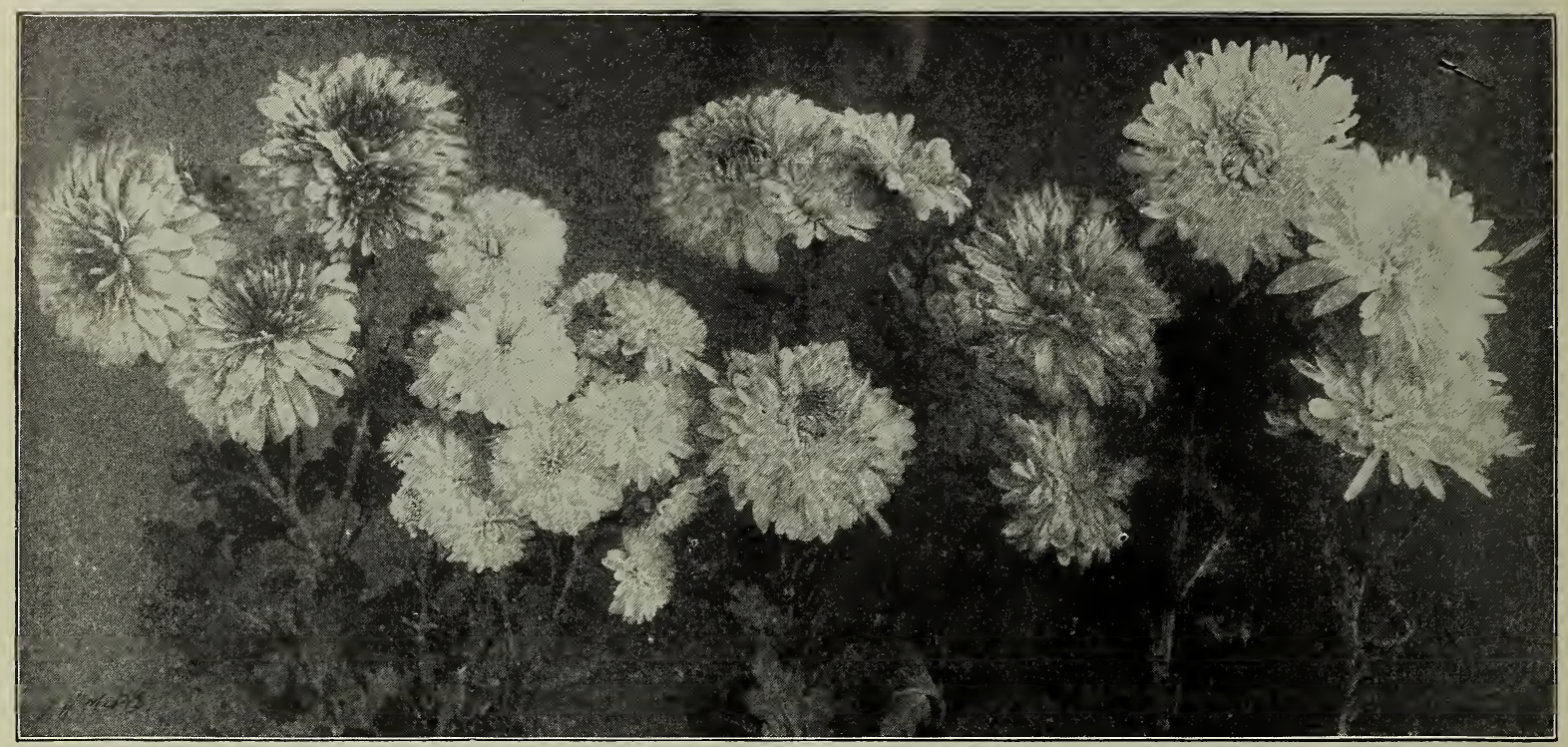

Pompone Chrysanthemums

\section{Polemonium reptans}

(Jacob's Ladder)

Useful border plants about 12 inches high, with deep green, finely cut foliage and spikes of showy blue flowers in May and June; of graceful growth. $15 \mathrm{cts}$. each, $\$ 1.50$ per doz.

\section{Spiraea filipendula}

A plant of decided merit, growing 2 to $2 \frac{1}{2}$ feet high, with fern-like foliage, with loose clusters of white flowers; blooms end of May. 15 cts. each, $\$ 1.50$ per doz.

\section{Phlox Carolina}

A very desirable native Phlox, growing about 12 inches high. Bright pink flowers in May and June. 15 cts. each, $\$ 1.50$ per doz.

\section{Blackberry Lily}

(Pardanthus Sinensis)

Lily-like flowers of a bright orange color spotted with red, which are succeeded by seeds that resemble blackberries. Very showy and desirable. $15 \mathrm{cts}$. each, $\$ 1.50$ per doz.

\section{Large-flowered Chrysanthemums}

We have collected from farm gardens some of the old-fashioned Chrysanthemums which are really hardy and which bloom in October and November, after all other outdoor flowers are gone. Often in bloom when the snow is on the ground; old, established beds are very showy. 3 to 4 feet high. When in bloom are a perfect mass of flowers. Our stock is grown in pots and can be delivered any time during the spring or summer. We offer four large-flowered varieties-White, Pink, Blush and Yellow. 15 ets. each, $\$ 1.50$ per doz., $\$ 10$ per 100 .

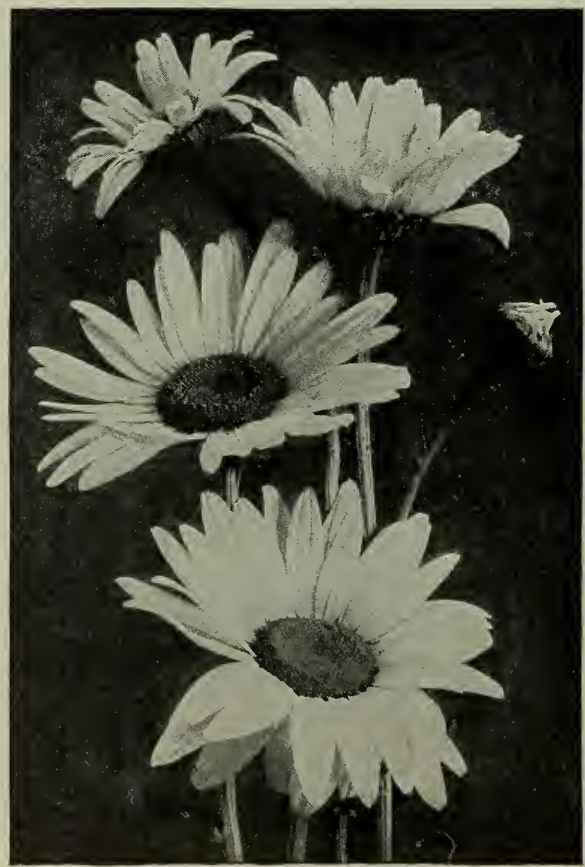

Chrysanthemum latifolium

\section{Chrysanthemum latifolium}

We have at last succeeded in getting a stock of the true variety of this most beautiful of all the Single Daisies. It is one of the most satisfactory hardy plants for the garden or border, and produces its large, beautiful single white flowers in the greatest profusion. It should be included in every collection of hardy plants. $15 \mathrm{c}$. each, $\$ 1.25$ per doz., $\$ 10$ per 100.

SHASTA DAISY. This new California Daisy has been introduced with a great hurrah, and may be all that is claimed for it, but, so far, in our garden, does not appear to be so good as Chrysanthemum latifolium, which it resembles. However, there is a large demand for it and it is our business to supply the demand. 15 cts. each, $\$ 1$ per doz.

PRINCESS HENRY. This has larger flowers than $C$. latifolium, and really is an improvement. $15 \mathrm{cts}$. each, $\$ 1.50$ per doz.

\section{Pompone Chryanthemums}

These are the small-flowered Chrysanthemums of the old-fashioned gardens, and bloom in October and November after almost all flowers are gone. They are showy in the garden and effective as cut-flowers, and, being perfectly hardy and of easiest culture, can be successfully grown in any garden. We offer a fine collection of the best varieties, ranging from white to deep crimson. 15 cts. each, $\$ 1.50$ per doz., \$8 per 100 Globe d'Or. Light yellow; extra.

Regulus. Bronze-yellow.

Wm. Westlake. Dark red, center yellow.

Triumph. Deep rose; large.

Blushing Bride. Light pink.

Julia. Dark crimson; large flowers of good form.

Flora. Bright yellow.

Trojan. Dark yellow, striped coppery red.

Golden Pheasant. Golden yellow. 
POMPONE CHRYSANTHEMUMS, continued

Elegante. Pink; center whitc.

s. Croats. Yellowish white; almost pure white when fully open. Deans. Pure white.

St. Illona. White tipped with pink.

Bob. Light pink; yellow center.

Tiber. Yellow and copper-red.

Fairy Queen. Blush shading to bronze.

Rosinante. Pale pink, center lighter.

Donizula. Blush.

Pink Beauty. Very small button-like pink flower.

Rubra minima. Very small button-like flowers; coppery red.

\section{Physostegia Virginica alba}

An American plant, and by no means a new one; yet it is a flower so unique in its make-up that it stands apart from all others and alone. For massing, planting in association with other appropriate varieties in the border, for planting with shrubbery or for cut-bloom, it is unrivaled. In value it is not equaled by the popular Golden Glow; and it possesses a constitution just as rugged. Its large, graceful spikes of white flowers are produced in greatest profusion from about the middle of June, and if kept cut (so as not to produce seed) it continues to flower in a perfect mass of bloom until frost. The flowers themselves are intensely interesting and attractive, resembling large heather. The stems are long, square, thick, rigid and strong, holding the flowers in a dignified and stately manner when upon the plant and when cut. The plants form large, dense clumps, 3 or 4 feet high, and require no petting, succeeding on all kinds of soil and in all situations. 15 cts. each, $\$ 1.25$ per doz., $\$ 8$ per 100 .

\section{Polyanthus, or Cowslip}

This charming spring-blooming plant belongs to the Primrose family, the hardy varieties of which are so very popular in England, but are rarely seen in this country, owing partly to an impression that they cannot be grown in this climate. This is a mistake, as they do very well here. For the front of borders and shrubbery, for spring bedding, and for naturalizing in moist and partly shaded places nothing can be finer. The coloring in the flowers is especially rich and fine. At this writing we have a long border of these plants in bloom in our garden, and nothing gives us greater pleasure. They are ss charming in habit, rich and varied in coloring, and so early to bloom, coming with the spring-flowering bulbs, that nothing can be more acceptable. We use them freely for decorating the dining-table and library windows, taking plants up from the border and putting them in fern-dishes and pots, where they go on blooming as if they had never been disturbed. Their hardiness has been pretty well settled by the severe winter of 1898 and 1899. The minimum temperature at our country place was 24 degrees below zero. Not a single Polyanthus was injured, and they were planted in wet soil at that. 15 cts. each, \$1 per doz., \$6 per 100.

Large-flowered White. An improved variety, with very large flowers; very fine. 20 cts. each, $\$ 1.00$ per doz., $\$ 6$ per 100 .

\section{Hardy Primroses}

The hardy Primroses do not receive the attention they deserve. They are charming little spring-flowering plants of the easiest culture, and thrive in partial shade. Very valuable for naturalizing and for edging beds and borders. They are among the modest things of earth which have a charm and loveliness all their own.

Primula Cashmeriana. A rare and beautiful Primrose with rich violet-purple flowers. $20 \mathrm{cts}$. each, $\$ 2$ per doz.

Primula Japonica. Showy; perfectly hardy; colors ranging from pure white to rich purplish crimson. 15 cts. each, $\$ 1.50$ per doz.

Primula Lorelei. A rare and exquisitely beautiful variety with large heads of purplish pink or white flowers. 25 cts. each, $\$ 2.50$ per doz.

\section{Dianthus barbatus (Sweet William)}

That old-fashioned favorite, the Sweet William, has almost disappeared from our gardens; more's the pity, for its place has been taken by plants of far less beauty. The Sweet William is a fine old plant which produces great masses of bloom of extremely rich and varied colors. The flowers are very lasting and fine for cutting. The plants offered are grown from the finest strains to be obtained in England, where hardy plants are universally grown and where new and improved varieties are constantly being produced. Fine large plants, 15 cts. each, $\$ 1.25$ per doz., $\$ 8$ per 100 .

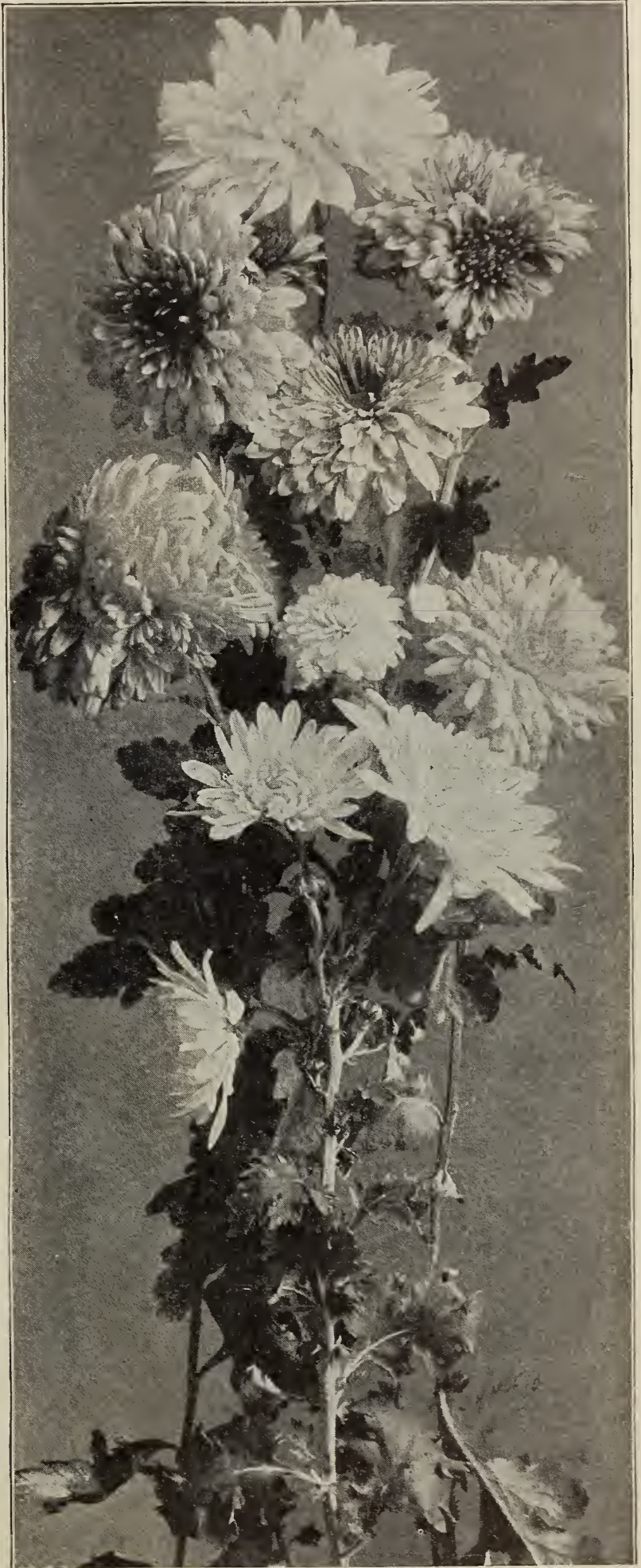

Hardy Chrysanthemums (see page 43 ) 


\section{Epimedium (Barrenwort)}

A genus of dwarf-growing plants with leathery foliage and panicles of lovely white, yellow and lilac-colored flowers. The foliage of all the varieties offered below assumes the most beautiful tints of color in autumn.

Lilacea. Beautiful lilac.

Niveum. Pure white. Muschianum. Creamy white. Sulphureum. Light yellow.

Any of the above four varieties, 20 cts. each, $\$ 2$ per doz.

\section{Hardy Ferns}

Varieties marked $*$ require shade; those marked $\dagger$ succeed in open border.

*Adiantum pedatum (Maidenhair Fern.)

*Aspidium acrostichoides (Wood Fern).

* " " marginale.

* “ Goldianum (Shield Fern).

†Asplenium ebeneum (Ebony Fern).

$\dagger \quad$ Filix-fœmina (Lady Fern).

* “ " Thelypteris.

$\dagger$ “ Trichomanes (Spleenwort).

†Dicksonia punctilobula (Gossamer Fern).

†Nephronium Filix-mas( Male Fern).

†noclea sensibilis (Sensitive Fern).

$\dagger$ " Struthiopteris (Ostrich Fern).

tOsmunda gracilis (Flowering Fern).

$\dagger$ " Claytoniana (Flowering Fern).

$\dagger$ cinnamomea (Cinnamon Fern).

$\dagger \quad$ " regalis (Royal Fern).

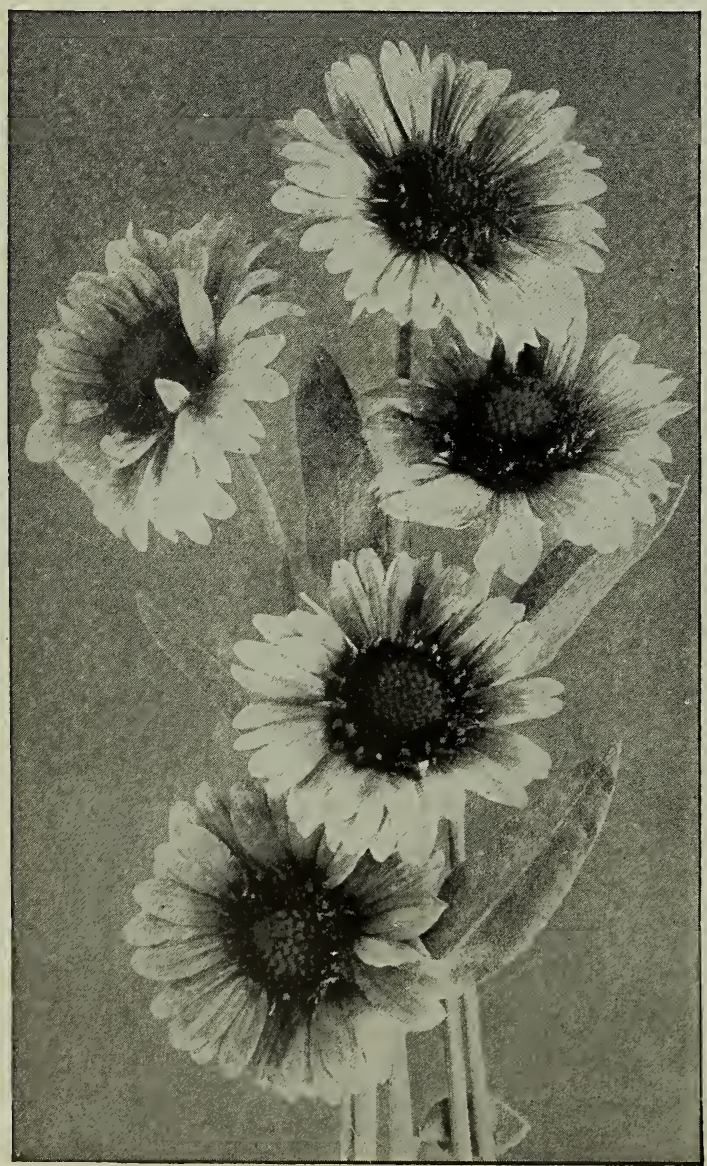

Improved Gaillardias

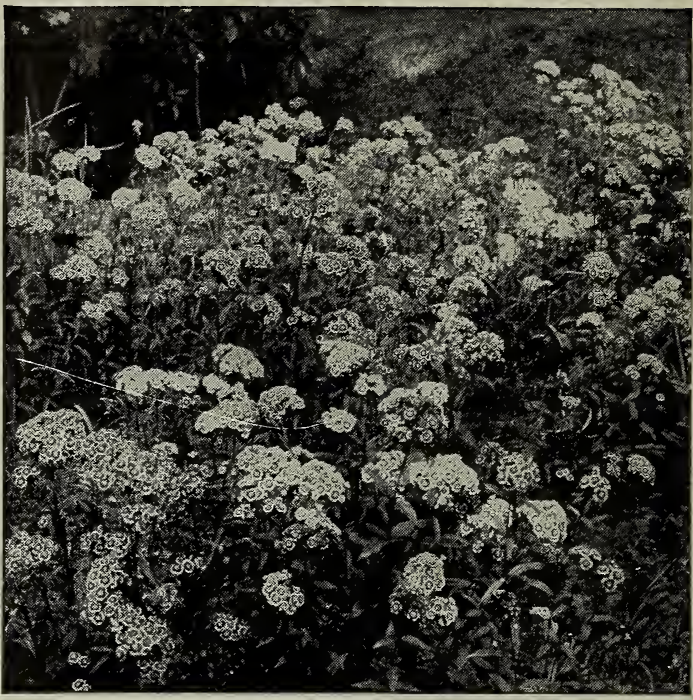

Dianthus barbatus (see page 35 )

HARDY FERNS, continued

*Phegopteris Dryopteris (Beech Fern).

$\dagger$ " hexagonoptera (Beech Fern).

†Polypodium falcatum.

Pteris aquilina.

*Woodsia obtusa.

*Woodwardia angustifolia (Chain Fern)

+ " Virginica.

Any of the above Ferns, 15 cts. each, $\$ 1.50$ per doz., $\$ 10$ per 100

\section{Foxglove (Digitalis)}

In England the Foxglove grows wild, but, notwithstanding this, it is a great garden favorite, as it well deserves to be. For stately and picturesque beauty it is not to be surpassed and, planted in masses in the garden among shrubs or naturalized on the edge of woods, in the orchard or along brooks, it is extremely effective and satisfactory. Strictly speaking, it is a biennial, but, as it renews itself from selfsown seed, it may be treated as a perennial. Mr. Falconer has naturalized thousands of Foxgloves in Schenley Park, and nothing he has planted attracts more attention and admiration. Planted in the fall, Foxgloves will bloom well the following season. I offer a fine lot of strong plants, grown from the best strains obtainable in Europe. 15 cts. each. $\$ 1.25$ per doz., $\$ 7$ per 100 .

\section{Improved Gaillardias}

We consider the Gaillardia one of the most beautiful and desirable hardy plants in cultivation, and have had a large stock of Kelway's famous strain grown for our customers. We offer these plants for less than they have ever been sold for, either in this country or Europe. Though such an ornamental addition to the herbaceous border, the perennial Gaillardia is content with extremely simple treatment. Dig the soil deeply and enrich with well-rotted manure. We recommend the Gaillardia for bedding purposes as well as for borders. Give a moderate amount of room and peg down, and a grand effect is to be obtained. Every one will have noticed how grandly Gaillardias have thriven through the recent drought; they seem hardly to need water, but we recommend watering liberally to insure the finest flowers. The Gaillardia which Kelway \& Son have been so successful in improving and popularizing is, of course, simply invaluable as a cutflower, on account of its being so lasting when gathered and so brilliant and beautiful. The gay blossoms are obtainable in perpetual profusion from June to November, and the greater the drought and scarcity of other flowers the more the utility of the perennial Gaillardia is demonstrated. No more brilliant and beautiful sight can be imagined than a large bed of Gaillardias, with their profusion of highly colored flowers of all shades. Some of the varieties of this improved strsin measure fully 5 inches in diameter. Mr. Robinson, in the English Flower Garden, recommends that they should be planted in bold groups, and remarks that no plants have finer effect in a bed by themselves, and we quite agree with him. Fixtra strong, fine plants, in a splendid assortment of colors, which will be sure to give complete satisfaction. $15 \mathrm{cts}$. each, $\$ 1.25$ per doz., $\$ 7$ per 100 . 


\section{Geum (Avens)}

Pretty border plants, growing about 18 inches high, and producing brilliant, showy, bright-colored flowers during the greater part of the summer and fall. ATROSANGUINEUM. Large, dark crimson flowers. COCCINEUM. Showy scarlet flowers.

15 cts. each, \$1 per doz.

\section{Helianthus}

Løtiflorus. The best of the summer-blooming varieties of hardy Sunflowers; flowers 3 inches in diameter and freely produced. Plant grows 3 to 4 feet high, and spreads rapidly. Fine for cutting, for the border, and for planting among shrubs. 15 cts. each, $\$ 1.25$ per doz., $\$ 7$ per 100 .

H. G. Moon. New. A grand seedling variety with abundance of large rich golden yellow flowers, rising well above the foliage, extra fine. Height 4 feet. August and September. Award of merit, R. H. S. 15 cts. each, $\$ 1.50$ per doz.

Miss Mellish. An improved variety of Helianthus latiflorus; of taller growth and having larger flowers. A decided improvement and most beautiful sort. 15 cts. each, $\$ 1.50$ per doz.

\section{Hibiscus Moscheutos}

We wish to call attention to this extremely showy and satisfactory plant. It thrives in any garden soil, and is equally desirable as a garden plant or naturalized along the edges of brooks and ponds, or planted among shrubs. The plant grows 4 or 5 feet high, is very bushy, and in August and September is covered with immense single flowers 6 to 8 inches across, from pure white to deep rose in color. The pink variety of this plant is the one that grows so abundantly in the Jersey meadows, consequently it is very desirable for marsh and swamp planting.

In separate colors. White, blush-pink and deep rose. $15 \mathrm{cts}$. each, $\$ 1.50$ per doz., $\$ 10$ per 100.

Mixed Colors. Strong plants at a specially low price. \$1 per doz., \$6 per 100 .

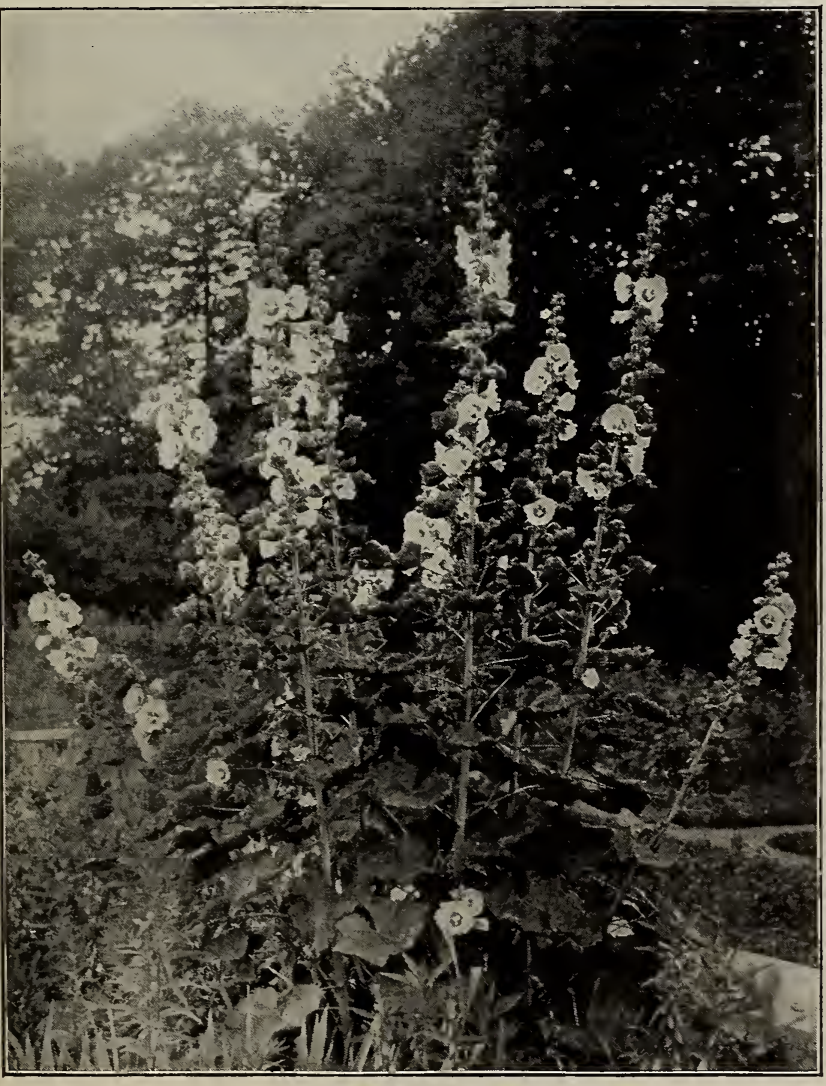

Single Hollyhocks

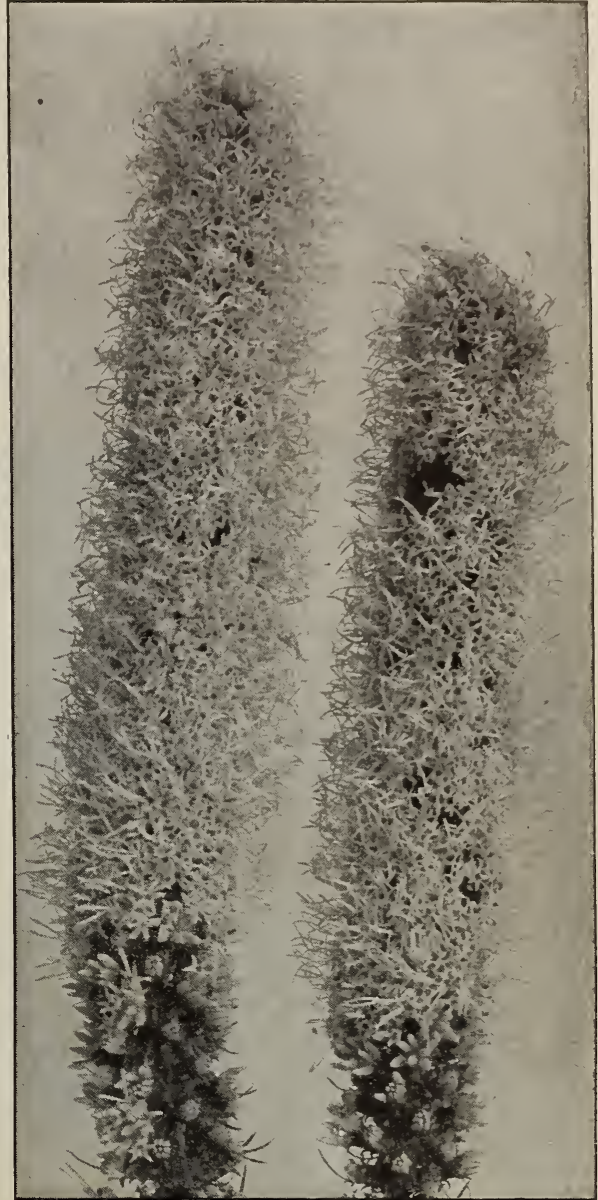

Liatris pycnostachya (see page 38 )

\section{Hollyhocks}

Have you ever noticed that painters choose single Hollyhocks as subjects for floral paintings oftener than any other flower. We suppose the reason for this is that artists have a keener appreciation of beauty than other people, and recognize that the common, and we fear sometimes despised, single Hollyhock, is one of the most stately, picturesque and beautiful plants in the world. Nothing can be more effective than a large group or mass of single Hollyhocks, and once planted they will literally take care of themselves, even if planted in the grass. We know of patches that have not been cultivated or disturbed in any way for twenty years. We are determined to have single Hollyhocks for our landscape gardening work, so we collected seed from old-fashioned (they will soon be new-fashioned) gardens and had thousands of plants grown for our customers. Some people think double Hollyhocks are more beautiful than single. They are mistaken, although the doubles are beautiful, but inclined to be top-heavy, often need staking and are liable to disease. Hollyhocks planted in the fall will bloom well the following summer.

\section{SPECIAL OFFER OF HOLLYHOCKS}

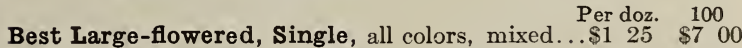
Best Large-flowered, Double, mixed colors...... 125800 Chater's Famous Strain. Best double grown.

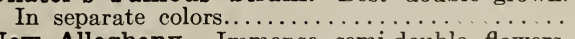

with fringed edges; very beautiful..Each, 15c... 1501000

Our Hollyhocks are free from disease, and to ensure this we are having them grown in Ohio in soil which is entirely free from the Hollyhock disease. 


\section{Heliopsis pitcherianus}

A desirable hardy herbaceous plant, growing from 2 to 3 feet high; a perpetual bloomer, beginning to "flower early in the season, and continuing in bloom the entire summer. The flowers are of a beautiful deep golden yellow color, about 2 inches in diameter, of very thick texture, and are very graceful for cutting. 15 cts. each, $\$ 1.25$ per doz., $\$ 6$ per 100 .

\section{Festuca glauca}

A dwarf grass with very distinct blue foliage. Does not grow over 8 or 10 inches high, and is very effective. 25 cts. each, $\$ 2.50$ per doz.

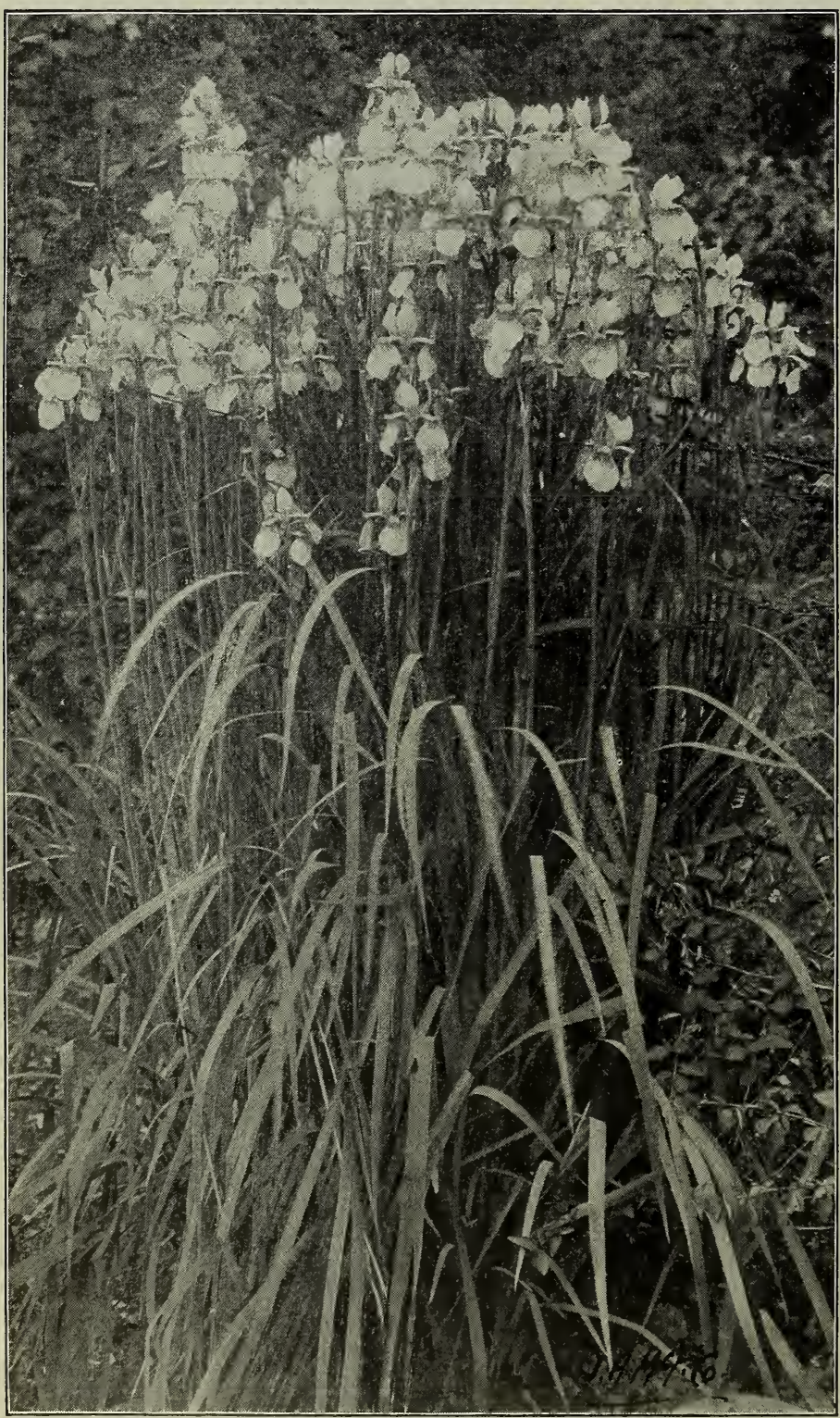

Iris tectorum

\section{Vitis coignettiæ}

This grand wild grape-vine from Japan is of remarkably rapid growth, and the foliage turns to a rich wine-color in the fall. Not sufficiently hardy in the North, but south of Philadelphia it is most valuable. $40 \mathrm{cts}$. each, $\$ 4$ per doz.

\section{Two Useful Irises}

TECTORUM. This is a beautiful white Iris, resembling I. Sibirica in habit and blooming at the same time-early in June. It is extremely vigorous and hardy, and very valuable either for the garden or for naturalizing on the edge of ponds or streams. $10 \mathrm{cts}$. each, $\$ 1$ per doz., $\$ 5$ per 100 .

SIBIRICA SANGUINEA. This is the best of the Siberian Irises, and is extremely desirable in every respect. The brilliant blue flowers are freely produced. The plant grows with great vigor and is perfectly hardy. Splendid for the garden, and nothing finer for naturalizing. 10c. each, 75c. per doz., $\$ 5$ per 100 .

\section{Leontopodium alpinum}

(Edelweiss, or Alpine Snowflower)

Well known to tourists who have traveled in Switzerland. It is a hardy plant, and well worth a trial. It should be grown either on the rockery or in welldrained, sandy soil. 15 cts. each, $\$ 1.50$ per doz.

\section{Saponaria ocymoides splendens}

A charming creeping plant, even prettier than the creeping Phloxes. It is quite as free-flowering, and piles itself up in masses that are lovely bevond description; beautiful bright pink flowers produced in June. One really good thing that should be in every garden. Pot-grown plants, 15 cts. each, $\$ 1.50$ per doz.

\section{Liatris pycnostachya}

The popular name of this striking plant is Kansas Gay Feather. Nothing can be planted that will attract more attention on account of its very unusual appearance; but it is very beautiful as well as odd. It blooms in midsummer and throws up long, narrow spikes of rich purple flowers, which last a long time. A peculiarity of this plant is its great attraction for butterflies; when in bloom it is always surrounded by them. See illustration on page 37 . 15 cts. each, $\$ 1.50$ per doz., $\$ 8$ per 100 .

\section{Lychnis splendens, Double Red}

\section{(Ragged Robin)}

Forms a dense tuft of evergreen foliage, and in June it sends up tall spikes of handsome double, deep red flowers of exquisite fragrance, which remain in perfection six weeks. 15 cts. each, $\$ 1.50$ per doz.

\section{Tufted Pansies, or Bedding Violas}

The tufted Pansies are hybrids of Pansies and Viola cornuta, and are quite distinct from Pansies in habit and coloring, and we think far more beautiful. The flowers are smaller, but unique in coloring, and the plants spread from the roots like a violet, making them true perennials. They are perfectly hardy, enduring the extremely cold weather of 1898-99 in an open border without protection. They are immensely popular in England and Scotland, where they are generally used for bedding and table decorations, and nothing can be more charming for either purpose. We have always admired these flowers in England, but were not certain that they would thrive in this climate, but after testing them a year in our garden we are convinced that they will do as well here as they do abroad. We have had a splendid lot of plants grown from the best collections in Scotland. They can be planted in the summer, fall or spring. In separate colors or mixed. $15 \mathrm{cts}$. each, $\$ 1$ per doz., $\$ 6$ per 100 . 


\section{Mertensia Virginica (Blue Bells)}

An carly spring-flowering plant, growing, about 1 to $1 \frac{1}{2}$ fect high, with drooping panicles of handsome light blue flowers, fading to clear pink. One of the most interesting of our native spring flowers. May and June. $15 \mathrm{cts}$. each, $\$ 1.50$ per doz.

\section{Oriental Poppies}

I remember very well the first time I saw an Oriental Poppy. I was a boy theu, and it excited me wonderfully, and I thought it the most remarkable flower in the world; and now, after twenty-five years have gone by and I have seen almost all the known flowers of the world, I am still of the opinion that it is mighty fine, striking and effective, and I have taken the trouble to gather and have grown a collection of several varieties. The foliage of Oriental Poppies dies away in the summer, and many think they are dead, but they will start into growth again in the fall. They are rather hard to establish, but, once established, prove the most persistent perennial.

Orientale. The type. Immense orange-red flowers, 8 to 12 inches in diameter............. $\$ 8$ per $100 . \$ 0 \quad 15 \quad \$ 1 \quad 50$

Orientale, Brightness (Bracteatum). Flowers rich glowing salmon,crimson-brown blotch at base of petal

Orientale, Fire King. New. Large, fiery scarlet flowers with glittering black center; very handsome; $2 \frac{1}{2}$ feet high.

$20 \quad 200$

Orientale, Royal Prince. Large, brilliant scarlet

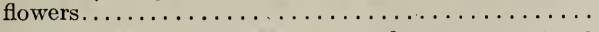

Orientale, Salmon Queen. Large, handsome, soft salmon-scarlet flowers...

Orientale, Trilby. Beautiful cerise-scarlet, with handsome black spots at base of petals; distinct and extra fine; not very hardy. .

Orientale, Duke of Teck. Large brilliant crimsonscarlet flowers, handsome; $2 \frac{1}{2}$ feet high...........

Orientale, Masterpiece. New. Flowers very large and handsome, of the palest salmon-pink, slightiy tinged mauve, borne on stiff stems; extra fine.......

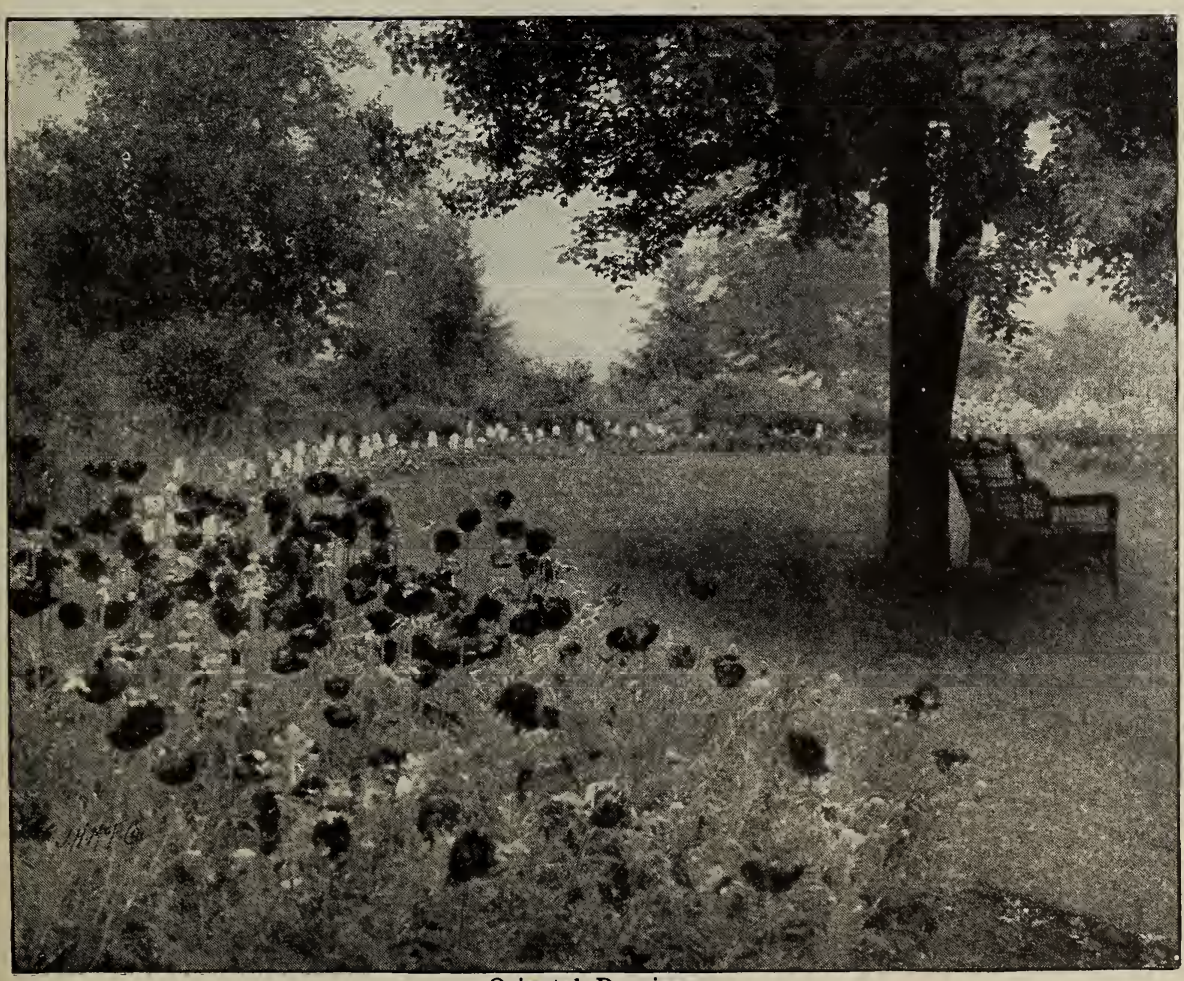

Oriental Poppies
ORIENTAL POPPIES, continued

Orientale multiflorum. Large, deep blood-crimson Each Perdoz flowers of medium sizc; frec bloomer and early; 3 feet

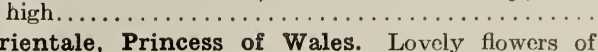

satiny gray, shot with pink; very similar to Masterpiece......

Orientale, scarlet Giant. Dazzling scarlet, with glittering black blotch at base of petals. $3 \mathrm{ft}$. high. .

Monarch. Brilliant orange-scarlet, with black blotches; sturdy, erect grower.

Mahony. Deep maroon, very distinct, but not very handsome variety

Novelty. Glowing crimson; a handsome late-flowering six -petaled variety.

Queen Alexandra. Flowers cup-shaped; soft, satiny salmon-pink, with black blotches.

\section{Genista scoparia elatior}

At last we have a Genista, or Broom, that is perfectly hardy in this climate. All know the yellow-flowered Gienistas that the florists sell for Easter at prices ranging from two to ten dollars each. This hardy Genista is just as beautiful as these and can be grown in any one's garden or shrubbery. It is of slow growth, but eventually reaches a height of 3 to 4 feet and as many feet across. In June it is covered with beautiful yellow pea-shaped flowers which continue a long time on the plant. We consider this one of the most valuablc small shrubs introduced during many years. Strong pot-grown plants, $25 \mathrm{cts}$. each, $\$ 2.50$ per doz.

\section{Saxifraga cordifolia}

This, the only Saxifraga, or Rockfoil, that is hardy in this climate, is distinguished by its large, handsome, shiny foliage, and its dense panicles of lovely pink flowers which are produced very early in the spring. $20 \mathrm{cts}$. each, $\$ 2$ per doz.

\section{Hardy English Ivies}

20200 We have a fine stock of pot-grown plants suitable for early fall or spring planting. These Ivies are hardy if planted against a north wall. 25 cts. each, $\$ 2.50$ per doz., $\$ 16$ per 100 .

\section{Southernwood}

Artemisia abrotanum (Soutlernwood, or "Old Man"). 15c. each, $\$ 1.50$ per doz.

Artemisia stelleriana. A trailing species with handsome silvery gray foliage; 6 inches high. $10 \mathrm{cts}$. each, $\$ 1$ per doz.

\section{Wallflowers}

The old favorite fragrant Wallflower; mixed colors, including yellow, brown, etc. 15 cts. each, $\$ 1.50$ per doz., $\$ 10$ per 100 .

\section{Cerastium}

\section{(Snow-in-Summer)}

Tomentosum. A desirable lowgrowing plant with silvery foliage and white flowers, suitable for the rockery, or for carpeting dry, sunny spots, such as covering graves or steep banks. 15 cts. each, $\$ 1.50$ per doz., $\$ 8$ per 100.

Biebersteinii. Similar to $C$. tomentosum, but the flowers are very much more beautiful. The plant is dwarf and covers the ground with a mat of silvery foliage which is almost evergreen. The starry flowers are white and extremely beautiful. They are produced freely in June. The plant is for the rockery, covering dry banks or edging borders. $15 \mathrm{c}$. each, $\$ 1.25$ per doz., $\$ 8$ per 100 . 


\section{Platycodon}

Mariesi. A valuable dwarf variety, bearing blue bellshaped flowers nearly 3 inches across, for a long season in late summer and early autumn. One of the finest of border plants. The unopened buds are nearly as beautiful as the flowers themselves, and are particularly interesting in their peculiar shape. Extremely effective when planted in groups. 15 cts. each, $\$ 1.50$ per doz., $\$ 10$ per 100 .

Mariesi nana. The Platycodon, or Wahlenbergia, has been for many years one of the most popular hardy plants, and deservedly so. This new variety is a decided improvement, as the plants are dwarfer and more compact, and never fall over. Beautiful white or blue bell-shaped flowers produced in the greatest profusion. This new plant is to be highly commended. Price of either white or blue variety, 15 cts. each, $\$ 1.50$ per doz., $\$ 10$ per 100 .

\section{Polygonum cuspidatum}

A magnificent plant for producing bold masses of foliage, growing 8 feet high in good soil. Numerous fragrant white spirea-like flowers issue from the axils of the leaves. A stately plant for large flower-borders, shrubberies, wild gardens, banks of streams and ponds and for growing beneath large trees. 15 cts. each, $\$ 1$ per doz., $\$ 6$ per 100 .

\section{Pyrethrums}

The Pyrethrums are so simply and easily cultivated that they may be recommended to all who possess a garden, whether small or large. They are perfectly hardy and absolutely invaluable for cut-flowers through the summer and autumn months. The flowers are bright and elegantly borne on long stems; most convenient for vase-decoration. In form the double varieties are somewhat aster- or chrysanthemum-like, and as their chief beauty is in the months of May and June, they may well be designated Spring Chrysanthemums. possessing the advantage over the chrysanthemums of being able to withstand the severest winter without protection. The single-flowered varieties are veritable colored marguerites and possess a range of color and hardiness that marguerites might envy in vain. Nothing can surpass the Pyrethrum for profusion of flowers in the season; flowers succeed flowers without stint, and the blossoms are not injured by storm or sun. Their position should be in the border or in beds. The plants may, with advantage, be cut down after June, which will keep up a greater succession of bloom through the autumn. Pyrethrums grow freely in any ordinary garden soil; a good rich loam suits them, perhaps, best. and in order to secure size, brilliancy and number of flowers, plenty of ordinary well-rotted manure may be added to well-trenched, well-drained soil, and plenty of water may be given when they are in bud in the dry summer weather. A mulching may be applied in dry localities with advantage. The older varieties have been greatly improved upon during the past ten or fifteen years, which is the period during which Kelway \& Son have made them a specialty, and the refined shape and brilliant or soft shades of the newer sorts have caused the Pyrethrum to become deservedly popular. We offer a splendid lot of plants of the choicest single varieties grown from Kelway's famous strains.

All Colors Mixed. 15 cts. each, $\$ 1.50$ per doz., $\$ 9$ per 100 .

\section{Rudbeckia, "Golden Glow"}

This hardy plant of recent introduction is entitled to rank with single hollyhocks for picturesqueness. In good soil it grows from 8 to 10 feet high, branches freely, and for two months in midsummer is literally covered with its large, bright yellow, double flowers. As a garden or lawn plant it is extremely decorative, and equally so as a cut-flower, and very lasting. We have used this a great deal in our landscape work, and have found a large circular group of it surrounded by the dwarfer Rudbeckia speciosa extremely effective. $10 \mathrm{cts}$. each, $\$ 1$ per doz., $\$ 7$ per 100 .

\section{Hieracium aurantiacum (Hawkweed)}

A low-growing, rapid-spreading plant, best adapted for dry, sandy spots or for covering steep slopes. The flowers are borne in flat heads and are of a bright orange-red. $15 \mathrm{cts}$. each, \$1 per doz., \$6 per 100 . 


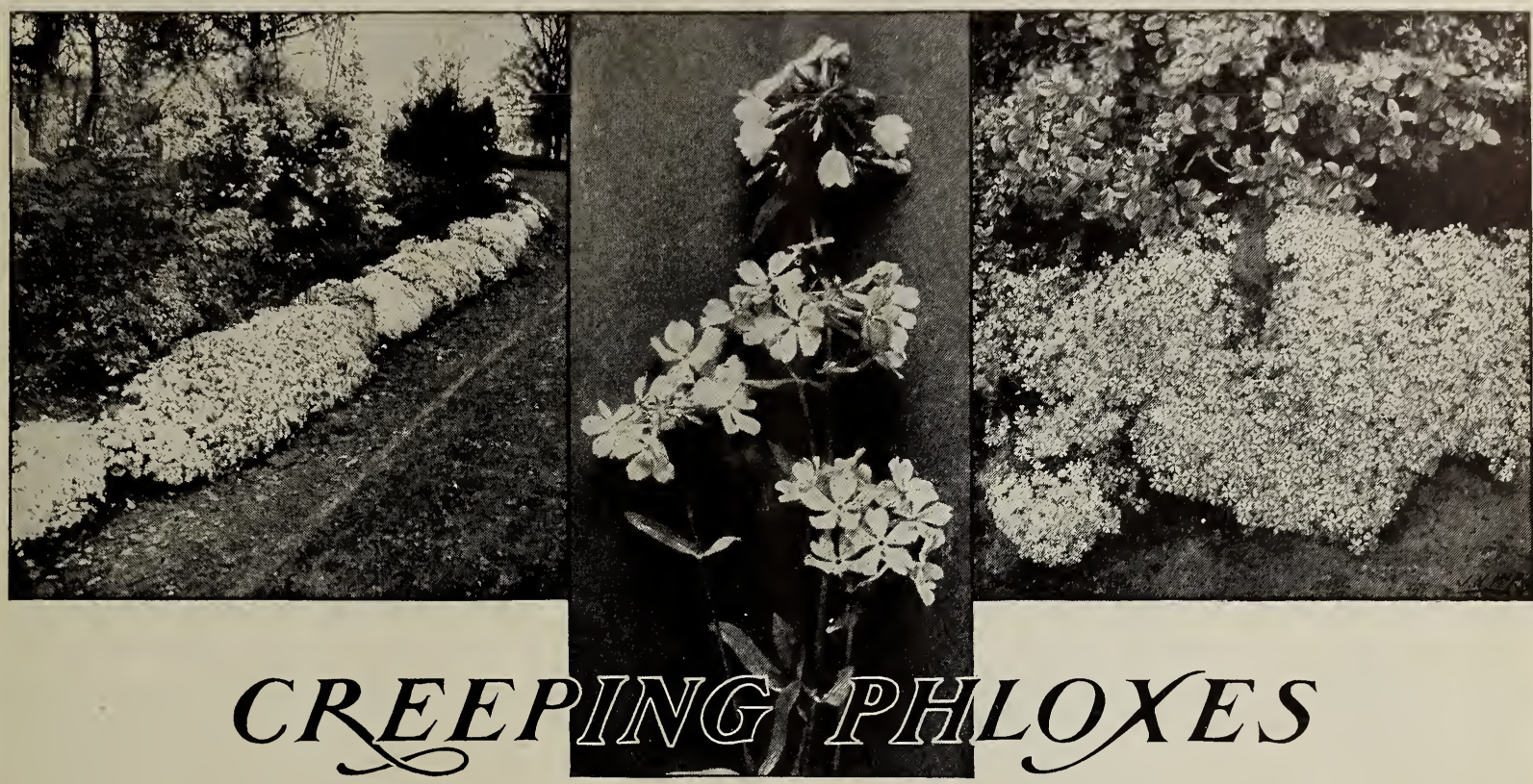

The Creeping Phloxes have a charming beauty all their own, and, for general usefulness, are not to be surpassed by any flower that grows. They will thrive in any situation, except a very shady one; and in any soil, no matter how poor, unless it is very wet. They are absolutely hardy without protection; hardy last winter, which killed millions of plants and shrubs, and even trees. They have neat evergreen foliage, and, when in bloom, which is during the month of May, their multitude of lovely pink, white or blue flowers cover everything beneath as completely as a carpet covers a floor. They bloom again in September, but not so freely. For covering rocky hillsides, sandy slopes, bare ground too poor to grow anything else, or for edging borders of hardy plants or shrubs, they are unsurpassed. Our President literally uses these plants by hundreds of thousands in his landscape work, and wherever he uses them there is a large demand for them. Just think of it! These splendid, inexpensive hardy plants, which increase fourfold every year, are almost unknown, while commonplace geraniums, with not one-tenth their beauty, are planted by the million, and must be planted annually.

The CREEPING PHLOXES can be planted advantageously in September and until the fifteenth of October. As we grow them by the acre, we can offer them in quantity at very low prices, which are given below.

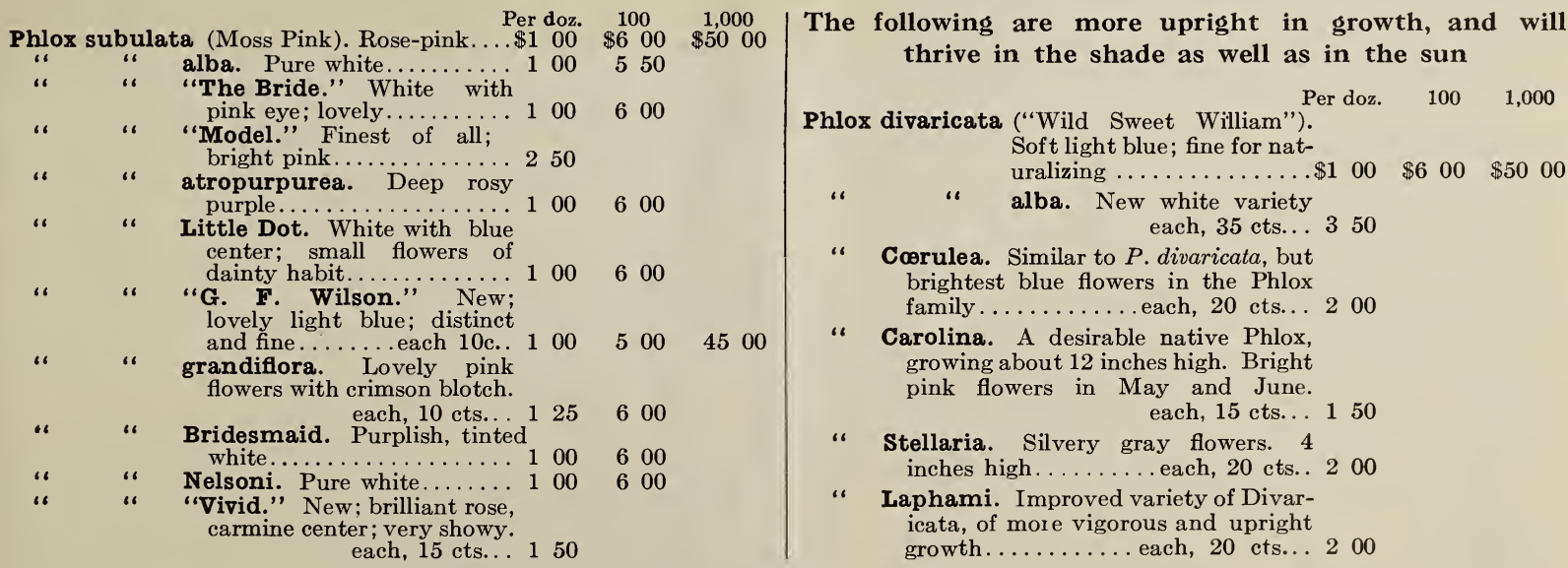

\section{Anchusa Italica, Dropmore Variety}

One of the most important hardy plants of recent introduction, and a grand improvement on the original type of $A$. Italica, or Italian Alkanet, and a plant which, on account of its remarkable freedom of flowering and its beautiful blue color, is sure to become one of our most popular Hardy Perennials. It attains a height of 5 or 6 feet, and produces its pretty blue flowers, which are from 1 to $1 \frac{1}{4}$ inches in diameter, throughout the entire summer. $25 \mathrm{cts}$. each, $\$ 2.50$ per doz. 


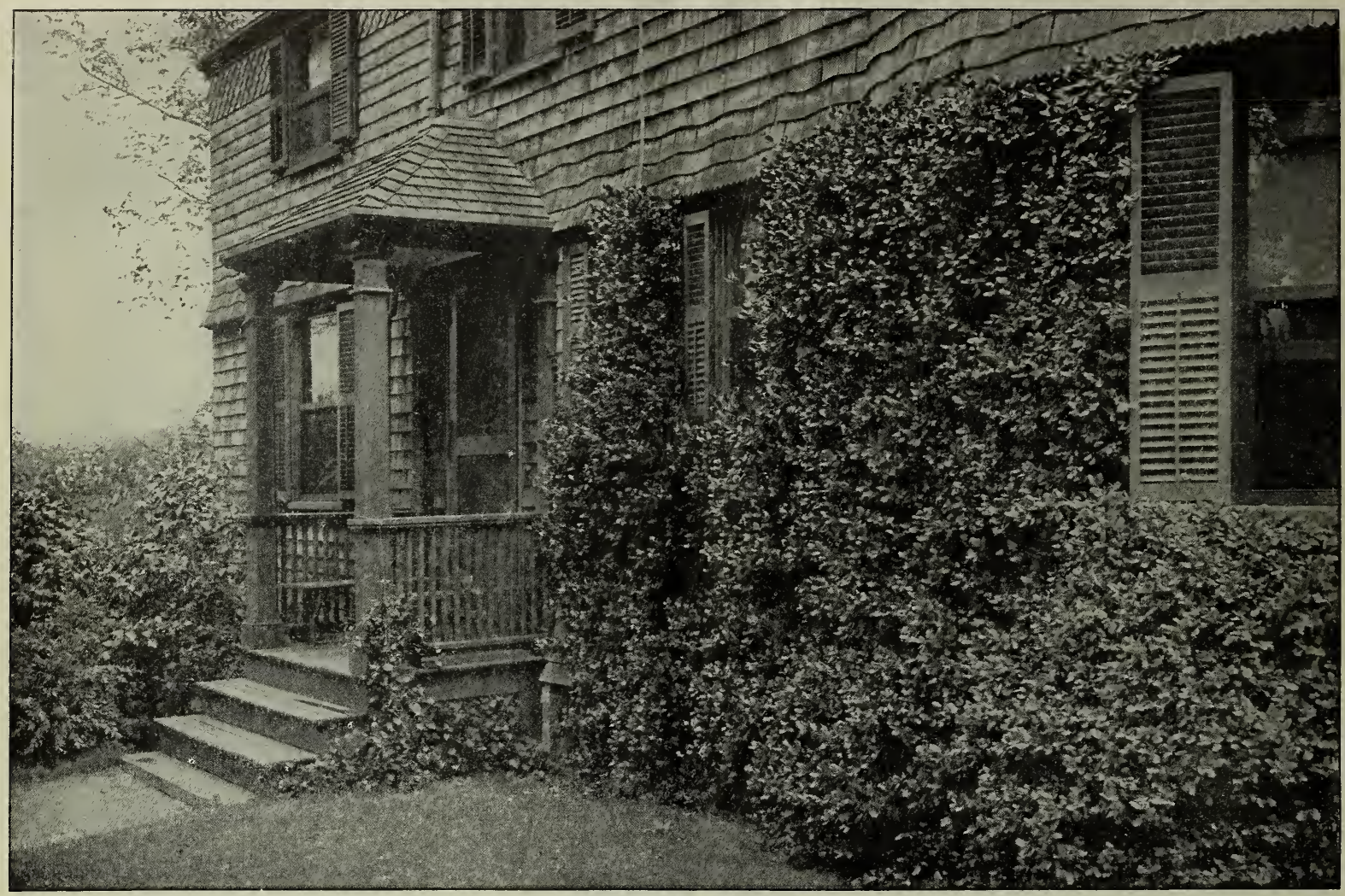

Euonymus radicans

\section{Hardy Climbing Plants}

\section{ACTINIDIA arguta}

AKEBIA quinata

AMPELOPSIS Veitchii.

Extra strong pot-grown plants.

Quinquefolia (Virginia Creeper)

ARISTOLOCHIA Sipho (Dutchman's Pipc)

Extra strong...........

BIGNONIA radicans (Native Trumpet

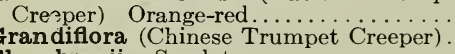

Thunbergii. Scarlet.

Madam Galen. Dark red; free bloomer.

CELASTRUS scandens (Bitter Sweet)

Paniculata. New variety from Japan.

Very handsome, vigorous vine, with splendid showy fruit.

\section{CLEMATIS coccinea}

Henryi. Best large-flowered; white

Vitalba.

Jackmani.

Extra large.

Paniculata. New; extra-strong plants.

Crispa

Firginiana.

DOLICHOS Japonicus (Japanese Hardy Bean). The fastest-growing vine in cultivation.

EUON YIMUS radicans variegata. A most beautiful evergreen vine, suitable for covering low walls or for carpeting the ground. For covering the wolls of a house for a few feet only, nothing can be finer

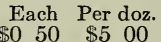

$\$ 500$

$20 \quad 175$

$35 \quad 350$

$\begin{array}{llll}35 & 3 & 50 \\ 20 & 2 & 00\end{array}$

$\begin{array}{lll}50 & 5 & 00\end{array}$

$\begin{array}{lrr}00 & 10 & 00\end{array}$

$25 \quad 250$

$25 \quad 250$

$30 \quad 300$

$\begin{array}{lll}35 & 3 & 25 \\ 35 & 3 & 50\end{array}$

$\begin{array}{lll}35 & 3 & 50 \\ 25 & 2 & 50\end{array}$

\section{$40 \quad 4 \quad 00$}

$25 \quad 200$

$50 \quad 500$

$25 \quad 200$

$50 \quad 500$

$\begin{array}{llrr}100 & 10 & 00\end{array}$

$\begin{array}{lll}25 & 2 & 50\end{array}$

$25 \quad 200$

$\begin{array}{lll}25 & 2 & 50 \\ 25 & 2 & 50\end{array}$

100

$\$ 1200$

1100

1400

1600

1600

1500

$50 \quad 500$

20
EUONYMUS radicans. A splendid ever- Each Per doz.

100 green vine of slow growth and elegant rich green foliage. In Erie we saw the walls of a stone house covered with this vine. It was the finest vine effect we have ever seen

on a house and just as fine in winter as it

is in summer. .......................

HONEYSUCKLE, Lonicera Japonica (Everreticulata (Golden), 2 yrs. or pot-grown.

Heckrotti. A supcrb and scarce sort; undoubtedly the finest Honeysuckle in cultivation.

LYCIUM Chinense (Matrimony Vine).

MENISPERMUM Canadense (Moonseed).. PERIPLOCA Græca (Silk Vine). .

POLYGONUM Baldschuanicum. A new and vigorous-growing climber that is attracting a great deal of attention in England. Very free-flowering; the small branchlets bear large panicles of purc

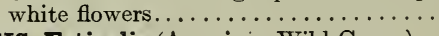

VITIS AFstivalis (American Wild Grape).

Riparia (American Wild Grape)

Odorata (Sweet-scented Wild Grape). Fragrant.

Variegata. Beautiful variegated foliage... WISTARIA Sinensis. Purple.

Sinensis alba. White

Multijuga (Japanese Wistaria). A superb variety, with racemes of flowers often 3 feet long.

Multijuga alba. White-flowered...........
Frutescens. Our native Wistaria; flowers in the summer time.
$\$ 0 \quad 20 \quad \$ 200$

$\$ 1200$

$\begin{array}{lllll}20 & 2 & 00 & 14 & 00\end{array}$

$20 \quad 200$

$20 \quad 200$

$25 \quad 250$

$40 \quad 4 \quad 00$

75

$20 \quad 200$

$15 \quad 150$

1000

$25 \quad 250$

$25 \quad 250$

30300

$\begin{array}{lll}30 & 3 & 00 \\ 50 & 5 & 00\end{array}$

$17 \quad 00$

$30 \quad 300$

$\begin{array}{lll}30 & 3 & 00\end{array}$

$25 \quad 250$ 


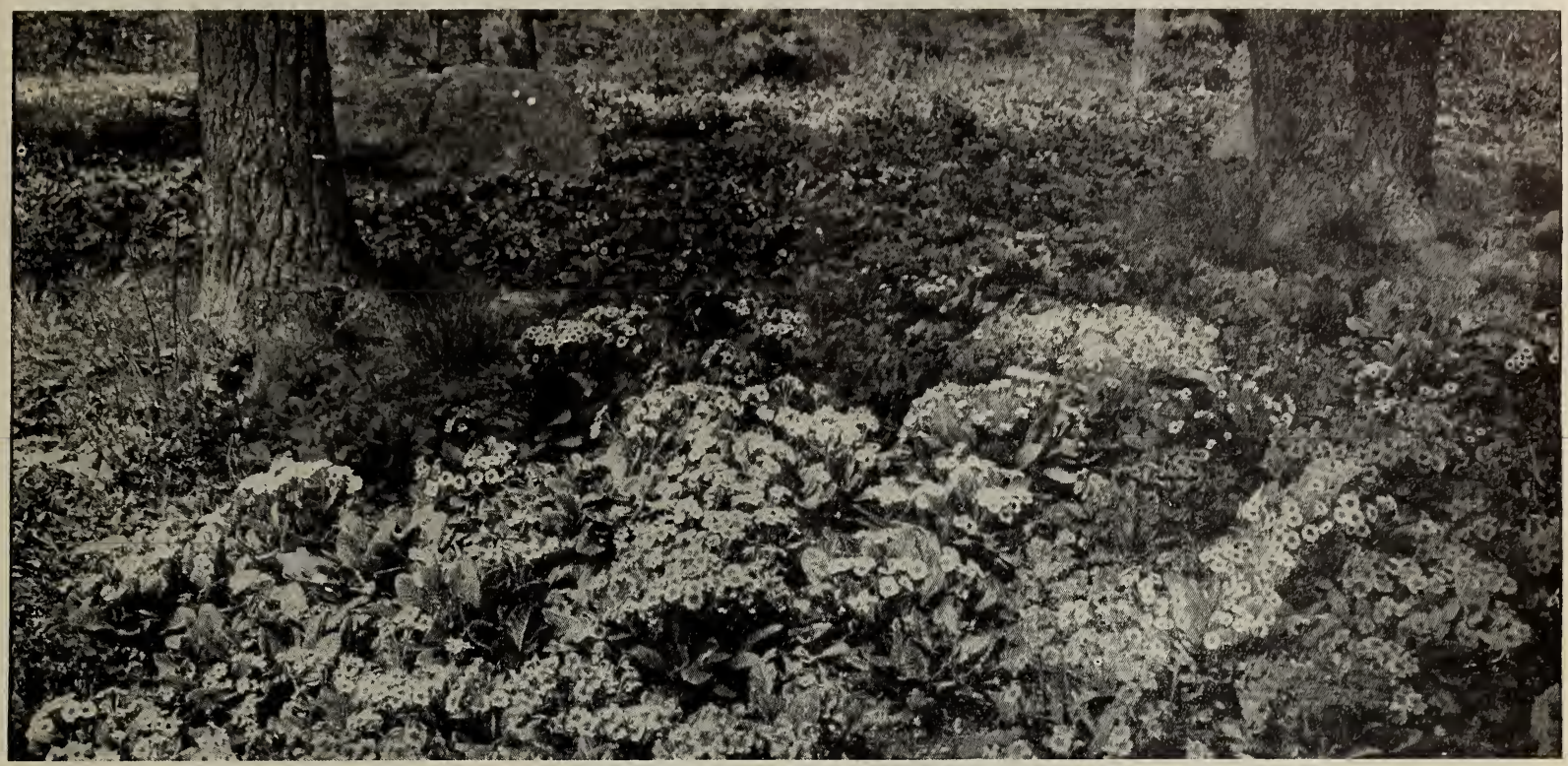

Polyanthus naturalized (see page 35 )

\section{HARDY PLANTS (Herbaceous Perennials)}

Until hardy plants come into ganeral use we cannot hope for artistic, interesting and beautiful gardens in this country. People of taste and culture are realizing the ugliness of the stereotyped bedding with. lines of color, and will no longer allow their lawns to be daubed with a flower garden like a colored lithograph, although many of our public parks are still guilty of this atrocious work. With the material offered in this list, the most beautiful and interesting gardens are to bc made, gardens that increase in interest and beauty year after year gardens that change their aspect with every change of season. To make a garden with hardy plants and shrubs requires far more taste and knowledge than it does to make one with the few varieties of bedding plants generally used, but the majority of gardeners do not have this knowledge, and have no idea of proper arrangement. But the garden of hardy plants has this advantage: the individual beauty of the plants themselves is so great that a garden cannot fail to be interesting and lovely, no matter how badly arranged, if the cultural skill is sufficient to bring them to perfection. One of the most effective ways of using hardy plants is to plant in a wide border in front of a hedge or shrubbery. The trouble with this arrangement is that the roots of shrubs or hedge get into the border and rob the plants of a large share of their food. This can easily be prevented by placing a sunken wall of concrete between the hedge or shrubbery and border. This wall need be only 2 feet deep and 4 inches thick, and is inexpensively constructed of gravel and cement. Another very effective arrangement is two broad borders through the vegetable garden, with a broad grass walk between them. The effect will be enhanced by building trellises back of the borders and covering thém with climbing roses or flowering vines.

Cultivation is of the simplest: beginning with any good garden soil, deeply dig it and enrich it with old rotted stable manure. The best time to plant hardy perennials is when they are just starting into growth in the spring or carly in the fall. The soil should be comparatively dry when plants are set out. Avoid wet planting. Do not make the mistake of planting too thickly. The nearest approach to a rule which may be followed in planting is to set out plants.which grow to a height of 2 feet or less, 12 inches apart, and all taller onehalf their height. For example, Aquilegias and Coreopsis which grow 2 feet high may be planted 12 inches apart, whilc Delphinirum formosum and Japanese Iris which grow 3 feet high, should be 18 inches apart.

During the summer, the soil about the plants should be frequently stirred and weeds kept down. During hot, dry weather, or when it is not convenient to water, a mulch of any loose, light material is very beneficial in retaining the moisture and preventing the ground from baking; grass clippings from the lawn are excellent material for this purpose.

About the middle of November, or later, when all soft growth has been killed and the plants are thoroughly ripened, the old hardwooded stems should be removed and burned. Then cover the plants with 2 or 3 inches, not more, of loose strawy stable manure. Care must be taken, however, not to cover the foliage of evergreen plants such as Phlox subulata, Hardy Pinks and Candytuft, as such a covering would cause the foliage to rot and kill the plants.

Most hardy plants which flower during the spring or early summer months, such as Peonies, Anthericums, Dielytras, Funkias, German Iris, etc., are better left undivided and undisturbed for several years, but they should be given a liberal dressing of stable manure or other fertilizer every spring. The late-flowering plants, like Phloxes, Helianthus, Rudbeckias, Asters, Boltonias, Physostegias, etc., are better for being replanted at least every two years. The Japanese Anemones are an cxception; they shou'd be allowed to remain undisturbed for several years.

\section{SPECIAL OFFERS OF HARDY PLANTS IN VARIETY}

The plants in the following collections will be of the best and most desirable varieties and the plants of the best quality, but in every instance the selection of varieties is to be made by us; but if purchasers will state the things they have, or don't wish, these will not be in cluded in the selection. Sometimes people writc asking for a list of the plants contained in these collections. This can not be given, so please save us the unpleasantness of refusing by not asking for it.

Offer No. 1 of Hardy Plants. Twenty-five first-class plants in variety for

offer No. 2 of Hardy Plants. Fifty first-class plants in variety for

Offer No. 3 of Hardy Plants. One hundred first-class plants in varied assortment of best species and varieties for

Offer No. 4. Five hundred Hardy Plants, same as above, but in larger variety, for

Offer No. 5. One thousand Hardy Plants, same as above, but in much larger variety, for...

$\$ 250$

In the following list height and time of blooming are indicated as follows: Figures following the lctter $\mathrm{H}$ indicate height in feet figures following the letter $\mathrm{F}$ indicate the number of the month or months the plants bloom in. This is only approximate, as height and time of flowering vary considerably with soils, climates and seasons.

Plants suitable for growing in the shade are marked *. For growing in partial shade are marked $\dagger$

Prices quoted are for not less than half the quantities named, but single plants will be furnished at following low rates: Plants at $\$ 1$ or less per doz., 10 cts. each; plants at $\$ 1.25$ and $\$ 1.50$ per doz., 15 cts. each; plants at $\$ 1.75$ and $\$ 2$ per doz., 20 cts. each; plants at $\$ 2.50$ and $\$ 3$ per doz., 25 cts. each. 


\section{HARDY HERBACEOUS PERENNIAL PLANTS, continued}

Per doz, 100

*ACONITUM Napellus (Monkshood). Beautiful but poisonous plant with blue flowers...........2 50

ACHILLEA Ptarmica fl. pl. One of the most useful plants; numerous and dense masses of white flowers; fine for cutting. $\mathrm{H} 1$ to $2, \mathrm{~F} 6$ to $10 \ldots \ldots 100 \$ 600$

Millefolium roseum. Red flowers produced in profusion for a long season; little known in this country but very popular in England. $\mathrm{H} 1$ to 3 , F 4 to $10 \ldots \ldots \ldots \ldots \ldots \ldots \ldots \ldots \ldots \ldots \ldots \ldots \ldots \ldots \ldots \ldots$. Egyptica. Sulphur-yellow flowers; silvery gray "The Pearl." An improvement of Ptarmica fl. pl.

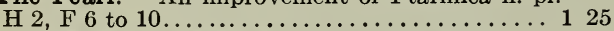

ÆTHIONEMA grandiflora. Flowers in rosy racemes $\mathrm{H} 2, \mathrm{~F} 5$ to 8 ...

AGROSTEMMA coronaria. Perdoz. 100 Beautiful rich crimson flowers. H $1 \frac{1}{2}$, F 7......... $\$ 125 \$ 800$

Coronaria alba. Pure white. 125800 Coronaria atrosanguinea. Brilliant dark crimson..... 12525800

Coronaria bicolor. White and red.

125

Flos Jovis. Extremely desir-

able rose-tinted flowers

fine for cutting. $\mathrm{H} 1 \frac{1}{2}, \mathrm{~F} 7 \quad 125 \quad 800$

ALSTRCMMEIA Chilensis (Chilian Lily). A tuberousrooted plant 2 feet high, with spikes of showy flowers varying from rosy white to deep orange and red, flowering from July to September. In exposed situations requires protection... 150

ALYSSUM saxatile compactum. Masses of golden yellow flowers. Invaluable for spring flowering. $\mathrm{H} 1$, F 4 . .

*AMSONIA Tabernæmontana. Desirable perennial with lead-colored blue flowers. $\mathrm{H} 2, \mathrm{~F} 5$ to 6 .

150

*ANemoNe Pennsylvanica. A beautiful native Anemone. Fine for naturalizing $\mathrm{H} 1 \frac{1}{2}, \mathrm{~F} 6$. 150

Japonica rosea. Purplish rose. $\mathrm{H} 3$ to $5, \mathrm{~F} 9$ to 10 . 150

†Japonica rosea elegans. Improved variety. H 3 to $5, \mathrm{~F} 9$ to 10 .

$150 \quad 1000$

†Japonica alba. White. H 3 to $5, \mathrm{~F} 9$ to 10 . 150

$\dagger$ Japonica, Whirlwind. New semi-double variety. White $\mathrm{H} 3$ to 5 , F 9 to 10 $150 \quad 800$

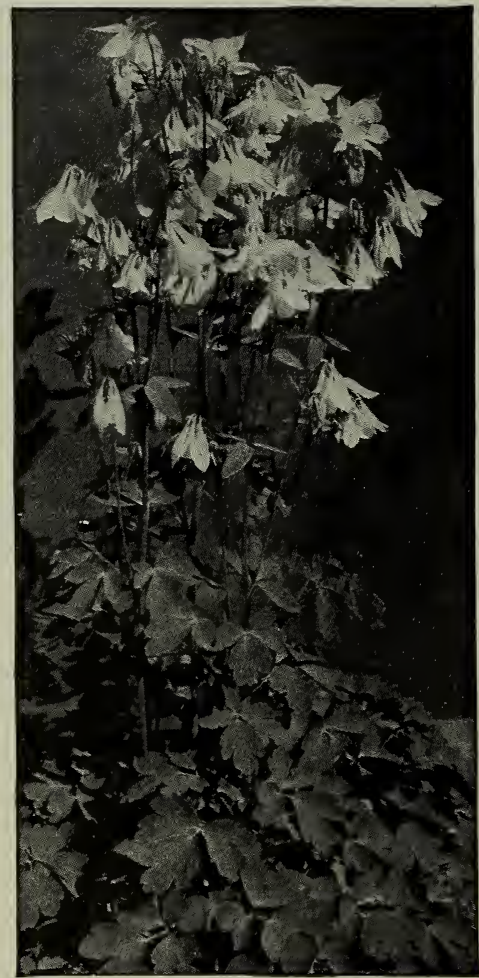

Aquilegia
Ter doz. 100 The most beautiful of all Columbines; one of the most charming hardy flowers in cultivation.

$\mathrm{H} 1 \frac{1}{2}, \mathrm{~F} 4$ to $5 \ldots \ldots \ldots \ldots \ldots \ldots \ldots \ldots \ldots \ldots \$ 175 \$ 1000$

Corrulea lutea. New; large, light yellow flowers.

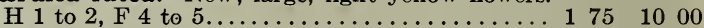

†Chrysantha. Beautiful golden yellow flowers; blooms for two months. H 3 to $4, \mathrm{~F} 5$ to $6 \ldots \ldots, 150 \quad 800$

†Chrysantha alba. A white variety of the above.. 125800

tCanadensis (native). Red and yellow. H 1, F 5.. 150800

†Canadensis nana. Very dwarf; distinct and pretty

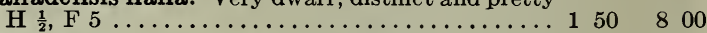

†Skinneri. Scarlet, handsome and distinct. H 3 to 4

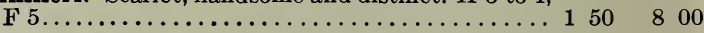

†Glandulosa. Splendid dwarf variety, with lovely blue and white flowers................. $150 \quad 800$

8

$\dagger$ †ætschaui. Large yellow flowers, with reddish spurs $150 \quad 800$ †Californica. Large orangeyellow flowers............ $150 \quad 800$

†Truncata. Scarlet and yellow; dwarf, very early..... $150 \quad 800$

†Alpina superba. Blue and white................ $150 \quad 800$

†vulgaris. Old-fashioned double Columbine......... 1258800

Six choice Aquilegias, in six varieties, for $75 c$., or 12 plants, in 12 varieties, for $\$ 1.50$

AJUGA reptans atropur-Perdoz. 100 purea. Large spikes of purplish blue flowers in May. Valuable plant for the rockery and for carpeting the ground in shady places where grass will not grow..................

ARENARIA Balearica. Creeping plant, with dense mosslike foliage; white flowers in spring; fine for rockwork. . 150

TARALIA. Splendid native foliage plants, growing 6 to 8 feet high; of striking effect

Cordata................ 200

Edulis .................... 200

Cachemirica.......... 200

ARABIS alpina. Forms a dense carpet, completely covered with pure white flowers in early spring. Fine for rockwork and edging ................ 150

ARTEMISIA Abrotanum. (Old Man, or Southernwood). Dark green, finely cut foliage; aromatic odor. 150

Absinthium (Wormwood)... 150

Stelleriana (Old Woman) Deeply cut silvery foliage; much used in carpet-bedding. $H 18$ in.......... 100

†Japonica, Queen Charlotte. Large semi-double Perdoz. 100 flowers of a lovely shade of pink............ \$1 $50 \quad \$ 800$

†Japonica, Lady Ardilaun. Pure white, broad, overlapping petals.

$150 \quad 900$

These charming Japanese Anemones are among the most beautiful things in cultivation. They are perfectly hardy, and in a strong, rich and heavy soil will grow 4 to 5 feet high. They are a mass of beautiful white or pink bloom from late summer until heavy frosts. They should be in every garden, and on large places should be planted by the hundred. Should be planted early in September or in the spring. They like a heavy soil and partial shade.

ANCHUSA “Dropmore Variety." A grand variety growing 4 to 5 feet high with lovely blue flowers throughout the season...........each, 25 cts.. 250

ANTHEMIS Kelwayi. Soft, clear yellow. $H 1 \frac{1}{2}, \mathrm{~F}$ 6 to 8

ANTHERICUM Liliastrum (St. Bruno's Lily) Pure white, fragrant, graceful, lily-like plant, preferring partial shade.................... 175
ARUNDO Donax. Splendid for making tropical-like groups; will grow 16 feet high in rich soil........

Donax macrophylla. An improved variety with broader leaves..............50 cts. each. .

Donax variegata. Striking variegated foliage. H

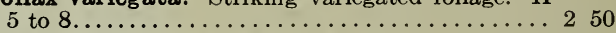

ARMERIA maritima splendens (Thrift or Sea Pink) 150 $\mathrm{H} 1 / 4, \mathrm{~F} 5$ to $7 \ldots \ldots \ldots \ldots \ldots \ldots \ldots \ldots \ldots \ldots \ldots$. 150

Dianthoides......................... 150

Formosa........................... 150

Cephalotes............................ 150 and distinct new variegated grass which should prove very attractive in the rock-garden....... 150

ASCLEPIAS tuberosa. Orange-scarlet; one of the showiest and finest hardy plants grown. $\mathrm{H} 1$ to 2 ,

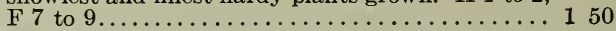
Incarnata. Rosy pink flowers: very desirable. $\mathrm{H}$ 2 to $3, \mathrm{~F} 7$ to $9 \ldots \ldots \ldots \ldots \ldots \ldots \ldots \ldots \ldots \ldots$
ARRHENATHERUM bulbosum variegata. A neat
1500

700 700

700

700

700

800 


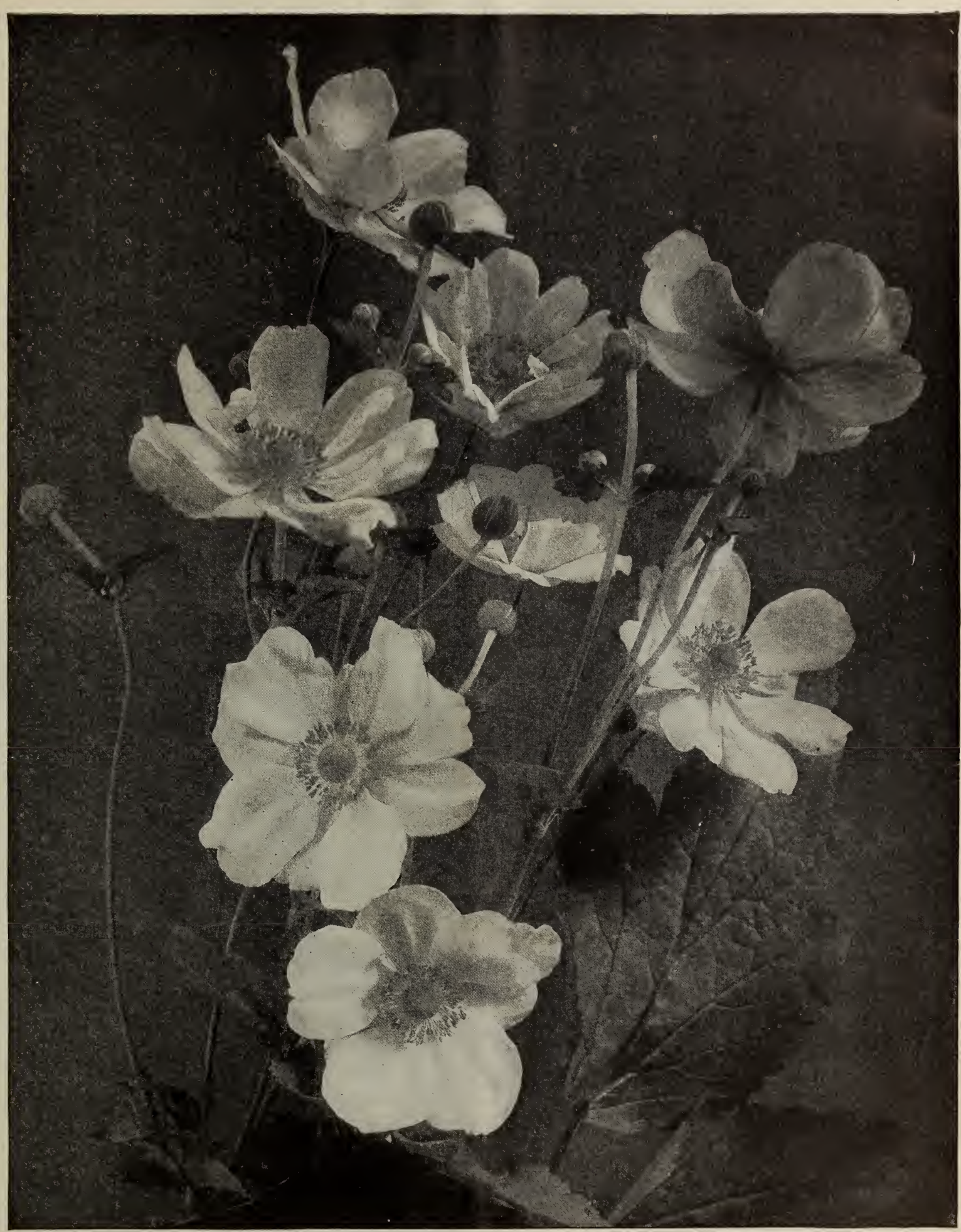

ANEMONE JAPONICA (see page 44) 


\section{HARDY HERBACEOUS PERENNIAL PLANTS, continued}

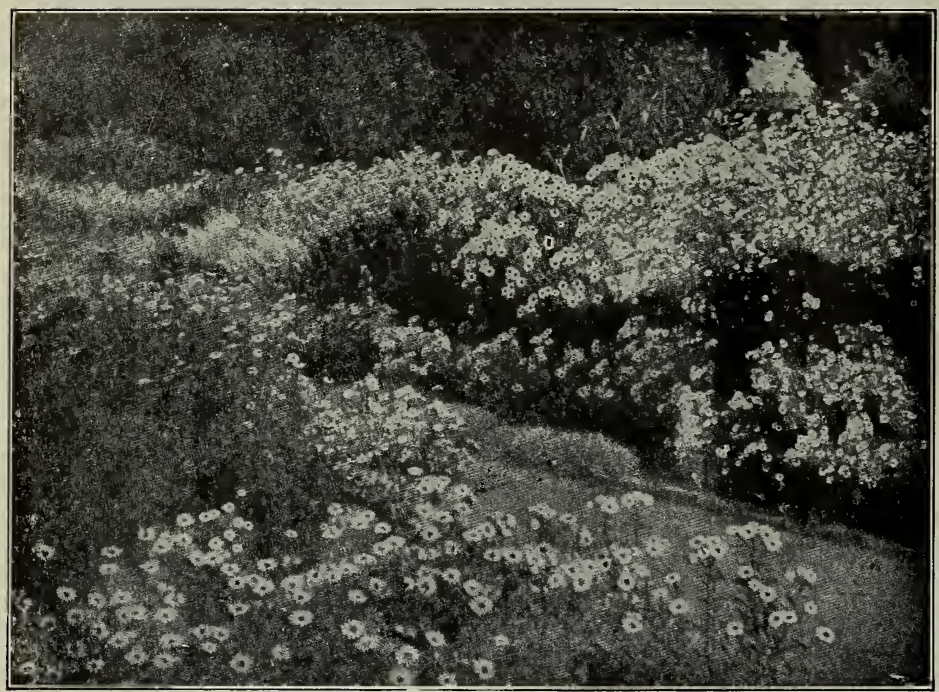

(1:rom "Wood and Garden")

Hardy Asters

ASTER Novæ-Angliæ rubra. The best of the Amer- Per doz. 100 ican "Hardy Asters"; very showy. H 3 to 4, F 9 to 10 $\$ 1 \quad 50 \quad \$ 800$

Alpinus. Very dwarf variety with large showy purplish flowers in May and June.

150

Alpinus alba. A variety of above.

150

BEAUTY OF TYMARDREATH. A beautiful new Michælmas Daisy; white flowers with golden dise changing to red.

250

Top Sawyer. Clear blue; very fine H 4 to $5, \mathrm{~F} 9{ }_{1} 50$

Turbinellus. Delicate mauve. $\mathrm{H} 2$ to $4, \mathrm{~F} 92250$

Tataricus. Large flowers and very late. $\mathrm{H} 5$ to 6 , F 9 to 10

150

Ptarmicoides. Dwarf, early-flowering, hardy Aste blooming in July and August. Its charming white flowers are produced in the greatest profusion. Distinct and good.

White Queen. White flowers. H 4, F $9 \ldots \ldots \ldots$

Trinervius. White, with purple and yellow disc H $3 \frac{1}{2}$ F 8 to 9

Grandiflorus. Distinct in character and flower very large flowers of a lovely violet-blue, and is the latest variety to bloom.

Coombe Fishacre. Fine flesh-colored native erect and graceful; $\mathrm{H} 3, \mathrm{~F} 8$ to 9 .

Robert Parker. Large sprays of beautiful lavenderblue flowers, with yellow center. H 4, F 9 . .

Novæ-Angliæ, Wm. Bowman. Large, rich rosy purple flowers, with deep golden bronze disc. Very showy. $\mathrm{H} 4$ to $5, \mathrm{~F} 8$ to $9 \ldots \ldots \ldots$ each, $15 \mathrm{cts}$.

Novæ-Angliæ, Mrs. J. F. Rayner. Large vivid crimson flowers, 2 inches in diameter; strong, erect grower. $\mathrm{H} 4$ to 5 , F 8 to 9

Novi-Belgii, Ella. Large, delicate mauve flowers, with golden center; profuse bloomer; extra fine. . 250

AUBRIETIA violacea. Valuable evergreen trailer $\mathrm{H} 1$ to 3 , F 4 to 5 .

APTISIA australis.

BELLIS perennis (Double Daisy). Assorted colors. $\mathrm{H} \frac{1}{2}, \mathrm{~F} 4$ to 5

100

BERGAMOT. See Monarda.

BLEEDING HEART. See Dicentra.

BELLIS perennis (English Daisy). Improved, largeflowered variety; white and pink.

BOCCONIA macrocarpa

Cordata. Large, broad, striking leaves; large plumes of white flowers; fine for subtropical effects. H 5 to $7, \mathrm{~F} 7$ to 8

Giralda. A handsome new variety with large silvery gray foliage and bold heads of milky whit flowers. 800 800 800 800 800 $150 \quad 1000$
BAPTISIA australis (False Indigo), Per doz. 100 Dark green, deeply cut foliage and spikes of dark blue flowers. $\mathrm{H} 2$ F 6 to $7 \ldots \ldots \ldots \ldots \ldots \ldots \ldots \ldots$

BOLTONIA latisquama. Light pinkish blue flowers; very lovely; blooms late in fall. Highly recommended. H 3 to $4 \ldots$.......................... tive. H 3 to 4 , F 9 to $10 \ldots \ldots \ldots$.

$150 \$ 1000$ crimson flowers; trailing habit; very showy......................

CALIMERIS incisafolla. A graceful little plant with finely cut foliage and the prettiest of all single white daisy flowers; blooms all summer and is distinct and fine

CAMPANULA (Bellflower). The Campanula genus is one of the largest and choicest. The varieties are all of elegant habit and should be represented in every garden.

Alliariæfolia. Graceful spikes of long, bell-shaped white flowers. H 3, F 7.. 150

Pyramidalis. Very showy, tall variety. H 4 to 5 , F $7 \ldots \ldots \ldots \ldots 150$

Pyramidalis alba. White flowers.

H 4 to 5 , F 7 . 150

Turbinata. Large, erect, blue flowers; fine............... $175 \quad 1200$

Turbinata alba. Charming white flowers. $\mathrm{H} \frac{1}{2}$ to $1, \mathrm{~F} 7$ to $8 \ldots \ldots \ldots \ldots \ldots \ldots \ldots$ $150 \quad 1000$ Medium (Canterbury Bells), One of the showiest and prettiest of garden plants; but, being only a biennial, dies after blooming. Should be planted in spring... $150 \quad \begin{array}{llll}50 & 10 & 00\end{array}$

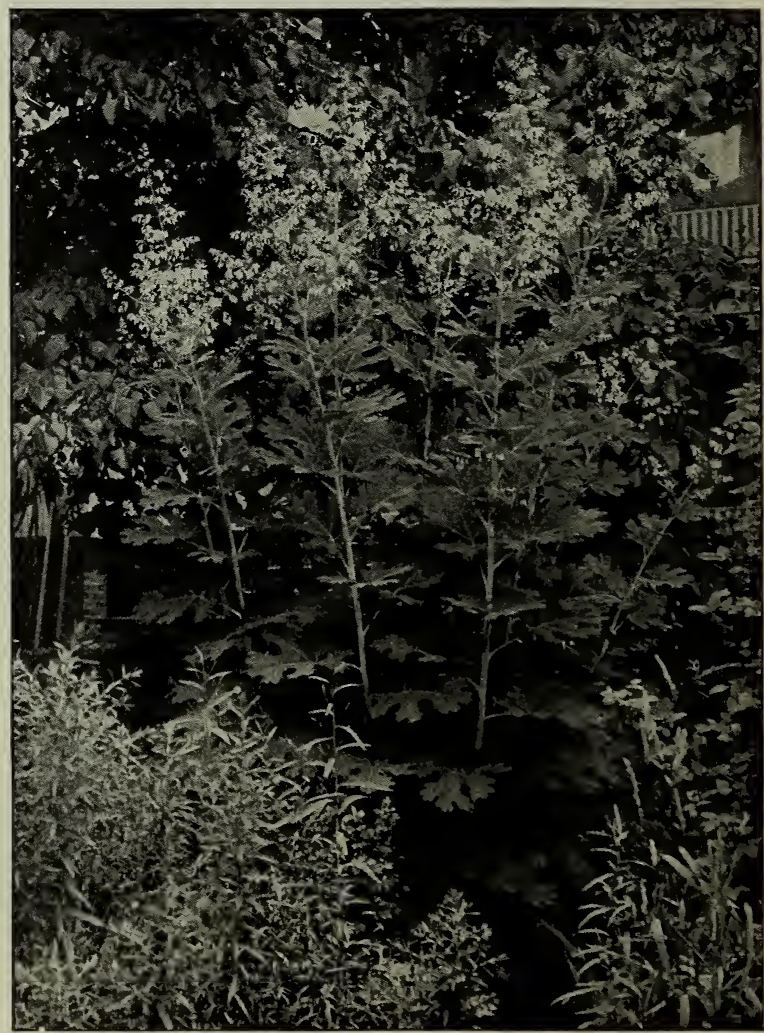

Bocconia 
HARDY HERBACEOUS PERENNIAL PLANTS, continued

Camp an u la persicifolia. Perdoz. 100 Large bluc flowers, almost as showy as Canterbury Bells. H 2, F $6 \ldots \ldots \ldots \$ 150$

Persicifolia alba. White flowers; a grand border plant. H 1 to 3, F $7 \ldots 150$

Grandiflora Mariesi. Large white and purplc flowers; desirable..

$150 \$ 1000$

Mariesi compacta nana. A new improved dwarf variety of great beauty; large white or purple flowers. ................ blue. H $3 / 4$, F 6 ........ $150 \quad 1000$

Macrantha. Large blue flowers; one of the best.. $150 \quad 1000$

Punctata. Strong, erect spikes, fine and showy; one of the best........ $125 \quad 800$

CANDYTURT. See Iberis.

CANTERBURY BELLS. See Campanula Medium.

CARDINAL FLOWER. See Lobelia.

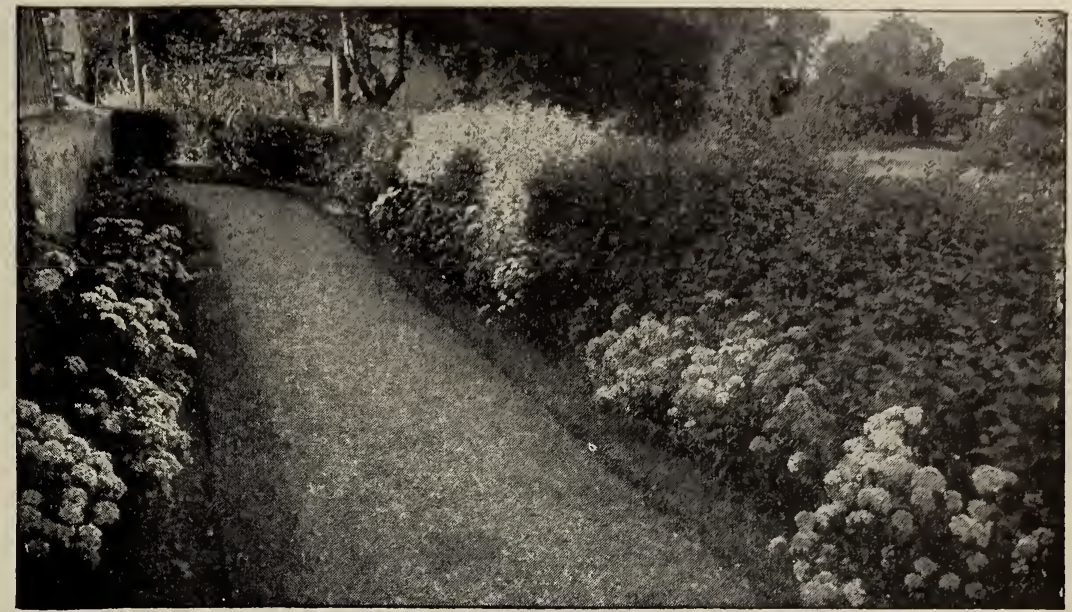

Hedge of Dianthus barbatus

CASSIA Marylandica. Handsome pinnate foliage and numerous racemes of showy yellow flowers; an extremely desirable plant of the easiest culture.

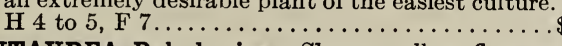

CENTAUREA Babylonica. Showy yellow flowers; suitable for planting in shrubberies and large

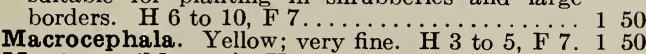

Montana (Mountain Knapweed). Blue flowers.

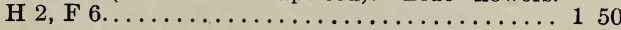

CERASTIUM Beibersteinei. Very dwarf plant, covered with small white flowers; very desirable for carpeting or edging borders and beds; silvery white foliage, which is very attractive throughout the season.......................... 125

CHRYSANTHEMUM, Hardy Pompon Varieties. $\mathrm{H} 2$ to $3, \mathrm{~F} 10$ to 11

Hardy Large-flowered Varieties. These and the preceding varieties are the old-fashioned Chrysanthemums that used to be in every garden. They are perfectly hardy, and make a brave show of color late in the fall, after all other flowers are gone. $\mathrm{H} 3$ to $4, \mathrm{~F} 10$ to $11 \ldots \ldots \ldots \ldots \ldots \ldots \ldots 150$

Latifolium. Similar to the Maximum but much better; one of the most satisfactory of hardy plants; highly recommended; fine for cutting. H 2, F 6 to $9 \ldots \ldots \ldots \ldots \ldots \ldots \ldots \ldots \ldots \ldots$. 150

Maximum. Large, single, daisy-like flowers.......... 125

Maximum flifera. A dwarf, improved form of

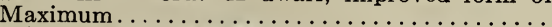

Maximum, Princess Henry. A variety with very large white flowers $\ldots \ldots \ldots \ldots \ldots \ldots \ldots \ldots \ldots 150$

Leucanthemum (Shasta Daisy). Advertised as a California Wonder...........10 cts. each.... 100

CLEMATIS recta. Large heads of purc white flowers. each, 25 cts... 250

Davidiana. This is an herbaceous plant instead of a climber, and has beautiful blue flowers and handsome foliage; very desirable............. 150

Integrifolia. Large purple flowers in great profusion in July and August................. 150

COREOPSIS grandiflora. An improved variety with large, bright yellow flowers; fine for cut-flowers; one of the best hardy plants in cultivation. $\mathrm{H} 2$ to $3, \mathrm{~F} 5$ to 7

verticillata. Masses of small golden yellow flowers, finely cut foliage. $\mathrm{H} 2$ to $3, \mathrm{~F} 7$ to $8 \ldots \ldots \ldots \ldots .150$

CORONILLA varia. Compact sheets of beautiful pink bloom. H $1, \mathrm{~F} 5$ to $10 \ldots \ldots \ldots \ldots \ldots \ldots 125$

CONVALLARIA majais (Lily-of-the-Valley). Pips . 40

800

800

1000

800

CRAMBE cordifolia. One of the finest large-leaved herbaceous plants; valuable where a striking and bold effect is required.........35 cts. each.. 350

CYPRIPEDIUM spectabile. The most beautiful hardy orchid, and one of the most lovely flowers in the world; does well in a shady location..... 350
DAY LILY, WHITE. See Funkia. Yellow. See Hemerocallis.

DELPHINIUMS, Chinense. Dark blue, smallflowered; elegant and distinct dwarf species..... Formosum. A splendid old hardy plant, with dark intense blue flowers. $\mathrm{H} 4$ to $5, \mathrm{~F} 6$ to 7

Formosum colestinum. New; light; of great beauty

DIANTHUS barbatus (Sweet William). Improved auricula-flowered.

Latifolius atrococcineus if. pi. (Everblooming Hybrid Sweet William). A beautiful summer bedding variety, producing masses of brilliant fiery crimson flowers throughout the entire season.

Scoticus fl. pl. (Double Scotch Pink). Desirable.

"Her Majesty." A fine hardy white Pink...

Plumarius, Pheasant's Eye (Hardy Pink)

Plumarius semperflorens. One of the most beautiful Pinks in cultivation; blooms all season. . .

Deltoides. A creeping Pink of great beauty

Juliette. White laced crimson.

†DICENTRA spectabilis (Bleeding Heart). H 1 to $2, \mathrm{~F} 4$

*Eximia. Beautiful fern-like foliage; blooms all summer. $\mathrm{H} 3 / 4$ to $1 \frac{1}{2}, \mathrm{~F} 4$ to 8 ...

DRACOCEPHALUM Ruyschiana. Dark violet-

blue; neat border plant. $\mathrm{H} 2, \mathrm{~F} 6 \ldots \ldots \ldots \ldots$
DICTAMNUS. The Dictamnus is one of the most satisfactory hardy plants in cultivation, both on account of splendid flowers and its rich, durable foliage.

Fraxinella. $\mathrm{H} 2, \mathrm{~F} 5$ to $7 \ldots \ldots \ldots \ldots \ldots \ldots \ldots 200$

Fraxinella alba. $\mathrm{H} 2, \mathrm{~F} 7$ to $8 \ldots \ldots \ldots \ldots \ldots \ldots 200$

†DIGITALIS purpurea (Foxglove). H 4 to 7, F 7 . †Gloxinæflora.

Maculata superba

Grandiflora.

Buxbaumii...

Per doz. 100

$\begin{array}{llll}50 & \$ 9 & 00\end{array}$

$150 \quad 1000$

125800

$150 \quad 800$

$\begin{array}{rrrr}1 & 25 & 8 & 00 \\ 1 & 50 & 10 & 00\end{array}$

$\begin{array}{llll}1 & 00 & 6 & 00\end{array}$

$150 \quad 1000$

150800

$\begin{array}{lll}50 & 1000\end{array}$

$\begin{array}{lll}75 & 1200\end{array}$

$\begin{array}{lll}75 \quad 1200 & 0\end{array}$

$150 \quad 1000$

DORONCUM plantagineum excelsum H 2 to 3250

ECHINOPS Ruthenicus. Showy thistle-like plants with globular heads of glaucus blue flowers.....2 200

EPILOBIUM angustifolium. Crimson flowers; suitable for naturalizing. $\mathrm{H} 3$ to $6, \mathrm{~F} 7 \ldots \ldots \ldots$.

ERIANTHUS Ravennæ. A splendid tall-growing grass suitable for tropical effects. H 8 to 12 , F 9 to 10 .

ER YNGIUM Ebeneum. (Sea Holly). Curious and beautiful plants.

ER YSIMUM pulchellum. Dwarf plant like a wall-

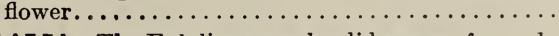

EULALIA. The Eulalias are splendid grasses for making beds and groups for tropical effects.

Japonica variegata. H 5 to 7

Japonica. H 5 to 7

Gracillima. Very graceful. $\mathrm{H} 5$ to 7 .

$\begin{array}{llll}1 & 25 \\ 1 & 25\end{array}$

125

125
1000

800
800

800

1500

50

600

$\begin{array}{ll}6 & 00 \\ 6 & 00\end{array}$ 


\section{HARDY HERBACEOUS PERENNIAL PLANTS, continued}

EUPHORBIA corollata. A choice native plant with Perdoz. 100 white flowers; largely used by florists for cutflowers............................ $\$ 150 \quad \$ 800$

EUPATORIUM purpureum. A splendid native plant, growing 6 to 10 feet high, with immense head of purplish pink flowers; fine for naturalizing along streams and ponds, and for planting among shrubbery. F 7 to 9 ...

EVENING PRIMROSE. See Enothera.

*FERNS. Best hardy varieties............... $150 \quad 1000$

FESTUCA glauca. A very dwarf grass with pretty blue foliage; fine for edging.............. 150

FOXGLOVE. See Digitalis.

*FUNKIA subcordata (White Day Lily). H $1 \frac{1}{2}$, F 5 to 8 .

*Variegata. Variegated foliage, blue flowers, $\dot{H} \ddot{1}$ F 5

*Corulea (Blue Day Lily). H $2 \frac{1}{2}, \mathrm{~F} 7 \ldots \ldots \ldots \ldots$ account of its splendid foliage. $\mathrm{H} 2$ to $3, \mathrm{~F} 7$ to 8 . 2

*Aurea maculata. Young foliage in early spring is of a bright yellow color.

* Marginata albo variegata. A very distinct variegated variety

*Aoki. Large glaucus green leaves..............

Fortunei. Large glaucous green leaves; flowers mauve...

GAILIARDIA Hardy varieties. (See page 36).....

GILLENIA trifoliata. A strong-growing plant, suitable for the border or shrubbery; handsome foliage and numerous white flowers tinged pink. H 3, F 7. 200

GEUM Coccineum. Pretty border plants, growing 18 inches high and producing brilliant scarlet flowers throughout the summer.

Atrosanguineum. Orange-scarlet

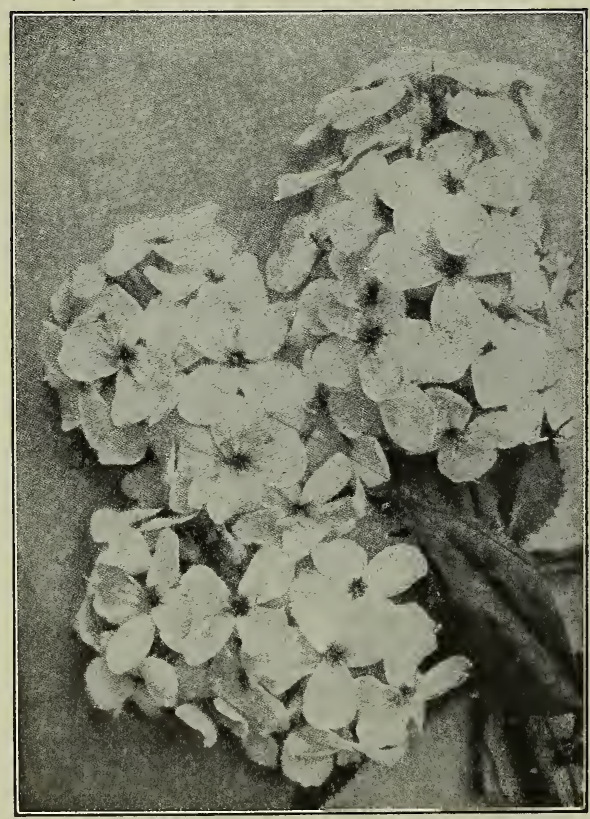

Hesperis matronalis

Per doz.

GENTIANA Adrewsii (Blue Gentian). Pretty native species with blue flowers. H $1 \frac{1}{2}, \mathrm{~F} 9 \ldots \ldots \ldots \ldots \$ 200$

GYPSOPHILA paniculata (Baby's Breath). When in bloom in August and September it forms a symmetrical mass, 2 to 3 feet in height and as much through, of minute white flowers having a beautiful gauze-like appearance.

GLOBULARIA Tricosantha (Globe Daisy). Light blue flower. $\mathrm{H} \frac{1}{2}$ to $\frac{3}{4}, \mathrm{~F} 5$.
HELIANTHUS. The hardy Sunflowers are among the Per doz. 100 most desirable of hardy plants. They are freeflowering, have a long season of bloom, are very decorative in the garden, and are fine for cutting. All have bright yellow flowers.

Tuberosa (Jerusalem Artichoke). Very decorative; grows 12 feet high; also a desirable vegetable... $\$ \begin{array}{lllll} & 00 & \$ 6 & 00\end{array}$ Lætiflorus. The best, free-flowering, single yellow flowers; fine for cutting. H 4 to $5, \mathrm{~F} 7$ to $8 \ldots \ldots$.

Maximiliana. Tall and very late; one of the most
stately and elegant hardy plants in cultivation; best Sunflower to bloom in the fall. $\mathrm{H} 7$ to 9 , F 10 to 11 .

Miss Mellish. Very large duplex flowers of exquisite shape and bright orange-yellow, freely produced during August and September. Grand for cutting. H $5 \ldots \ldots \ldots \ldots \ldots \ldots \ldots \ldots \ldots$

Orgyalis. A verv striking, tall Sunflower. $\mathrm{H}$ 5 to $6, \mathrm{~F} 6$ to $10 \ldots \ldots \ldots \ldots \ldots \ldots \ldots \ldots \ldots \ldots \ldots \ldots \ldots$

Giganteus. Pale yellow flowers, 3 inches across; very elegant. $\mathrm{H} 4$ to $5, \mathrm{~F} 8$ to $9 \ldots \ldots \ldots \ldots \ldots 150$

Buttaris............................. 150

Wolley Dod. The best of the September flowering varieties; deep yellow flowers; distinct and fine.. 150

HELIANTHEMUM mutabile (Sun Rose). Charming dwarf evergreen plants with pink and white flowers. $\mathrm{H} \frac{1}{2}, \mathrm{~F} 5$ to $6 \ldots \ldots \ldots \ldots \ldots \ldots \ldots \ldots \ldots \ldots \ldots \ldots$ HELENIUM Hoopesii. Bright orange flowers. $\mathrm{H} 2$ to $3, \mathrm{~F} 7$ to $8 \ldots \ldots \ldots \ldots$

Autumnale superbum. An improved variety of great beauty........................... 200

HELIOPSIS Pitcheriana. Similar to the hardy Sunflower, but blooming during a much longer season. H 3 to $6, \mathrm{~F} 8$ to $10 \ldots \ldots \ldots \ldots$. . . . . . . . . the best of the Heliopsis. H $3, F 7$ to $9 \ldots \ldots, 150$

HELLEBORUS niger (Christmas Rose) each, $35 \mathrm{cts} .350$ HEMEROCALLIS Flava (Lemon Day Lily). H 2 to $3, \mathrm{~F} 6$ to 7

Florham. Splendid new large-flowering sort; bright yellow flowers..................... 250 Fulva (Orange Day Lily). H 2 to $3, \mathrm{~F} 6$ to $7 \ldots \ldots 12$ Fulva flore pleno. Double................ 175 Graminea. Bright yellow; one of the best........ 150

Dumortieri. $H 1 \frac{1}{2}$, F 6 to $7 \ldots \ldots \ldots \ldots \ldots \ldots 150$

Aurantiaca. Large orange-yellow flower......... 250

Aurantiaca major. New and very beautiful. Needs protection in winter............. 250

Thunbergi. Bright yellow. H $3, \mathrm{~F} 7$ to 8 ...... 150

Sieboldii. Clear, deep bright yellow. H 3, F 5 to 6.175 HERACLEUM giganteum (Giant Parsnip). A remarkable foliage plant........25 cts. each.. 250 HESPERIS matronalis, Purple (Sweet Rocket). $\mathrm{H} 2$ to 3 , F 6 to 9. Matronalis, white...................... 125

HEUCHERA sanguinea. Very choice, graceful dwarf plant with lovely crimson flowers; fine for cutting. $\mathrm{H} \frac{3}{4}$ to $1 \frac{1}{2}, \mathrm{~F} 7$ to $9 \ldots \ldots \ldots \ldots \ldots 150$

Rain of Fire. A new and greatly improved variety. 200 HIERACIUM Aurantiacum. A low-growing, rapidspreading plant adapted for dry sandy spots or covering steep banks; orange-red flowers....... 150

HIBISCUS Moscheutos. Bright pink.......... 150

Moscheutos, "Crimson Eye." White. H 3 to 6 ,

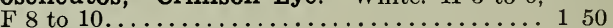

HOLLYHOCKS, Best Double........... 150

Best Single........................... 125

HONESTY. See Lunaria.

HYACINTHUS candicans. Showy white flowers, blooming in summer; easiest culture......... 50

IBERIS (Candytuft) corifolia. Large snow-white

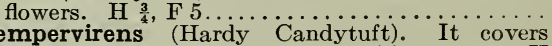
the ground with a mat of pure white flowers. H $\frac{3}{4}$ to $1, \mathrm{~F} 4$ to $5 \ldots \ldots \ldots \ldots \ldots \ldots \ldots \ldots \ldots \ldots \ldots \ldots$

Sempervirens nana. Improved dwarf variety..... 125 Sempervirens, "Queen of Italy." A new dwarf variety with violet flowers; very pretty......... 125

$\begin{array}{rr}800 \\ 8 & 00\end{array}$

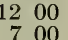

700 IS Kæmpferi (Japanese Iris). See page 26.

Pseudo-acorus variegata. Foliage beautifully variegated; flowers rich yellow: suitable for marshes and water-courses. $\mathrm{H} 3, \mathrm{~F} 5$ to $6 \ldots \ldots, 100$
800 
HARDY HERBACEOUS PERENNIAL PLANTS, continued

Iris Germanica (German Iris), 25 choice named Per doz. 100

varieties. $\mathrm{H} 2$ to $3, \mathrm{~F} 6$

Germanica, Mixed Varieties

Sibirica sanguinea. Bright blue flowers. $\mathrm{H} 3$ to $4, \mathrm{~F} 6$.

Sibirica alba. White.

Florentina (Orris Root). Very large white fragrant flowers. $\mathrm{H} 2, \mathrm{~F} 5$ to 6

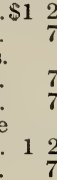

INULA Helenium. Free-flowering border plants with yellow flowers. H $2, \mathrm{~F} 6$ to 8.150

INCARVILLEA Delavayi (Hardy Gloxiana). Large gloxinia-like rose-colored flowers that last a long time in perfection; should be protected by a covering of leaves in the winter.

$\begin{array}{rrrr}25 & \$ 8 & 00 \\ 75 & 5 & 00 \\ 75 & & 5 & 00 \\ 75 & & 5 & 00 \\ 25 & & & \\ 75 & & 5 & 00\end{array}$

LATHYRUS latifolius splendens. Bright pink..................... Latifolius albus (White Everlasting Pea).
These Everlasting Peas are but little known in this country, but are great favorites in England. They are extremely showy and fine..........25 cts. each.. 250

IAVENDER. The well-known garden herb... 100

IIATRIS pycnostachya. Striking hardy summer-blooming plant, with great rocket-like spikes of purple flowers. H 3 to $5, F 6$ to $9 \ldots \ldots \ldots \ldots \ldots \ldots \ldots \ldots \ldots$

IINUM perenne (Flax). H $1 \frac{1}{2}, \mathrm{~F} 6$ to $8 \ldots \ldots 125$

Perenne album.................. 125

Perenne roseum.

105

IOBELIA cardinalis. Native plant, with intensely brilliant cardinal flowers. $\mathrm{H} 2$ to $3, \mathrm{~F} 7$ to $9 \ldots \ldots \ldots \ldots \ldots \ldots \ldots \ldots \ldots \ldots 150$

IUNARIA biennis (Honesty) ........... 125

IUPINUS polyphyllus. An extremely showy plant with large spikes of blue flowers; very effective but does better north of here, as it is partial to a cool climate. H $3, F 5$ to 6.150

I YCHNIS viscaria splendens ......... 125

Chalcedonica. Dense heads of brilliant scarlet flowers; one of the best border plants. H $1 \frac{1}{2}$ to $3, \mathrm{~F} 5$ to $8 \ldots \ldots \ldots \ldots$

Chalcedonica flore pleno. A fine double

variety; fine for cutting........ 150

I YTHRUM superbum roseum. Very showy; spl indid for banks of streams and ponds.

$\mathrm{H} 3$ to $5, \mathrm{~F} 7$ to $8 \ldots \ldots \ldots \ldots \ldots \ldots \ldots \ldots$ 1 $50 \quad 800$

I YSIMACHIA nummularia aurea (Golden Per doz. 100 Moneywort). Fine for carpeting..........\$1 25 \$5 00

Clethroides (Loosestrife). Semi-aquatic, with white flowers. H 2 to $3, \mathrm{~F} 7$ to $9 \ldots \ldots \ldots \ldots \ldots 150$

Punctata. Showy yellow flowers. H $1 \frac{1}{2}$ to $2, \ldots$ F 6.125

MERTENSIA Virginica. A lovely blue flower, blooming in early spring. H $2, \mathrm{~F} 4 \ldots \ldots \ldots \ldots \ldots 150$

* MONARDA didyma (Bergamot). Very showy crimson flowers. H $2, \mathrm{~F} 7$ to $9 \ldots \ldots \ldots \ldots \ldots \ldots \ldots \ldots, 125$

*Didyma rosea.

* Fistulosa (Wild Bergamot). Mixed colors. $\mathrm{H} 2$ to 4, F 6 to 8 . 100

MONTBRETIA. Hardy bulbous plants, with spikes of flowers like a miniature Gladiolus; they may be treated the same as a Gladiolus and taken up every fall or allowed to remain in the ground and protected with a covering of leaves. They are very attractive and desirable for cut-flowers.

Aurea. Fine golden yellow.

Drap d'Or. Orange-red center.

Eclatante. Free-flowering red.

Eldorado. Reddish yellow.

Brilliant. Scarlet

Crocosmæflora. Deep golden orange

Rayon d'Or. Fine yellow and brown.

MAIVA moschata rosea. This lovely Mallow blooms profusely in June and July, and grows 18 to 24 inches high. The flowers are rosecolored; 2 inches across................ 150

Moschata alba. Same as above with white flowers 150

MYOSOTIS palustris semperflorens (Water Forget-Me-Not). Splendid for naturalizing on edge of ponds and streams; also for beds and borders. 125

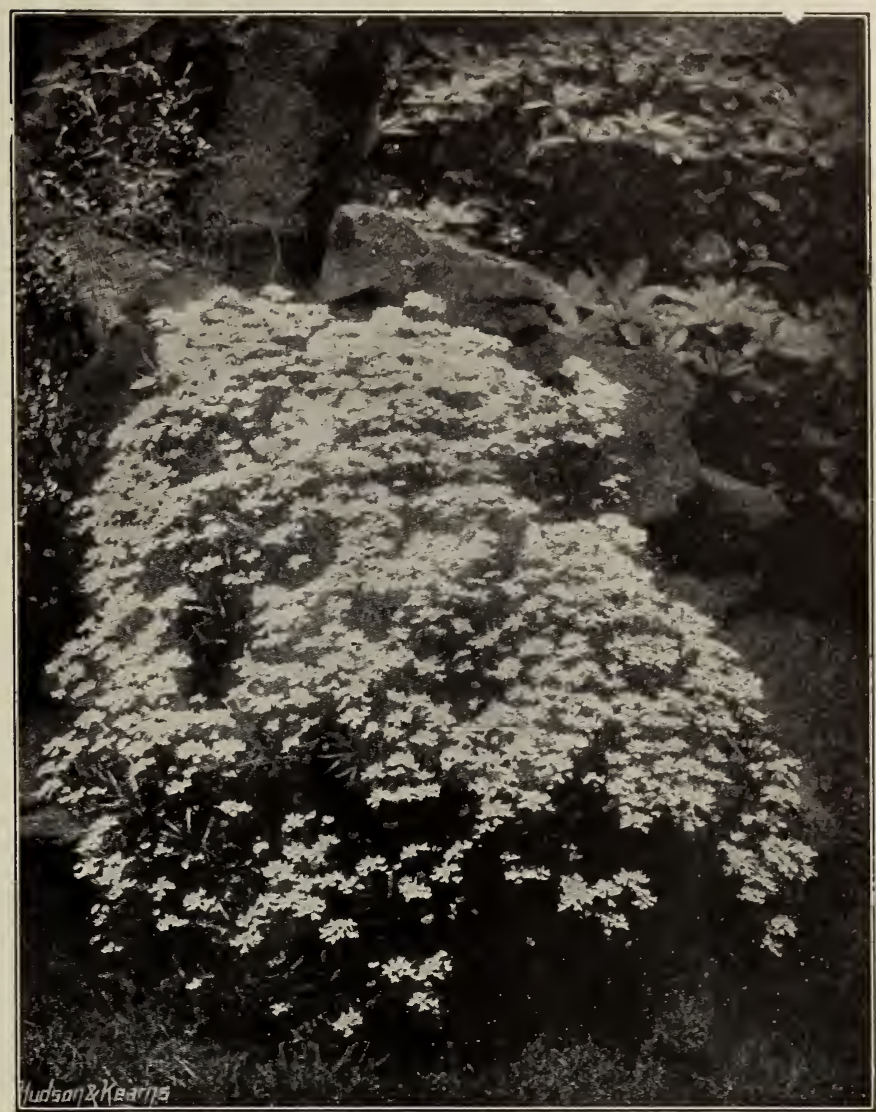

A Colony of Candytuft (Iberis) See page 48

OSNOTHERA (Evening Primrose). The Evening Perdoz. 100 Primrose is desirable and striking, and very effective in the garden on moonlight nights.

Splendens. A splendid dwarf variety, blooming in the daytime.

Missouriensis. $\dot{\mathrm{H}} \frac{i}{2}, \overrightarrow{\mathrm{F}} 6$ to 8 . $\$ 125 \$ 800$

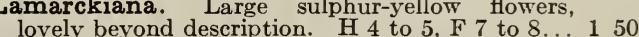

ONOPORDON Acanthium (Scotch Thistle). Noble plant, with striking foliage and showy purple flowers

PANSIES, Best Strain. Plants for spring bedding.

PAPAVER orientale (Great Oriental Poppy). Splendid $\mathrm{H} 3, \mathrm{~F} 6$.

PARDANTHUS Chinensis (Blackberry Lily)........
PENTSTEMON barbatus Torreyi. Brilliant crim-

600
son and orange flowers in July; one of the best hardy plants. H 3 to 5 .............

Digitalis. Showy spikes of pure white flowers.

PEONIES, Good Varieties. Mixed

Named Varieties......25 cts. to $\$ 1$ each; $\$ 2.50$ to 1000

PHIOX. The Creeping Phlox are among the most charming of hardy plants. They cover the ground with a mat of green at all times, and during the month of May make a most beautiful carpet of white or pink flowers. (See page 41.)

Best Perennial Named Varieties. Clumps from open ground; a fine collection.

*PHLOX divaricata. A beautiful native Phlox, with purple flowers. H 1, F 5 .

Carolina. A rare native variety with bright pink flowers; extremely desirable for spring bedding.. 150

PHYSOSTEGIA Virginica. Erect spikes of pretty pink flowers. $\mathrm{H} 1 \frac{1}{2}$ to $2 \frac{1}{2}$

virginica alba. A beautiful white variety. $\mathrm{H} 2$ to $3, \mathrm{~F} 7$ to 8 . 


\section{HARDY HERBACEOUS PERENNIAL PLANTS, continued}

PINK. See Dianthus.

Per doz. 100

PLANTAIN LILY. See Funkia.

PLUME POPPY. See Bocconia.

PLUMBAGO Larpentæ. A dwarf plant covering the ground completely with its foliage. In September it is a mass of beautiful deep blue flowers, which gradually change to violet.............

POLYGONUM cuspidatum (Giant Knotweed). Grows to 12 feet high; makes a splendid group for tropical effect.

PRIMULA vulgaris (English Hardy Primrose). H to $\frac{3}{4}, \mathrm{~F} 4$ to 5 .

*Veris (Polyanthus). H $\frac{i}{2}$ to $\frac{3}{4}, \mathrm{~F} 5$ to 6 .

Japonica. Beautiful and desirable variety.

Auricula

PYRETHRUM, Double Varieties.

Single Varieties. The Single Pyrethrums are among the loveliest hardy flowers grown. They are splendid for beds and borders, and nothing can be finer for cutting. Their single, daisy-like flowers, of all colors, are produced in the greatest profusion early in the spring and again in the fall.

RHEUM officinale (Chinese Rhubarb). The immense leaves of this noble foliage plant produce a bold and striking effect. Robinson says this is the most effective foliage plant introduced for many years. .25 cts. each. .

Collinianum. Like the above, but foliage more deeply cut; splendid. . . . ....40 cts. each.... Emodi. Grows 5 feet high; wrinkled-leaved, with
red veins; very effective........40 cts. each. 400

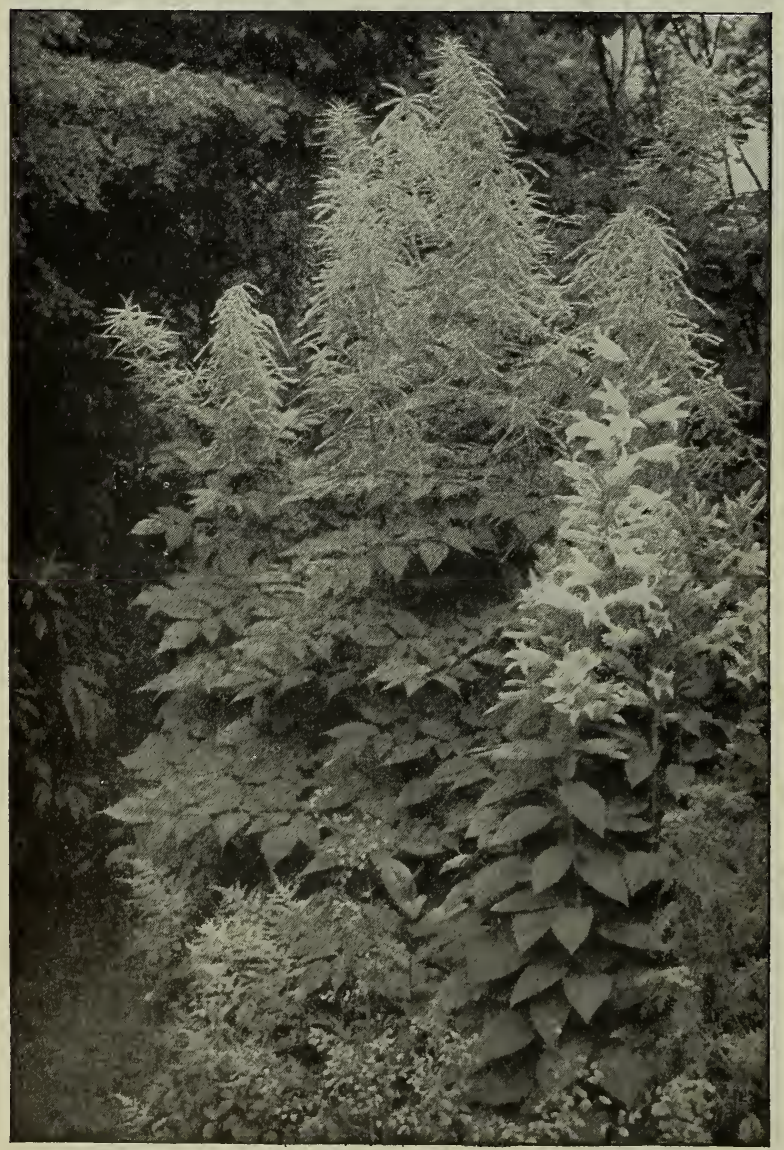

Spiræa Aruncus

\section{$\begin{array}{llll}1 & 50 & 6 & 00\end{array}$}

$\begin{array}{llll}1 & 00 & 6 & 00\end{array}$

175

150

$\begin{array}{llll}2 & 50 & 18 & 00\end{array}$

$175 \quad 1000$ 250 00

Rheum Tanghuticum. Has fine foliage and is of Per doz. 100 rapid growth..............4 40 cts. each. .\$4 00

Giganteum. A tall, vigorous variety of striking

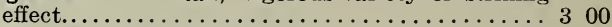

RANUNCULUS acris fl. pl. (Bachelor's Buttons). A showy border plant with double yellow flowers

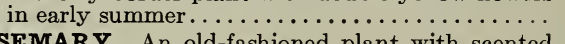
150

ROSEMARY. An old-fashioned plant with scented foliage........................ 150

RUDBECKIA speciosa. Native. One of the very best border plants in cultivation. A group of "Golden Glow" surrounded by this variety makes a splendid effect. H 2 to 3 , F 7 to 9 . 
HARDY HERBACEOUS PERENNIAL PLANTS, continued

THERMOPSIS Caroliniana. Showy plant, with Per doz. 100 attractive yellow flowers.............. 50

*TIARELLA cordifolia (Foam Flower). A most charming dwarf spring-flowering plant, with beautiful white flowers and lovely foliage....... 150

*TRILLIUM grandiflorum

$35 \$ 2 \quad 50$

*Erectum album..................... $\begin{array}{ll}35 & 50\end{array}$

TRITOMA uvaria grandiflora (Red-hot Poker). Needs protection; a striking fall-flowering plant. $\mathrm{H} 3$ to $4, \mathrm{~F} 9$ to $11 \ldots . . . . .$. Pfitzerii (Flame Flower, or Torch Lily). This new Tritoma is undoubtedly one of the most valuable introductions of recent years. Tritoma uraria, or "Red-hot Poker" plant, is highly prized on account of its picturesque appearance and its blooming so late in the fall after almost everything else is gone. This new variety is a great improvement in every respect. The flowers are much more refined and beautiful, and are produced in the greatest profusion from early summer until late fall, coming into bloom at least two months before the older variety. It is equally desirable for garden effect or for cut-flowers, and is decidedly unique.....................each, 15 cts... $150 \quad 1000$

TRADESCANTIA Virginica (Spiderwort). Produces a succession of purple flowers all summer.. 125

TUNICA saxifraga. A pretty tufted plant with light pink flowers, produced all summer; useful either for the rockery or the border............... 150

$150 \quad 1000$

UNIFOLIA latifolia. A very useful ornamental grass........................ 150

VERBASCUM nigrum. Yellow flowers in long spikes ; dwarfed habit........20 cts. each. . 200

olympicum. Bright yellow flowers; large woolly foliage; stately.............25 cts. each. 250
Verbascum phœniceum. Secdlings; crimson-rose, Per doz. 100 lilac and white; large and showy...30 ets. each. .\$3 00

Pannosum. Sulphur-yellow flowers; new species, with white foliage............35 ets. each.. 300

VERBENA venosa. A hardy Verbena; very extensively used in England for bedding. It grows about 18 inches high, but pegged down will cover the ground with heads of lovely purple-violct flowers throughout the scason. Not quite hardy, except on thoroughly well-drained soils.

$125 \$ 800$

VERONICA longifolia. Spikes of dcep bluish purple flowers; very handsome. H 2, F 8 to $9 \ldots \ldots \ldots$.

Spicata. Violet-blue flowers in long spikes; dwarf habit.

Rupestris 200

Amethystina

150

$\begin{array}{lll}1 & 25 \\ 1 & 50\end{array}$

VINCA corulea. The well-known hardy Myrtle; fine for carpeting under trees where grass will not grow........................... 125

VIOLA pedata (Bird's-foot Violet). A beautiful native sort.

Pedata bicolor. Deep purple flowers............ 125

800

Cornuta. Flowers almost as large as a Pansy. This is the most desirable of hardy plants. Blooms continuously all season; blue flowers...........

WAHLENBERGIA grandiflora

$\begin{array}{llll}1 & 50 & 10 & 00\end{array}$

$\begin{array}{llllll} & \end{array}$

Grandiflora alba...................... $175 \quad 1200$

YUCCA filamentosa (Spanish Bayonet). Fine, strong plants; a stately decorative plant, with immense spikes of large white flowers; fine for the garden or lawn............................................ Soap Plant.

Angustifolia.

\section{ORNAMENTAL FLOWERING SHRUBS}

Our stock of shrubs is unsurpassed in quality, but our prices will be found much lower than those made by most nurserymen. As a rule, shrubs are much more effective when planted in masses, and our low prices permit them to be used freely in this way. For a guide in planting, we have indicated the size the shrubs will eventually be, as follows: " $\mathrm{H} 3-4$, S $3-4$ June" which means "Height 3 to 4 feet, spread 3 to 4 feet, flowers in June." The sizes given can only be approximate as the size shrubs attain varies considerably with soils and climate.

Shrubs marked * can be grown in partial shade, but they will also thrive in full exposure to the sun.

\section{SPECIAL OFFER OF SHRUBS}

We want to encourage the planting of shrubs. To be effective they should be planted in masses, but when dealers or nurserymen ask fifty cents each for easily grown shrubs there is not much encouragement to plant them freely. We have made arrangements by which we can supply our customers with well-grown shrubs in the best varieties at the extremely low prices quoted below, but in every instance the selection of varieties must be left to us. But in ordering, if it is stated that certain shrubs are not wanted they will not be sent. We guarantee these shrubs to be satisfactory in both quality and variety. We can not give in advance of filling the order a list of varieties contained in these collections.
SPECIAL OFFER A- 50 shrubs in fine assortment of $\underset{\text { “ }}{15}$
$\$ 700$

ALMOND. Dwarf Double-flowering Pink. Each Per doz. 100

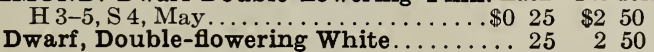

ALTHEA Buist's Variegated. Exceptionally fine for hedging purposes, as well as for producing marked contrasts in groups of mixed shrubbery. H 8-10, S 4-6, August and September............. 25

Double. Fine distinct named varieties....... 20

Single Dwarf White. Pure snowwhite; fine H 5-7. ......................

Seedlings. Mixed colors, single and semi-

Jeanne d'Arc. A new perfectly double, pure white flower, and a great a cquisition. It supersedes all the so-called double white varieties, being entirely immaculate............
Single-flowered Varieties. In white, blue and pink; very lovely and desirable......... 20

AMELANCHIER Canadensis (Juneberry)... H 12-15, S 12, April, May.............. 20

Botryapium. H 8-10, S 6-8, May......... 20

AMORPHA fruticosa. (False Indigo). H 6-

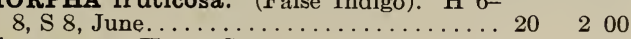

Canescens. H $2-3, \mathrm{~S} 2$, June............... $20 \quad 200$
ARALIA Japonica. A distinct and most Each Per doz. beautiful tall shrub with palm-like leaves and large heads of white flowers in August. H 8-12, S 5 .

Pentaphylla. A shrub little known but very desirable. The effect of the luxuriant glossy foliage on the arching branches is very beautiful. H $5-7$, S $5-6 \ldots \ldots \ldots \ldots \ldots \ldots \ldots 25$

AZALEAS. Should always be planted in the spring or early in September. $\mathrm{H} 4-6, \mathrm{~S} 4$, April-May

*Arborescens. A strong-growing native species, with very fragrant rose-colored flowers. 12 to 18 inches; fine plants........... 50

*Calendulacea. A splendid native Azalea. 36 to 48 inches; fine ................ $150 \quad 1500$

*Ghent. 15 inches................... 251200

Mollis. 8 to 12 inches..................... $35 \quad 3 \quad 50 \quad 2500$

Mollis. 12 to 18 inches; with bloom buds; splendid plants..................... 60

*Nudiflora. A native species, with fragrant pink flowers...................... 50

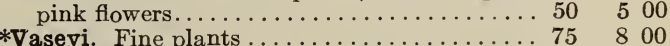

ANDROMEDA mariana. Small shrub with lovely pinkish white flowers. H $2-4$, S $3 \ldots 30$
100

$250 \$ 1600$

650

800

300 


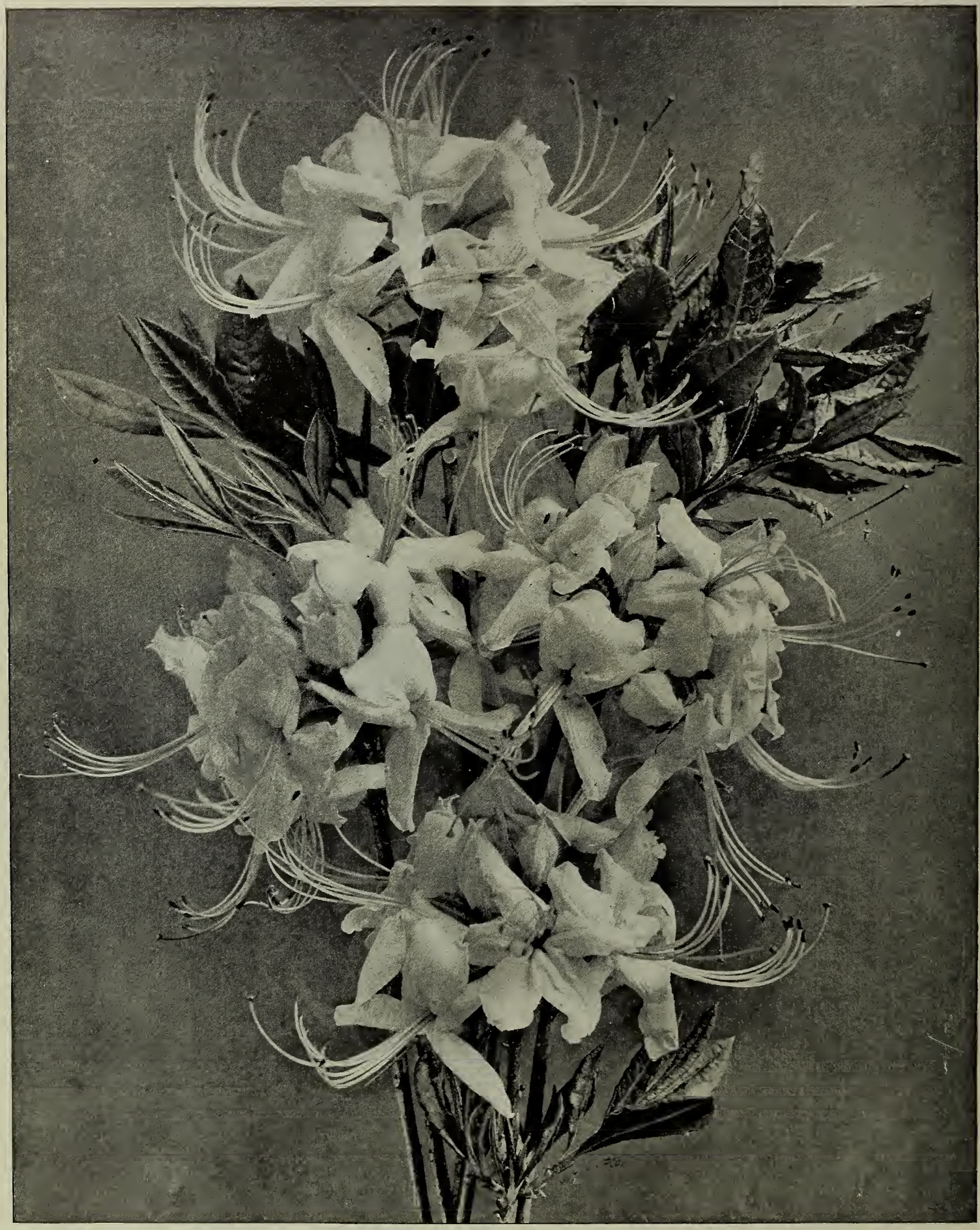

AZALEA CALENDULACEA (see page 51)

This, and in fact all of our native Azaleas, are very beautiful and desirable for the lawn, garden and for naturalizing They are perfectly hardy and of the easiest culture 


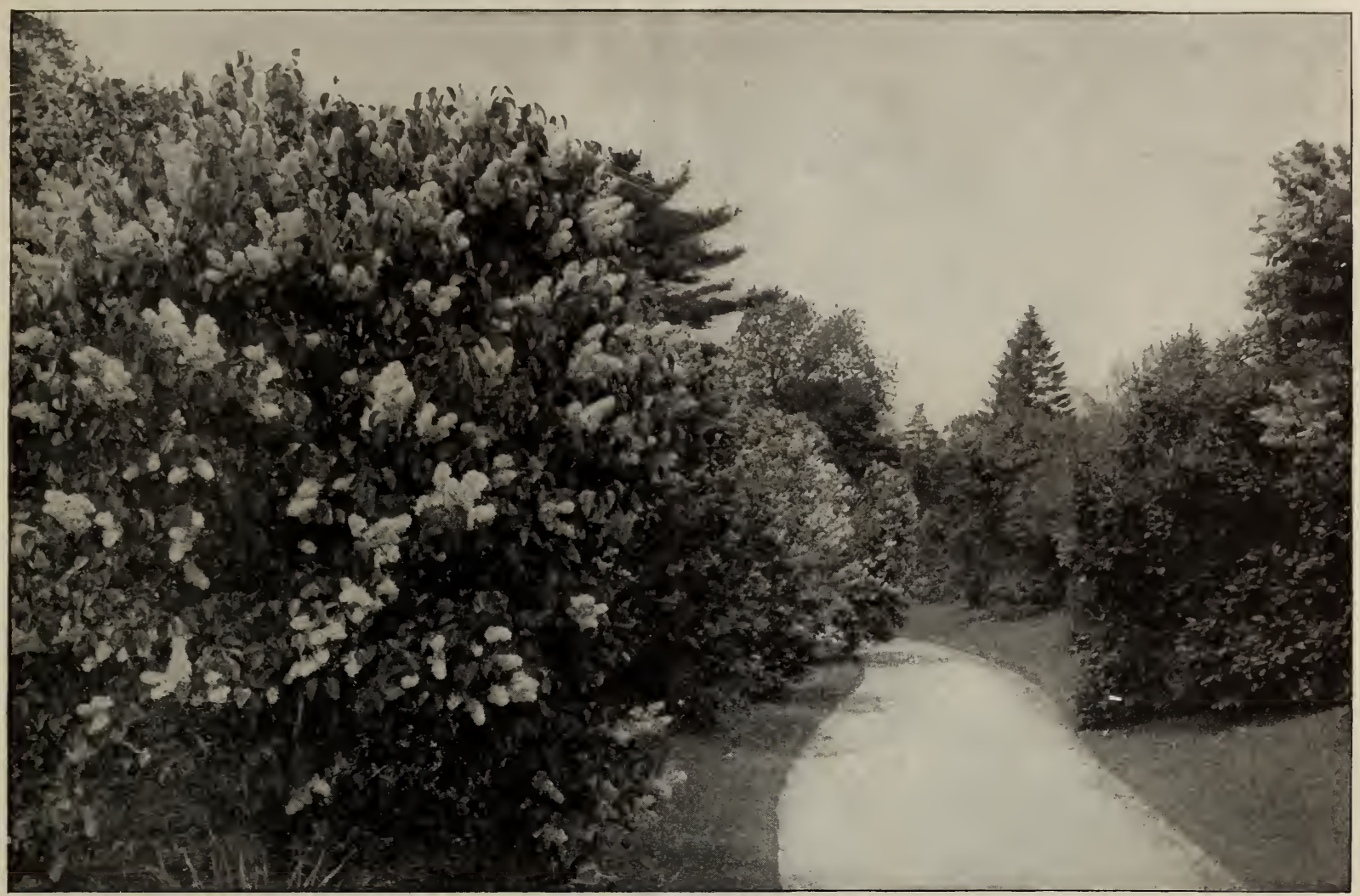

An attractive walk bordered with White Lilacs

ORNAMENTAL FLOWERING SHRUBS, continued

Each Per doz. 100

BERBERIS Sieboldi. H 5-6, S 4-5......\$0 20 \$2 00

*Japonica. Similar to Thunbergii, but more vigorous in habit........................

*Thunbergii (Japanese Barberry). One of the account of its habit, foliage and fruit; fine

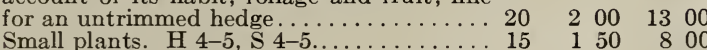

*Vulgaris (European Barberry). A magnificent shrub when it attains its full development; long racemes of yellow flowers in May followed by orange-scarlet berries which last all winter. H 6-8, S 6-8..............

* Vulgaris purpurea (Purple Barberry). H 56 , S $5-6 \ldots \ldots \ldots \ldots \ldots \ldots \ldots \ldots \ldots \ldots \ldots \ldots \ldots$. summer-flowering shrubs. In this climate the tops usually kill to the ground in the winter, but the roots are perfectly hardy. A vigorous new growth, which flowers free$\mathrm{ly}$, is produced every season. H 4-5, S 4-5.

Lindleyana. Violet-purple flowers in arching racemes 6 to 8 inches long.............
ariabilis. Lilac flowers produced in dense

$\nabla$ ariabilis. Lilac flowers produced in dense terminal panicles 4 to 6 inches long.......

CALYCANTHUS floridus (Sweet-scented

ARAGANA arborescens (Siberian Pea). Pale yellow pea-shaped flowers. H 8-10, $\mathrm{S} 8$, May, June......................

CAR YOPTERIS Mastacanthus (Blue Spirea) Not very hardy. H $2-3, \mathrm{~S} 2-3 \ldots \ldots \ldots \ldots 30 \quad 300$

CASSIA Marylandica (Wild Senna). Peashaped yellow flowers. H $3-4$, S $4-5 \ldots \ldots .15 \quad 125$

CEANOTHUS Americanus (Jersey Tea) Sweet-scented white flowers. H 2-3, S 3 . July-September.................... 20
CEPHALANTH US Occidentalis (Button Each Per doz. Bush). Curious round balls of white flowers in July. H 6-8, \$ 6 . . . . . . \$0 $20 \quad \$ 200$

CERCIS Japonica (Japanese Red Bud or Judas) Very showy pink flowers before the leaves appear in April. H 4-5, S 4-5........ $30 \quad 300$

CHIONANTHUS Virginica (White Fringe). H 10-12, S 6-8, May, June........... 40400

CLETHRA alnifolia (Sweet Pepper). A splendid summer-blooming shrub, with delicious white sweet-scented flowers. H $3-5, \mathrm{~S} 4$, July-September.......................
UTEA arborescens (Bladder Senna).

COLUTEA arborescens (Bladder Senna). Rapid growth. H 7-8, S 6-8.......... valuable shrubs on account of their easy growth, luxuriant foliage, bright-colored bark and showy fruits. Fine for massed and water-side planting.

*Alba, or Sibirica (Red-twigged Dogwood). Fruit bluish white $\mathrm{H}$ 6-8 S $6 \ldots$

*Alternifolia (Blue Dogwood. H $6-8, \mathrm{~S} 6 \ldots 2$

Mascula (Cornelian Cherry). Very showy bright scarlet fruit. H 8-10, S $6-8 \ldots . . . .3$

*Sanguinea (European Red Osier). Deep red bark; black berries. H $6-8$, S $6 \ldots \ldots \ldots 20$

*Sericea. Red bark, bluish fruit. H $8-10$, 6-8

Stolonifera (Red Osier Cornel) Dwarfspreading shrub, white berries. H 4-5, S 5.20

*Stolonifera pendula. Pendulous variety of above; distinct and fine.

Spæthi aurea. Yellow variegated foliage. H $3-4$, S 4 .

Kousa (Japanese Dogwood). A white-flowering variety of great beauty and rarity; grows into a small tree................ 75 


\section{ORNAMENTAL FLOWERING SHRUBS, continued}

CORCHORUS Japonica (Kerria Japon-Each Per doz. 100 $i c a$ ). Single yellow; blooms freely in sum-

mer time. $\mathrm{H} 4-6, \mathrm{~S} 4 \ldots \ldots \ldots \ldots \ldots \ldots \ldots \$ 0 \quad 20 \quad \$ 200$

Japonica fl. pl. A superb summer-blooming shrub, with showy double yellow flowers.

H 4-6, S $3 \ldots \ldots \ldots \ldots \ldots \ldots \ldots \ldots \ldots \ldots$. . . . . . . beautiful, graceful foliage. A dainty, charming shrub that should be freely planted.

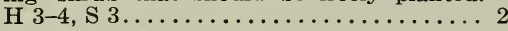

CORYLUS Americana (American Hazelnut).

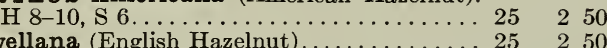

Avellana (English Hazelnut)........... $25 \quad 250$

Posford (Lareus (Purple Hazel). Rich purple 25 foliage......................... $35 \quad 350$

COTONEASTER Simonsi. Dwarf shrub with attractive red fruit; not very hardy........ $30 \quad 300$

CRAT EEGUS, or Hawthorn. Are very attractive spring-flowering shrubs. Very sweetscented and showy. They are large shrubs and eventually grow into small trees, but the growth is slow. They are covered with attractive red berries in the summer and fall. $\mathrm{H} 10-20$, S 10-20.

Coccinea (American Hawthorn)

Oxyacantha (English Hawthorn). .

Double-flowered Rose

Double-flowered Scarlet

Double-flowered White.

Pyracantha Lalandi (Evergreen Thorn) One of the most beautiful Thorns. Covered with splendid scarlet fruit in fall and winter. Not hardy north of Pittsburg, except near the coast.

CYDONIA Japonica (Japan Quince). Brilliant red; very subject to San José scale. H 4-5, S $5 \ldots \ldots \ldots \ldots \ldots \ldots \ldots \ldots \ldots \ldots$.

Columbia. A new variety with very large

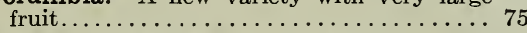

CERASUS Virginiana. A large shrub with brilliant showy fruit; very attractive. $\mathrm{H}$ $10-12, \mathrm{~S} 6-8 \ldots \ldots \ldots \ldots \ldots \ldots \ldots \ldots \ldots . \ldots \ldots$

$\begin{array}{lllll}30 & 3 & 00 & \$ 20 & 00 \\ 20 & 1 & 50 & 10 & 00 \\ 50 & 5 & 00 & & \\ 50 & 5 & 00 & & \\ 50 & 5 & 00 & & \end{array}$
5

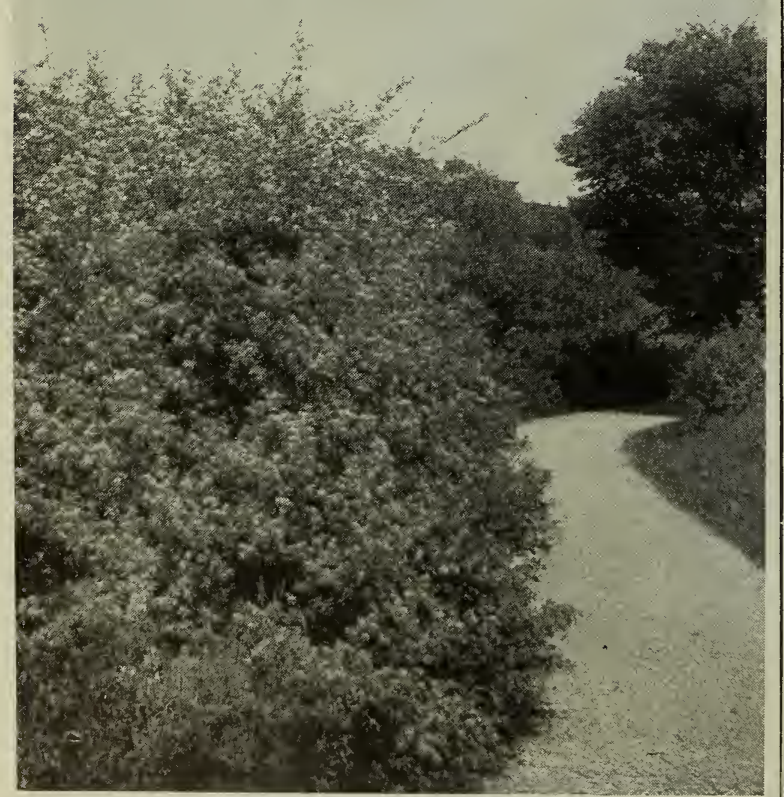

Lonicera bella (see page 56)
CYTISUS Laburnum (Laburnum or "Golden Each Per doz. 100 Chain") ....................... \$0 $50 \quad \$ 500$

DESMODIUM penduliflorum. An exceedingly graceful shrub-like plant, covered with purplish red flowers in summer-time when little else is in bloom; strikingly beautiful. H $3-4$, S $4 \ldots \ldots \ldots \ldots \ldots \ldots \ldots \ldots .20$

DEUTZIA candidissima. Double white flowers. H 6-8, S 6, May, June............ 20

Crenata fl. pl. Double pink flowers. H $6-8$,

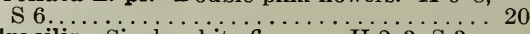
Gracilis. Single white flowers. H $2-3$, s 3 . May......................... 20

Parviflora. Pure white flowers. H 4-6, s 5. 30

Lemoinei. A dwarf and exceedingly freeflowering shrubs with pure white single flowers. H 3, S 3, May................. 20

Wellsi. Pure white double flowers. H $6-8, \mathrm{~S}$ 6 , May...................... 20

DIERVILLA sessilifolia (Native Weigela).... 25

ELAEAGNUS Longipes. A new and handsome shrub with edible fruit. True variety. H $6-8$, S $6 \ldots \ldots \ldots \ldots \ldots \ldots \ldots \ldots \ldots 25$

Umbellatus. H $10-12, \mathrm{~S} 8 \ldots \ldots \ldots \ldots \ldots 25$

Angustifolius. Silvery gray foliage, like the olive. $\mathrm{H} 10-12, \mathrm{~S} 8 \ldots \ldots \ldots \ldots \ldots \ldots .25$

EUON YMUS atropurpureus (American Burning Bush). H 8-12, S 6............ 35

Europæus (European Burning Bush) ....... 25

Alatus (Winged Burning Bush). H 6-8, S 6.25 EXOCHORDA

Grandiflora (Pearl Bush). A rare Chinese shrub with pure white flowers. H 8-10, S 6.25

FORSYTHIA Fortunei (Fortune's GoldenBell). Magnificent vigorous-growing shrub,covered with yellow bell-like flowers before the foliage appears in the spring. Splendid for planting on steep banks, and especially above a retaining wall, as some of the branches grow upright while the remainder will hang down over the wall for several feet. H 6-8, S 5 , April......................... 20

Suspensa (Drooping Golden Bell). Long,pendulous branches which hang down over a wall like a vine................... 20

Viridissima. This is the erect form of Forsythia. H $8-10, \mathrm{~S} 6 \ldots \ldots \ldots \ldots \ldots \ldots \ldots 20$

GENISTA elatior (Hardy Broom). A beautiful dwarf yellow-flowered shrub. H 3-4, S 4, June.......................... 25

Scoparia (Scotch Broom)........................ 20

HALESIA Tetraptera (Silver Bell). This is one of the most beautiful-flowering large shrubs in cultivation; pure white bell-shaped flowers. H $15-20$, S $8 \ldots \ldots \ldots \ldots \ldots \ldots 20$

HAMAMELIS Virginica (Witch Hazel). Blooms in late fall and early winter. $\mathrm{H} 6-8$,

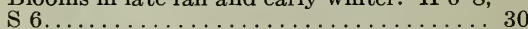

Japonica. A rare Japanese variety........ 75 HIPPOPHAE rhamnoides (Sea Buckthorn). H 8-10, S 8...................... 25

*HYDRANGEA arborescens. Native variety. 15

*Arborescens grandiflora. New variety with immense heads of white flowers. H 3, S 3. 30

Paniculata. Distinct from P. grandiflora. A very striking and elegant shrub. H 5-6, S 5. 20

Paniculata grandiflora. The well-known hardy Hydrangea. H 4-5, S $4 \ldots \ldots \ldots \ldots 20$

Quercifolia (Oak-leaved Hydrangea). Very handsome. H $3-4$, S $4 \ldots \ldots \ldots \ldots \ldots \ldots . \ldots 50$

* Radiata. Handsome native variety; fine for naturalizing. $\mathrm{H} 3-4, \mathrm{~S} 4 \ldots \ldots \ldots \ldots \ldots 20$

HYPERICUM densiflorum. Yellow flowers. H 2-3, S 3.

Moserianum. Extremely beautiful and desirable large golden yellow flowers........... 20

Prolificum. H $2-3$, S $2-3 \ldots \ldots \ldots \ldots \ldots \ldots 20$

II.EX verticillata (Deciduous Holly). Valuable for its brilliant scarlet berries in fall and winter. Will grow in swampy ground, and the berries are very fine for interior decorations. H 8-10, S $6 \ldots \ldots \ldots \ldots \ldots \ldots .35$
200

$200 \$ 1500$

300

$200 \quad 1400$

$\begin{array}{llll}2 & 00 & 1400\end{array}$

250

250

200

250

350

225

250

250

200 1500 


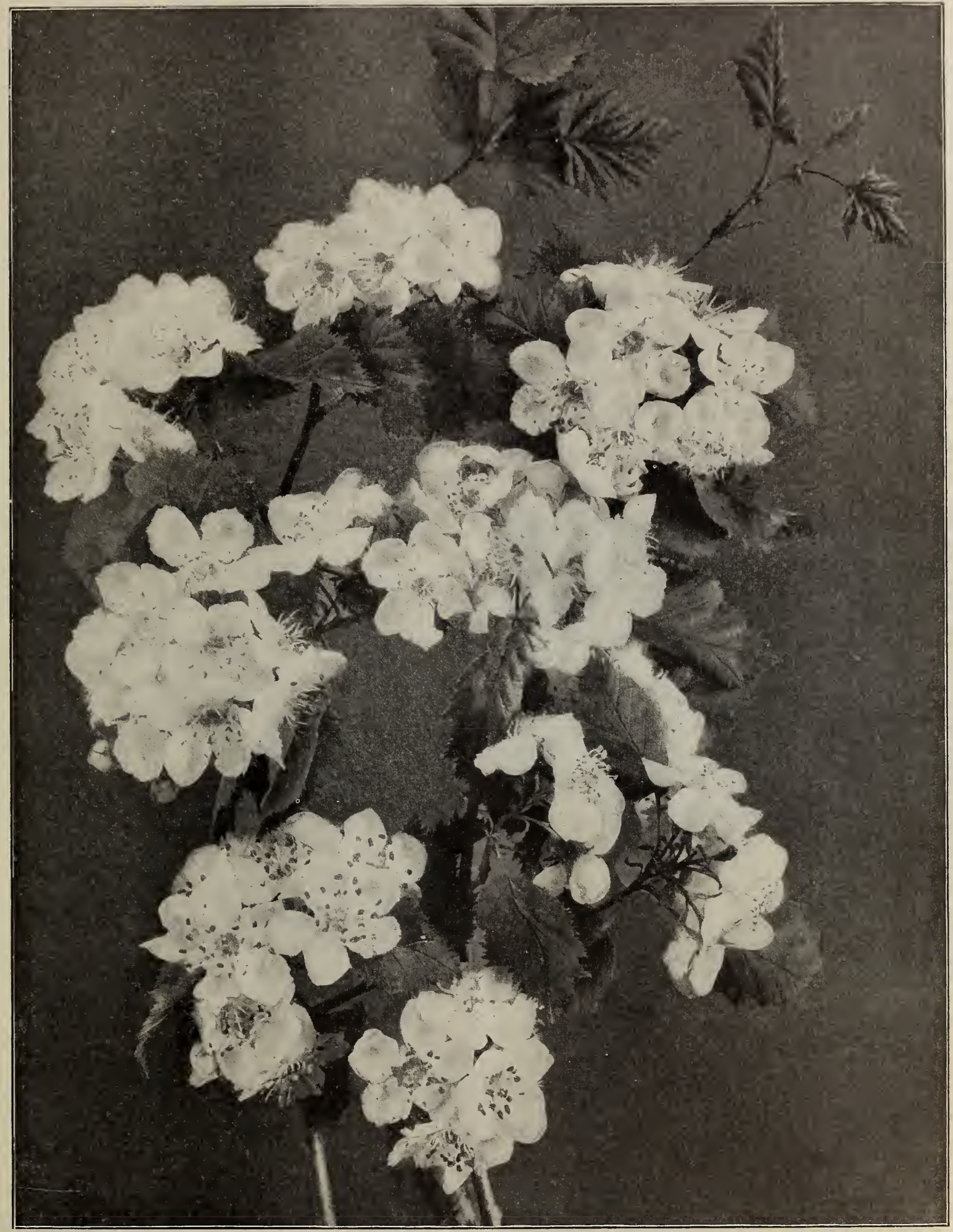

CRATAEGUS COCCINEA

One of our native shrubs which is beautiful in foliage, flower and fruit. It makes a dense shrub, and in time a small tree 


\section{ORNAMENTAL FLOWERING SHRUBS, continued}

ITEA Virginica. Sweet-scented white flowers in early summer. H $4-5$, S $4 \ldots \ldots \ldots \ldots \ldots \$ 0 \quad 20 \quad \$ 1 \quad 75$

IILAC, Common Purple. 2 to 3 feet....... 20 $200 \$ 1500$ 5 to 6 feet

Common White. 2 to 3 feet.

250

200

Persian. White and purple; small flowers... $25 \quad 2 \quad 50 \quad 1600$

\section{NEW VARIETIES OF LILACS}

Strong, 2-year budded plants (described below). For prices of named Lilacs, grown on their own roots, see page 18

Bertha Dammann. Immense trusses of pure white flowers; very profuse bloomer. $50 \mathrm{cts}$. each.

Emily Lemoine. Double; very large rosy lilac flowers; fine. 50 cts. each, $\$ 5$ per doz.

Lemoinei flore pleno. One of the oldest of the double Lilacs, and an excellent kind. Simply a double Vulgaris. Large and fine. $35 \mathrm{cts}$. each, \$3.50 per doz.

Hyacinthnoides. Hyacinth-like flowers. 35 cts. each, $\$ 3.50$ per doz.

Leon Simon. Double, compact panicles; flowers bluish crimson. 50 cts. each, $\$ 5$ per doz.

La Tour d'Auvergne. Double purplish violet. $35 \mathrm{cts}$. each, $\$ 3.50$ per doz.

Souvenir de la Spath. The most distinct and beautiful variety in the collection. Trusses immense; very compact; florets very large, deep purplish red. Growth vigorous. 35 cts. each, $\$ 3.50$ per doz.

Josikæa (Chionanthus-leaved Lilac). A very distinct and beautiful species from Hungary, with violet flowers blooming in early summer. H 8-10, S 8 . 30 cts. each, $\$ 3$ per doz.

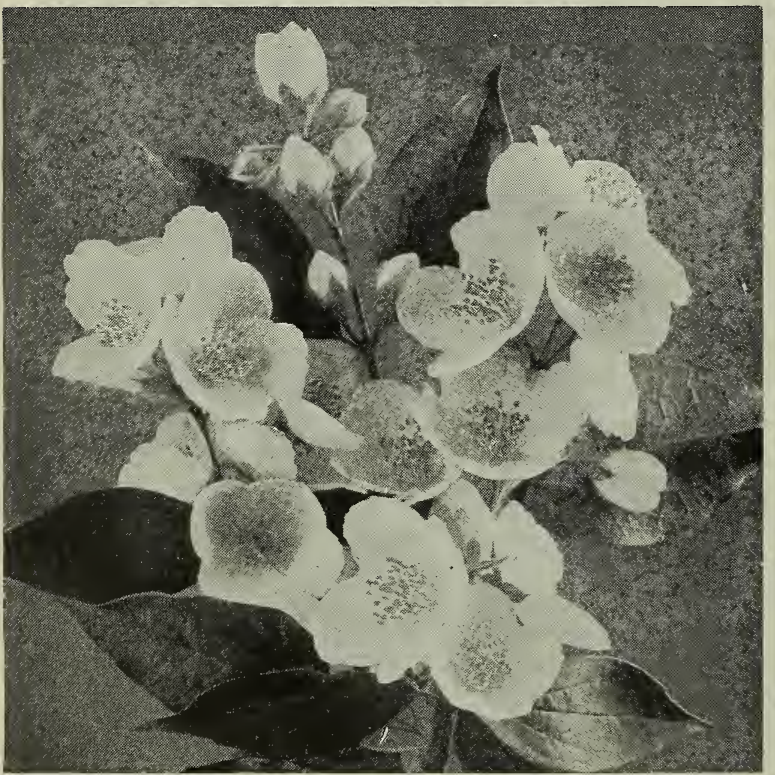

Philadelphus coronarius

LILAC, Japonica. A new and unique species Each Per doz. 100 from Japan, attaining the size of a small tree, with large panicles of white flowers; foliage very large, thick and deep green color; blooms a month later than other Lilacs. $\begin{array}{llll}\$ 0 & 50 \quad \$ 500\end{array}$

Villosa. Another new Japanese species, with foliage resembling the White Fringe (Chionanthus), and producing immense panicles of pinkish flowers late in the season; splendid. H 8-12, S 8 .

Emodi. A wild species with large shining leaves; whitish flowers in June.......... $25 \quad 250$

IONICERA (Upright Honeysuckle). These are very vigorous free-growing shrubs that are very showy and desirable both on account of
Lonicera, continued

their pink or white flowers which are freely produced in the spring and their bright red or orange fruit with which they are covered in the summer. $\mathrm{H} \mathrm{8-10,} \mathrm{S} \mathrm{6-8.}$

Morrowi. Flowers pure white; fruit red...\$0 25 \$2 $\$ 50$

Ruprechtiana.................. 20 200

Bella candida, rosea and albida. New and extremely beautiful in flower and fruit.... 25

Tatarica. Pink flowers.............. 20

Tatarica alba. White flowers................ 20

Xylosteum (Fly Honeysuckle)........... 20

Fragrantissima. A very early sweet-scented

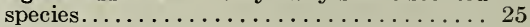

MYRICA cerifera (Wax Myrtle, Bayberry or Candleberry). H $4-6$, S $5 \ldots \ldots \ldots \ldots \ldots \ldots .35$

$250 \$ 2000$

200

200

200

AVIA macrostachya(Dwarf Horse-Chestnut). Beautiful spreading shrub with large heads of white flowers in June; fine for specimen on the lawn....................... 75

PHILADELPHUS (Syringa, or Mock Orange). Vigorous-growing with showy white and mostly sweet-scented flowers.

Aurea. Yellow leaved. H 4-5, S 4-5..... . 30

Coronarius. Very sweet-scented white flowers. H $8-10$, S $8 \ldots \ldots \ldots \ldots \ldots$

Falconeri. Starry white flowers, borne in great profusion. H $6-8$, S $6 \ldots \ldots \ldots \ldots \ldots \ldots 20$

Grandiflorus. Large flowers very showy. H

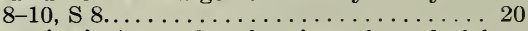

Lemoinei. A new dwarf variety of wonderful beauty. H $4-5, \mathrm{~S} 5 \ldots \ldots \ldots \ldots \ldots \ldots \ldots$.

Mont Blanc. One of the newer dwarf sorts; fusion. H $4-5$, S $5 \ldots \ldots \ldots \ldots \ldots \ldots \ldots \ldots$

Sutzmannii. Large showy white variety. $H$

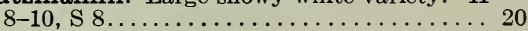

RIVET, California. Very popular for hedging but sometimes killed to the ground during very cold weather.

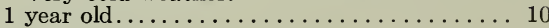

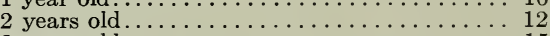

3 years old $\ldots \ldots \ldots \ldots \ldots \ldots \ldots \ldots \ldots \ldots \ldots \ldots \ldots \ldots \ldots 15$

*Regel's. An elegant new Privet; fine for the shrubbery or for hedges; perfectly hardy.

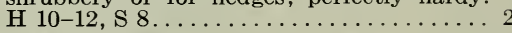

*Ibota. Very graceful and handsome...... 20

*Amoor River. (True.) Very hardy and desir-

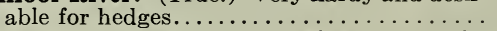

*Common. Desirable for hedging and hardier than California Privet.............. 10

Ligustrum Media. A Privet of beautiful habit; fruits immensely............. 25

POTENTILLA fruticosa ............ 25

PRUNUS Sinensis rubra. A dwarf Chinese Plum of great beauty. Double red flowers. 25

Maritima (Beach Plum). Dwarf bush Plum, which makes an extremely ornamental shrub on account of its flowers as well as its fruit, which is produced on bushes when only 2 feet high. The fruit is edible and makes an excellent preserve. H 5-8, S $6 \ldots \ldots \ldots \ldots .25$

Pissardi (Purple-leaved Plum). Desirable on account of its rich purple foliage. H 10-12,

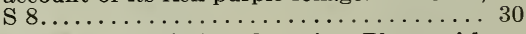

Triloba. A desirable flowering Plum with double pink flowers; very beautiful. . . . . 30

PHOTINIA Villosa. Very attractive red berries. H $10-12, \mathrm{~S} 8 \ldots \ldots \ldots \ldots \ldots \ldots \ldots \ldots$

PYRUS arbutifolia (Choke Berry). A native shrub of great beauty and easy culture. Covered with white flowers early in spring, followed by bright red berries which last all winter. H $4-5, \mathrm{~S} 5 \ldots \ldots \ldots \ldots \ldots \ldots \ldots$

REAMNUS cathartica (Buckthorn). Stronggrowing shrub with black berries. H 8-10, growing shrub with black berries. H 8-10, 20 
ORNAMENTAL FLOWERING SHRUBS, continued

RHUS copallina (Shining-leaved Sumac). Each Per doz. 100 H $4-6$, s $5 \ldots \ldots \ldots \ldots \ldots \ldots \ldots \ldots \ldots$. 30 . 35 \$3 50

Cotinus (Purple Fringe). H $8-10, \mathrm{~s} 8 \ldots \ldots 25 \quad 250$

Cotinus atropurpurea. Improved Purple Fringe........................ 50

Glabra laciniata (Cut-leaved Sumac). H 4-

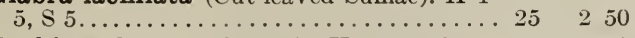

Typhina (Common Sumac). H 10-12, S 6. 20

Aromatica (Sweet-scented Sumac). H 4-6,

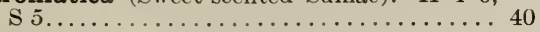

RIBES aureum (Missouri Currant). H 4-5, S 5. 20 Gordonianum. H $4-5, \mathrm{~S} 5 \ldots \ldots \ldots \ldots \ldots 20$

ROBINIA hispida (Rose-flowered Acacia). Extremely free-flowering and attractive.

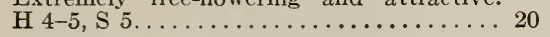

RUBUS odorata (Thimble Berry). Splendid foliage and purplish flowers all summer. H $20 \quad 125 \quad 800$

RHODORA-Canadensis. Small shrub with very pretty purplish flowers which appear in the spring before the leaves come out; very attractive. $\mathrm{H} 1-2, \mathrm{~S} 2 \ldots \ldots \ldots \ldots \ldots, 40 \quad 400$

SAMBUCUS Canadensis (Common Elderberry). Very striking when planted in rich soil. H $6-8 \ldots \ldots \ldots \ldots \ldots \ldots \ldots \ldots \ldots 20$

Canadensis aurea (Golden-leaved Elderberry). ..................... 20

Laciniata (Cut-leaved Elderberry)........ 25

*Pubens. This rare variety has bright red fruit in the spring, when the common Elderberry is in bloom; very showy......... 20

SPIR EA Arguta. Pure white flowers early in the spring. $\mathrm{H} 5-6, \mathrm{~S} 5 \ldots \ldots \ldots \ldots \ldots . .30$

Anthony Waterer. A beautiful dwarf flowering shrub of great popularity. "This is a seedling of that variety of Spircea Japonica which is known in gardens as $S$. Bumalda, and which is distinguished by its dwarf, compact habit, its persistent flowering, and bright red flowers. Spircea Anthony Waterer differs from its parent in the deeper, brighter and more intense color of the flowers. As it begins to flower freely when only a few inches high, and continues to produce its large, flat corymbs from July until frost appears, this shrub promises to be a capital addition to the rather short list of autumn-flowering hardy shrubs." H 2-3, S 3. Two-year-old plants. . 20

Ariæfolia. Tall, graceful variety with white flowers in summer................ 30

Billardi. Pink spikes of flowers in the summer. H $5-6$, S $5 \ldots . \ldots \ldots \ldots . \ldots 20$

Callosa. Pink flowers all summer. H 3-4, S 4. 25

Carpinifolia. Flowers in white panicles. H $6-8$, S $6 \ldots \ldots \ldots \ldots \ldots \ldots \ldots \ldots$

Douglasii. Deep pink spikes of flowers. Fine for massing. H 5-6, S 5, July, August.... 20

Lindleyana. Splendid foliage and flowers; very picturesque but not very hardy; needs a sheltered location and well-drained soil. H $5-6, \mathrm{~S} 6 \ldots \ldots \ldots \ldots \ldots \ldots \ldots \ldots \ldots, 35$

Opulifolia aurea (Ninebark). Vigorousgrowing variety with yellowish foliage; white flowers followed by showy seed-pods. H 8 -

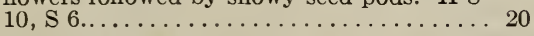

Paniculata rosea. A vigorous grower with pink flowers in July................. 20

Reevesii fl. pl. Double white flowers in May. H $5-6$, S $5 \ldots \ldots \ldots \ldots \ldots \ldots \ldots .25$

Frœbeli (Frœebel's Spirea). Free-blooming sort with pink flowers................ 20

Regeliana. Pink flowers in panicles. H 6 $-8, \mathrm{~S} 6 \ldots \ldots \ldots \ldots \ldots \ldots \ldots \ldots . \ldots \ldots 20$

Salicifolia (Willow-leaved Spirea)......... 20

Sorbifolia. A handsome variety with fernlike foliage and showy spikes of white flowers in July. H $3-4, \mathrm{~S} 4 \ldots \ldots \ldots \ldots \ldots \ldots 20$

$\begin{array}{llll}200 & 1300\end{array}$ 250

$\begin{array}{llll}2 & 00 & 14 & 00\end{array}$

$200 \quad 1400$
Spiræa Tomentosa. Pink flowers; hardy Each Per rloz. 100 and distinct. H 5-6, S 5........... \$0 $20 \quad \$ 175 \$ 1300$

Thunbergii (Snow Garland). The first shrub to flower in the spring; pure white flowers in profusion, Very lovely. H 4-5, S 4....20 200

Van Houttei. A very graceful variety. One of the best: by many people considered the most satisfactory shrub in cultivation; white flowers in the greatest profusion in May. $\mathrm{H} 6-8, \mathrm{~S} 6$. .

S YMPHORICARPOS. The Symphoricarpos are very desirable in the shade or under trees where nothing else will grow. They are covered with white or red berries in fall and winter.

*Racemosus (Snow-Berry). White-fruited. H $4-5$, S $5 . . \ldots \ldots \ldots \ldots \ldots \ldots \ldots \ldots \ldots$.

*Vulgaris (Indian Currant) Red-fruited.

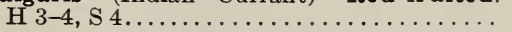

*Variegata. Beautiful variegated foliage. $\mathrm{H}$ $4-5, \mathrm{~S} 5 \ldots \ldots \ldots \ldots \ldots \ldots \ldots \ldots \ldots . . \ldots \ldots$

STAPHYLEA Colchica. Extremely sweetscented and free-flowering shrub; very desirable. H $7-8, \mathrm{~S} 6 \ldots \ldots \ldots \ldots \ldots \ldots$

$175 \quad 1300$ $20 \quad 1 \quad 75 \quad 1300$ $20 \quad 175 \quad 1300$ YRAX Japonica. This rare gem is one of
the most desirable shrubs known. When in bloom it is literally covered with creamwhite bells. $\mathrm{H} 12-15, \mathrm{~S} 10 \ldots \ldots \ldots \ldots .35$ EPHANANDRA flexuosa. A very graceful shrub, with deeply cut fern-like foliage. H $3-5, \mathrm{~S} 4 \ldots \ldots \ldots \ldots \ldots \ldots \ldots \ldots \ldots . \ldots \ldots$ UARTIA pentagyna. A very rare shrub
with exquisitely beautiful, large, single white flowers in July. $\mathrm{H} 6-8 \ldots \ldots \ldots \ldots .1$

TAMARIX. Tall, slender shrubs with feathery foliage and large panicles of lovely pink flowers in late spring or early summer.

Africana. H 8-10, S $6 \ldots \ldots \ldots \ldots \ldots \ldots 25 \quad 250$

Aestivalis hispida. H $8-10, \mathrm{~S} 6 \ldots \ldots \ldots 25 \quad 250$

Plumosus (Japanese Tamarix). H 10-12, S 6. $25 \quad 250$

VIBURNUM Lantana. Showy red fruit. H 8

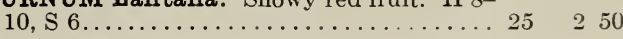

Opulus sterilis (Snowball). H 8-10, S 8... $20 \quad 200$

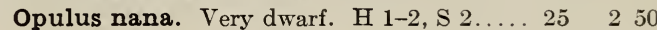

Oxycoccus (Cranberry Tree). Very showy red fruit. H $8-10, \mathrm{~S} 8 \ldots \ldots \ldots \ldots \ldots \ldots 30$

Plicatum (Japan Snowball). One of the choicest shrubs. H $8-10, \mathrm{~S} 10 \ldots \ldots \ldots \ldots 35$

Dilatatum. Scarce and choice..........100

Tomentosum. Rare and choice. H 8-10,

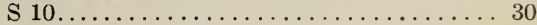

Dentatum. A most beautiful and satisfactory shrub. H $6-8, \mathrm{~S} 6 \ldots \ldots \ldots \ldots \ldots \ldots 25$

Macrocephalum. A rare variety of great beauty; immense heads of white flowers.

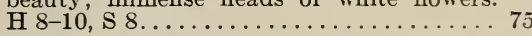

VITEX Agnus-castus (Chaste Shrub). Blue.. $20 \quad 150$

White........................... $20 \quad 150$

WEIGELA candida. White Decidedly the most desirable of its color. H 6-8, S \& ... 20 20 00

Rosea. Pink flowers. H 6-8, S 8........ 20 200

Rosea nana variegata (Variegated-leaved). $\mathrm{H} 4-5, \mathrm{~S} 5 \ldots \ldots \ldots \ldots \ldots \ldots \ldots \ldots \ldots \ldots 20 \quad 200$

Floribunda. Crimson. H 6-8, S $8 \ldots \ldots \ldots 25 \quad 250$

Eva Rathke. Very valuable everblooming variety; large crimson flowers. H $5-6, \mathrm{~S} 6.25$ Conquete. (Novelty.) Enormous flowers, deep rose...................... 35

Amabilis. Light pink. H $6-8$, S $8 \ldots \ldots \ldots 20 \quad 200$

Lavallei. Dark, purplish red flowers....... 20 200

XANTHOCERAS sorbifolia. Rare and beautiful............................ 75

XANTHORRHIZA apiifolia,..., . . . . 25 


\section{Evergreen Shrubs}

All Evergreen Shrubs should be planted early in September and in the spring

ANDROMEDA floribunda. Very neat Each Per doz. 100 dwarf evergreen shrub, with lily-of-thevalley-like flowers, desirable and rare....\$1 $50 \$ 16 \quad 00$

Japonica. Evergreen variety from Japan. very attractive................. $150 \quad 1600$

BERBERIS Neuberti. Holly-shaped leaves; very handsome.....................

DAPHNE Cneorum. Exquisite creeping everand charming; pot-grown plants.........

ILEX opaca (American Holly).

Crenata. A dwarf Holly of beautiful habit and foliage; perfectly hardy, and covered with black berries in the winter.

$30 \quad 300$

300

$50 \quad 500$

*KALMIA latifolia. Known as the Smallleaved Mountain Laurel. One of the most beautiful flowering shrubs in cultivation. Nice, small nursery-grown plants........
*LEUCOTHOE Catesbæi. Graceful ever- Each Per do: 108 green shrub, with white, bell-shaped flowers....................... \$0 25 \$2 50

*MAHONIA aquifolium............... $\quad 20 \quad 2 \quad 00 \$ 1200$

*RHODODENDRON maximum. Our wellknown Mountain Rhododendron, blooming in July. Nice nursery-grown plants. . Larger plants, $\$ 1, \$ 1.50, \$ 2, \$ 3, \$ 4$ and $\$ 5$ each. Plants $\$ 3$ and $\$ 5$ each are splendid specimens.

*Catawbiense. The wild Rhododendron of the southern mountains; very desirable. Fine nursery-grown plants............. $100 \quad 1000$

*Punctatum. A dwarf native Rhododendron with pale pink flowers; very early; nice; 18 to 24 inches............... $100 \quad 1000$

\section{Ornamental Deciduous Trees}

With the exception of Birches, Dogwoods, Magnolias, Pin Oaks and Willows, we do not grow trees. The following list of trees is selected from the best nurseries in the United States. Orders will be shipped from the nearest nursery that can supply the stock ordered, so as to save freight charges and secure quickest possible delivery; where stock is ordered in considerable variety, it is sometimes shipped from two or more nurseries to secure trees of the best quality. We always endeavor to secure the best stock in the market for our customers. The prices quoted are for trees of the most suitable size for transplanting; extra-large trees of many varieties can be supplied, but are not recommended. If quick results are desired they can be had by taking small- and medium-sized, but perfectly vigorous and healthy trees, and give them liberal planting; for instance, dig a hole 3 feet deep and 5 feet in diameter for each tree, ard fill with all good surface soil, mixed with one-fourth of its bulk of rotted stable manure.

It costs considerable to plant trees in this manner, but the results justify the expense, and people of ten pay from $\$ 10$ to $\$ 50$ each for larger trees, which always fail, generally dying outright within three years, and never making vigorous, healthy trees. Some kinds of trees may be safely planted much larger than others. Magnolias, Beeches, Tulip Trees and white-leaved Lindens are difficult to transplant, and small-sized trees of these should always be selected. Some varieties should always be planted in the fall, others in the spring, and we shall be glad to advise our customers on these and other points in regard to planting.

Lowest net prices will be quoted for trees by the 100 and 1,000, on application. Specially desirable trees are marked with asterisk (*).

AILANTHUS glandulosa. Female trees, which are Each Per doz. almost free from disagreeable odor..........\$0 $75 \quad \$ 800$

ALDER, Cut-leaved.

125

*ANDROMEDA arborea (Sorrel Tree). A scarce and

ASH, American White.

BALM OF GILEAD. See Poplars.

BEECH, the noblest of trees, but are of slow growth

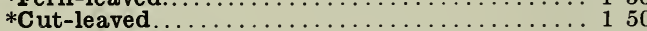

*BIRCH, European White................ 50

Double-flowered white
European... extremely beautiful flowering small tree.........

English. and difficult to transplant. Small trees should always be selected and well pruned when planted.

\section{*English}

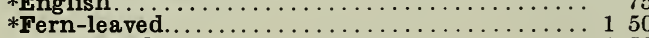

*Purple-leaved ........................ 150

*Weeping .......................... 150

*Cut-leaved Weeping ...................... 100

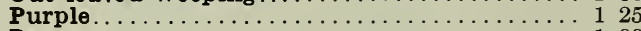

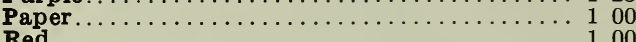

Sweet

Plant Birches in the spring.

BUTTONWOOD. See Sycamore.

CATALPA Bungei (Indian Bean or Cigar Tree).

Standard......... $\$ 3, \$ 5, \$ 7.50$ and $\$ 10$ each.

Bungei. Grafted at the ground.

Speciosa. Our native variety...

CERCIS Canadensis (American Judas Tree).......

Japonica (Japanese Judas Tree).

CHERR Y, European Bird

American Wild

Double-flowered Pink.

Rose-flowered (Weeping Japanese). Unique and beautiful flowering tree.

800

$50 \quad 500$

$75 \quad 800$

$\begin{array}{lll}70 & 7 & 00\end{array}$

700

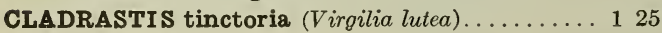

1500

1600

500

1300

1000

1000

800
CRAB APPLE. The ornamental Crab Apples are un- Each Per doz. doubtedly the most beautiful small-flowering trees in cultivation; even more beautiful than the popular Magnolias. They are of the easiest culture, hardy, and bloom when quite small.

*Parkman's (Pyrus Parkmani)...............\$1 00

*Bechtel's New Double-flowered............ 75

*Common Wild (Pyrus coronaria) .............. 60

Double White (Pyrus spectabilis) ............. 75

Floribunda. Single-flowered, pink; one of the most

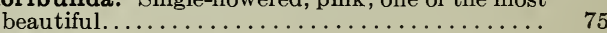

CYPRESS Deciduous..................... 75

*DOGWOOD, White-flowering

$*$ Red-flowering.

Weeping . . . . . . . .

*ELM, American

English.

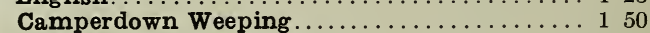

*HONEY LOCUST, American ............. 60

*HORSE-CHESTNUT-

White-flowering ..................... 150

Double White........................... 150

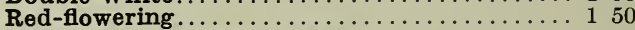

KENTUCKY COFFEE TREE (Gymnocladus Cana-

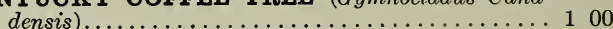

KGLREUTERIA paniculata ............ 75

LARCH, European ................. 30

LIN DEN, American................... 125

*White or Silver-leaved. A superb tree......... 200

European........................... 100

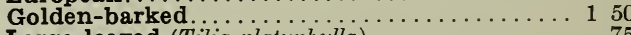

$\begin{array}{lll}\text { Large-leaved (Tilia platyphylla)......................... } & 75 \\ \text { White-leaved Weeping. A splendid pendulous tree } 2 & 50\end{array}$

LIQUIDAMBAR styraciflua (Sweet Gum)....... 100

MAGNOLIA acuminata (Cucumber Tree)........ 75

Glauca (Sweet Bay).................... 75

Macrophylla (Giant-flowered Magnolia). Flowers 150

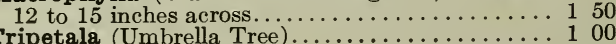

$\$ 800$

600

750

850

800

400

800

800

1000

1300

600

1600 1700

800

350

1350

2200

800 
ORNAMENTAL DECIDUOUS TREES, continued Chinese and Japanese Magnolias

MAGNOLIA conspicua. A superb large-flowered Each Per doz. white Magnolia.......................\$5 00

Purpurea (Obovata). Purple............. $50 \$ 500$

*Soulangeana. White, pink center; a splendid sort that is literally covered with large flowers early in the spring. Specimens prepared for transplanting............................. 300

*Stellata (Halleana). A dwarf, white variety of exquisite beauty................... 150

Hypoleuca. A choice Japanese variety........ 250

Parviflora (Watsoni). A very scarce and extremely lovely Japanese variety................. 250

Lennei. A beautiful sort, with large purple flowers. 500

Kobus. A Japanese white variety............. 75

Gracilis. Purple flowers................... 50

Magnolias should be planted in the spring.

MAPLE, Ash-leaved (Box-Elder)........... 75

European Cork .......................... 75

Norway........... 150

Purple Norway................... 150

Schwedler's Purple.................. 250

Silver-leaved (Water, or Soft) ............ 75

Striped Bark (Acer Pennsylvanicum)........... 100

Sugar, or Rock. . . . . . . . . . $15 \ldots \ldots \ldots \ldots \ldots$

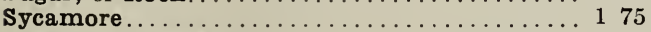

Wier's Cut-leaved..................... 75

Red or Scarlet.............................. 100

Mountain (Acer spicatum). Small . . . . . . . . . 35

Tartarian....................... 100

MOUNTAIN ASH, European ............. 50

MULBERRY, New American ............... 50

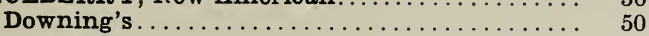

Russian ...................... 40

White........................... 40

Teas' Weeping.......................... 100

NUTS, Almonds. Hard or soft shell. . . . . . . . . 30

Chestnut, American ................... 50

Alpha ................................. 150

Perry's Giant ......................... 150

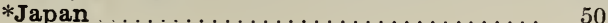

Spanish ...................... 40

*Paragon ...................... 100

*Numbo $\ldots$

*Hickory (Shellbark) ................... 50

Walnut, Black...................... 40

English........................ 75

Japanese....................... 60

OAK. The planting of Oaks for ornament has been done but little on account of their supposed slow growth. They grow quite as rapidly as other hardwood trees, and the Pin Oak is of a very rapid growth, and one of the finest trees in cultivation.

*White 6 to 8 feet..................... I 50

Turkey....................... 150

*Scarlet. A grand tree, with splendid coloring in fall. 150

Laurel-leaved.

OAK, Pin (Quercus palustris). One of the very finest trees for avenue or lawn planting, and of very rapid growth. The great demand for this tree has made it very scarce. 5 to 6 feet................

6 to 7 feet................................ 90

7 to 8 feet.................................. 100

9 to 10 feet...................................

10 to 12 feet...............................

10 to 12 feet; specimens..................... 500

Golden........................... 200

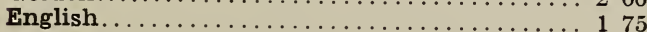

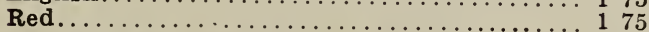

*PAULOWNIA inıperialis (Empress Tree)........ 50

PEACF, Double-flowering. Pink, white and crimson...........................................

PERSIMMON, American

35

75

PHOTINIA, villosa. A very ornamental tree covered with red berries in fall and winter.

700

500

800

700

1600

1400

2400

800

1600

1400

800

1000

350

1000

500

500

500

400

400

300

500

500

400

1100

1100

500

400

$\begin{array}{ll}7 & 50 \\ 6 & 00\end{array}$
PLANE. See Sycamore.

PLUM, Purple-leaved (Prunus Pissardi)

POPLAR, Carolina.

Lombardy.

Pyramidal (Bolleana)

Golden.

Balsam (Balm of Gilead)

SALISBURIA adiantifolia (Gingko, or Maidenhair

Tree) $\ldots \ldots \ldots \ldots \ldots \ldots \ldots \ldots \ldots \ldots \ldots \ldots \ldots \ldots \ldots$
SASSAFRAS. A small native tree; seldom used, but

(Gingko, or Maidenhair 100

Each Per doz.

$\$ 0 \quad 25 \quad \$ 2 \quad 50$

$35 \quad 350$ extremely desirable for its foliage....

1100

SOPHORA Japonica

550

SYCAMORE, Oriental. The Oriental Sycamore is

extensively used in Europe for street planting.... 150

1700

THORNS. See Hawthorn, under head of Hardy Shrubs.

TULIP TREE (Liriodendron Tulipifera) . . . . . . . 75

800

WILLOW, Weeping

Kilmarnock

Regal. White foliage

Laurel-leaved. Very handsome.

Salamonii. New Weeping, of remarkably rapid growth.

Golden-barked

Flame-colored.

50

75

40

30

400

300

75

800

$25 \quad 250$

$20 \quad 200$

YELLOW WOOD. See Cladrastis. 


\section{Evergreens}

The prices quoted are for trees frequently transplanted and of fine shape, suitable for ornamental planting. When it is desired to make extensive plantations, extremely low prices can be made by the 100 and 1,000. Evergreens should be planted in the spring. Many seasons they can be planted safely in September, but the risk of shipping at this time is great, on account of hot weather.

Rare evergreens, not obtainable in this country, will be imported to order.

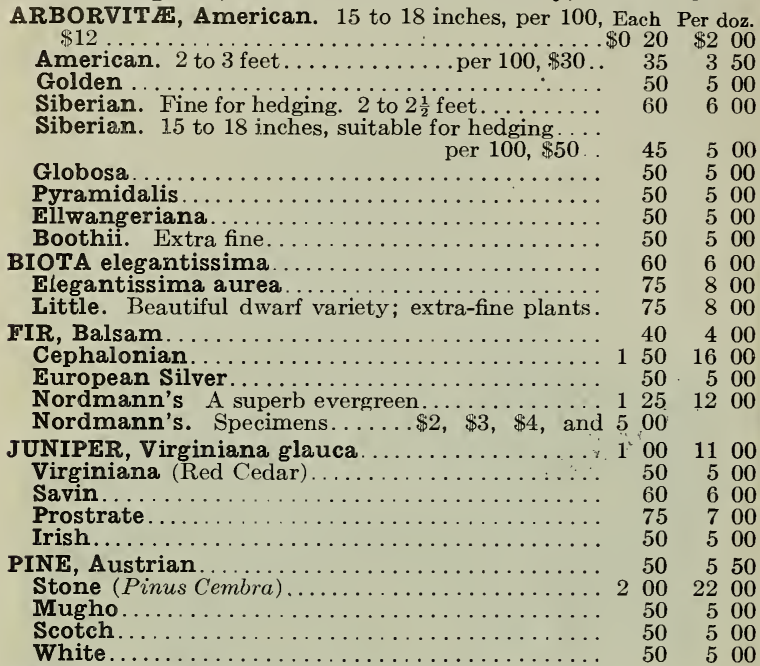

RETINOSPORA. The Retinosporas are all smallgrowing evergreens of exquisite foliage and fine coloring. They can be used on small grounds, as they take up but little room.

Aurea gracilis..................... 100

Filifera................................ 50

Retinospora, continued

Filifera aurea.

Leptoclada....

Obtusa compacta aurea. 1 to $1 \frac{1}{2}$ feet

Plumosa.

Plumosa aurea

Pisifera.

Pisifera aurea.

SPRUCE, Alcock's

Douglas'. Mag

very hardy

Hemlock. This native evergreen is one of the finest and most graceful trees in cultivation. It makes the most beautiful of all evergreen hedges. 12 to 18 inches. ................ per $100, \$ 35$.

Hemlock. 24 to 30 inches...... per 100, $\$ 65$.

Colorado Blue. One of the most beautiful ever-

greens, and one of the hardiest. 18 to 24 inches. 250

Colorado Blue. Selected blue specimens. 2 to $3 \mathrm{ft}$. 350

Colorado Blue. Selected blue specimens. 3 to $4 \mathrm{ft}$. 500

Colorado Blue. Green form often sent out as the

true blue......... $\begin{array}{llll} & 00 & 9 & 00\end{array}$

Concolor. Very scarce and beautiful. 2 to 3 feet. 2002200

Norway. (Very low prices by the 100 or 1,000 )... $35 \quad 350$

Weeping Norway. Very curious and picturesque

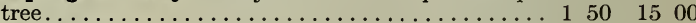

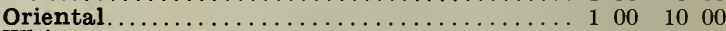

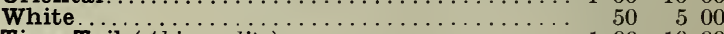

Tiger Tail (Abies polita) .................... $100 \quad 1000$

YEW, Irish Golden . . . . . . . . . . . . . 250

English . . .

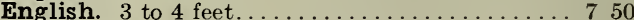

Golden. $1 \frac{1}{2}$ to 2 feet........................ 300

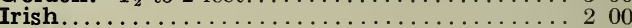

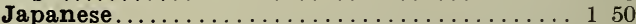

\section{Ornamental Hedges}

Hedges can be used to advantage on all suburban and country places, large or small. Where protection against cattle is not needed, a well-kept hedge is far more beautiful than the most costly wall or fence. At Newport, the most beautiful summer resort in America, hedges are very popular and are used more than either walls or fences. We have made arrangements for supplying all the best varieties of hedge plants at extremely low prices.

\section{Trimmed Hedges}

CRAT \&GUS Oxyacantha (English Hawthorn). This is the Thorn that is used all over England for field and farm hedges. Per 100

HEMLOCK SPRUCE. This undoubtedly makes the most peautiful evergreen hedge that can be grown in this climate. It is perfectly hardy, a fine rich green in color, which color it retains all through the winter; and no matter how hard it is trimmed, the peculiar feathery appearance of its young growth always gives it a graceful appearance. Plant 18 to 24 inches apart. 8 to 15 inches.................

MAHONIA aquifolium. This, which is one of the most beautiful evergreen shrubs, makes a splendid hedge. It is covered with showy yellow flowers in the spring, but its greatest beauty is its foliage, which is fine at all seasons of the year, but especially so in the fall and winter, when it turns to the finest bronze and crimson. Plant 18 inches apart ........

PRIVET Regel's. The very best privet for hedging or any other purpose; beautiful habit and foliage and perfectly hardy. 12 to 18 inches. $2 \frac{1}{2}$ to 3 feet.

PRIVET, Amoor River (True). Upright-growing like California but perfectly hardy. This variety must not be confused with so-called Amoor River Privet, sold in the South, which is really Ligustrum Chinense, and not hardy in the North. .

PRIVET, California. Immensely popular for hedging but very inferior to Regel's Privet and not reliably hardy here and further north.

1 year old.

2 years old

3 years old

Common. Makes a good hedge and will stand in extreme northern states, where California Privet is not hardy.

\section{Untrimmed Hedges}

Untrimmed hedges are allowed to grow naturally without pruning, and, as a rule, are not suitable for planting on the boundaries of grounds, but can be used for enclosing flower or vegetable gardens, on the edges of terraces and along roads and walks. Sometimes they can be used to conceal unsightly but necessary fences.

ALTHAA (Rose of Sharon). These make a desirable flowering hedge; bloom in August. They should be cut back to keep them compact. Extra-strong plants, seedlings... \$8 00

Best Named Varieties. Strong plants............... 1400 BERBERIS Thunbergii (Japanese Barberry). One of the most beautiful shrubs in cultivation, either for hedging or general purposes. It is of a neat, compact growth and never need be touched with the shears. The foliage is beautiful at all times, and in the fall turns to a most brilliant crimson color, but its most attractive feature is its fruit. The plant is literally covered with bright scarlet berries all the fall and winter. Plant 15 to 18 inches apart. Large plants...

CORCHORUS Japonicus variegatus. This makes one of the daintiest little hedges imaginable. The growth is slender and graceful, the foliage is of fine form and variegated, and after the leaves drop in the fall the twigs are a bright green color, which makes it attractive all winter............

LILACS. The common Purple and White Lilacs make a desirable flowering hedge, but, of course, a very tall one. I can supply both colors, nice plants, 1 to 2 feet high.....

ROSE, Crimson Rambler. This remarkable fine climbing Rose makes a superb hedge if planted in a row, and cut back early every spring to about three feet high....

Sweetbrier. The popular Sweetbrier makes an attractive hedge and is desirable for planting along a fence........

Mad. Plantier. This well-known hardy white Rose makes a fine hedge, and when in bloom in June nothing can be more attractive..............................20 00 


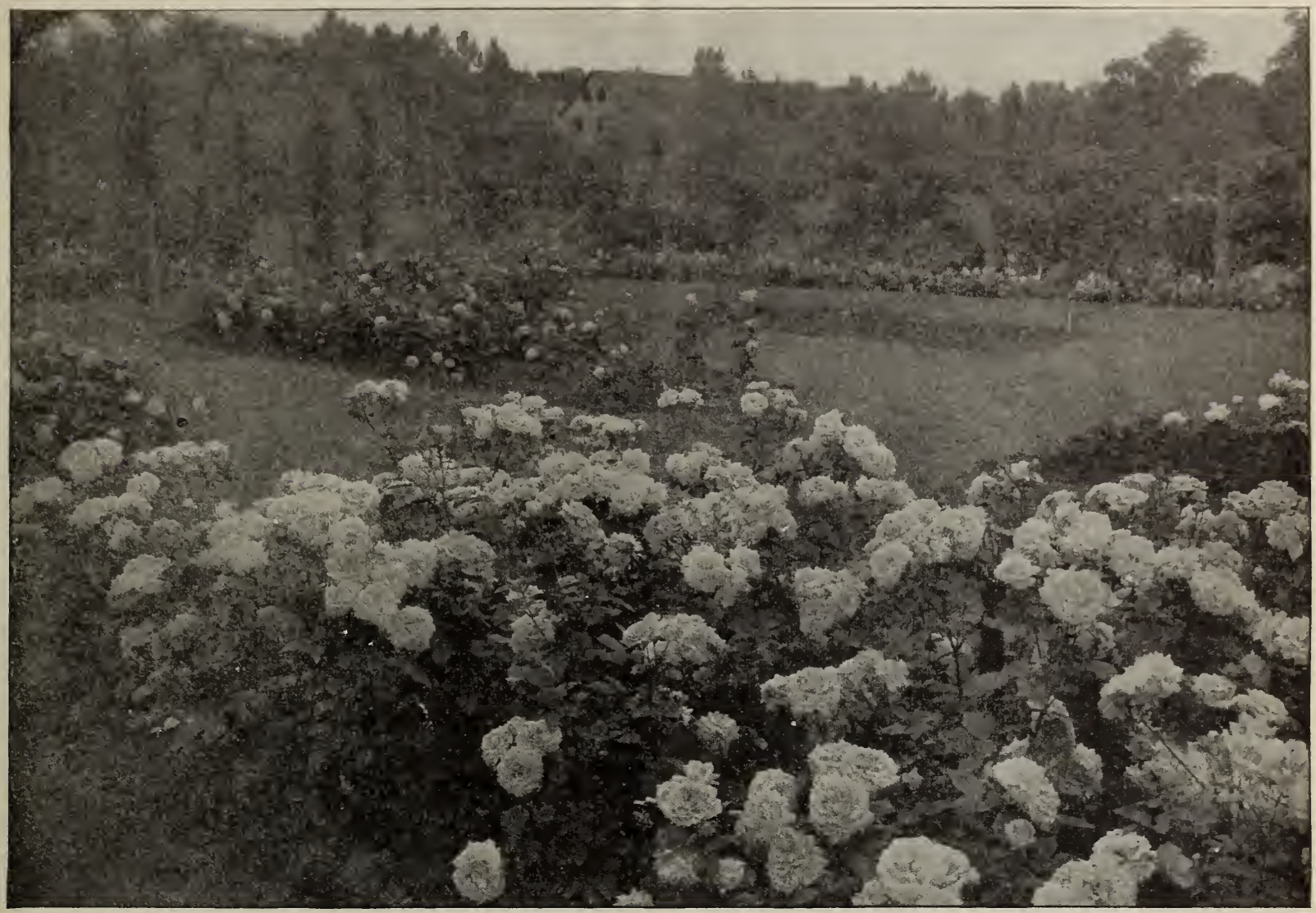

\section{Roses for Spring Planting}

Dormant Hardy Roses can be supplied from October 20 to April 1. Tea Roses all the year.

The fall is a much better time for planting Hardy Roses than the spring, and better plants and a better assortment of varieties can be obtained in the fall. Tea Roses all the year. In planting dormant Roses in the spring it is important that they should be planted as early as possible and two-thirds of their tops cut off before planting. All our Roses are American-grown and of the best quality obtainable. Hybrid Perpetuals and Moss Roses are principally low-budded plants; all other kinds are grown on their own roots.

Our collection of Wild Roses and old garden varieties is the most complete in America and contains many varieties not obtainable elsewhere.

We must emphasize the importance of cutting back dormant Roses when planting. More Roses die in transplanting for lack of this precaution than for any other reason. In planting dormant Roses in our nursery we cut them back to within 3 inches of the ground and, although this is never done until late in May, we rarely lose a plant.

If Roses are received in a dried condition, it is a good plan to soak them in water for 24 hours before planting.

For late delivery we can supply many varieties of Roses grown in pots; but growing them in pots adds greatly to their cost, also to the cost of transportation. Prices of pot-grown Roses will be furnished on application.

\section{Hybrid Perpetuals}

Anne de Diesbach, Baron de Bonstetten, Coquette des Alpes, Earl of Dufferin, General Jacqueminot, Jules Margottin, Madame Plantier, Mme. Gabriel Luizet, Magna Charta, Victor Verdier, Paul Neyron, Prince Camille de Rohan, Clio, La France, Margaret Dickson, Mrs. R. G. S. Crawford, Alfred Colomb, Baroness Rothschild, Marchioness of Lorne, Mrs. John Laing (one of the best, very free-flowering), Ulrich Brunner, Coquette des Blanches, Marshall P. Wilder, Vick's Caprice, Caroline de Sansel, John Hopper, American Beauty, Captain Hay, John Keynes, Marchioness of Dufferin, Oakmont, Barbarossa, Duke of Edinburgh, Eugene Furst, Francois Levet, Gloire Lyonnaise, Hugh Dickson, Jubilee, Nova Zembla.

Two-year-old plants, 35 cts. each, $\$ 3.50$ per doz., $\$ 25$ per 100

\section{Miscellaneous Roses}

Everblooming.-A finestock in 4-inch pots, Annie Muller, Crimson Baby Rambler, White Baby Rambler, Bon Silene, Bridesmaid, Clothilde Soupert, Gruss an Teplitz, Golden Gate, Helen Gould, Kaiserin Augusta Victoria, Killarney, Marie Guillot. Meteor,
Everblooming Roses, continued

Maman Cochet (pink), Maman Cochet (white), Mad.

de Watteville, Perle des Jardins, Rhea Reid, Souv

du President Carnot, The Bride, Wellesley..

Per doz. 100

Moss.-Salet, Glory of Mosses, Perpetual, White-crest-

.

Rugosa.- - Rugosa mubra and alba. Mme Geo. Bruant. $300 \quad 2000$

Briar.-Rosa rubiginosa (Genuine Scotch Sweetbriar). $200 \quad 1200$

Climbing Roses.-Queen of Prairie, Baltimore Belle,

Seven Sisters, Tennessee Belle, Russell's Cottage... $250 \quad 1500$

Marechal Niel..................... 30 cts. each... 300

Marechal Niel. Extra-strong plants........... 50

Tree Roses. (Not recommended.)........... 2000

New Rugosa Rose (Blanche Double de Coubert). This is a new semi-double Rugosa Rose, with all the good qualities of the species and the most exquisite semidouble white flowers we have ever seen. .35 cts. each. 350

Conrad F. Meyer (Rugosa hybrid). Silvery rose; large and full: one of the best of the new Rugosas. 35 cts. ea. 350 


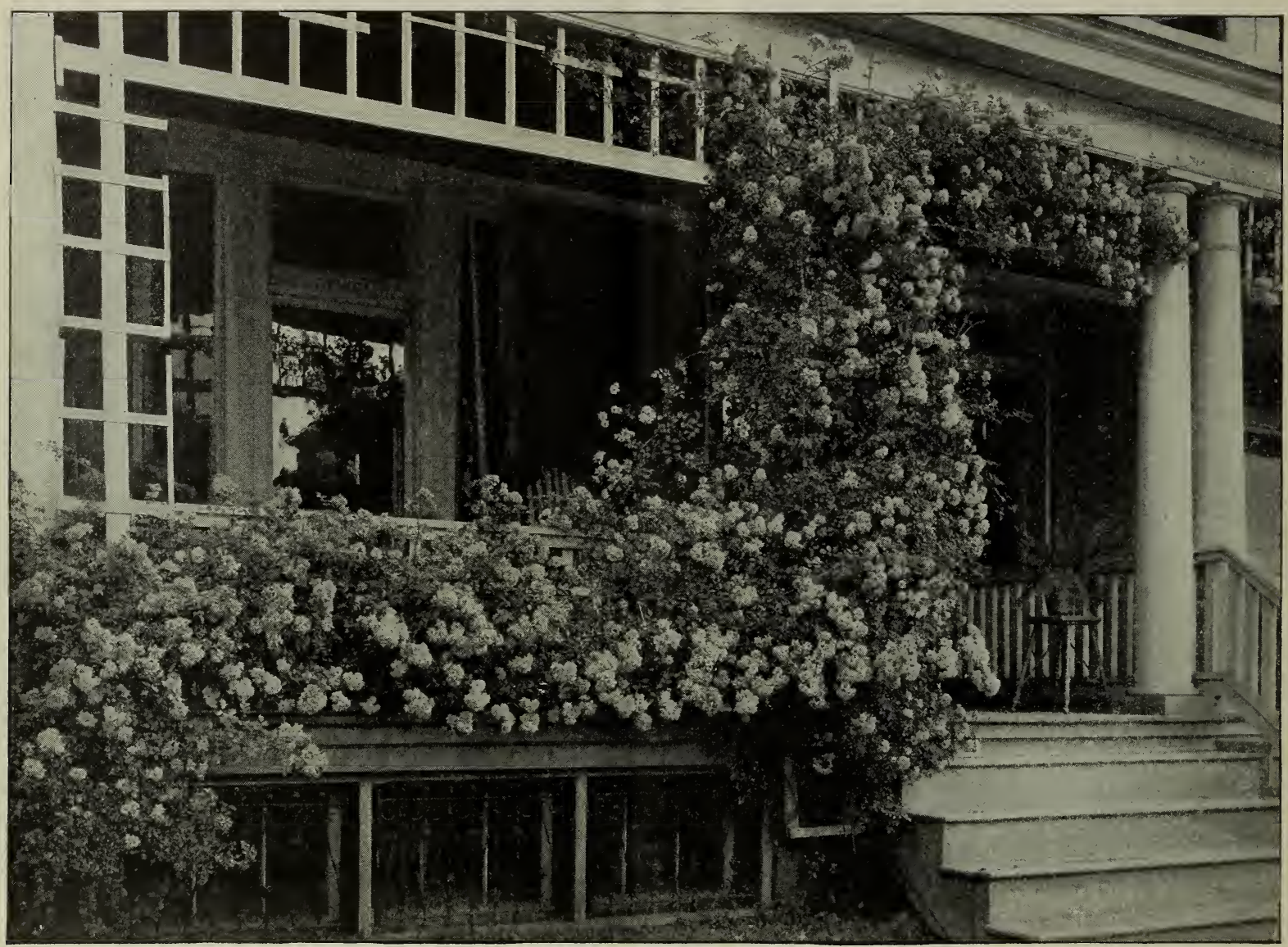

Climbing Rose, Lady Gay

\section{Climbing Rose, William G. Egan}

This is a distinct and very desirable candidate for a position on our list of choicest climbing Roses. Being convinced of its many excellent properties, we have grown a large stock of healthy young plants, and take special pride in their dissemination. It was raised by Mr. Jackson Dawson, of the Arnold Arboretum, Boston, Mass., and is the product of Wichuraiana crossed by General Jacqueminot, without any trace of either in the bloom. The habit of the plant is sub-climbing, but vigorous and healthy, with bright glossy, foliage. The flower is large and very full, resembling in shape, as well as color, the Souvenir de la Malmaison. Although only an annual bloomer, it remains in flower several weeks and the large trusses of superb bloom are unusually attractive. Mr. Dawson considered this the best of all his numerous hybrids. It is unquestionably reliable and hardy, at the North. Field-grown plants, strong and healthy, 2 years, $35 \mathrm{c}$. each, $\$ 3.50$ per $\mathrm{doz}$.

\section{New Hardy Rose, Frau Karl Druschki}

This is the most beautiful of all hardy white Roses, and the freest flowering, continuing in bloom from June until November. Strong budded plants, $40 \mathrm{cts}$. each, $\$ 4$ per doz.

\section{New Rambler Rose, Tausendschon}

This is an entirely distinct break, not only in Ramblers but in Climbing Roses generally. The individual flowers are very large for this type of Rose, being fully 3 inches across and of a most elegant and graceful form, not stiff or unnatural, but as beautiful as a semi-double Azalea. In color it is a most delightful shade of soft pink when first opening, changing to carmine on the reverse of petals when fully expanded. These are produced in trusses of from 10 to 15 flowers. 2 year-old plants, 50 cts. each, $\$ 5$ per doz.

\section{Rose, Lady Gay}

A new Rambler variety of remarkably vigorous growth, with flowers of a delicate cerise Pink, passing to soft-tinted White. The effect of a plant in full bloom with the combination of the soft white flowers, cherry-pink buds, and the deep green of the foliage is indeed charming. Strong two-year-old plants, 40 cts. each, $\$ 4$ per doz. 


\section{Rambler Roses}

CFIMSON. It is strikingly beautiful, absolutely hardy, and no Rosc can be used for more purposes. As a climber it is unsurpassed, perhaps unequaled as a pot-plant for forcing, the florists are finding it extremely popular. By keeping it cut down it makes a splendid bedding Rose, and a hedge of it is a most beautiful object. 30 ets. each, $\$ 3$ per doz., $\$ 20$ per 100 ; a few extra-strong plants 50 ets. each.

YELLOW. 30 cts. each, $\$ 3$ per doz.

WHITE. 30 cts. each, $\$ 3$ per doz.

PINK. 30 cts. each, $\$ 3$ per doz.

"DOROTHY PERKINS." This is a splendid new shell-pink climbing Rose. It attracted much attention at the Pan-American Exposition, where a bed of fourteen-months-old plants produced a show of bloom uuequaled by any other variety. This new Rose is of the same strong habit of growth as Crimson Rambler, and the flowers are borne in clusters of 30 to 40 , and sometimes even 50 to 60 . The flowers are large for a Rose of this class, very double, sweetscented and of a beautiful shell-pink. Raised from sced of Rosa Wichuraiana and crossed with that grand old Rose, Mme. Gabriel Luizet. Absolutely hardy. The individual flower is larger than the Crimson Rambler, but it is a beautiful shell-pink in color. 30 cts. each, $\$ 3$ per doz., $\$ 25$ per 100 .

LEUCHSTERN. Introducer's description: "We received an award of merit for this beautiful variety at the Temple Flower Show in 1901, where our plants caused quite a sensation. The flowers are single, in large corymbs, bright rose with a distinct white eye; exceedingly pretty and attractive. Foliage and habit resembling Crimson Rambler, excepting that it is not quite so vigorous; it is well suited for climbing moderate distances, and for forming large bushes, pillars and pyramids in the garden." $30 \mathrm{cts}$. each, $\$ 3$ per doz.

HIAWATHA. Distinctly different from other Ramblers. Its small, single flowers-deep rubycrimson, wonderfully bright-accentuated by a white eye-are uniquely borne in long trails of 40 to 50 pips. This is a charming variety destined to become very popular among Rose lovers. Lovers of single Roses will be delighted with this variety. 30 cts. each, $\$ 3$ per doz.

ROYAL CLUSTER. Similar to Crimson Rambler, but with white, sweet-scented flowers in large clusters. $30 \mathrm{cts}$. each, $\$ 3$ per doz.

WHITE DOROTHY. Among Rambler Roses, none has justly gained greater popularity than the beautiful pink Dorothy Perkins. The White Dorothy is a duplicate, in all respects save in color, which is clear, glistening white. A decided acquisition to this class of Roses. Strong, two-year-old plants. Among the multitude of new Roses offered this is one of the few worth planting. $40 \mathrm{cts}$. each, $\$ 4$ per doz.

STANDARD CRIMSON RAMBLER. This Rose, on account of its free-flowering qualities and vigorous growth, makes a beautiful object when grown as a standard. Fine strong, plants, $6 \mathrm{ft}$. high, $\$ 1$ ea.

\section{Rosa Wichuraiana}

In some respects this Rose, which is also known as the "Memorial Rose," is better than Crimson Rambler, although it lacks the brilliant color of its more advertised contemporary. As a climber for covering porches, trellises and arches, and as a creeper for covering steep banks or any ground needing covering, it is unequaled. The foliage is a lustrous shining green. In bloom the plant is literally covered with exquisitely beautiful single white flowers, which are followed by an abundant crop of bright red heps or berries, which remain on the plant all winter. The Rose is entirely free from attacks of insects or disease, and is absolutely hardy, root and branch. Strong, 2year-old plants, 30 cts. each, $\$ 3$ per doz., $\$ 20$ per 100 ; strong, 1-yearold plants, 20 cts. each, $\$ 1.75$ per doz., $\$ 10$ per 100 .

\section{ROSA WICHURAIANA HYBRIDS}

UNIVERSAL FAVORITE. A free grower, producing longbranching shoots, with bright shiny foliage in abundance, and soft, light pink double flowers two inches in diameter; strongly perfumed. 30 cts. each, $\$ 3$ per doz.

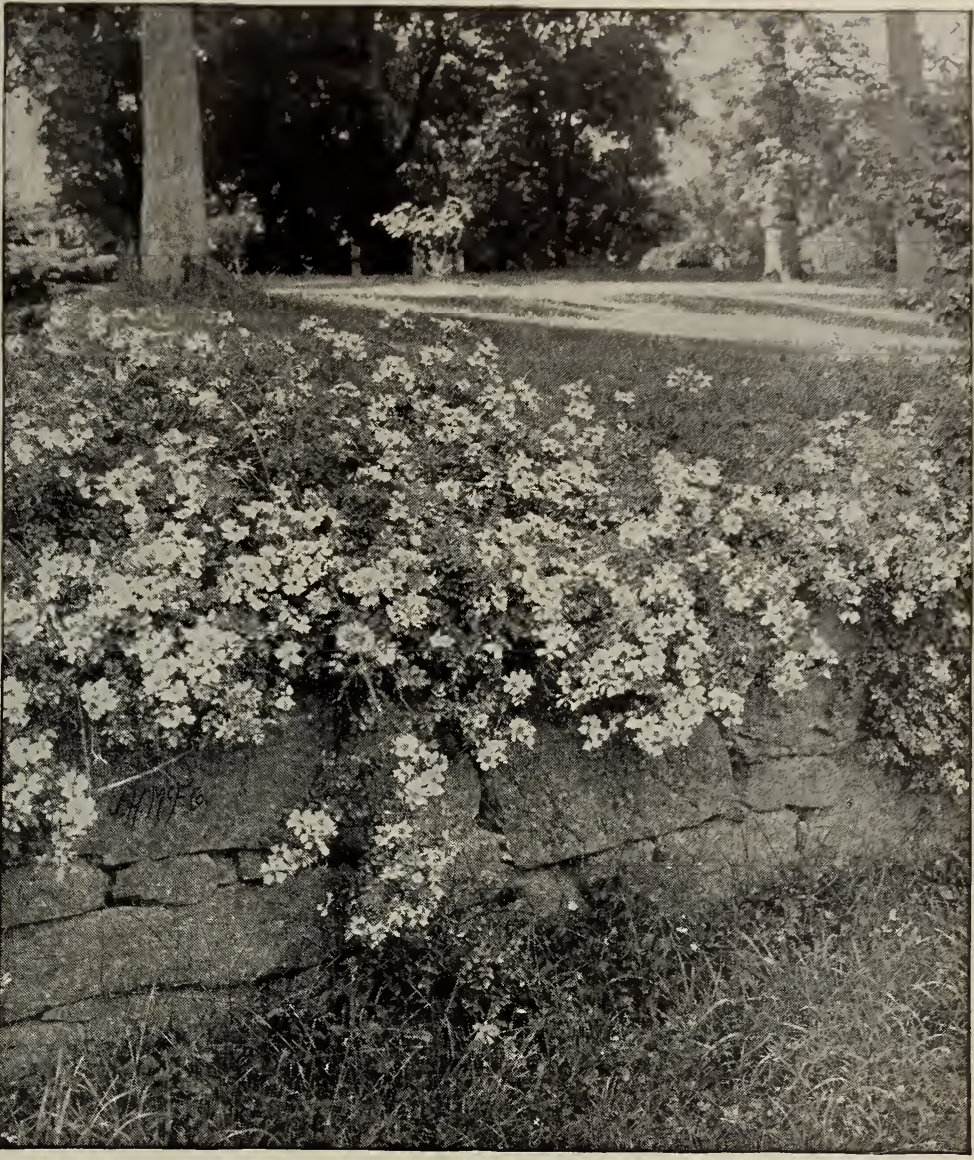

Rosa Wichuraiana covering a stone wall

Rosa Wichuraiana Hybrids, continued

SOUTH ORANGE PERFECTION. This is a gem, with free growth close to the ground, and produces multitudes of the most perfectly formed double white flowers, about one and one-half inches in diameter; soft blush-pink at the tips, changing to white. 30c. ea., $\$ 3$ per doz.

MANDA'S TRIUMPH. This is a grand hybrid of free growth with fine foliage and clusters of from twelve to eighteen flowers on even a small-sized shoot, literally covering the plant with its perfectly formed double white imbricated flowers, nearly two inches across; valuable for cut-flowers or pot-plants. $30 \mathrm{cts}$. each, $\$ 3$ per doz.

PINK ROAMER. This is without question a hybrid of the "Sweetbrier," and carries its characteristics in bloom, while the growth, which is very rampant, partakes more of the "Wichuraiana." The single flowers, which are produced in close heads, are nearly two inches in diameter, bright rich pink, with almost a white center which lightens up the orange-red stamens, producing a fine effect. 30 cts. each, $\$ 3$ per doz.

WICHURAIANA RUBRA. Long green branches; leaves medium size, glossy green; large clusters of single flowers, $1 \frac{1}{2}$ to 2 inches in diameter, bright scarlet petals tinted orange-red, white at the base, numerous orange-red stamens; flowers in June; very distinct and beautiful variety and very valuable for covering fences, pergolas, etc. $R$. Wichuraiana $\times$ Crimson Rambler. $40 \mathrm{cts}$. each, $\$ 4$ per doz

ALBERIC BARBIER. Very strong grower, with long green branches; leaves dark green, bronzy red in the spring, glossy; flowers in clusters, semi-double or double, opening well, $2 \frac{1}{2}$ to $3 \frac{1}{2}$ inches in diameter, of a nice creamy.white and canary-yellow in the middle buds of a darker yellow color; beautiful variety, tea-scented; flowers in May. $R$. Wichuraiana $\times$ Tea Shirley Hibbert. 30c. ea., $\$ 3$ per doz.

JERSEY BEAUTY (Wichuraiana $\times$ Perle des Jardins). Extremely vigorous grower; foliage shiny, thick, of leathery substance. Flowers singly or in clusters of two to four; large, single, three inches in diameter, opening pale yellow. $30 \mathrm{cts}$. each, $\$ 3$ per doz. 


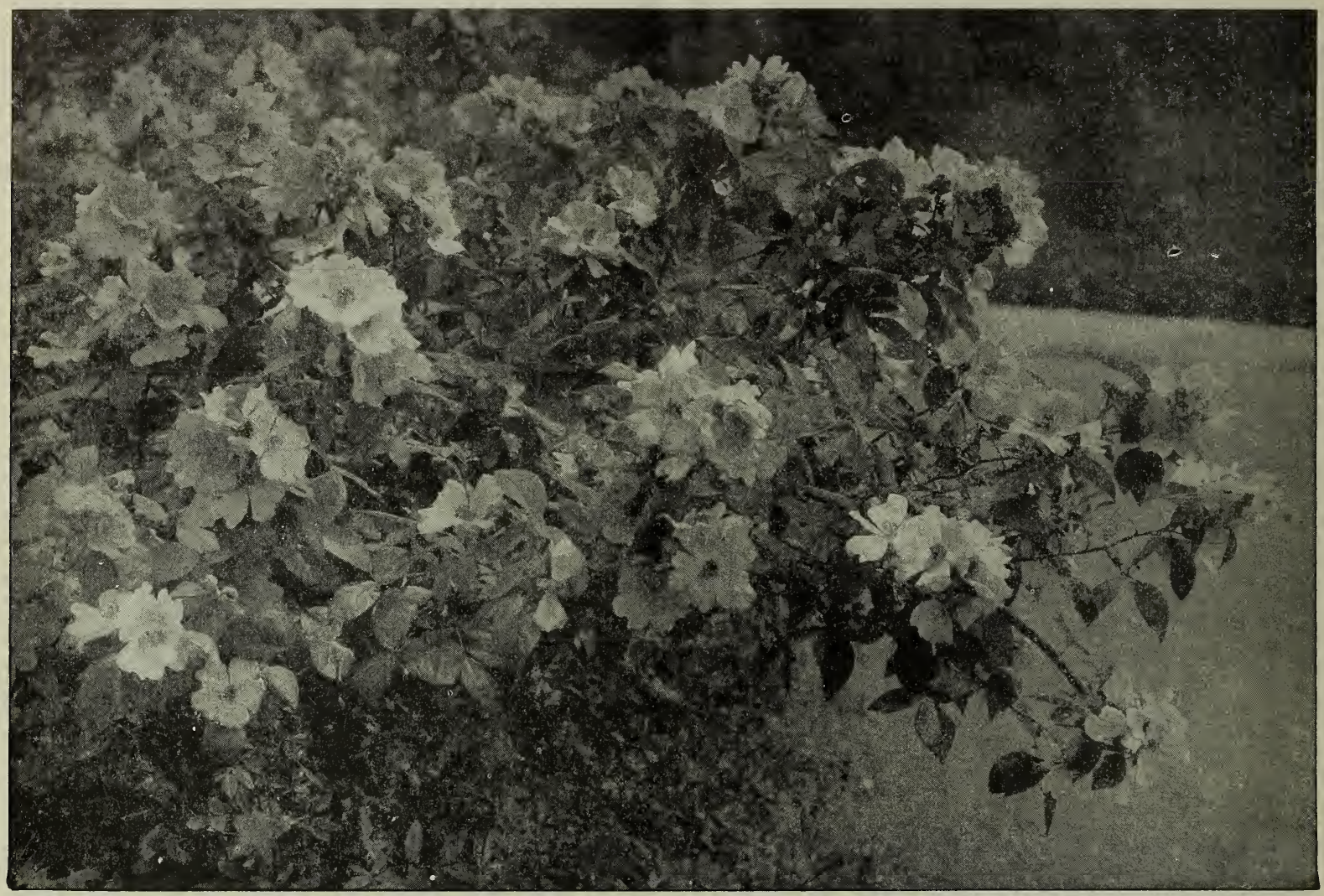

Rosa Setigera

\section{Wild Roses of Various Countries}

With the exception of the Japanese Rose, Rosa rugosa, American nurserymen have ignored the numerous wild Roses, - which is unfortunate, for they are undoubtedly the most decorative Roses that can be planted, and splendid effects are to be had with them not obtainable with any other plants; and as a rule they are of the easiest culture, vigorous growers, and entirely free from attacks of insects or disease. The flowers of all are, of course, single, but many people, of whom I am one, think single flowers more beautiful than double ones, which after all are abnormal, and the coloring, form and often the arrangement of single Roses is exquisitely beautiful. I think one of the most beautiful garden pictures I have ever seen was a trellis covered with Rosa multiflora with a border of colored peonies at the base of the trellis. Both peonies and Roses were in bloon. The Rose was literally covered with thousands of its lovely white blooms, each with a center of rich yellow stamens.

These wild Roses can be used in many ways. Some are climbers and can be used for covering anything desirable to cover with a climber; others, like Rosa Wichuraiana, are creepers, and are splendid for covering rough banks; and others are desirable for planting among shrubbery, but especially Rosa rubrifolia, Rosa rugosa and Rosa setigera. Rosa rugosa is now pretty well known, but is deserving of the greatest popularity. It has every good quality, splendid foliage, immense single red or white flowers, which bloom freely all the season and which are followed by large, beautiful red fruit, which lasts until severe freezing weather comes in winter. It should always be planted in masses either by itself or in connection with other shrubbery. It also makes a beautiful hedge.

ROSA Carolina (American Wild Rose). Each Per doz. 100

Blooms in July.................... \$0 $15 \quad \$ 150$

Lucida (Dwarf American Wild Rose)

Multiflora (Japanese). An extremely beau-

tiful Rose that can be used as a climber... $30 \quad 300$

Pomifera (The Apple Rose). Very vigorous single pink; flowers in June followed by large showy fruit, the largest produced by any Rose. 35 350

Rubrifolia. Beautiful reddish foliage contrasting well with its beautiful pink flowers; very striking and pretty in groups or planted among shrubbery.

. $30 \quad 300 \quad \$ 2000$

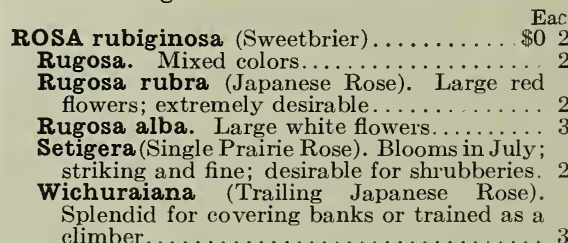

Nuttalliana

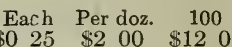

$\begin{array}{lllll}20 & 00 & -15 & 00\end{array}$

$\begin{array}{lllll}25 & 2 & 50 & 18 & 00\end{array}$

$\begin{array}{lllll}30 & 3 & 00 & 20 & 00\end{array}$

$25 \quad 250$

$30 \quad 300$

250

\section{Lord Penzance's New Hybrid Sweetbriers}

The Sweetbrier, or Eglantine, is acknowledged by all to possess one of the sweetest perfumes that nature has provided, and its delicious scent is the object for which it is usually cultivated. These new varieties are great improvements upon the old sorts. They are hybrids obtained between the common Sweetbrier and various old-fashioned garden Roses, and are possessed of the following advantages:

The flowers, which are borne in wondrous profusion, are varied in color from white, through several shades of pink, to very dark red or crimson. For vigor of growth there is scarcely anything in the Rose world equal to them. Plants three years old have now many shoots on them that rise to the height of 12 feet. 35 cts. each, $\$ 3.50$ per doz. 


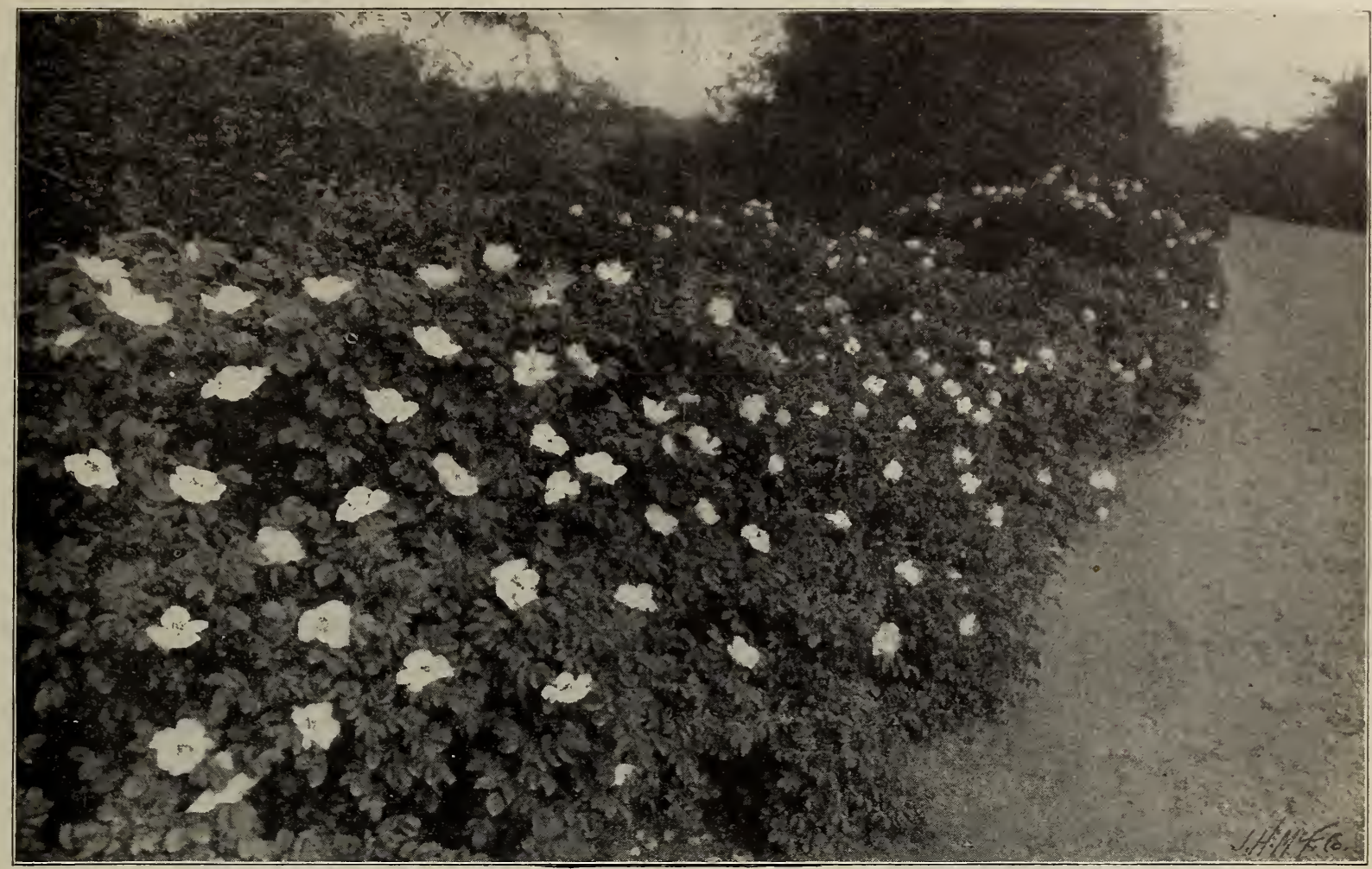

Hedge of Rugosa Roses

\section{Hedge of Rugosa Roses}

For an untrinmed hedge and for planting in masses in shrubbery, the Rugosa Roses are unsurpassed. They have the finest foliage of all Roses; their large and abundant single pink or white flowers are lovely, and the large and showy red fruit that follows the flowers makes them very attractive until severe freezing weather comes in the winter.

\section{Miscellaneous Roses}

\section{THE FOLLOWING ARE MOSTLY OLD ENGLISH GARDEN ROSES}

Electra. A cross between the single Multiflora and $W$. Each Per doz. A. Richardson. Double yellow flowers, produced in the greatest profusion..................... $\$ 0 \quad 30 \quad \$ 300$

Queen Alexandra. Large corymbs of blossoms, in way of Crimson Rambler, but paler in color.

Splendens (Ayrshire). Not a new Rose, but one of the very old-fashioned Roses revived. Strong, rampant grower, for covering banks or trees. Flesh-color; large and double

Felicite Perpetue (Sempervirens). Another oldfashioned Rose; strong grower and free bloomer; creamy white; beautiful, small and full.

Anemonæflora. Small white flowers produced in clusters and resembling white clover blossoms; vigorous growers; very distinct and dainty.

De la Grifferaie (Polyantha). Deep rose changing to blush. Double; a handsome pillar rose............

$30 \quad 300$

$30-300$

$50 \quad 500$

$30 \quad 300$

$50 \quad 500$

$50 \quad 500$
Rivers (Musk). Pink shaded with buff; double.

The Garland (Musk). Very large clusters of fawncolored buds, opening nearly white

Daniel Lacombe (Multiflora). Chamois-yellow shaded with rose.

Flora (Climbing). Rosy; flesh full

Fulgens. Deep crimson; a grand climbing Rose

Gloire des Rosomanes. Crimson; semi-double; very handsome.

vivid (Hybrid China). Vivid erimson, vey showy; a fine climbing Rose...

Damask. Old-fashioned garden rose with showy red

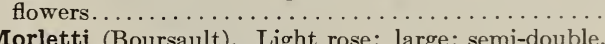

Leopondine d'Orleans (Sempervirens). Climbing Rose, white tipped with red; sniall and double..
Each Per doz. $\$ 50 \quad \$ 500$

$30 \quad 300$

$50 \quad 500$

$50 \quad 500$

$\begin{array}{llll}35 & 3 & 50\end{array}$

$50 \quad 500$

$30 \quad 300$

$50 \quad 500$

50500

$50 \quad 500$

\section{American Pillar}

A new single-flowering variety of great beauty, which appeals to every one. The flowers are of enormous size, three to four inches across, of a lovely shade of pink, with a cluster of yellow stamens. These flowers are borne in immense clusters, and a large plant in full bloom is a sight not easily forgotten. They last in perfection a long time, and are followed by brilliant red hips or berries, which are carried late into the winter; and as the plant frequently retains its lovely green foliage until the end of November, it forms a beautiful decorative subject throughcut the autumn months. Strong two-year-old plants, $75 \mathrm{cts}$. each; $\$ 7.50$ per doz. 


\section{Dahlias}

The following varieties of Dahlias are a selection made from the stock of the most famous Dahlia specialist in the world, and are unques. tionably the best varieties introduced to date. The prices quoted are for good strong roots. In May we can supply pot-grown plants from cuttings at a discount of 25 per cent from these prices.

\section{Newer Dahlias}

20TH CENTURY. Also known as the orchid-flowered single Dahlia. Intense rosy crimson with white tips, and white disc around the yellow center. As the season advances, the dark-colored zone becomes lighter; flowers 4 to 6 inches in diameter, exquisitely beautiful. 20 cts. each, $\$ 2$ per doz.

PINK DANDY. A pure pink double show Dahlia, of large size and form. Plant strong and vigorous. $25 \mathrm{cts}$. each, $\$ 2.50$ per doz.

ELOISE. A charming double variety and very distinct. The ground color is blush-pink shading to white. Each petal is margined with deep glowing crimson. $20 \mathrm{cts}$. each, $\$ 2$ per doz.

OL YMPIA (Double). One of the grandest fancy Dahlias to date The flowers are of immense size, rose-pink, striped and penciled with rich crimson. 25 cts. each, $\$ 2.50$ per doz.

EUREKA (Double). One of the most valuable Dahlias yet produced, both as a blooming plant and for cut-flowers. The flowers are large to very large, of deep rose-color and fine regular form; quilled petals and perfectly full to center. $20 \mathrm{cts}$. each, $\$ 2$ per doz.

FRANK L. BASSET (Double). Bright royal purple, shading to blue. The nearest approach to a blue Dahlia yet produced. Very free bloomer and fine for cutting. One of the best decorative Dahlias yet produced. $20 \mathrm{cts}$. each, $\$ 2$ per doz.

BRIDESMAID (Cactus). Pale primrose, shading to delicate rose toward the outer petals; beautiful form and free. $20 \mathrm{cts}$. each $\$ 2$ per doz.

CAPSTAN (Cactus). Soft, brick-red, shaded apricot. Remarkable for its free and early flowering. $15 \mathrm{cts}$. each, $\$ 1.50$ per doz.

KONIGEN WILHELMINA (Cactus). Deep crimson, richly shaded; fine form; a free and continuous bloomer. 20 cts. each, $\$ 2$ per doz.

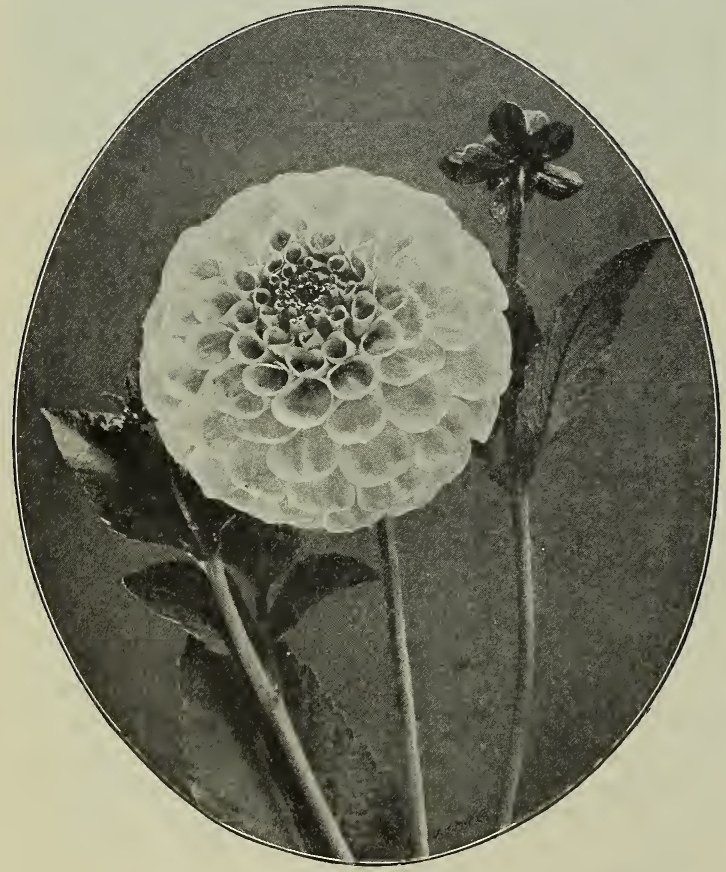

Double Show Dahlia

\section{Cactus Dahlias}

20 cts. each, $\$ 2$ per doz.

Bertha Mauley. Scarlet, overlaid crimson-purple.

Blanch Keith. Beautiful pure yellow of largest size,

Cycle. Bright rosy crimson; early and profuse.
Cactus Dahlias, continued

Geo. Marlow. Primrose-yellow, shaded amber.

Henry Stredwick. Rich velvety maroon; petals long and narrow. An exquisite flower.

Miss A. Nightingale. Large, deep yellow, heavily tipped bright red fine combination; semi-double.

Purity. Pure white, medium size; splendid form; very fine.

Miss Grace Cook. Deep rose-color; with pearly white tips.

Kriemhilde. The finest of all pink Cactus Dahlias.

\section{Decorative Dahlias (Double)}

20 cts. each, $\$ 2$ per doz.

Admiral Dewey. Brilliant imperial purple. Of fine form; a strong grower, and by far the best of its class.

Clifford W. Bruton. The best yellow; of immense size, perfect form, and one of the finest of its color. A tall, vigorous grower and extremely free bloomer. Should be in every collection.

Maid of Kent. Cherry-red, tipped white; sometimes a solid color, when it is superb red.

Mrs. Geo. Reed. Pure white, beautifully edged and flaked soft rosy lake; the petals overlap each other, and are deeply cleft.

Nymphæa. By far the most delicately beautiful Dahlia ever introduced; extensively grown for cut-flowers. The flowers are of medium to large size, always full to the center, resembling the ideal pink water-lily. The color is a clear, distinct, light shrimp pink, tinted lighter toward the center.

Zulu. Rightly named "the Black Dahlia." Jet-black, changing to black-maroon as the flowers fully expand. - Of fine form and full to the center.

\section{Show Dahlias (Double)}

\section{0 ets. each, $\$ 2$ per doz.}

A. D. Livoni. Beautiful soft pink, with quilled petals and full to the center; an early and profuse bloomer.

Arabella. Very fine form; pale primrose, tipped and shaded old-rose and lavender.

Armorer. Deep red dwarf and a profuse bloomer.

Emily Edwards. White, suffused pink; beautiful.

Glowing Coal. Bright glowing crimson.

Hero. Deep crimson-maroon; large, full to the center and profuse bloomer.

Mrs. Dexter. Large; a rich shade of salmon; best of its color.

Psyche. Pale primrose, shaded rose; a dwarf branching plant, and one of the most profuse bloomers.

Paul's Scarlet. Brightest scarlet.

Queen Victoria. Deep yellow; finely quilled.

Snow. Snow-white; profuse bloomer.

Sport. A pure lavender sport of Penelope.

\section{Fancy Dahlias (Double)}

\author{
20 cts. each, \$2 per doz.
}

Elegans. Rosy purple, tipped and banded white; quilled petals.

Fern-leaved Beauty. Beautiful fern-leaved sort; white, striped deep crimson.

Keystone. Pink, striped crimson; large, fine.

Leiberheimer. Crimson, striped white.

\section{Single Dahlias}

A collection of the best named varieties. $15 \mathrm{cts}$. each, $\$ 1.50$ per doz

\section{Mixed Dahlias}

The following Dahlias are all seedlings of our own growing. They the following and produced just as fine flowers as named varieties.

Single............................. Per doz. $\$ 100$ 


\section{INDEX}

Abies.............9, 60 Aracia, Rose-flowered......57 cer $\ldots \ldots \ldots \ldots \ldots \ldots \ldots \ldots, 15,59$ Achillea.............. 44 Actinidia.............10, 42 Aconitum................. Agrostemma............4 Alianthus................... Akebia.................. Alder..................... 58 Almond............51, 59 Alstræmeria $\ldots \ldots \ldots \ldots \ldots \ldots, 40$ Althæa $\ldots . \ldots \ldots \ldots \ldots \ldots \ldots \ldots .64$

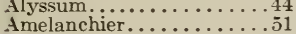

Amelanchier.............. zpelopsis...........42 schusa................ ndromeda........... $51, \overline{5}$ inemone.............. 74 inthemis...............44 Iquilegias......... $8,31,32,44$ trabis.................44 ra lia.................44, 51 Arenaria..................... Aristolochia................42 Armeria ..............32, 44 Arrhenatherum ..........44 Artemisia............39, 44 Artichoke, Jerusalem......48 Asclepias...................44 Ash............... $31,38,59$
Asters........ 34,46 Aster, Stokes'...........32 Aubrietia..............46 Avens........... Baby's Breath............48 Bachelor's Button....... 50 Balm of Gilead.........58, 59 Baptisia................... Barberry............. 53,60 Barrenwort..............36

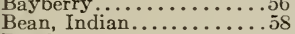
Beech,................. 58 Bellflower...............46 Bellis............... 31,46 Berchemia................42
Bergamot..............49 Bergamot...............49 Biota .................60

Birch

Bittersweet............. Blue Bells................. 39

Bocconia...............46

Books and Papers, Garden-

ing.................. 16

Box Eider..................

Broom.................39, 54

Buckthorn.............54, 56

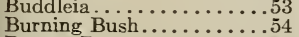

Button Bush ................

Calimeris....................

Calycanthus................

Campanula $\ldots \ldots \ldots \ldots \ldots \ldots . .46$

c ndytuft.

C rbury Bells........46, 47 Ca yopteris................. Cassia ............... Catchfly, Alpine............5 50 Ceanothus.............. Celastrus................ 15,42 Centaurea................ 47

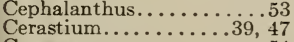
Cerasus.

Cercis..................... 58 Chaste Shrub........... 57 Cherry Flowering........... 58 Chestnuts................59

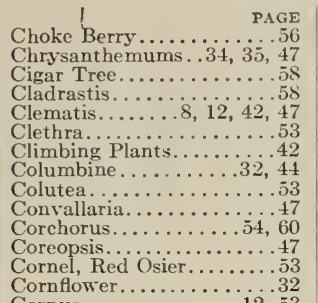

Cornflower...............

Coronilla................ 31,47

Corylus.

Cowslip.

Crab Apple.

Crambe

Cranberry Tree.

Cratægus.

Cucumber Tree...

Currant, Indian.

Currant, Missouri

Cydonia

Cypripedium.

Cytisus.

Daisy, Doubi

Daisy, Double English......3

Daisy, English

Daisy, Globe..............

Daphne.

Deciduous Trees........ 58,59 Delphiniums.........29, 47

Deutzia................... 54

Dianthus........... 35, 47

Dicentra................47

Diervilla.................... 54

Dogwoods...........12, 53, 58

Dolichos................... 42

Doronicum.

Dracocephalum........

Dutchman's Pipe............42

Echinops................4. 47

Edelweiss................

Elæagnus................

Elm..................5s

Epilobium.................47

Epimedium ................. 36

Erianthus. ...

Eryngium

Eulalia $\ldots \ldots \ldots \ldots \ldots, 47$

Euonymus......... 42,54

Eupatorium...............48

Euphorbia.............48

Evergreens, for Trans-..

planting............... 9

Exochorda...............

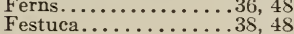

Fir................

Flax................... 49

Forget-me-not, Water.....49

Forsythia............

Fringe, Purple.........

Fringe, White.

Funkia.................

Genista...............39, 48

Gentiana.................. 48

Geum..................

Gillenia

Gingko.

Globularia............. 18

Gloxinia, Hardy ........ 10, 49

Golden Bell .............5

Golden Chain............54

Grape, Wild.............38, 42

Gymnocladus.............. 58

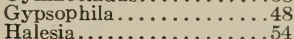

Hamamelis................ 54

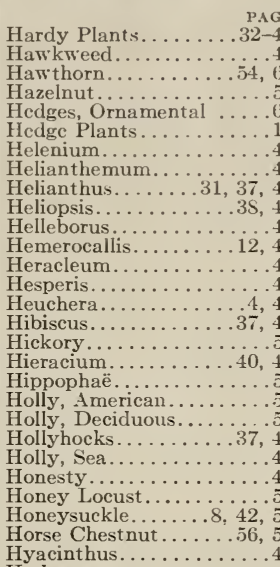

Hyacinthus...

$4,7,8,14,17,40,54$

Hypericum.

Iberi.

Incarviliea.....

Indigo, False.

Inula ................ 51

Iris..... $8,26-28,38,48,49$

Ivies, English.

Jacob's Ladder

Judas Tree

Juniper.

Juniperu .

Kentucky Coffee Tr...15, 5s

Kerria.

Knapwood, jiountain.......47

Knotweed, Giart

Kaburnum.

Larch..........

Lathyrus.

Lathyrus .........

Lavender.

Lawns from Seed

Leontopodium . .

Leucoth

Ligustrum..........

Lilacs............ is, $\overline{5}$, 60

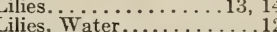

Lily, Blackberry........... 49

Lily, Blue Day....

Lily, Chilian.

Lily, Lemon Day.

Lily-of-the-Valley

Lily, Orange Day

Lily, Torch

Lily, White Day.

Linden

Linum...........

Liriodendron

Lobelia...

Loosestrife............

Lotus, Egyptian............ 12

Lupinus................

Lychnis.................

Lycium $\ldots \ldots \ldots \ldots \ldots \ldots \ldots .42$

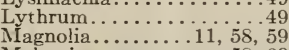

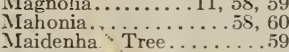

IIaidenha Tree......... 59

Mallow iIarvis, ifeehan's 4

Malva.

Iaple.

Maples, Japant e...........

Matrimony Yin $\ldots \ldots \ldots \ldots+42$

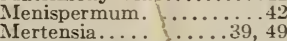

Mock Oiange.

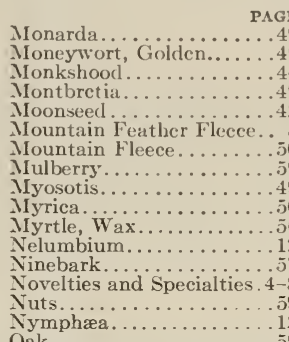

Oak

Enothera

Old Wran.....

Onopordon

Osier, Red. ...

Pronia

Pansies, Tufted

Papaver.

Phloxes, Perennial.

Pardanthus

Parsnip, Gia

Pavia.

Pearh Bush

Pea, Siberian...............

Pentstemon ...

Peonies ..........20-25, 49

Pepper, Sweet......... 43

Periploca.

Persimmon.

Phlox, $\ldots 6,31,34,41,49$

Photinia.

Physostegia.

Picea. Austrian.
Pine, Sea.....
Pink,

Plants for Naturalizing.

Platycodon.

Plumbago...

Plum, Flowering.

Plum, Purple-leaved....56, 53

Polemonium.
Polyanthus..

Polygonum.....12, $40,42,50$

Poplar................. 49

Potentilla ...............56

Primrose, Hardy English

Primroses............. 35

Primula $\ldots \ldots \ldots \ldots \ldots \ldots, 5,50$

Privet, Amoor.

$11,56,5$

Prunus............ $11,56,59$

Pyrus................ 56,58

Quercus.................

Ragged Robin..........

Ranunculus ............

Red Bud

Red-hot Poker

Retinospora...

Rhamn

Rhoudodendron...... $15,20,58$

Rhodora...

Rhodotypus............ 56

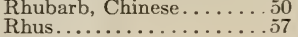

Ribes.

Robinia

Rocket, Sweet.

Rockfoil..............

Rose, Christmas.

Rose of Sharo

Rosemary.............

Roses ....6, 7, 11, 15, (60-65

Rubus...............14, 57

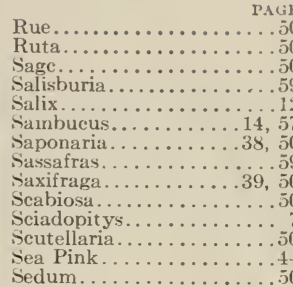

Senna, Bladder

Senna, Wil

Shellbark..........

Shrubs, Flowering..
Shrub, Sweet-scented

silene...

Silphium.

Silver Bell
Snowball

Snowberry

Snowflower, Alpine

Snow-in-Summer

Sorrel Tree.

Southernwood.

Spanish Bayonet

Spiræa

Spirea, Blue

(3)

Spruce................. 9,60

Spruce, Weeping Blue..
Stachys.

Stachys...

Statice.

Stenanthium.

Stephanandra

Stuartia

Styrax 


\title{
A PLEA FOR HARDY PLANTS
}

\section{By J. WILKINSON ELLIOTT}

TENDER plants predominate in so many modern gardens that lovers of flowers should be 1 grateful to Mr. J. Wilkinson Elliott for bringing forth an argument, in the shape of a sensible and practical book, in favor of our native asters, lilies, hollyhocks and other hardy plants. This book is sure to appeal to all garden makers.

\section{PRESS COMMENTS}

"Certainly one of the most sensible as well as beautifully illustrated nature books that the season has to offer."-Chicago Record-Herald.

"Such a book is an inspiration to the inert land-owner, and has real help to offer the energetic one."-Farm, Field and Fireside.
"An irresistible combination of sensible suggestions and splendid illustrations."-Los Angeles Herald.

"The price is incredibly small considering the mechanical perfection of the book."-Nashille American.

"Should be in the hands of every owner of a country place." - The Argonaut.

PRACTICAL AND WELL ILLUSTRATED NEW AND ENLARGED EDITION. PRICE, NET, \$1.60

DOUBledAY, PAGE \& CO., Publishers, 133-137 East Sixteenth St., New York

\section{SPECIAL OFFER}

We should like very much to have every one of our customers receive a copy of the book advertised above, and with this end in view we have made arrangements with the publishers by which we can supply our customers with it at a nominal price. With orders for trees, shrubs, plants or bulbs amounting to two dollars or more, a copy of the book bound in cloth may be added for seventy-five cents, but only one copy can be ordered at this price, or every one who sends to us a subscription to that splendidly illustrated magazine, "Country Life in America," will receive a copy of the book, "A Plea for Hardy Plants," free of cost ; or, in other words, the magazine and the book will be sent for the price of the magazine alone, which is four dollars per year.

\section{ELLIOTT NURSERY}

\section{LANDSCAPE GARDENING}

TПHE majority of American suburban grounds are laid out and planted without the aid of professional advice. The result is almost always unsatisfactory, although often the expenditure would have secured most beautiful results if directed by skilled advice. I do landscape gardening-do it for people of exacting taste, to whom I refer. I make the plans, with estimates, purchase the stock necessary and superintend the work. I do any one or all these things, satisfactorily as to results, moderately as to cost. For small grounds I can make satisfactory plans if furnished with a plat drawn to seale. For large grounds, and where extensive inoprovements are desired, a personal visit would be necessary and can be arranged for on reasonable terms. I can make no plans during the month of April.

\section{J. WILKINSON ELLIOTT}

\author{
LANDSCAPE RCHITECT \\ Magee Building, 336 Fourth Avenue PITTSBURG, PENNSYLVANIA
}

